Török Bernát

\title{
A SZÓLÁSSZABADSÁG MAGYAR DOKTRÍNÁJA AZ AMERIKAI JOGIRODALOM TÜKRÉBEN
}

Doktori $(\mathrm{PhD})$ értekezés

Szeged

2018 
Szegedi Tudományegyetem

Állam- és Jogtudományi Kar

Doktori Iskola

Török Bernát

\section{A SZÓLÁSSZABADSÁG MAGYAR DOKTRÍNÁJA AZ AMERIKAI} JOGIRODALOM TÜKRÉBEN

Doktori $(\mathrm{PhD})$ értekezés

Témavezetők:

Dr. Paczolay Péter egyetemi tanár, SZTE ÁJTK

Dr. Majtényi László egyetemi tanár, ME ÁJK

Szeged

2018 


\section{TARTALOMJEGYZÉK}

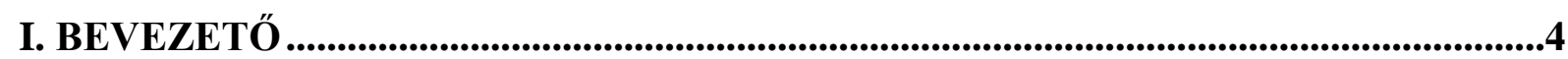

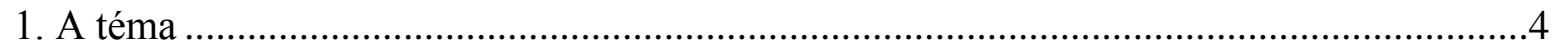

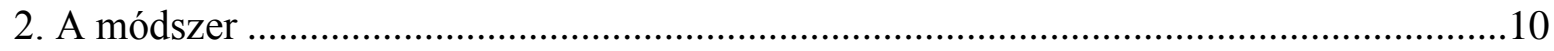

II. A KÖZLÉSEK ALKOTMÁNYOS ALAPÉRTÉKE.......................................................17

1. Hatály és védelem elhatárolása a szólásszabadság doktrínájában .................................18

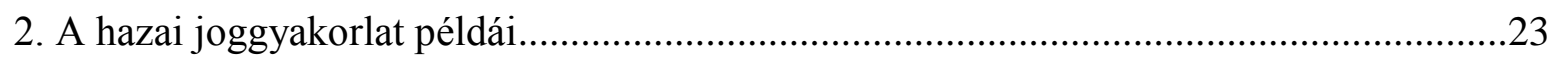

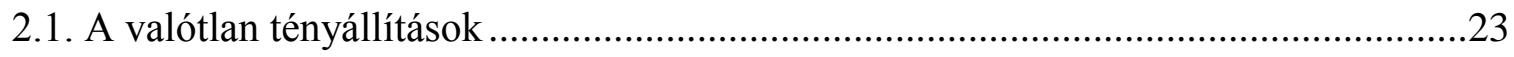

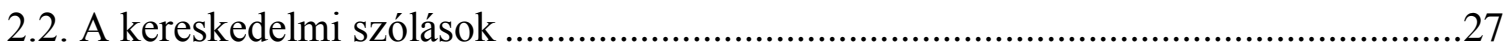

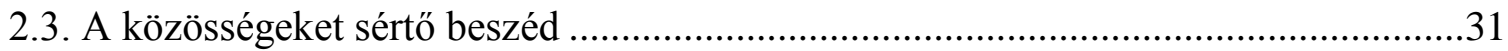

3. A szólásszabadság hatályának magyar koncepciója ....................................................35

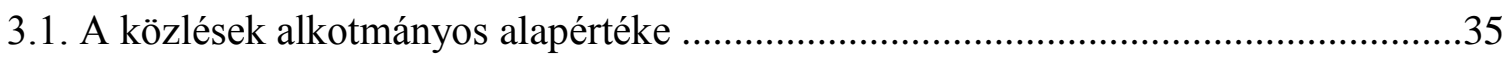

3.2. A társadalmi kommunikációban való részvétel mint megkülönböztető jegy ..............39

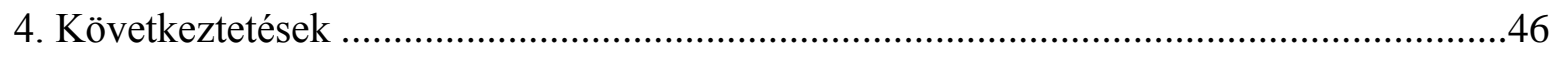

III. A KÖZÜGYEK VITÁJÁNAK KÖRVONALAI..............................................................47

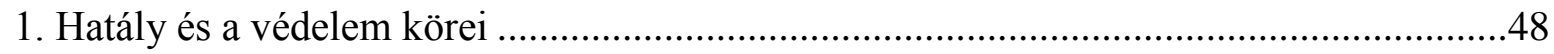

1.1. A demokrácia alapú elméletek megközelítése.....................................................48

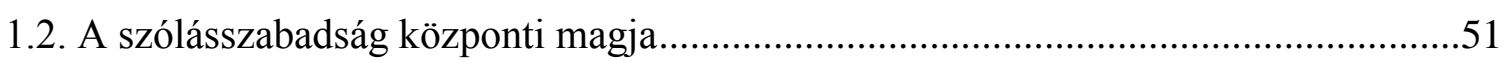

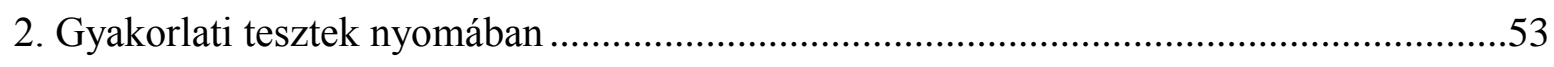

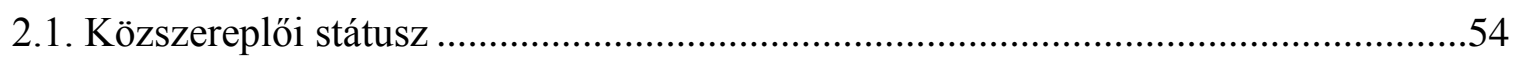

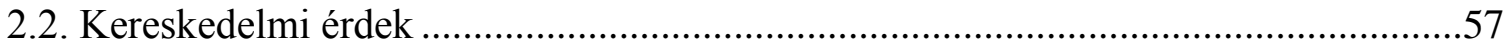

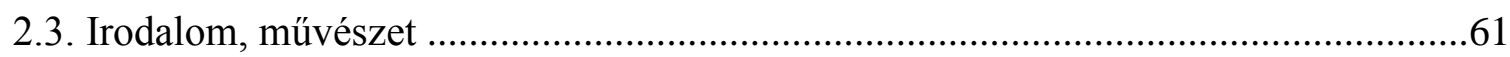

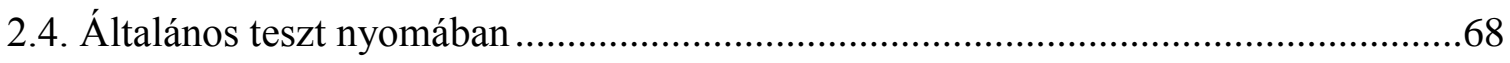

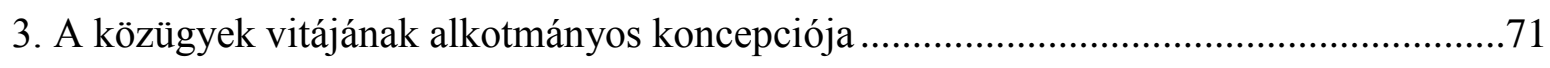

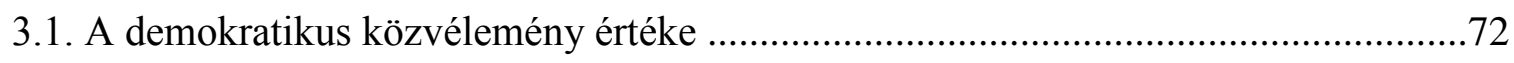

3.2. A releváns érték helyes azonosítása a gyakorlat példáin ......................................... 80

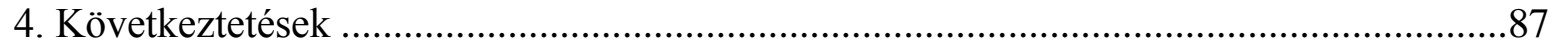

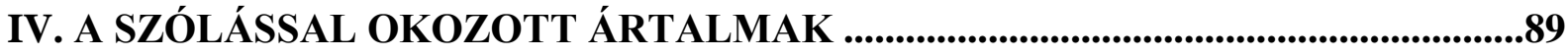

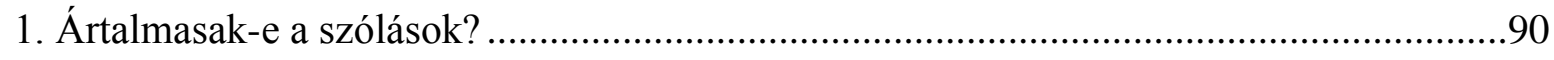

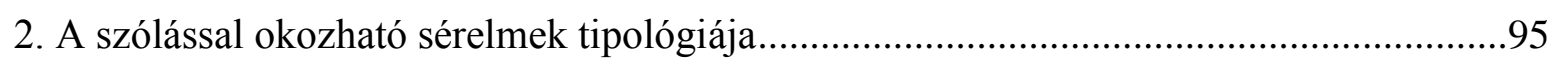

3. Az ártalmak értékelésének alaptételei a magyar doktrínában ....................................102

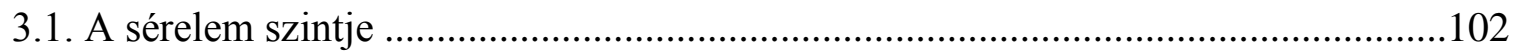


3.1.1. A szólás és veszélyes következménye (uszítás és rémhírterjesztés)...................104

3.1.2. A bántó szavak: a közösségeket sértő beszéd ………........................................112

3.2. A sérelem értékelésének alapszemlélete: a szólás joga ........................................124

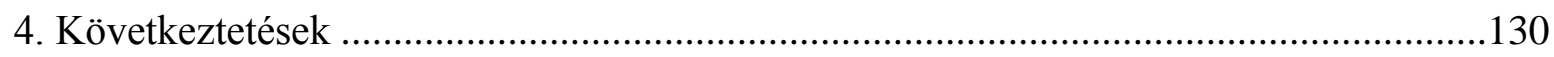

\section{A SZÓLÁSKORLÁTOK TARTALOMSEMLEGESSÉGÉNEK}

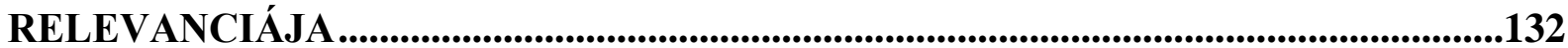

1. Elméleti keretek a tartalomsemlegesség megragadásához .........................................134

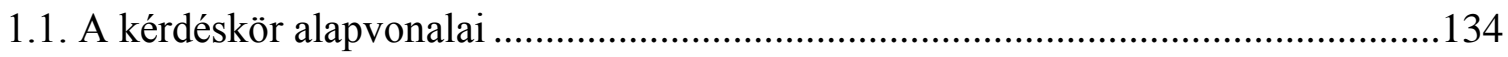

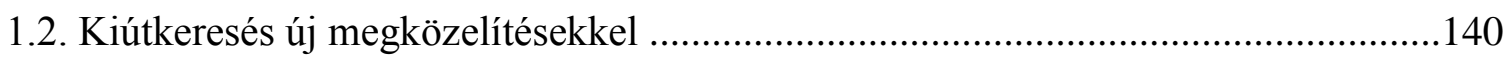

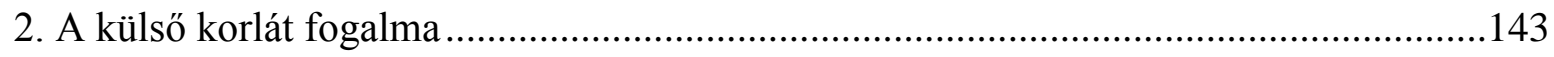

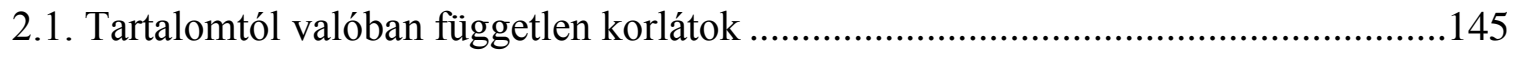

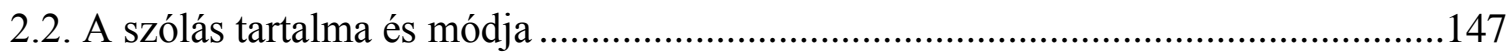

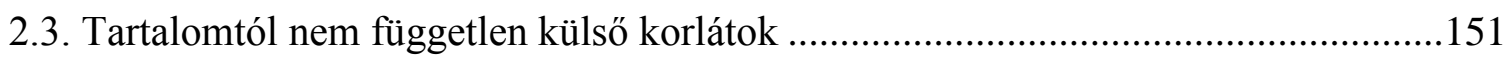

3. A tartalomsemlegesség érvényes tételeinek tisztázása............................................154

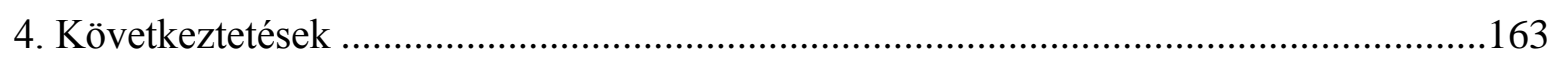

VI. A SZÓLÁSSZABADSÁG VÉDELMÉNEK DINAMIKÁJA......................................165

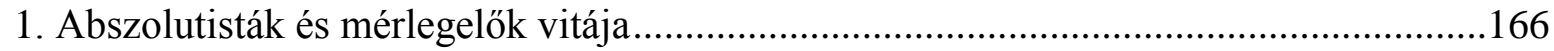

2. A dilemma létjogosultsága a magyar dogmatikában...............................................174

3. A szabadabb mérlegeléstől az alaptörvény-ellenesség vélelméig .................................180

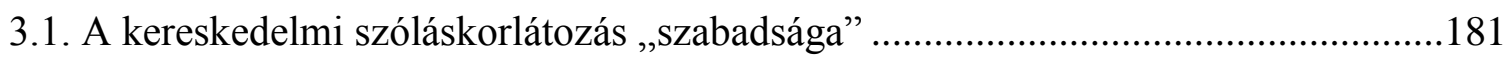

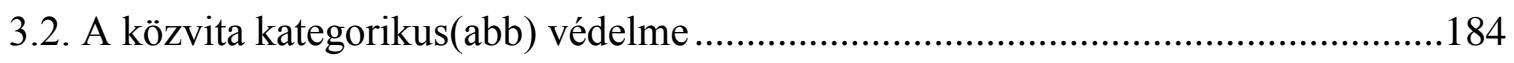

3.2.1. Megforduló vélelem a szólás szabadsága mellett .........................................184

3.2.2. Jogági különbségek relativizálódása...............................................................191

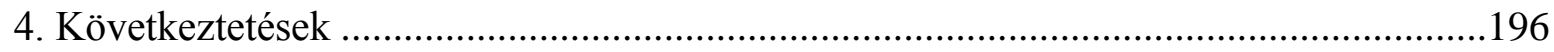

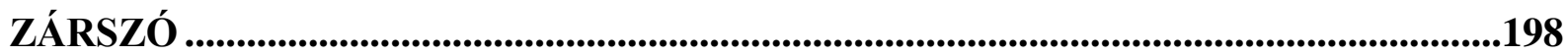

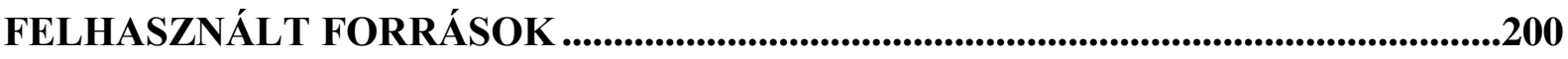

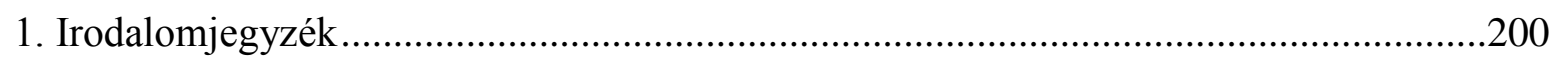

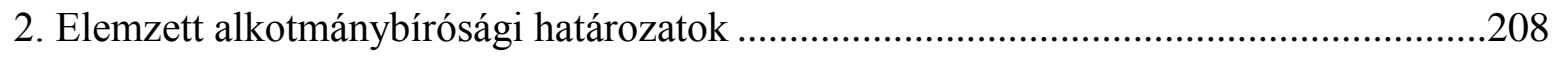




\section{BEVEZETŐ}

\section{A téma}

Ez az értekezés a szólásszabadság magyar doktrínájának alapjait igyekszik tisztázni. ${ }^{1}$ Teszi ezt speciális, érdemi magyarázatot kívánó módszer alkalmazásával, és erre a magyarázatra rögtön rá is térek, elötte azonban pár gondolat arról, hogyan is jutottam erre a témára, és miben láttam munkám célját. Amikor az ember fiatal kutatóként a véleménynyilvánítás jogának vizsgálatára szegődik, természetes módon vonzzák figyelmét a kérdéskör nagy klasszikus témái, amelyekről a szólásszabadság modern, demokratikus doktrínájának megszületése óta hallatlanul izgalmas jogi, társadalmi, kulturális párbeszéd zajlik. Gyülöletbeszéd, emberi méltóság védelme, blaszfémia, közerkölcs védelme, becsületsértés, káros médiatartalmak szabályozása folytathatnánk a sort a kommunikáció szabályozásának számos érdekes és nemegyszer szenvedélyes vitát kavaró problémájával. Ezek a problémák nemcsak a tradíció felől nézve tünnek fel klasszikusként, hanem abban az értelemben is, hogy a mögöttük húzódó társadalmi, kulturális kérdések újból és újból kihívás elé állítanak minket. Magától értetődőnek tartom, hogy napjaink jogtudományának is különösen izgalmas témái ezek. Hasonlóképpen nyilvánvaló, hogy a nagy klasszikusok mellett egyre több

\footnotetext{
${ }^{1}$ A dolgozat - miként címe is jelzi - a vizsgált alapjog megnevezésére elsődlegesen a „,szólásszabadság” terminussal él, miközben - nem utolsósorban a borzasztóan zavaró folyamatos szóismétlések elkerülése érdekében - ennek egyenértékü megfelelöjeként használja a „,véleményszabadság”, illetve „a véleménynyilvánítás-”, ,a közlés-” vagy „,a kifejezés szabadsága” megjelölést is. Ezzel a terminológiai sokszínüséggel azok mérvadó táborához csatlakozom, akik nem tulajdonítanak sem elvi, sem gyakorlati jelentőséget a kifejezések különbözőségének, és egymás szinonimájaként használják őket. Vö. pl. SAJÓ András: A szólásszabadság kézikönyve. Budapest, MTA Állam- és Jogtudományi Intézet, 2005; HALMAI Gábor: A véleményszabadság határai. Budapest, Atlantisz, 1994; KOLTAY András: A véleménynyilvánitás szabadsága. Fogalmi tisztázás az Alkotmány 61. §-ához. Századvég 2008/2. 77-78.; hasonlóan lásd erről pl. Eric BARENDT: Freedom of Speech. Oxford-New York, Oxford University Press, 2005. 75. A többféle terminus közötti választáshoz nem találunk perdöntö érvet, és bármelyik kifejezéssel szemben felhozhatók szempontok, így jelentős részben egyéni ízlés kérdése, ki melyiket részesíti előnyben. Több okból sem tartom perdöntőnek azt, hogy a hazai alkotmányszöveg 1989 óta a „véleménynyilvánítás szabadságáról” szól: egyrészt maga az Alkotmánybíróság is mindvégig megtartotta a „szólásszabadság” elnevezést is, másrészt éppen ez az a kifejezés, amely az összes közül a legtöbb sebböl vérzik (a ,véleményekre” mint értékítéletekre való utalása például kifejezetten félrevezető a magyar nyelvben, és megtévesztő a tényállításokról való gondolkodás kapcsán). A „szólásszabadság” angolszász eredetű, míg a „véleményszabadság” és a „véleménynyilvánítás szabadsága" kifejezéseket a német terminológia ihlette, az elöbbi már csak ez okból is jobban illik dolgozatom megközelítéséhez. Emellett azért is a „szólásszabadság” áll közelebb a szívemhez, mert ízesebb kifejezésnek érzem társainál, és a magyar nyelvi hagyományhoz is ez illeszkedik leginkább. Választásom így összességében magától értetődő volt, annak ellenére, hogy - ha nagyon akarom dogmatikai szempontból a „közlés-” vagy a „kifejezés szabadságát” tartom a legpontosabbnak.
} 
új, a digitális kommunikáció forradalmával berobbanó kérdés is feszíti a véleményszabadság ügyét: az új digitális platformok, az internetes kommunikáció számtalan formája, a kommentelés, a keresőmotorok tevékenysége, illetve a közösségi média kérdései csak a legismertebbek a legújabb kor kihívásai közül.

És mégis, ez a dolgozat sem a nagy klasszikusok, sem a sürgető új témák közül nem fókuszál önmagában egyikre sem. Sok részkérdés felbukkan persze - egyik-másik néhol kifejezetten fontos szerephez is jut az érvelésben -, de vállalkozásom lényege nem a véleménynyilvánítás valamely specifikus témájának kibontása. Tapasztalatommá vált ugyanis, hogy minél jobban keresi az ember a konkrét problémákra adandó válaszokat, annál inkább az válik perdöntővé, tisztázta-e a szólásszabadság doktrínájának horizontális, azaz valamennyi téma számára releváns kereteket nyújtó alapjait. Mindenekelőtt a tartópilléreket kell a helyükre tenni, hogy azután rájuk lehessen építeni a speciális kérdésekre kifuttatott érveket. E nélkül nem maradna más, mint kidolgozatlan formulákként dobálózni olyan alapvető szempontokkal, amelyeknek konkrét, gyakorlati megoldásaink lényegi magját kell(ene) adniuk. Ezeknek a megoldásoknak az igazolhatósága ugyanis- az adott probléma 21. századi megértése mellett - meghatározó részben végül kidolgozójuk helyes (vagy ellenkezőleg: nem-értő) szemléletén múlnak. A jogász számára az adekvát hozzáállás kérdése nem lehet szubjektív intuíciók függvénye, hanem a doktrína alapkérdéseinek tisztázásán kell nyugodnia. Hogy ez a dolgozat miként kívánja segíteni ezt a tisztázást, azt az alábbi három pontban elővételezem.

a) A dolgozat a szólásszabadság jogával foglalkozik. Nem szenvtelenül teszi ezt, hanem abból a meggyőződésből, hogy a véleménynyilvánítás kérdései mindig túlmutatnak önmagukon: egy társadalom életének adják látleletét. A véleményszabadságot vizsgálva demokráciánk állapotáról, minőségéről, jellemzőiről kapunk képet. Az Alkotmánybíróság szavaival: „[a] szólás szabadságának állapota a demokrácia fokmérője."2 A nyugati civilizáció jó ideje elkötelezettje a szabad véleménynyilvánítás jogának. Felismerte, hogy az egyéni szabadságnak és a demokratikus közösség boldogulásának nélkülözhetetlen fundamentuma a gondolatok, nézetek közlésének kötetlensége. A véleménynyilvánítás határait keresve saját

\footnotetext{
${ }^{2}$ 18/2004. (V. 25.) AB határozat, Indokolás II.1.1., ABH 2004, 303, 305.
} 
magunkról mint társadalomról, demokratikus közösségről is újból és újból megfogalmazzuk alapvető gondolatainkat. ${ }^{3}$

Ebből a meggyőződésből fakadóan a dolgozat a szólás szabadságának elkötelezettjeként kíván érvelni. Ez semmiképp nem jelent elvakultságot, hiszen az magának a véleményszabadságnak sem állna érdekében: a körülöttünk lévő valóság összetettségének figyelembevétele nélkül nem juthatunk hiteles és másokat is meggyőző megoldásra - márpedig e nélkül mégoly magasztos elveink és szépen hangzó gondolataink is öncélú, terméketlen okoskodás maradnak. Az azonban már szilárd meggyőződésem, hogy a valamennyiünk és a közjó érdekét is szolgáló szabadság ez esetben azt kívánja meg, hogy az összetett valóság körülményeinek mérlegelésekor „hüvelykujjunkat a véleménynyilvánítás jogának serpenyőjén tartsuk". 4 Nem azért, hogy minden esetben a mérlegelés győzteseként hozhassuk ki, hanem azért, mert e nélkül jóval többször maradna alul, mint ahányszor azt alkotmányos céljaink elérése szempontjából megengedhetnénk magunknak. Lássuk be: a szólásszabadsággal konkuráló érdekek nagyon sokszor több (és tömegesebb) empátiát vagy szenvedélyt képesek ébreszteni, mint a megszólalás értékessége melletti érvek. Ráadásul ha ehhez még hozzátesszük a kommunikációba beavatkozó állam állandó kísértését, hogy abban az esetben is felhívja ezeket az átélhető szempontokat, amikor egyébként valójában teljesen más szándékok vezérlik, akkor különösen egyértelmü, hogy a jogi válaszok terén e „korrigáló” szemlélet nélkül villámgyorsan elfogyna a levegő a véleményszabadság körül.

E helyütt érdemes tisztáznom, hogy a dolgozat a szólásszabadságra alapvetően nem mint kommunikációs anyajogra, hanem mint önálló alapjogra fókuszál. Ahol mégis megjelennek az érvelésben elsődlegesen más kommunikációs jogokhoz (például a gyülekezési joghoz) kötődő elemek, ott annak szerepe mindig arra szorítkozik, hogy a véleménynyilvánítás joga számára fontos tanulságokat levonhassuk. Így van ez annak a jognak az esetében is, amelyre a szólásszabadsággal meglévő különös kapcsolata miatt sok utalás történik: a sajtószabadság markánsabb jelenlétének sem az az oka, hogy a hozzá kötődő önálló dogmatikai kérdéseket, például a médiaszabályozás

\footnotetext{
3 Tóth Gábor Attila idevágó érvelése szerint „a szólásszabadság minden értelmezése morális értelmezés.” Nem azt értve ez alatt, hogy a szólásszabadsággal kapcsolatos „,minden értelmezési kérdés és jogeset morális alapon dől el, hanem azt, hogy morális megfontolások is szükségképpen szerepet kapnak az értelmezésben.” TóтH Gábor Attila: A szólás méltósága. Századvég 2008/2. 130.

${ }^{4} \mathrm{Az}$ amerikai irodalomban oly sokak által vallott ökölszabály (,thumb on the scales in favor of free speech") eredetileg Kalventöl származik. Harry Kalven: The Concept of the Public Forum: Cox v. Louisiana. 1965 Supreme Court Review 1, 28.
} 
kihívásait tisztázzuk (minthogy ezt a munkát kifejezetten önálló értekezés tárgyának tartom), hanem az, hogy a sajtót érintő esetek sokszor magának a szólásszabadságnak a lényegéről is mindennél szemléletesebben szólnak.

b) A dolgozat célja a szólásszabadság magyar doktrínájának tisztázása. Ehhez először is határozottan állítanom kell, hogy a szólásszabadságnak létezik magyar doktrínája. Ma már - történelmi léptéket jelentve - csaknem harminc év alkotmánybírósági határozatai állnak a rendelkezésünkre, és egészen biztosak lehetünk abban, hogy a belőlük összeálló alkotmányos judikatúra egyedi és sajátos: nem az amerikai, nem a német, nem a strasbourgi, hanem a magyar alkotmányértelmező elme gyümölcse és lenyomata. A döntések lánca persze erősen támaszkodik a nyugati nemzetközi jogéletben és közös alkotmányos hagyományban kidolgozott elvekre és érvekre - a dolgozat módszere éppen erre a valóságra épül -, az idő előrehaladtával, újabb és újabb problémák megválaszolásával azonban a doktrína egyre inkább saját képünkre formálódik. Törvényszerủen van ez így, a szólásszabadság terén mindenképp. Ha igaz az, amit az imént állítottam, hogy a véleménynyilvánítás joga sajátosan érzékeny kapcsolatban van társadalmi folyamatainkkal, akkor természetes, hogy egyébként közös demokratikus értékeink is elöbb-utóbb a saját magunk közösségébe ágyazottan jelennek meg. Harminc év hazai alkotmánybírósági gyakorlatának elemzése mindenképp igazolja előzetes feltevéseinket: az értelmezések sora - szorosan a nyugati demokratikus hagyományba illeszkedve, de - végül sajátos hangsúlyokat hordozó doktrínává állnak össze.

Munkám közben mindvégig arra törekedtem, hogy megfelelő egyensúlyt tartsak egyfelöl az esetjogban foglalt hazai doktrína leírása és magyarázata, másfelől a doktrínát meggyőződésem szerint vezetni hivatott értékek képviselete között. A dolgozatnak fontos és megerősítö üzenete, hogy ez a törekvés nem bizonyult lehetetlen vállalkozásnak: a magyar gyakorlatból nagyon is kifejthető egy olyan szólásszabadságvízió, amely kellö összhangban van az általam vallott releváns alkotmányos értékekkel és célokkal. Másképpen fogalmazva: a hazai esetjog bőven elegendő muníciót szolgáltatott a szólásszabadság általam is helyesnek gondolt koncepciójának kibontásához. Olyan döntések mindig és minden judikatúrában lesznek, amelyek nem illeszkednek feszültségek nélkül saját narratívánkba, de ha összességében kellően meggyőzően tudjuk alátámasztani a magunk megértését, sőt esetleg az támasztható alá a legmeggyőzőbben, akkor munkánk hiteles lesz. A hitelesség érdekében ráadásul 
egyáltalán nem kell kikerülnünk a nehezebben felfüzhető eseteket. Épp ellenkezőleg: ha az interpretáció(nk) fősodrából kilógó, néha azonban kifejezetten markáns döntésekre találunk értelmes feloldást a gondolatmenetünk számára, akkor azzal érvelésünk központi szálát is erősítjük. Egy joggyakorlatnak nem kell tökéletesen homogénnek lennie - álláspontom szerint ez teljesen életszerütlen céltételezés is volna -, az viszont kulcskérdés, hogy koherens logikában tudjuk-e magyarázni, és értelmes feloldást tudunk-e találni az egymással nem harmonizáló határozatok által felvetett kérdésekre.

Talán nem haszontalan az elején kiemelnem, ami alighanem magától értetődő is lehetne, mégis állandó félreértés tárgya a szólásszabadság témáinak tárgyalásakor: a dolgozat a véleményszabadság jogának doktrínáját taglalja. Azokban a szempontokban igyekszik elmélyülni, amelyek közléseink jogi kezelését, azaz állami kényszerrel történő befolyásolását hivatottak jellemezni. Bár ezek természetesen korántsem függetlenek megszólalásaink morális vagy kulturális megítélésétől, a jogi megközelítés mégis határozottan sajátos dimenziót jelent. Az államilag tiltható, korlátozható magatartások köre nem egyezik meg az erkölcsi ítélet alapján megvetendő cselekedetek körével: ez általában véve is igaz, de különösen igaz a véleménynyilvánítás jogának gyakorlásával összefüggésben. Az, hogy államilag kikényszeríthető jogi norma adott esetben nem állítható fel, nem jelenti azt, hogy ne lenne más természetü, nagyon is világos és követendő elvárás a társadalomban. A magam vállalkozása ugyanakkor most megáll a jog logikájának feltérképezésénél.

c) A dolgozat a szólásszabadság magyar doktrínájának alapjaira fókuszál. Megközelítésem azt a meggyőződést tükrözi, hogy a szólásszabadság világában felmerülő újabb és újabb kihívások konceptualizálásában és megválaszolásában - a problémák részleteire is kiterjedő megértést követően - annak van döntő szerepe, hogy a válasz után kutató fejében rend van-e a doktrína alaptéziseit illetően. Nem pusztán arról van szó, hogy a doktrína bármely új kérdésének megoldása nem nagyon gyökerezhet másban, mint a korábban kifejtett alaptételek továbbfejlesztésében. A szólásszabadság terén nagy jelentősége van annak is, hogy ezek az alapok - ha valóban a helyükön vannak - a válaszadás szemléletét is meghatározzák. Egy európai, sőt nemzetközi vitát kavart közelmúltbeli konkrét példával élve: arra a kérdésre, hogy a Google-nak a magánszféra és a személyes adatok védelme érdekében törölnie kell-e 
bizonyos találatokat a keresés eredményei közül, ${ }^{5}$ nem önmagában a technológiai újdonságok és részletek között fogjuk megtalálni a választ. Míg azok természetesen nélkülözhetetlenek a probléma megértéséhez, a megoldáshoz már nem ezek fognak elvezetni minket, hanem az, hogy mit gondolunk a nyilvános kommunikációs tér jelentőségéről, benne a keresőmotoroknak a diskurzust szolgáló szerepéről, illetve a véleményszabadság és a magánszféra kapcsolatáról. Minden azon múlik tehát végeredményképpen, tudjuk-e honnan indulunk, és tudjuk-e, hová szeretnénk eljutni. Tájolóink pedig csakis a doktrína alapvetései, illetve a mögöttük felsejlő alkotmányos értékeink és céljaink lehetnek.

El kell ismernem, hogy a dolgozat merítése határozott szelekció eredménye. Bizonyos tételeket körbejárok, míg más fontos tételeket most nem érintek. Szelektálásom némiképp szubjektív, de reményeim szerint korántsem önkényes. Azoknak az alaptéziseknek az elemzésére vállalkoztam, amelyek személyes tapasztalataim szerint úgy szövik át nagy hatással a szólásszabadság doktrínájának egészét, hogy e szerepükhöz képest méltatlanul kevés tisztázó munka foglalkozik velük a magyar irodalomban. A már önmagában is a kutatómunka részét képező szelekció elsődleges szempontja tehát adott kérdéseknek a hazai eszmecserében és joggyakorlatban betöltött szerepe és jelentősége. Hogyan tudnánk például eljutni a részletkérdések értelmes tárgyalásáig, ha első lépésként nem határoztuk meg, mit akarunk egyáltalán a véleménynyilvánítás jogának hatálya alá vonni. Emellett az a szempont is növelte egyes kérdések vizsgálatának fontosságát, hogy sok esetben épp a legtöbbet emlegetett tételek tünnek leginkább reflektálatlannak, kidolgozatlannak. Ilyennek éreztem például a tartalomsemlegesség érvét, ami egyfelől meghatározó jelentőségű és állandóan hivatkozott eleme a hazai gyakorlatnak és diskurzusnak, de mintha kevesen kívánnának számot adni arról, hogyan is illeszthető be valójában a magyar doktrínába.

Mindezek eredményeképpen jutottam arra, hogy a magyar tudományos vitához a magam részéről most ezeknek az alapoknak a tisztázásával szeretnék hozzájárulni. Ez a hozzájárulás így értelemszerủen még az alaptézisek körében sem íródott a teljesség igényével.

\footnotetext{
${ }^{5}$ Lásd az Európai Unió Bíróságának a 131/12. sz. Google Spain SL, Google Inc. kontra Agencia Española de Protección de Datos, Mario Costeja González ügyben 2014. május 13-án hozott döntését
} 


\section{A módszer}

Munkám egyik érdekes vállalkozása az alkalmazott módszerben rejlik. A dolgozat egyfelől kapcsolódik a kontinentális jogtudományi munkák többségéhez, és jogdogmatikai kutatást végez. A szólásszabadság hazai joggyakorlatában használt vagy éppen kevésbé használt, a gyakorlatnak azonban meghatározó kereteket nyújtó fogalmakat és tételeket igyekszik „lepárolni”, 6 annak érdekében, hogy hozzájáruljon átgondoltabb, koherensebb alkalmazásukhoz. Másfelől ugyanakkor a jogdogmatikai módszer alkalmazásakor a dolgozat szokatlan eszközhöz nyúl: a hazai gyakorlat tisztázásához az amerikai jogirodalom áttekintését teszi meg kiindulópontnak. Az elemzés módszere így alapvetően két meghatározó elemből épül fel: az egyes kérdéskörökhöz tartozó, számunkra releváns tengerentúli diskurzus ismertetéséből, valamint a magyar alkotmánybírósági gyakorlat feldolgozásából. Mindkét elem tekintetében fontos megjegyzések kívánkoznak a kifejtés elé.

\section{Az amerikai irodalom szerepe}

Ami az amerikai kitekintést illeti, fontos leszögezni, hogy a dolgozat nem alkalmaz összehasonlító módszert. Tárgya nem az amerikai gyakorlat ismertetése és összevetése európai, hazai értelmezésekkel. Tengerentúli eseteket csak elvétve említek, és azt is csak annak erejéig, ameddig az irodalmi érvelés megértése feltétlenül igényli. Az elemzés tehát az amerikai jogirodalmat használja ugyan, de a magyar doktrínát kívánja tisztázni. Rendhagyó vállalkozás, amelynek magyarázata részint személyes élményben gyökerezik. A magyar doktrína alapjait körülvevő homályosság tapasztalatával párhuzamosan erősödött bennem az az érzés, hogy a tisztázásra vágyó gondolkodást hallatlanul inspirálja és segíti az amerikai diskurzus áttekintése. Korántsem azért, mert az egyes kérdésekre adandó válaszaink azonosak lennének itthon és az Egyesült Államokban - közhelyszámba megy, hogy nem azonosak. Ennek ellenére állítom, hogy a szólásszabadságról folytatott tengerentúli vita vizsgálata rendkívül termékeny lehet az európai, kiváltképp a magyar elemző számára is.

\footnotetext{
${ }^{6}$ SZABÓ Miklós - JAKAB András: A jogdogmatikai kutatás. In: JAKAB András - MENYHÁRD Attila (szerk.): A jog tudománya. Tudománytörténeti és tudományelméleti irások, gyakorlati tanácsokkal. Budapest, HVG-ORAC, 2015. 52.
} 
Az amerikai teoretikusok a véleményszabadság körében másoknál régebb óta és intenzívebben foglalkoznak éppen azokkal a horizontális, a doktrína egészét meghatározó elemekkel, fogalmi kérdésekkel, amelyek elemzésemnek is tárgyát képezik. Páratlanul gazdag diskurzusba nyerünk bepillantást, ha az Atlanti-óceán túlpartja felé fordítjuk tekintetünket. A dolgozatnak fontos kutatási célja e tekintetben már önmagában az, hogy ebből a már-már túlburjánzó irodalomból kiszürje a számunkra releváns érveket. Arra egyelőre csak érdekes (bár később még hasznosítható) melléktermékként tekintek, hogy ezzel egyszersmind olyan feldolgozását érhetjük el a szólásszabadság magyar gyakorlatának, amely a tengerentúli fogalomkészlet számára is értelmezhető.

Az amerikai irodalom gazdagsága ellenére ugyanakkor számot kell vetnünk azzal az alapvető módszertani kérdéssel, hogy használható-e ez a gondolatébresztő tudományos anyag a magyar joggyakorlat elemzéséhez. Nem tekintendő-e fából vaskarikának a külföldi irodalom és a hazai gyakorlat ilyen házasítása? Fajsúlyos figyelmeztetésekkel kell szembe néznünk, amelyek alappal intenek minket - legalábbis - nagy óvatosságra. Meggyőződésem ugyanakkor, hogy ezeknek az intelmeknek a tudatos szem előtt tartása mellett módszertani próbálkozásomat siker koronázhatja.

Szabó Miklós és Jakab András arra hívják föl a figyelmünket, hogy az amerikai (és az angol) jogtudományi hagyományból jórészt hiányzik a kontinentális jogászi gondolkodás számára alapvető jelentőséggel bíró szigorú fogalmi rendszerépítés. A tengerentúlon jellemzőnek számító „,örténeti-sztorizgató jellegű vagy policy-elemző” hozzáállás eszerint csak nehezen tud hozzájárulni a magunk jogtudományi tisztázásához. ${ }^{7}$ Nem vitatva ezeknek az érveknek az általános érvényét, a magam témájával kapcsolatban inkább arra helyezném a hangsúlyt, amit a hivatkozott szerzőpáros is elismer: az angolszász elemzések mindezek ellenére tartalmaznak „érdekes és átveendő” gondolatmeneteket. ${ }^{8}$ A szólásszabadság joga mindenképpen olyan terület, ahol e gondolatmenetek használhatósága kerül előtérbe. Ebben a körben ugyanis a szigorú fogalmi elhatárolások és jogdogmatikai formulázások - a kontinentális közegben is - eleve korlátozottabb célt tüzhetnek maguk elé. A dolgozat fejezetei a dogmatikai tisztázáson túl éppen azt igyekeznek több ponton körüljárni, meddig használhatók tisztán jogi fogalmaink és tesztjeink, és mikor van már inkább

\footnotetext{
${ }^{7}$ SZABÓ - JAKAB (6. 1j.) 55-56.

${ }^{8}$ SZABÓ - JAKAB (6. lj.) 56.
} 
annak meghatározó szerepe, hogy „fel tudjuk-e emelni belölük a fejünket”. A szólásszabadság lényegi kérdései ugyanis természetüknél fogva nem ragadhatók meg teljes mértékben formális jogi kategóriáinkkal. Fogalomképzésünk tárgyai, a szólások valósága és értékelése oly mértékben függ szituatív és kontextuális elemektől, hogy a szigorú absztrakt-rendszerező leírás a jogászi megértés számára is elégtelen önmagában. A formulákon túli világ becsatornázásához pedig sok szempontból már éppen a kontinentális gondolkodáshoz képest szabadabban mozgó, a külső kontextusra könnyebben kitekintő angolszász érvelésmód nyújt hathatósabb segítséget. Félreértés ne essék, természetesnek tartom, hogy ezek az érvek addig lehetnek csak relevánsak a számunkra, ameddig saját alkotmányjogi terminológiánkba, dogmatikánkba beilleszthetők. De ha sikerül megtalálni azokat a pontokat, ahol ez sikerrel hajtható végre, akkor jogi döntéseinket hüebben megragadó fogalmi kerethez jutunk. ${ }^{9}$

Ezzel összefüggésben talán az is említésre méltó, hogy a sokszor szenvedélyes álláspontokat hozó, érdekek és érvek átélhetőségéről is szóló véleményszabadságvitáinkhoz az Egyesült Államokban folytatott diskurzus több ponton is szemléletesebb nyelvezetet nyújt, mint saját terminológiánk. Segítheti például a szólásszabadsággal kapcsolatos problémáink megértését, ha nemcsak elvont alkotmányos értékek és jogok ütközéséről szólunk, hanem közvetlenül is beszélünk a szólásokkal okozott ártalmakról, azok átélhetőségéről és értékeléséről. Ez a nyelvi elmozdulás azért is fontos lehet a szólásszabadság barátai számára, mert a velük szemben érvelők - sokak empátiájára apellálva - nemegyszer használnak ,átélhetőbb” nyelvi fordulatokat.

A másik nehézség, amelyre mindenképp reagálnom kell a dolgozat módszertanának leírásakor, ismeretelméleti. Pierre Legrand arra hívja föl a figyelmünket, hogy a common law és a civil law rendszerek közti különbségek nem hidalhatók át pusztán azon az alapon, hogy adott körben hasonló vagy akár azonos jogi fogalmakat használnak. A jogi formulák társadalmi-kulturális háttere, valamint a jogi gondolkodásban, érvelésben betöltött szerepük és értelmük ugyanis oly mértékben eltérő, hogy a fogalomkészlet látszólagos hasonlósága vagy azonossága nem

\footnotetext{
${ }^{9}$ Bár ez a dolgozat más aspektusból - ti. konkrét tartalmi szempontok alapján - merít az amerikai diskurzusból, érdemes megjegyezni, hogy Armin von Bogdandy (is) azon az állásponton van, hogy a kontinentális jogtudománynak előnyére válik, ha - az európai jogdogmatikai szemlélet és az amerikai egyetemek kutatás-felfogása közti lényeges különbségek figyelembevétele mellett is - tanul a tengerentúli hozzáállásból és eredményekből. Armin von BOGDANDY: A nemzeti jogtudomány az európai jogi térségben. Kiáltvány. In: JAKAB András - MENYHÁRD Attila (szerk.): A jog tudománya. Tudománytörténeti és tudományelméleti irások, gyakorlati tanácsokkal. Budapest, HVG-ORAC, 2015. 815-817.
} 
eredményezhet valóban konvergáló szabályokat. ${ }^{10}$ A Legrand érveire való reagálás abban segíthet minket, hogy világosabban lássuk ennek a dolgozatnak a módszertanát. A hangoztatott kételyek ugyanis elsődlegesen a pozitív jogot vizsgáló komparatív munkák eredményeit érinthetik - ahogy maga Legrand is az összehasonlító jogi megállapításokat veszi célba. Dolgozatomban ugyanakkor nemcsak hogy nem kívánok a konvergálás mellett érvelő összehasonlító eredményeket bemutatni, hanem egyáltalán nem célom komparatív kutatások elvégzése. Alapvető állításom mindössze annyi, hogy az amerikai irodalom számunkra releváns fogalomkészletének elemzése jelentős mértékben hozzásegít minket a magyar joggyakorlat tisztázásához. Ez a feltevés természetesen nem légböl kapott: míg más körülmények között eleve megkérdőjelezhető lenne az értelme, addig ebben az esetben szilárd alapjai látszanak. A magyar Alkotmánybíróság kezdettől fogva sokat merített a szólásszabadság amerikai felfogásából, ${ }^{11}$ és eközben a hazai gondolkodásba is beemelte annak sok meghatározó szempontját. ${ }^{12}$ A tengerentúli diskurzus áttekintésének hasznait nem rontja le, hogy az Alkotmánybíróság más - különösen német - mintát is használt joggyakorlatának kialakításakor, ${ }^{13}$ így egyes dogmatikai elemek tisztázása kiváltképp az intézményvédelem körében - nem történhet amerikai kitekintéssel. Legrand figyelmeztetésére is reagálva a dolgozat következetesen igyekszik képviselni azt a hozzáállást, hogy az amerikai szólamok meghallása az értő fül számára nem az egységesítés erőltetéséről, hanem a fogódzók differenciált megragadásáról szólnak: a hasonlóságok terén segítenek feltárni számunkra a közös hagyomány mélyebb gyökereit, ahol pedig különbségeket találunk, ott éppen azok megértését mélyítik el bennünk.

\footnotetext{
${ }^{10}$ Pierre LEGRAND: European legal systems are not converging. 45 International and Comparative Law Quarterly 52 1996. 56-65.

${ }^{11}$ Ezt maguktól a „merítőktől” is tudhatjuk. Sólyom László mondta el, hogy a véleményszabadság terén „[t]ermészetesen a fontosabb döntések elött megnéztem az ottani gyakorlatot”, és a közösség elleni izgatás példáján túl az „amerikai hatás tagadhatatlan a közszereplökkel kapcsolatos szólásszabadságdöntésünkben is." SólyOM László: A , nehéz eseteknél” a bíró erkölcsi felfogása jut szerephez - Sólyom Lászlóval, az Alkotmánybíróság elnökével Tóth Gábor Attila beszélget. Fundamentum 1997/1. 40.

${ }^{12}$ Éppen ezért a magyar irodalomban sem előzmények nélküli gondolat, hogy az amerikai gyakorlat megértése fontos szempont saját doktrínánk tisztázásához. Vö. pl. MoLNÁR Péter: Gondolatbátorság. Szólásszabadság és közbeszélgetés az Egyesült Államokban és Magyarországon. Budapest, Új Mandátum, 2002; UDVARY Sándor: Alkotmányos médiajog? Az elektronikus média jogának elemzése az amerikai és a magyar alkotmánybiráskodási gyakorlat tükrében. Budapest, Károli Gáspár Református Egyetem, 2008; illetve KolTAY András: A szólásszabadság alapvonalai. Budapest, Századvég, 2009. De az amerikai kitekintés megkerülhetetlennek látszik a kommunikációs jogokkal fontos pontokon összefüggő információs szabadságok tárgyalásakor is: MAJTÉNYI László: Az információs szabadságok. Budapest, Complex, 2006.

${ }_{13}$ SAJÓ András: A liberális jog sorsa Magyarországon: a szólásszabadság kalandjai 1989 után. Jogtudományi Közlöny 2006/10. 371.
} 
Catherine Duprének a jelen módszertani magyarázathoz további szempontokat nyújtó mủvére utalva úgy is mondhatnám, hogy munkám a szólásszabadság amerikai doktrínája részleges magyarországi importjának jár utána. ${ }^{14}$ Egyfelől kétségtelen, hogy a tengerentúli hagyomány egyes elemeinek átvétele az importálás markáns példájának tünik: a kommunizmus irányított és cenzúrázott társadalmi diskurzusából kitörve a jogállami alkotmány értelmezői a véleményszabadság majd' százéves amerikai modellje felé (is) fordultak. ${ }^{15}$ Másfelől ugyanakkor a szólásszabadság fejlődő magyar doktrínája - kivételesen erős társadalmi kontextualitására tekintettel nem meglepő módon - később ékes bizonyítéka lett annak a tézisnek, hogy az így végrehajtott jogimport aligha jelenthet imitálást, és a joggyakorlatban előbb vagy utóbb törvényszerüen megjelennek az eredeti merítés korlátozott hatásának jelei. ${ }^{16} \mathrm{~A}$ fentiek után azonban nincs okunk arra, hogy megijedjünk ettől a feszültségtől, hiszen a dolgozat vállaltan ennek a kettőségnek a jegyében végzi el a kitüzött munkát: egyrészt kiemeli a tengerentúli import meghatározó elemeit, másrészt eredeti jelentésük tükrében, de már speciális magyar értelmükre fókuszálva tisztázza őket.

Mindehhez pedig magától értődően teszem már csak hozzá, hogy a magyar gyakorlat elemzésekor az egyes fejezetek természetesen a releváns magyar irodalmi források következtetéseire is kitérnek, a hazai tudományos viták medrébe helyezve jelen kutatás eredményeit.

\section{A hazai joggyakorlat}

A dolgozat módszerének másik eleme az Alkotmánybíróság döntéseinek elemzése. Ezzel összefüggésben először is az érdemel magyarázatot, miért szükítem le a magyar joggyakorlat vizsgálatát az elmúlt harminc év alkotmánybírósági termésére, amikor a bírósági, sőt hatósági (például médiahatósági) ${ }^{17}$ esetjog is fontos tanulságokkal szolgálhatna. Meggyőződésem, hogy ez az önkorlátozás nemcsak terjedelmi keretek betartására hivatkozva védhető, hanem módszertanilag is igazolható. Az elemzésben

\footnotetext{
${ }^{14}$ Catherine DUPRÉ: Importing the Law in Post-Communist Transitions. The Hungarian Constitutional Court and the Right to Human Dignity. Oxford-Portland Oregon, Hart Publishing, 2003

${ }^{15}$ DuPRÉ (14. 1j.) 55-60. Bár Dupré az emberi méltósághoz való jog magyar dogmatikájának német mintára való kiépítését elemzi, fogalmi kerete számunkra is hasznosítható.

${ }^{16}$ DUPRÉ (14. lj.) 60., 106.

17 Ennek fontosságára lásd: MAJTÉNYI László: Az ORTT szabadságjog-védelmi szerepéröl. Fundamentum 2010/2.
} 
érintett dogmatikai kérdések ugyanis mindenekelőtt az Alkotmánybíróság előtt dőltek el eddig is, és a bírói döntésekben foglalt jogértelmezések alkotmányossági felülvizsgálatát lehetővé tevő alkotmányjogi panasz bevezetésével ez a tendencia még világosabbá fog válni. ${ }^{18}$ Való igaz, hogy a bírósági és hatósági döntések szerves részei, sőt alakítói a hazai doktrína fejlődésének, a most tisztázandó alaptézisek és alapszemlélet tekintetében ugyanakkor az alkotmánybírósági értelmezések bírnak döntő jelentőséggel. Az alkotmány és benne az alapjogok hiteles, mindenkit kötő értelmezése ugyanis az alkotmánybíróságokra van bízva. ${ }^{19}$ A szólás szabadságának értelmezése ráadásul olyan terület, amelyre rátekintve az elemzők az alapjogvédelem általános tendenciáira is szívesen következtetnek. ${ }^{20}$

Másfelől meg éppen az igényelhet még előzetes tisztázást, hogy a dolgozat miért nem szűkíti tovább a vizsgálat tárgyát, kizárólag az Alaptörvény hatálybalépését követő alkotmánybírósági gyakorlatot tekintve relevánsnak. ${ }^{21}$ Ennek az az oka, hogy amint arra több helyen kifejezetten utalok is az egyes problémaköröknél - a számunkra most fontos dogmatikai kérdések esetében maga az Alkotmánybíróság is deklarálta már: nincs törés az Alaptörvény elötti és utáni értelmezések között. Az elemzés ismerteti is azokat a döntéseket, amelyek a korábbi határozatokban foglaltak megerősítése, továbbfejlesztése mellett törtek lándzsát. Ha ez így van, akkor pedig már kifejezetten megfordul a hivatkozhatóság logikája: a szólásszabadság doktrínáját vizsgálva nemhogy helyük lehet az új alkotmány elötti huszonöt év döntéseinek, hanem azok nélkül nem is érthetök meg teljesen a mai jogértelmezések. Az esetjogot elemezve ez jól látható: az Alkotmánybíróság (és hozzátehetjük: a rendes bíróságok és a hatóságok) gyakorlatát át- és átszövik a korábbi alkotmánybírósági érvekre történő utalások.

Külön szeretném még magyarázatát adni annak, hogy a kifejtés igen egyenetlenül tér ki a kérdésekhez tartozó strasbourgi joggyakorlatra. Egyes fejezetek részletekbe

\footnotetext{
18 Az elmúlt évtizedekben nem volt ritka, hogy az Alkotmánybíróság és a rendes bíróságok jogértelmezése és mércéi között fontos kérdésekben is komoly feszültségek voltak azonosíthatók. A bírói döntések közvetlen vizsgálatának lehetöségét megteremtő alkotmányjogi panasz révén ezek a feszültségek elöbb-utóbb feloldódhatnak. Vö. PACZOLAY Péter: Az Alkotmánybiróság új hatásköreiröl egy év elteltével. Alkotmánybírósági Szemle 2013/1.; illetve PACZOLAY Péter: Az Alkotmánybíróság alkotmányvédő szerepéröl. Alkotmánybírósági Szemle 2014/1.

${ }^{19}$ PACZOLAY Péter: Alkotmánybiráskodás. Alkotmányértelmezés. Jogfilozófiák sorozat, Budapest, 1995. 25-31.

${ }^{20}$ Lásd pl.: KIs János: Alkotmányos demokrácia. Három tanulmány. Budapest, INDOK, 2000. 227-230.

${ }^{21}$ Az Alaptörvény negyedik módosításával a „Záró és vegyes rendelkezések” közé iktatott szöveg szerint: „Az Alaptörvény hatálybalépése elött meghozott alkotmánybírósági határozatok hatályukat vesztik." (Alaptörvény 5. pontja)
} 
menően ismertetik az Emberi Jogok Európai Bíróságának vonatkozó eseteit, míg más fejezetek nélkülözik ezt. A dolgozatnak ez a karakterisztikája elöbb már említett célkitüzéséből fakad: a magyar doktrína tisztázására vállalkoztam, összehasonlító módszer alkalmazása e tekintetben sem állt szándékomban. Az emberi jogi bíróság szerepe ugyanakkor sajátos: fontos pontokon a hazai értelmezések megértése, de legalábbis magyarázata sem tud teljes lenni judikatúrájának figyelembevétele nélkül ahogy azt az alkotmánybírósági indokolásokban található sürü hivatkozások elörevetítik. $^{22}$ Ezeken a pontokon ezért érdemben kitérek a strasbourgi döntésekre, viszont ahol sem magyarázó, sem orientáló erővel nem bírnak, ott mellőzöm vizsgálatukat.

Mindezek alapján a dolgozat módszere összességében kétféle gyümölccsel kecsegtet: az elemzés végigkövetésével egyrészt a véleményszabadság leggazdagabb szakirodalmának számunkra releváns főbb témáiról kapunk rendszerező áttekintést, másrészt közelebb kerülünk a szólásszabadság magyar doktrínáját meghatározó alaptételek tisztázásához.

És ha mindezek mellett a véleménynyilvánítás jogához közelítő szemléletünk is formálódik, akkor a dolgozat szerzője alighanem elérte fő célját.

\footnotetext{
${ }^{22}$ Az EJEB kezdetektől jelentős hatásáról a magyar gyakorlatra lásd: SÓLYOM László: Kölcsönhatás az Emberi Jogok Európai Bíróságának esetjoga és a szólásszabadság védelme között Magyarországon. Állam- és Jogtudomány 1996-97/3-4.
} 


\section{A KÖZLÉSEK ALKOTMÁNYOS ALAPÉRTÉKE}

Amilyen sokszínű és gazdag az emberi gondolkodás, olyan színes az emberi kommunikáció is. Persze mindezekben magának az embernek csodálatra méltó gazdagsága és sokszínűsége nyilvánul meg: ahogy nincs két ugyanolyan arc és talán két mindenben egyező gondolat sincs, úgy nincs két teljes mértékben azonosan mondott vagy értett kifejezés sem. Egyfelől méltán csodálhatjuk ezt a színpompás valóságot, másfelől sokféleképpen el is kell igazodnunk valahogy a közlések rengetegében.

Az egyes megszólalásoknak például korántsem ugyanaz az értéke és a jelentősége. Az értékelés, amellyel egy közlést minősítünk, maga is többrétü. Bár sokan minden ítéletet és megoldást a jogrendtől várnak, e tekintetben különösen fontos hangsúlyozni, hogy más mércéknek is lenniük kell. A nyilvánosan tett kifejezéseinkért erkölcsileg is helyt kell állnunk, és kulturális értelemben is meg kell tudnunk védeni öket. Morális és kulturális mércéink szerint egyaránt döntenünk kell a szólások értékességéről vagy értéktelenségéről, helyességéről vagy helytelenségéről, támogathatóságáról vagy elvetendőségéről.

A közlések emellett a jog számára is eltérő értékkel, jelentőséggel bírnak. Alkotmányjogi értelemben véve a szólásszabadság az, amely a kommunikatív szituációk közül kiemeli a relevanciával bírókat. Ez a fejezet arról szól, hogy a szólások alkotmányos értékességéről való döntés nem ott kezdődik, amikor egy kifejezést megvédünk az állami beavatkozástól, hanem már azzal is a közlés jelentőségéről döntünk, ha a konkrét esetben relevánsnak tartjuk a véleményszabadság szempontjait. Ennek mélyebb megértéséhez az amerikai teoretikusok nyomában haladva el kell határolnunk egymástól a szólásszabadság hatályát az általa nyújtott védelemtől, és azonosítanunk kell azokat az értékeket, amelyek a közlések rengetegében kijelölik számunkra a véleménynyilvánítás jogának hatálya alá tartozókat. A dolgozat célkitüzéseihez hüen ugyanakkor ezt a munkát kifejezetten a hazai gyakorlatra fókuszálva végzem el, azt keresve, hogy a szólásszabadság magyar felfogása milyen válaszokat ad a felvetett kérdésekre. A szóba jövő értékek vizsgálata így e helyütt most nem a versengő igazolások és elméletek elvont ismertetésére és ütköztetésére, hanem saját doktrínánk megértésére szolgál. 


\section{Hatály és védelem elhatárolása a szólásszabadság doktrínájában}

A szólásszabadság hatályának kérdése - kimondva vagy kimondatlanul - minden szólásszabadság-vizsgálat első lépése. Annál is inkább érdemes rámutatni erre, mivel viszonylag ritkán „mondják ezt ki”, vagyis a bíróságok és más jogalkalmazók számos esetben anélkül bírálnak el véleménynyilvánítással kapcsolatos ügyeket, hogy megindokolnák, egyáltalán miért is tekintik relevánsnak a döntésnél a szólásszabadság szempontjait. Ezzel alapvetően semmi baj nincsen, hiszen az előkérdések tisztázó levezetésére általában nincs is szükség, azt leginkább csak mérföldkőnek számító döntések meghozatalánál nem lehet mellőzni. Egyéb esetekben a joggyakorlat jobbára adottnak veszi, hogy bizonyos kommunikációkat érintő kérdéseknél állami korlátozások esetében számításba jönnek a szólásszabadság tételei. A hatály háttérben maradó kérdése azonban ennél jóval izgalmasabb. ${ }^{1}$

A hatály meghatározása arra az alapvető kérdésre keresi a választ, hogy a szólásszabadság szabálya pontosan mit fed le, mire vonatkozik. ${ }^{2}$ Melyek azok az esetek, amelyeket a véleményszabadság felől nézve kell megítélnünk? A kérdés úgy is feltehető, hogy mit is értünk közelebbről „szólás” alatt? A kommunikáció mely típusaira, eseteire vonatkoztatjuk? Észre kell ugyanis vennünk, hogy azokat az alkotmányos érveket, amelyekkel a véleményszabadság kiteljesedését igyekszünk előmozdítani, nem tekintjük minden esetben relevánsnak, amikor emberi beszéd vagy kommunikáció képezi vizsgálatunk tárgyát. A szólásszabadság nem a „szólást mint olyat" védi. ${ }^{3}$ Nem gondoljuk például, hogy két magánszemély között kötött szerződés

\footnotetext{
${ }^{1}$ Egy alapjog hatályának és az általa nyújtott védelemnek a megkülönböztetése természetesen általános dogmatikai kérdés, mégsem tekinthetünk rá magától értődő fogalompárként - a szólásszabadság gyakorlatát nézve biztosan nem: látni fogjuk, hogy a joggyakorlat vissza-visszatérően összezavarodik e téren. A magyar alkotmánybírósági döntések egyébként - amikor szólnak róla, akkor - az alapjog hatályára újabban leggyakrabban az alapjog „védelmi köreként” utalnak. A dolgozatban tudatosan nem követem ezt a terminológiát, mert az itt tárgyalt fogalompár épp azt a veszélyt veti föl, hogy a kifejezés a dogmatikában el nem mélyülök számára megtévesztő lehet.

2 A problémát leginkább körbejáró angolszász irodalomban általában „lefedést” (coverage) és „védelmet” (protection) különítenek el egymástól, de a „lefedés” mellett jelen van a „hatály” (scope) kifejezés egyenértékủ használata is. Elöbbire lásd pl.: Frederick SCHAUER: Categories and the First Amendment: A Play in Three Acts. 34 Vanderbilt Law Review 265, valamint Eric BARENDT: Freedom of Speech. Oxford-New York, Oxford University Press, 2005. 74-78., utóbbira lásd pl. Robert C. PosT: Participatory Democracy as a Theory of Free Speech. 97 Virginia Law Review 477

${ }^{3}$ Robert C. PosT: Recuperating First Amendment Doctrine. 47 Stanford Law Review 1249 1994-1995. 1250.
} 
kifejezéseit önmagukban a véleményszabadság mércéi szerint kell kezelnünk. Hasonlóképpen nem gondoljuk, hogy két nagyvállalat vezetőjének beszélgetése arról, hogy a jövőben mindketten ugyanazon az áron értékesítsék termékeiket, a szólásszabadság kérdéseit veti föl. De azokra a megszólalásokra sem alkalmazzuk a véleményszabadság érveit, amikor orvos vagy ügyvéd az ügyfelét tájékoztatja. Vagy amikor otthon a vacsoraasztalnál vitatkozunk. A sort lehetne folytatni számos, a mindennapi életből vett helyzettel, amelyben ugyan beszélünk, de amelyet mégsem sorolunk a szólásszabadság kérdései közé. Ahogy az amerikai Legfelső Bíróság bírája, Oliver Wendell Holmes frappánsan megfogalmazta: a szólásszabadság célja nem az, hogy a nyelv mindenféle használatához mentelmi jogot adjon. ${ }^{4}$ Nemcsak negatív lista létezik ugyanakkor ebből a szempontból, hanem pozitív is, vagyis olyan, amely éppen anélkül helyez egy szituációt szólásszabadság-kontextusba, hogy egyébként bárki megszólalna. Bizonyos cselekedeteket „szólásnak” tekintünk, noha nem minősülnek beszédnek a szó köznapi értelmében. Jelvények viselését, zászlók lengetését, egyes ruhák felöltését és sok egyéb cselekvést olyannak tartunk, amelyek osztoznak a szólásszabadság jelentőségében. A szimbolikus szólások, illetve tágabban fogalmazva a kommunikatív cselekvések kategóriája önmagában is rendkívül érdekes elemzés tárgya lehetne, ${ }^{5}$ számunkra azonban most csak annak érzékeltetéséig van jelentősége, hogy a szólásszabadság hatálya - vagyis az a kör, amelyen belül relevánsnak tekintjük a véleményszabadság érveit - nem vág egybe a köznapi szólások körével: hol szükebben, hol tágabban vonjuk meg annál.

A szólásszabadság hatálya, a „szólás” fogalma tehát normatív természetű. Nem a hétköznapi értelemben vett beszéd, hanem a kommunikáció (megszólalások vagy egyéb cselekvések) bizonyos jellegzetességei teszik alkalmazandóvá a szólásszabadság garanciáit. Egyes verbális cselekvések nem, míg egyes nem verbális cselekvések pedig kifejezetten rendelkeznek ezekkel a jellegzetességekkel. ${ }^{6}$

Hogy melyek ezek a jellegzetességek, arról azóta, hogy Holmes bíró „feltalálta” a szólásszabadság modern elméletét, ${ }^{7}$ nagyon izgalmas és termékeny vita zajlik. A releváns attribútumok azonosítását az határozza meg, hogy miben látjuk a

\footnotetext{
${ }^{4}$ Frohwerk v. United States, 249 U.S. 204, 206 (1919)

${ }^{5}$ A kérdéskör összefoglalására lásd: Eric BARENDT: Freedom of Speech. Oxford-New York, Oxford University Press, 2005. 78-88.

${ }^{6}$ Frederick SCHAUER: Categories and the First Amendment: A Play in Three Acts. 34 Vanderbilt Law Review 265 1981. 272-273.

${ }^{7}$ Robert C. POST: Reconciling Theory and Doctrine in First Amendment Jurisprudence. 88 California Law Review 2353 2000. 2356.
} 
szólásszabadság elméleti igazolását. A hatály mibenlétének és a védelem kérdésétől elkülöníthető önálló szerepének belátásához nincs szükség arra, hogy ezeket az igazolásokat a klasszikus csoportosításoknak megfelelően áttekintsük. ${ }^{8}$ Számunkra most első lépésként az bír jelentőséggel, hogy bármelyik igazolást - vagy igazolásokat - is fogadjuk el, a szólásszabadság hatálya a kommunikációnak csak azokra a formáira, megjelenéseire terjed ki, amelyek ebből a szempontból értékesek. ${ }^{9}$ Ezeknek az értékeknek a magyar gyakorlat szerinti azonosítására majd később térünk rá.

A szólásszabadság által nyújtott védelem kérdése csak azután merül föl, hogy a vizsgált esetet a szólásszabadság hatálya alá vontuk. Az értékelésnek ebben a második fázisában arra kell választ adnunk, hogy a szólásszabadság alkalmazandó garanciái a szóban forgó szólást valóban megvédik-e az állam fellépésével szemben. Hatály és védelem elkülönítése éppen arra biztosít lehetőséget a jogalkalmazóknak, hogy anélkül kezeljenek valamit alkotmányos értelemben vett szólásként, hogy ezzel automatikusan védettséget is biztosítanának számára. ${ }^{10} \mathrm{~A}$ hatály azt dönti el, hogy a szóban forgó megszólalásra - annak kommunikációs jellegzetességei, műfaja, típusa miatt - a szólásszabadság érveit és mércéit alkalmazni kell, a védelem pedig már arra a további kérdésre ad választ, hogy a konkrét esetben a garanciák valóban pajzsot tartanak-e az állami korlátozások elé.

Hatály és védelem elhatárolása tehát elmosódik, sőt értelmét veszti akkor, ha a szólásszabadságnak - abban a körben, ahol relevánsnak tartjuk a szempontjait abszolút védettséget kívánunk biztosítani. ${ }^{11}$ Ez két okból sem tünik járható útnak. Egyrészt ez esetben olyan pontossággal kellene megvonnunk a hatályt, vagyis olyan precizitással kellene definiálnunk az alkotmányos értelemben vett „szólást”, ami a véleményszabadságot érintő tengernyi és rendkívül változatos eset tapasztalatával a hátunk mögött esélytelennek látszik. Másrészt még nagyobb problémát jelentene egy abszolutista kísérlet számára, hogy a totális védelem biztosítása érdekében a releváns szólások körét (a hatályt) minden bizonnyal sokkal szükebben tudná csak megrajzolni

\footnotetext{
${ }^{8}$ Az igazolásokat összefoglalóan lásd: HALMAI Gábor - TóTH Gábor Attila: Emberi jogok. Budapest, Osiris, 2003. 431-437.; KOLTAY András: A szólásszabadság alapvonalai. Budapest, Századvég, 2009. 25-48.; illetve SAJÓ András: A szólásszabadság kézikönyve. Budapest, MTA Állam- és Jogtudományi Intézet, 2005. 11-25.

${ }^{9}$ Robert C. PosT: Participatory Democracy as a Theory of Free Speech. 97 Virginia Law Review 477 2011. 478 .

${ }^{10}$ BARENDT (5. lj.) 76.

11 Ilyennek tekinthető például Alexander Meiklejohn eredeti elmélete. Alexander MEIKLEJOHN: Free Speech and Its Relation to Self-Government. New York, Harper Bros., 1948
} 
annál, mint amilyen körben a szólásszabadság szempontjainak valamilyen mértékü szereppel kell bírniuk. ${ }^{12}$ Nemcsak őszintébbnek, hanem célravezetőbbnek is tűnik tehát azon az úton járni, amely hatály és védelem elkülönítésével egyfelöl szélesebben húzza meg a szólásszabadság hatálya alá tartozó ügyek körét, másfelöl e körön belül különböző mértékü védettséget biztosít (és adott esetben nem nyújt védelmet) a kommunikációnak. El kell ismerni - és a dolgozat bőségesen rámutat majd erre -, hogy ez a módszer mind a hatály, mind a védelem tekintetében viszonylag bizonytalan elvi fogalmakat eredményez, ${ }^{13}$ gyakorlati következményeit tekintve - ahogy a magyar példákon is látni fogjuk - mégis ezzel tudjuk biztosítani, hogy a konkrét esetekben a szólásszabadság megfelelő védelmet kapjon, illetve a véleményszabadság, valamint a vele szemben felhozható alkotmányos jogok és értékek közti mérlegelés finomhangolására is csak így nyílik lehetőség.

Ha a szólásszabadság nyújtotta védelemnél tágabb hatály önmagában nem biztosít mentességet az állam beavatkozása alól, akkor miben ragadható meg a jelentősége a véleményszabadság garantálása szempontjából? Abban, hogy a hatály alá tartozó valamennyi szólás esetében a jogalkalmazók kötelesek számot adni azoknak a jellemzően szigorú - teszteknek az alkalmazásáról, amelyek a szólásszabadságot érintő szabályozás mércéjéül szolgálnak. Úgy is mondhatjuk, hogy hatály és védelem elhatárolása annak a gyakorlati következményekkel járó megragadásáról szól, hogy mekkora különbség van az olyan cselekvések között, amelyeknek semmi közük a szólásszabadsághoz, és azok között, amelyek annyit biztosan indokolnak, hogy az őket érintő eljárást szigorú alkotmányossági kontrollnak vessük alá. ${ }^{14}$

A hatály tehát a szólásszabadság védelmét szolgálja, mivel annyit feltétlenül biztosít, hogy szélesen meghatározott hatály esetén a szólásszabadság szempontjait a kommunikáció szélesebb spektrumában kell relevánsnak tekinteni. Egyes szólásoknak vagy szólás-típusoknak a véleményszabadság hatálya alá vonása a védelmi mechanizmus beindításának első lépése. Nem garantál védelmet, de garantálja a lényegesen körültekintőbb eljárást.

\footnotetext{
${ }^{12}$ Példa erre Meiklejohn elmélete, amelyet ö maga is korrigált, kiterjesztett. Alexander MEIKLEJOHN: The First Amendment is an Absolute. Supreme Court Review 1961

${ }^{13}$ SCHAUER (6. lj.) 277.

${ }^{14}$ Frederick SCHAUER: Must Speech be Special? 78 Northwestern University Law Review 12841983. 1290.
} 
Jól nyomon követhető ez az amerikai joggyakorlat 20. századi fejlődésén: a Legfelső Bíróság korábban a szólások jóval több csoportját zárta ki az Első Alkotmánykiegészítés hatályából. A két legtipikusabb példa talán a kereskedelmi reklámok és a rágalmazás megítélése. Míg a század közepéig az ezek körébe eső kommunikációktól a bírák eleve megvonták a szólásszabadság-szempontú értékelés lehetőségét, addig a század második felének joggyakorlata kiterjesztette rájuk a szólásszabadság hatályát. Akár a kereskedelmi szólások, ${ }^{15}$ akár a rágalmazás ${ }^{16}$ megítélését nézzük, nem arról van szó, hogy a Legfelső Bíróság az új precedenseket követően minden esetben védett véleménynyilvánításoknak tartotta őket, hanem arról, hogy az Első Alkotmánykiegészítés szempontjai szerint ítélte (és ítéli) meg őket. ${ }^{17}$ Ennek alapja mindenekelőtt az az új felismerés, hogy a szólásszabadság alkotmányos értékével ezek is kapcsolatban állnak, így adott esetben védelemre is igényt tarthatnak a kormányzati beavatkozással szemben. Azt például, hogy a közhatalmat gyakorlókat érő rágalmazás a szólásszabadság hatálya alá tartozó kérdéseket vet föl, ma már konszenzus övezi. ${ }^{18}$ Egyebek mellett tanulságos még a „támadó beszéd” (fighting words) kategóriájába tartozó megnyilvánulások megítélésének változása. Bár a Legfelső Bíróság a mai napig nem bírálta kifejezetten felül a „támadó beszédet” a szólásszabadság hatálya alól kivonó döntését, ${ }^{19}$ az azóta eltelt hetven év során egyetlen esetben sem hagyott jóvá olyan elítélést, amely ezen a kivételen alapult. ${ }^{20}$ Úgy tünik tehát, mintha a támadó szavakra sem állna már teljes mértékben az eredeti precedens szigorú érvelése: „A beszédnek van néhány olyan, jól meghatározott és szükre szabott kategóriája, amelyek megelőzése vagy büntetése sohasem vetett föl alkotmányossági kérdéseket." 21

\footnotetext{
${ }^{15}$ Virginia State Pharmacy Board v. Virginia Citizens Consumer Council, 425 U.S. 748 (1976).

${ }^{16}$ New York Times Co. v. Sullivan, 376 U.S. 254 (1964).

${ }^{17}$ A Bíróság ezzel a tudományos diskurzusban már korábban is jelenlévő álláspontokat karolt föl, ld. pl. a kereskedelmi szólások tekintetében: Martin R. REDISH: The First Amendment in the Marketplace: Commercial speech and the Values of Free Expression. 39 George Washington Law Review 4291971. 433-444.

${ }^{18}$ Ez nem jelenti azt, hogy a közszereplök szélesebb körü bírálhatóságának alátámasztására felhozott egyes érveket ne kérdőjeleznék meg. A „dermesztő hatás” érvét sajátosan járja körül Frederick SCHAUER: On the relationship between press law and press content. In: Timothy COOK (szerk.): Freeing the presses: The First Amendment in action. Baton Rouge, Louisiana State University Press, 2005. 51-68.

${ }^{19}$ Chaplinsky v. New Hampshire, 315 U.S. 568 (1942).

${ }^{20}$ Erwin ChEMERINSKY: Constitutional Law - Principles and Policies. New York, Aspen Publisher, 2006. 1002 .

${ }^{21}$ Chaplinsky v. New Hampshire, 315 U.S. 568 (1942) 569.
} 
Az amerikai példák már elörevetítik, miért kell érzékenynek lennünk arra, ha a szólások egyes csoportjait a véleményszabadság hatályából ki akarják zárni: ha lemondunk a szólásszabadság tesztjeinek alkalmazásáról, akkor a „kontroll nélküli” minősítésnek könnyen áldozatul esnek alkotmányos értékkel bíró megnyilvánulások is. Ez az alapállásunk akkor is helyes, ha egyébként beláttuk, hogy a hatály meghatározására azért is szükség van, hogy egyes szólások ne tartozzanak bele, mivel ennek hiányában meg szem elöl téveszthetjük azokat az alkotmányos értékeket, amelyeket a szólásszabadság garantálásával szolgálni kívánunk.

A hazai joggyakorlat példáin is azt szeretném érzékeltetni, hogy a hatály nem tehető függővé a konkrét megszólalás eseti jellemzőitől, különösen tartalmi elemeitől, hanem az adott kommunikációnak a szólásszabadság szempontjából alkotmányos értékkel bíró müfaji jellegzetességeinek kell meghatározniuk.

\section{A hazai joggyakorlat példái}

A szólásszabadság alkotmányos jelentősége révén a magyar Alkotmánybíróság gyakorlata is rendkívül gazdag ezen a területen, ám az esetjogból kiemelhetők olyan kérdéskörök, amelyek az átlagosnál alkalmasabbnak mutatkoznak a számunkra releváns vonások szemléltetésére. Tekintettel arra, hogy az Alkotmánybíróság az Alaptörvény hatálybalépése után is fenntartotta a szólásszabadság értelmezésének alapjait jelentő korábbi tételeit, ${ }^{22}$ vizsgálatunk során csaknem harminc év gyakorlatát vehetjük mérvadónak.

\subsection{A valótlan tényállítások}

Láttuk, hogy a hamis tényállítások, ezzel együtt a rágalmazás megítélése az amerikai esetjog egyik olyan klasszikusa, amelyen élesen kimutatható egy korábban kirekesztett kérdéskörnek az Első Alkotmánykiegészítés hatálya alá vonása. Annak ellenére, hogy a magyar Alkotmánybíróság a szólásszabadság kérdéseinek elemzésébe már egy olyan korszakban kapcsolódott be, amely ilyen váltások szükségességétől

\footnotetext{
${ }^{22}$ 7/2014. (III. 7.) AB határozat, megerősítette pl. 13/2014. (IV. 18.) AB határozat.
} 
megkímélte a gyakorlatát, a hazai környezetben is tanulságosnak tünik a „hatály és védelem" fogalompárt elsőként ezen a példán szemléltetni. Látni fogjuk, hogy a szólásszabadság hatályának tudatosítása e téren is fontos hangsúlyokkal segítheti a jogalkalmazást.

Az elmúlt években a szólásszabadság egy speciális kontextusában, a választási kampány során tett kijelentések körében több alkalommal is fölmerült a valótlan tényállítások megítélésének kérdése. Idöközi választási kampányban benyújtott kifogások nyomán került sor arra, hogy a jogalkalmazók a képviselőjelöltek egymással szembeni megnyilvánulásait értékeljék. Alkalmas kiindulópontot szolgáltat számunkra két, valamennyi jogorvoslati fórumot - azaz a választási szerveket és a Kúriát követően alkotmányjogi panasz nyomán az Alkotmánybíróságot is - megjárt ügy. Témánk szempontjából elsődlegesen nem is az az érdekes, hogy az Alkotmánybíróság mindkét esetben a vizsgált bírói döntés megsemmisítése mellett döntött, hanem a bírósági végzések ${ }^{23}$ szövegében felsejlő logikát érdemes szemügyre venni.

A bírói döntések azt vizsgálták, hogy a kifogásolt kijelentésekkel a megszólaló jelölt, illetve jelölő szervezet megsértette-e a választási eljárás jóhiszemü és rendeltetésszerű joggyakorlásra vonatkozó alapelvét. Mindkét ügyben úgy találták, hogy igen. Az indokolások szerint a szóban forgó kifejezésekkel azért sérült a választási alapelvben foglalt követelmény, mert azok már túlléptek az értékítélet keretein, és valótlan tényállításnak minősültek. Bár a bírói döntések idéznek az Alkotmánybíróság vonatkozó gyakorlatából, az indokolásokat olvasva úgy tünik, mégsem annak szellemében jártak el. Itt most nem is arra gondolok, ami miatt az Alkotmánybíróság mindkét végzést megsemmisítette: a testület megállapította, hogy az elhangzott kifejezések a kontextus egészét figyelembe véve értékítéletnek minősülnek, így a szólásszabadság védelme alatt állnak. Számunkra érdekesebb a bírói döntéseket aszerint szemügyre venni, hogy miként kezelik a hamis tényállításokat. Az indokolások szövegét olvasva legalábbis nem tünik alaptalannak egy olyan következtetés, hogy ezekben az esetekben a valótlan tényállításokat nemcsak a szólásszabadság aktuális védelmi körén, hanem már a hatályán is kívülre rekesztették. Erre utal, hogy az indokolások megállnak annak deklarálásánál, hogy a szóban forgó kifejezések tényállítások, és mivel valótlanok, ezért jogsértőek, és megvalósították a választási alapelv sérelmét. A döntések logikája viszonylag automatikus, vagyis a

\footnotetext{
${ }^{23}$ Kvk.I.37.191/2015/3. és Kvk.II.37.345/2015/3. számú kúriai végzések.
} 
releváns alkotmánybírósági precedens felhívásán túl, az abban foglaltak ellenére nem találunk érdemi érvelést arra vonatkozóan, hogy a szólásszabadság szempontjait hamis tényállításoknál, választási kampányban, képviselőjelöltek egymás elleni megszólalásainál miként kell figyelembe venni. Márpedig ha a jogalkalmazó nem veszi figyelembe ezeket a szempontokat, azzal azt is állítja, hogy ezek nemcsak a védelmen, hanem a hatályon is kívül esnek. Elképzelhető, hogy ez a mulasztás csupán az indokolások elnagyoltságának tudható be, ami pedig a választási eljárási határidők rendkívüli szorításának számlájára írható, ám ettől még ezek az esetek így mindenképp alkalmat adnak arra, hogy tisztázzuk: a hamis tényállítások a magyar alkotmányjogi gyakorlatban (is) a szólásszabadság hatályán belül vannak, még ha sokszor nem is kaphatnak védelmet. Ennek egyértelmű szemléltetésére több alkotmánybírósági határozat is említhető lenne, de mindenekelőtt az alábbiakat érdemes kiemelni.

A 36/1994. (VI. 24.) AB határozat a közszereplők bírálhatóságának határait vizsgálva nagyon világos kijelentéseket tett a szólásszabadság hatályával kapcsolatban. Az Alkotmánybíróság e téren az Alaptörvény hatálybalépését követően is ezekböl a kijelentésekből, alkotmányjogi összefüggésekből indult ki, ${ }^{24}$ amelyek így továbbra is irányadók. A határozat rámutatott arra, hogy a véleménynyilvánítás szabadságának alkotmánybeli megfogalmazása nem tesz különbséget tényközlés és értékítélet között, ezért a szólásszabadság általában mindenféle közlés szabadságát magában foglalja, függetlenül erkölcsi minőségétől vagy akár valóságtartalmától is. Az Alkotmánybíróság világosan differenciál hatály és védelem között, amikor egyfelől leszögezi, hogy „a véleménynyilvánítás alkotmányos alapjoga nem korlátozódik csupán az értékítéletekre”, másfelől rögtön hozzáteszi, hogy „a véleménynyilvánítási szabadság határainak megvonásánál azonban indokolt különbséget tenni értékítélet és tényközlés között". 25

A 13/2014. (IV. 18.) AB határozat ezzel teljes összhangban képviselte azt az álláspontot, hogy ez a különbség nem abban áll, hogy a hamis tényállításoknál nem vesszük figyelembe a szólásszabadság melletti érveket, hanem abban, hogy speciális, a korlátozást az értékítéleteknél szélesebb körben lehetővé tevő mércéket alkalmazunk rájuk. A közhatalom és a közszereplök bírálata körében maga a határozat rajzolja föl azt a határvonalat, amelynek az egyik oldalán a valótlan tényállítások - bár hatályon

\footnotetext{
${ }^{24} 7 / 2014$. (III. 7.) AB határozat, Indokolás [24], [48]; 13/2014. (IV. 18.) AB határozat, Indokolás [23], [27], [31]

${ }^{25}$ 36/1994. (VI. 24.) AB határozat, Indokolás III.2., ABH 1994, 219, 230.
} 
belül vannak, de - védelem nélkül maradnak, a másik oldalán viszont még a szólásszabadság védelmét is élvezhetik. A hamis tényállítás e körben csak rosszhiszemüség mellett marad védelem nélkül. ${ }^{26}$

A 3328/2017. (XII. 8.) AB határozatot is figyelembe véve pedig már magabiztosan jelenthető ki, hogy az Alaptörvény hatálybalépését követöen is következetesen érvényesített gyakorlatról beszélhetünk ezen a téren: a határozat megerősíti a korábbi sztenderdeket, sőt részletekbe menően elemzi a belölük fakadó konkrét, részint eljárásjogi követelményeket.

Egy másik alkotmánybírósági döntés, amelyből nagyon szemléletesen kitünik a hamis tényállítások helye a szólásszabadság doktrínájában, a rémhírterjesztés büntethetőségéről szóló 18/2000. (VI. 6.) AB határozat. Az Alkotmánybíróság az előbb említett 1994-es határozatára jelentős mértékben támaszkodó indokolásában mindenekelőtt arról foglalt állást, hogy a büntető törvénykönyvben rémhírterjesztésként leírt magatartás, azaz a köznyugalom megzavarására alkalmas valótlan tényállítások nyilvános közlése egyáltalán a szólásszabadság hatálya alá tartozik-e. Korábbi tételeit követve a testület egyértelműen igenlő választ adott, és újfent leszögezte, hogy a véleményszabadság magát a megszólalás lehetőségét és tényét fedi le. Mivel pedig a valótlan tényközlés a szólásszabadság hatálya alá tartozik, az Alkotmánybíróság ez esetben is szigorú mércét alkalmazva döntött a vizsgált büntető rendelkezés alkotmányosságáról. A teszt ez esetben a köznyugalom megzavarásának minősített intenzitása (,,clear and present danger”) volt, ${ }^{27} \mathrm{ami}-\mathrm{a}$ rémhírterjesztés büntethetőségét csak közveszély helyszínére vagy háborús időkre szorítva - a tényállás alkotmányellenességére vezetett.

A valótlan tényállítások és a szólásszabadság kapcsolatának a fenti gyakorlatban kidolgozott elvi alapjait világosan összefoglalta a 34/2017. (XII. 11.) AB határozat. Miután felhívta az értékítéletek és a tényállítások megkülönböztetésének fontosságára rámutató korábbi gyakorlatot, a határozat azt is nyomatékosítja, hogy az Alkotmánybíróság „következetes volt annak hangsúlyozásában is, hogy bár az értékítéletekhez képest lényegesen eltérő mércék alapján ítélendők meg, a tényállítások is - valósak és valótlanok egyaránt - a szólásszabadság hatálya alatt állnak, és rájuk is

\footnotetext{
${ }^{26}$ 13/2014. (IV. 18.) AB határozat, Indokolás [31]

${ }^{27}$ Hogy más esetben, nevezetesen az uszítás megítélésekor is ezt a mércét alkalmazta-e az Alkotmánybíróság, arról lásd: TÖRÖK Bernát: A gyülöletbeszéd tilalmának médiajogi mércéi. Jogtudományi Közlöny 2013/2. 59-72.
} 
vonatkoznak a közügyek vitájának fokozott védelme melletti érvek.” Az érvelés igyekszik világossá tenni az alkotmányos helyzet differenciáltságát: egyfelöl - ahogy azt sokan szeretik dörgedelmesen idézni - „a hamis tényállítások - szemben az értékítéletekkel - önmagukban nem állnak alkotmányos védelem alatt", másfelől ahogy azt ugyanők már szeretik negligálni - ,az adott ügy összes körülményének mérlegelése arra vezethet, hogy mégsincs alkotmányos lehetőség a valótlan állítást tevő jogi felelősségre vonására". ${ }^{28}$

A hamis tényállítások alkotmánybírósági megítélésének magyar példája tehát nagyon jól szemlélteti a szólásszabadság hatálya és az általa nyújtott védelem megkülönböztetésének jelentőségét: nem arról van szó, hogy a valótlan tényközlések minden esetben alkotmányos védelem alá tartoznának (sőt), hanem arról, hogy mint a nyilvános diskurzus velejárói nem rekeszthetők ki a véleményszabadság köréből, ezért korlátozásukat - a közéleti véleménynyilvánítás körében mindenképp - szigorú mércék szerint kell megítélni. Ez a kötelezettség a választási ügyekben eljáró bíróságot akkor is kötelezi, ha egyébként helyesen ítéli meg a közlés tényállítás-jellegét.

\subsection{A kereskedelmi szólások}

A kereskedelmi kommunikáció, azon belül a gazdasági reklámok megítélése szintén olyan kérdéskör, amely nemcsak az „amerikai előtörténete” miatt érdekes, hanem azért is, mert a magyar gyakorlatban is tanulságokkal szolgál hatály és védelem kapcsolatával összefüggésben. A hazai esetjogot itt sem a nagy váltások jellemzik, sokkal inkább az alaptétel finomhangolása. Az Alkotmánybíróság alaptétele e tekintetben kezdettől fogva az, hogy a gazdasági reklámtevékenység ${ }^{29}$ a szólásszabadság hatálya alá tartozik. ${ }^{30}$ A kérdéssel elsőként foglalkozó 1270/B/1997. $A B$ határozat tanúsága szerint a testület alkotmányértelmezését ez esetben az Emberi Jogok Európai Bíróságának (EJEB) gyakorlata ihlette meg: az indokolás utal arra, hogy míg az EJEB a Barthold-ügyben még nyitva hagyta a reklámok Egyezmény általi védelmének kérdését, addig a Markt Intern ügy ítélete már világossá tette, hogy a

\footnotetext{
28 34/2017. (XII. 11.) AB határozat, Indokolás [33]-[34]

${ }^{29}$ A kereskedelmi kommunikáció köre egyébiránt szélesebb, mint a gazdasági reklámozás, de ennek a különbségnek számunkra most nincs jelentősége.

30 Összefoglalóan lásd: GELLÉN Klára: A kereskedelmi kommunikáció szabályozása. In: KOLTAY András

- NYAKAS Levente (szerk.): Magyar és európai médiajog. Budapest, Complex, 2012. 419-422.
} 
kereskedelmi jellegü információk nem zárhatók ki az Egyezmény 10. cikk 1. pontjának alkalmazási területéröl. ${ }^{31}$

Az EJEB gyakorlatára való utalás mellett az Alkotmánybíróság a hatály kérdését lényegre törö rövidséggel oldotta meg: korábbi döntéseire hivatkozva leszögezte, hogy a szólásszabadság magát a szabad kommunikációt fedi le, amelynek a kereskedelmi célú közlések is részét képezik. A testület a kereskedelmi kommunikáció sajátosságainak következményeit tehát nem a véleményszabadság hatályánál, hanem az által biztosított védelem kérdésénél vonta le: a kereskedelmi jellegű információk közzétételekor szélesebb körü állami beavatkozás lehet alkotmányosan indokolt, mint a véleményközlés más eseteiben, mivel a gazdasági reklámok nem állnak közvetlen kapcsolatban az egyéni önkifejezéssel és a demokratikus társadalmi részvétellel mint a kifejezés szabadságának alapértékeivel. A kereskedelmi szólások disztingvált megközelítésének szükségességére hívja fel ugyanakkor a figyelmet a 23/2010. (III. 4.) $A B$ határozat. Ez mindenben fenntartotta az elöbbi döntés tételeit, de figyelemre méltó kiegészítéseket füzött hozzájuk, amelyek a dolgozat második fejezetében fontos szerephez jutnak.

Mindemellett az Alkotmánybíróság abban is követte az EJEB gyakorlatát, hogy majd' minden esetben alkotmányosnak ítélte a gazdasági reklámozást érintő korlátozásokat. Így tett a személyhez füződő jogok sajátos védelme, ${ }^{32}$ a szexuális szolgáltatások, illetve a dohány- és alkoholtermékek kiterjedt korlátozása, ${ }^{33}$ továbbá a médiatartalmakban elhelyezett kereskedelmi kommunikáció szabályozása ${ }^{34}$ esetén.

Ami ebböl hatály és védelem összefüggésében azonnal levonható következtetés, hogy a kereskedelmi szólások hatály alá vonása jelentős mértékben eltérő védelmi szintek kialakítását eredményezte annak érdekében, hogy a joggyakorlat ne veszítse szem elöl a szólásszabadság alapértékeit. Akár az is fölvethető lenne, hogy mi értelme volt a védelmi szintet ilyen mértékben ,destabilizálni”, azaz mit nyerünk azzal, hogy a gazdasági reklámokat a szólásszabadság hatálya alá vonjuk. Azt gondolom, sokat. Nemcsak arról van ugyanis szó, hogy nyilvános közlésként már önmagukért is helyes a gazdasági reklámokat hatályon belül tartani, hanem arról is, hogy ezzel a szólásszabadság alapértékeit is hatékonyabban védjük. Azzal, hogy a kereskedelmi

\footnotetext{
31 1270/B/1997. AB határozat, Indokolás III.1., ABH 2000, 713, 715.

${ }^{32} 1270 / \mathrm{B} / 1997$. AB határozat

33 37/2000. (X. 31.) AB határozat és 23/2010. (III. 4.) AB határozat

${ }^{34}$ 165/2011. (XII. 20.) AB határozat
} 
kommunikációnál is a szólásszabadság érintettsége által indokolt körültekintéssel járunk el, annak esélyét nyerjük meg, hogy valóban nem marad védelem nélkül olyan közlés, amely már túlmutat a nyers gazdasági érdekeken, és szorosabb kapcsolatban áll a véleményszabadság alapértékeivel. Annak a disztingvált megközelítésnek van itt kulcsszerepe, amelyet az Alkotmánybíróság a fent ismertetett érvelésében hangsúlyoz: a kereskedelmi kommunikációnál, így a gazdasági reklámok esetében is mindig érzékenynek kell lennünk arra, hogy a szabályozás valóban csak a gazdasági érdekek kommunikálását korlátozza-e. Ha annál szélesebb körü korlátozással találjuk szemben magunkat, akkor a magasabb szintü védelmi mércék is müködésbe léphetnek.

A 23/2010. (III. 4.) AB határozat a vizsgált kérdések közül az egyiknél éppen e logika alapján lépett föl a reklámkorlátozó szabály ellen. A szóban forgó rendelkezés feljogosította az eljáró hatóságot, illetve a bíróságot, hogy megtiltsa a még közzé nem tett reklám közzétételét, ha megállapítja, hogy a reklám a gazdasági reklámtevékenységre vonatkozó elöírásba ütközne. Az Alkotmánybíróság abból indult ki, hogy az előzetes ellenőrzésnek ez a lehetősége - az általános fogalmazás következtében - a közlések rendkívül széles körét érintheti, különös tekintettel arra, hogy a sajtótermékben lévő reklámok közzétételének előzetes hatósági tiltása magának a sajtótermékeknek a megjelenését is akadályozhatja. Ez a „reklámszabály” tehát már nemcsak gazdasági érdekeket szolgáló, hanem kiemelt védelmet érdemlő kifejezéseket is érintett, aminek következtében az Alkotmánybíróság aránytalan korlátozásnak ítélte.

A közelmúlt egyik alkotmánybírósági ügye szintén fölvethette volna ezeket a kérdéseket. A 3208/2013. (XI. 18.) AB határozatban - más alaptörvényi hivatkozások elbírálása mellett - arról döntöttek az alkotmánybírák, hogy a közutak melletti reklámtáblák elhelyezésének rendjét a korábbiakhoz képest jelentős mértékben szigorító, számos új tilalmat bevezető szabályozás alkotmányellenesen korlátozza-e a szólásszabadságot. A határozat kifejezetten fenntartotta a korábbi gyakorlatban kidolgozott értelmezéseket, ${ }^{35}$ és a reklámozás lehetőségének szükítését a véleménynyilvánítás hatálya alatt vizsgálta. A fentiek tükrében mégis fölvethető, hogy a hatály jelentőségét mintha nem kellő súllyal vette volna figyelembe. A határozat a gazdasági reklámok alacsonyabb védettségének tesztjét alkalmazta, röviden hivatkozva arra, hogy az indítványozók nem hoztak fel olyan érvet, illetve az ügy egyéb körülményei sem utalnak arra, hogy a reklámelhelyezés vizsgált korlátozása olyan

${ }^{35}$ 3208/2013. (XI. 18.) AB határozat, Indokolás [104] 
hirdetéseket érintene, melyek jelentős közérdekű kérdésekhez kapcsolódnak, vagy hogy az érintett reklámtáblák esetében az üzleti érdekek összekapcsolódnának közügyek megvitatásával és a véleménypluralizmussal. Ezzel szemben azonban felhozhatók olyan érvek, amelyek szerint „az ügy egyéb körülményei” szigorúbb szólásszabadság-vizsgálatot érdemeltek volna. Már a mindennapi gyakorlat is óvatosságra int, hiszen a köztéri reklámplakátok rendszeresen válnak politikai üzenetek hordozóivá is, különösen választási időszakban. A releváns fogalommeghatározás pedig csak tovább növelhette volna a gyanakvást a korlátozással szemben, hiszen annak értelmében az új szabályozás kifejezetten vonatkozott azokra a hirdetésekre is, amelyek célja, hogy a közúton közlekedőket ideológiák, elvek, értékek, elképzelések támogatásáról vagy elutasításáról meggyőzze. ${ }^{36}$ Nehezen vitatható, hogy ez a fordulat már közvetlenül utal olyan közlésekre, amelyek szoros kapcsolatban állnak közügyek vitatásával, adott esetben jelentős közérdekü kérdésekkel. Nem véletlen, hogy amikor egy későbbi jogszabály-módosítás a definícióban már kifejezetten feltüntette a választási plakátokat, ${ }^{37}$ akkor voltak, akik a kormányzati lépést csupán olyan pontosításként értelmezték, amely érdemben nem vont be újabb kategóriát a korlátozás hatálya alá. ${ }^{38}$ Márpedig ha a korlátozás közéleti közléseket is érintett, akkor az a határozatban felhozott szempontokat lényegesen más megvilágításba helyezi.

Mindezek alapján ez az ügy annak lehetett volna újabb példája, hogy - túl a formális érvelésen - miért is lehet fontos a szólásszabadság hatálya alá vonnunk a reklámok szabályozását. Azért, mert a nyilvános üzenetként a közlési szabadság szempontjából önmagukban is számításba jövő kereskedelmi szólások korlátozása nem elhanyagolható számú esetben olyan üzenetek visszaszorításának is eszköze, amelyeket már kiemelt védelem illet meg.

\footnotetext{
${ }^{36}$ A reklámtáblák, reklámhordozók és egyéb reklám célú berendezések közutak melletti elhelyezésének részletes szabályairól szóló 224/2011. (X. 21.) Korm. rendelet 1. §-a

${ }^{37}$ 5/2014. (I. 17.) Korm. rendelet 1 . §-a

38 http://mno.hu/belfold/lukra-futottak-a-jogvedok-a-valasztasi-plakatokkal-1207244; letöltés ideje: 2017. május 28.
} 


\subsection{A közösségeket sértő beszéd}

A szólásszabadság hatályának harmadik példáját, a közösségeket sértő szólások rendkívül sokrétű és izgalmas témáját az eddigieknél is szükebben értelmezve vonom be jelen fejezet vizsgálata körébe, és kizárólag egy szempont felvillantására szorítkozom. Meggyőződésem ugyanakkor, hogy a szólásszabadság jövőbeli alkotmányos értelmezése terén különösen fontos kérdésről esik most szó.

Az Alaptörvény IX. cikke eredetileg tömören foglalkozott a szólásszabadsággal, az (1) bekezdésben elismerve mindenki jogát a véleménynyilvánítás szabadságához. Később az Alaptörvény negyedik módosítása a (4) és az (5) bekezdés beiktatásával jelentősen bővítette a szöveget, amely így ma már külön rendelkezik arról, hogy a véleménynyilvánítás szabadságának a gyakorlása nem irányulhat mások emberi méltóságának a megsértésére, illetve a magyar nemzet, a nemzeti, etnikai, faji vagy vallási közösségek méltóságának a megsértésére. Mindezek után a hazai joggyakorlat nagy jelentőségü kérdésévé vált, hogy a jogalkalmazók - élükön e tekintetben az Alkotmánybírósággal - mit kezdenek ezekkel az új alkotmánybeli szövegekkel. E kérdésre egyelöre még nincs egyértelmü válasz, de az első reakciók részben a szólásszabadság hatályának és védelmének most vizsgált témáján belül is elhelyezhetők.

Az Alaptörvény IX. cikk (4) bekezdésének értelmezése terén mérföldkőnek számít a közéleti szereplők bírálhatóságának alkotmányos kereteivel foglalkozó 7/2014. (III. 7.) AB határozat. Az Alkotmánybíróság itt úgy ítélte meg, hogy az új szövegrész nem írta fölül a szólásszabadság korábbi felfogását, és „nem rontotta le” a korábbi tételeket. A testület abból indult ki, hogy szólásszabadság-értelmezésének kezdettől fogva sarokköve volt, hogy mások emberi méltósága a véleményszabadság korlátja lehet. ${ }^{39}$ Eszerint az Alaptörvény IX. cikk (4) bekezdése szövegszerüen is egyértelművé tette azt, ami az emberi méltóság alkotmányos helyéből egyenesen következik, ti. hogy az még a kitüntetett szereppel bíró véleményszabadságnak is korlátja lehet. Az alapjogok korlátozásának követelményeiből következően ugyanakkor az alkotmányossági kérdés ez esetben is mindig az, hogy pontosan mely esetben és meddig kell a szólásszabadságnak engednie, vagyis az emberi méltóság védelmét szolgáló korlátozás mikor minősül szükségesnek és arányosnak. Az Alkotmánybíróság szerint nyilvánvaló

\footnotetext{
39 30/1992. (V. 26.) AB határozat, Indokolás IV.2., ABH 1992, 167, 174.
} 
ugyanis, hogy az adott szabályozás emberi méltósággal való bármilyen összefüggése önmagában nem igazolhatja a szólásszabadság korlátozását, ellenkező esetben a szólásszabadság tartalma kiüresedne, mivel az emberi méltósággal, illetve az abból fakadó jogokkal a jogszabályi rendelkezések rendkívül széles köre áll közelebbi vagy távolabbi kapcsolatban. ${ }^{40}$

„Hatály és védelem” tekintetében mindezt abban foglalhatjuk össze, hogy az Alkotmánybíróság ebben a döntésében a szólásszabadság-vizsgálódások kereteit érintetlenül hagyta, a véleményszabadság hatályát nem szükítette, hanem továbbra is az általa nyújtott védelem esetről esetre történő körültekintő mérlegelése mellett kötelezte el magát. Hogy az Alaptörvény alapján ennek a védelemnek a korábbiakhoz képest több ügyben vagy szélesebb körben kell-e meghajolnia az emberi méltóság előtt, az éppen ezeknek a tüzetes vizsgálatoknak az eredményeképpen dönthető csak el. A közéleti szereplők bírálhatósága körében mindenesetre az Alkotmánybíróság fenntartotta a szólásszabadság kitüntetett jelentősége melletti érveket.

Eltérő megközelítés látszik azonban megjelenni egy másik döntésben. A közösségeket sértő beszéd kérdése speciális körülmények között, a parlamenti szólások megítélése kapcsán került - az új szabályok óta először - az Alkotmánybíróság elé. A testületnek országgyülési képviselők alkotmányjogi panasza alapján arról kellett döntenie, milyen alkotmányossági szempontok szerint kell megítélni a parlamenti fegyelmi jognak a felszólalások szankcionálására lehetőséget adó rendelkezéseit. A 3206/2013. (XI. 18.) AB határozat több döntést is magában foglal a szólásszabadság hatályával kapcsolatban, amelyeket érdemes elkülönítenünk egymástól.

Az Alkotmánybíróság mindenekelött amellett foglalt állást, hogy a parlamenti szólásszabadságot a véleménynyilvánítás hatálya alá tartozóként kezeli, sőt a véleményszabadság lényeges alkotóelemének tekinti, mivel az Országgyűlés az ország sorsát érintő ügyekben a szabad véleménynyilvánítás érvényesülésének kiemelten fontos helyszíne. ${ }^{41}$ A testületnek ez az álláspontja az irodalom tükrében nem tekinthető magától értetődőnek, ${ }^{42}$ ugyanakkor meglepőnek sem lehet nevezni azok után, hogy mind a korábbi gyakorlata, ${ }^{43}$ mind az EJEB esetjoga ezt az értelmezést vetítette előre.

\footnotetext{
40 7/2014. (III. 7.) AB határozat, Indokolás [24] és [43]

41 3206/2013. (XI. 18.) AB határozat, Indokolás [21]

42 SZENTE Zoltán: Emberi jogok-e a parlamenti képviselöi jogok? A képviselöi szólásszabadság alkotmányjogi jellegéröl. Állam- és jogtudomány 2015/2.

43 33/1998. (VI. 25.) AB határozat, ABH 1998, 256.; 34/2004. (IX. 28.) AB határozat, ABH 2004, 490.
} 
Témánk szempontjából ismét arra juthatunk, hogy a parlamenti szólásszabadság megítélésekor olyan disztingvált megközelítésre van szükség, amely bár lehetőséget nyújt a kérdéskör sajátos kezelésére, de ezt nem azzal éri el, hogy a szólásszabadság hatálya alól teljesen kivonja ezeket a közléseket, eleve alkalmazhatatlanná téve a véleményszabadság mércéit. Ahogy azt az egyik - a határozattal más ponton vitatkozó - különvélemény kifejti: bár a képviselöi beszédjog közvetlenül nem a véleményszabadságból, hanem a szabad mandátumból ered, akkor, amikor a szabályok e beszéd gyakorlása elé tartalmi korlátokat állítanak, lehet hivatkozni a véleménynyilvánítás szabadságának sérelmére is. „Más kérdés, hogy a korlátozás alkotmányossága megítélésénél figyelemmel kell lenni a képviselői beszédjog sajátosságaira is. Ha azonban a parlamenti szólásokat teljes mértékben kivonnánk a véleménynyilvánításra vonatkozó alkotmányos tesztek alól, akkor az azzal a veszéllyel járna, hogy e körben a szólásszabadság lényeges tartalma sérül." ${ }^{\text {,4 }}$ A sajátos védelmi szempontok igénye megint csak nem egyenlő a hatály elismerésének tagadásával.

Azután, hogy a parlamenti felszólalások kategóriáját a véleményszabadság hatálya alatt tartotta, az Alkotmánybíróság két további ponton - az indítványok által támadott rendelkezésekhez igazodva - a kifejezések tartalma alapján is a szólásszabadság hatályának kérdését járja körül. A testület először is leszögezi, hogy a parlamenti képviselő által az Országgyülés ülésén alkalmazott fizikai erőszak, illetve a közvetlen fizikai erőszakkal való fenyegetés nem tartozik a véleményszabadsága körébe. Meggyőződésem szerint ez a kérdés rövidre zárható úgy, ahogy az Alkotmánybíróság tette: a fizikai erőszak alkalmazása vagy a fizikai erőszakkal való közvetlen fenyegetés aggálymentesen kirekeszthető a szólásszabadság hatályából, hiszen a józan észnek megfelelő konszenzus övezi, hogy ezek a cselekmények már nem tartoznak a közlések, kifejezések körébe, nem terjed ki rájuk a szólás normatív kategóriája.

A határozat azonban hasonlóan röviden ítéli meg a valamely személyt, csoportot különösen valamely nemzeti, etnikai, faji vagy vallási közösséget - kirívóan sértő kifejezések használatát is. Érvelése szerint tekintettel arra, hogy az Alaptörvény IX. cikk (4)-(5) bekezdése alapján a véleménynyilvánítás alaptörvényi védelme eleve nem terjed ki ezekre az esetekre, ezeknél a véleményszabadság sérelme fel sem merülhet. Meggyőződésem szerint ez a kérdés viszont már összetettebb. A döntés indokolása ezen a ponton ugyanis azon az értelmezésen alapul, hogy az Alaptörvény IX. cikk (4)

\footnotetext{
${ }^{44}$ Paczolay Péter különvéleménye, 3206/2013. (XI. 18.) AB határozat, Indokolás [111]-[113]
} 
és (5) bekezdése a szólásszabadság hatályát szükíti le, kirekesztve abból a mások emberi méltóságát vagy a közösségek méltóságát sértő beszédet. Eszerint az olyan megszólalások alkotmányos megítélése körében, amelyek valakire vagy valakikre sértő tartalmat hordoznak, nincs is helye a szólásszabadság-szempontok mérlegelésének - ahogy ez a mérlegelés hiányzik is az Alkotmánybíróság döntéséből. És noha a konkrét esetben „kirívóan sértő” kifejezésekről szólt a vizsgált rendelkezés, ha az alaptörvényi mondatoknak ilyen értelmet adunk, akkor valójában bármely sértés esetén hasonlóan járhatunk el, hiszen az alkotmányszöveg nem kvalifikálja a sértegetést. A sértő beszéd így a törvényi szabályozás szabad prédájává válik, amelynek alkotmányossági vizsgálata körében fel sem vetődhet, hogy a jogalkotó a szólásszabadságot arányosan korlátozó megoldást választott-e, vagy esetleg például büntetőjogi szankciókat helyezett kilátásba nem is annyira súlyos sértések esetére. Hatály és védelem elhatárolása épp erről szól: ha a szólásszabadság hatálya alól eleve kivonunk a nyilvános diskurzus részét képező egyes megszólalásokat, akkor valójában a disztingvált, azaz a helyes mérlegelés esélyét hordozó alkotmányossági megítélés lehetőségéről mondunk le.

Ehelyett ez esetben is azt az utat kellene követni, amely a szólások védelméről a véleményszabadság körében végzett körültekintő vizsgálat után hoz döntést. Ha már amint láttuk, indokoltan - a kereskedelmi kommunikáció körében is ezt az utat járja az Alkotmánybíróság, akkor még kevésbé tehetne mást egyértelmüen közéleti megszólalások esetében, függetlenül attól, hogy azok sértőek-e valakire vagy valakikre nézve. A 7/2014. (III. 7.) AB határozat logikájáról van itt szó: az emberi méltóság bármilyen érintettsége nem lehet aduász a szólásszabadsággal szemben, hanem - a méltóság alkotmányos helyét figyelembe véve, de - esetről esetre mérlegelve lehet csak megtalálni a helyes egyensúlyt. Ha egy szabályozás az emberi méltóság, illetve a „közösségek méltósága” védelmének célját követi is, attól még nagyon is számot kell adnia a szükséges és arányos korlátozás követelményéről. Ellenkező esetben a hatályából való kirekesztés igazolási deficitjével találjuk szemben magunkat.

A közösségeket sértő beszéd, a tágabb értelemben vett gyülöletbeszéd a szólásszabadság hatálya alá tartozik, valamennyi megnyilvánulásával együtt. A hatály alá vonás ugyanis nem múlik máson, minthogy a kommunikációnak az az esetköre, típusa, amelybe tartozik, kétségkívül kapcsolatban áll a szólásszabadság alkotmányos értékeivel. A társadalmi csoportokat érintő közéleti szólások szinte mindig 
kapcsolódnak a nyilvános politikai diskurzushoz, sőt kifejezetten a közvélemény formálásának igényével lépnek föl. Ehhez képest már más kérdés, hogy e megnyilvánulások közül némelyeknek, például a gyülöletre uszításnak - további körülményeket mérlegelve - nem jár alkotmányos védelem. Ez a fejezet mindeddig e különválasztás fontosságára igyekezett rámutatni.

\section{A szólásszabadság hatályának magyar koncepciója}

A magyar joggyakorlatból vett három fenti példával eddig a szólásszabadság hatályának és az általa nyújtott védelemnek az elhatárolását szemléltettük, jelezve annak központi jelentőségét a szólásszabadság kérdések jogi kezelésének igazolása terén. Bár ennek során nagyon közel jutottunk, sőt itt-ott már bele is kezdtünk magának a hatálynak a meghatározásába, e munka világosabb elvégzése még hátra van. Tisztáztuk, hogy a hatály alá vonás kérdése nem több, minthogy a szóban forgó kommunikatív aktus olyan jellemzökkel rendelkezik-e, amelyek kapcsolatban állnak a szólásszabadság alkotmányos értékeivel. Ezeknek az értékeknek és az általuk kijelölhető hatálynak a magyar joggyakorlatban való megjelenését azonban még nem jártuk körül, mindössze addig jutottunk, hogy a hatály láthatóan a nyilvános diskurzus minél szélesebb körét igyekszik felölelni. Miként ragadható meg pontosabban a szólásszabadság magyar felfogásának hatálya, azaz mit fed le a szabad véleménynyilvánításhoz való jog? Ennek megválaszolásakor nagymértékben támaszkodhatunk az eddig elmondottakra, hiszen sok szempontból a korábbi példáinkból levonható következtetések összegző, világos megfogalmazására van most szükség.

\subsection{A közlések alkotmányos alapértéke}

A szólásszabadság hatálya normatív természetű: a hétköznapi értelemben vett kommunikációs rengetegből a véleményszabadság alapvető alkotmányos értéke jelöli ki számunkra. Hogy ebből a szempontból mit tekintünk alkotmányos értéknek, az szoros összefüggésben áll a szólásszabadság elméleti igazolásaival. Ezeket a már több 
helyütt rendszerezett igazolásokat ${ }^{45}$ most csupán annyiban összegzem, hogy azok alapján közléseink alapvetően háromfajta értéket képviselhetnek: hozzájárulhatnak a közösen keresett igazság feltárásához, ${ }^{46}$ megnyilvánulásai lehetnek személyiségünk szabad kibontakoztatásának, ${ }^{47}$ illetve részvételt jelenthetnek a demokratikus társadalmi életben. $^{48}$

Az Alkotmánybíróság gyakorlata egyik érték fontosságát sem zárja ki a szólásszabadság hazai koncepciójából. Az Alaptörvény hatálybalépését követő alaphatározat, a 7/2014. (III. 7.) AB határozat a közéleti szereplők bírálhatóságával összefüggésben például kifejezetten utal mindhárom igazolásra, kifejtve, hogy az elemzett témakörben „az Alkotmánybíróság nem az egyes igazolások közötti különbségeket tekinti relevánsnak, hanem azt, hogy a közügyek lehető legszabadabb vitatásához füződő alapvető érdek egyértelmű találkozási pontja az elméleteknek. Az egyéni önkifejezés elsődlegességét hangoztató érvek értelemszerűen a közösségi ügyekben való megszólalás szabadságát is igénylik, az igazság közös keresésének, illetve a demokratikus közvélemény és akaratképzés fontosságának hangsúlyozása pedig legerősebben éppen a közügyek vitatásának minél teljesebb szabadságát követeli meg."49

A kereskedelmi kommunikáció alkotmányos helyét kereső határozatok - bár nem utalnak mindhárom megalapozásra, és az „igazság keresését” elhagyják - szintén nem keresnek kizárólagosságot a lehetséges igazolások és értékek között. Ehelyett a

\footnotetext{
${ }^{45}$ A 8. lj.-ben említett rendszerezö, ,tankönyvi” összefoglalásokon túl több cikk is érinti az igazolások kérdését a magyar szakirodalomban. Lásd pl. HANÁK András: Szent szólásszabadság. Fundamentum 2009/4.; illetve a gyülöletbeszédre fókuszálva TóтH Gábor Attila: Szólásszabadság és befogadó társadalom. Pro Futuro 2014/1.

${ }^{46}$ Ennek az igazolásnak a máig ható alapjait többszáz évvel ezelőtt kell keresnünk. John MiLToN: Milton, az angol forradalom tükre. Budapest, Gondolat, 1975; John Stuart MiLL: A szabadságról. Budapest, Századvég, 1994

${ }^{47} \mathrm{Az}$ individualista megközelítés melletti érvekre lásd mindenekelött Martin H. REDISH: The Value of Free Speech. University of Pennsylvania Law Review, 1982. 603., illetve Ronald DwORKIN: Freedom's Law. The moral reading of the American constitution. Oxford University Press, 1996. 199-202. A „hagyományos” individualista megközelítések mellett van, aki a befogadó autonómiájára fókuszálva érvel: Thomas SCANLON: A theory of freedom of expression. Philosophy and Public Affairs, Vol. 1. No. 2. (Winter 1972) 204.

${ }^{48}$ A demokratikus kormányzás felől közelítő, a témánk szempontjából releváns elméletekkel a dolgozat később részletesebben foglalkozik, Alexander Meiklejohn müveit tekintve modernkori kiindulópontnak. Ez azonban nem jelenti azt, hogy megfeledkezhetnénk e gondolatkör korai képviselöivel, akik a szólásszabadságot szintén a helyes kormányzással való kapcsolatában szemlélték. James MILL: Liberty of the press. In: Uö. Essays on government, jurisprudence, liberty of the press and law of nations. Augustus M. Kelley Publishers, 1986 (első megjelenés: 1811), illetve Jeremy BENTHAM: On the liberty of the press and public discussion. In: Works of Jeremy Bentham, vol. II. (ed. John Bowring). W. Tait, 1843 (első megjelenés: 1820)

${ }^{49}$ 7/2014. (III. 7.) AB határozat, Indokolás [9]-[13]
} 
szólásszabadság biztosításának céljait azonosítva mindvégig együtt említik, hogy az Alkotmánybíróság a kifejezés szabadságát elsősorban az egyéni önkifejezés elengedhetetlen eszközeként, illetve a polgároknak a demokratikus társadalomban való részvételeként részesítette többletvédelemben. ${ }^{50}$

A gyülöletbeszéd korlátozásának alkotmányos határáról döntő határozatok mindmind szintén a személyiség szabad kibontakoztatásának és a politikai közösség demokratikus müködésének zálogát látják a véleménynyilvánítás szabadságában. A joggyakorlatot összefoglaló 95/2008. (VII. 3.) AB határozat e tekintetben azzal érvel, hogy a politikai közösség tagjainak alapjogi egyenlöségéből következően mindenkit egyenlően megillet a közlés joga és az, hogy véleménye a demokratikus kommunikáció során megjelenjen. ${ }^{51}$

Szövegszerűen a hazai gyakorlat tehát mindhárom értéket megjeleníti a szólásszabadság keretei között: az egyéni önkiteljesedés, valamint a demokratikus közvélemény alakításának szolgálata kifejezetten hangsúlyos tétele az esetjognak, és olyan releváns döntést is találtunk, amely az igazság keresésének szempontját is felvillantja. Egyfelől tehát a szólásszabadság magyar koncepciója nem veti el egyik lehetséges igazoló értéket sem, hanem változó jelentőséggel, de mindegyiket felhasználja az érvelés megalapozása érdekében. Másfelől azonban ha a gyakorlat egészének lényegét szeretnénk megragadni, akkor ezeknek az értékeknek az igazoló erejét meg kell különböztetnünk egymástól, és egyiküket mint a szólásszabadság hatályát markánsan meghatározó érvet kell kiemelnünk.

Az ,igazság keresése” tünik a legkevésbé alkalmasnak arra, hogy a szólásszabadság hazai koncepcióját önmagában magyarázza. Nem arra gondolok, hogy az egyes igazolásokkal szemben már általános jelleggel is komoly kritikákat fogalmaztak meg, és ezek közül számos az „igazság keresésének” ideájához kötődik. ${ }^{52}$ Ezek a kritikák persze rendkívül gondolatébresztők és orientáló erejűek, jelen vizsgálódásunk célja mégis az, hogy a magyar alkotmányjogi tételek alapján keressünk koherens válaszokat a véleményszabadság egyes kérdéseire. Márpedig azt látjuk, hogy ez az érv az

\footnotetext{
${ }^{50}$ Összefoglalóan lásd a 23/2010. (III. 4.) AB határozatot.

${ }^{51}$ 95/2008. (VII. 3.) AB határozat, Indokolás III.2.1., ABH 2008, 782, 786.

${ }^{52}$ Lásd például: BARENDT (5. 1j.) 8-9., Frederick SCHAUER: Freedom of Speech: a Philosophical Enquiry. Cambridge, Cambridge University Press, 1982. 20-28., Wojciech SADURSKI: Freedom of speech and its limits. Boston, Kluwer Academic Publishers, 1999. 11., Lee C. BollingER: The tolerant society. New York-Oxford, Oxford University Press, 1986. 160-162., illetve kifejezetten az utilitarista megközelítésre ТóTH (45. lj.)
} 
alkotmánybírósági gyakorlatban önálló szempontként leginkább csak az említett 7/2014. (III. 7.) AB határozatban jelenik meg, és a véleményszabadság hatályához kötődő alapproblémák hazai megoldásai közül némelyik nem is magyarázható elsődlegesen ezen érték alapján. Korábbi példáink most is szemléletesek. Az igazság keresésének érve a tényállításokkal kapcsolatos számos speciális kérdésre nem tud igazán reagálni, többek közt nehezen világíthatná meg azt is, hogy tudottan hamis tényállítások összefüggésben állnak a szólásszabadság alkotmányos értékével. Láttuk ugyanakkor, hogy a hazai felfogás szerint ez az összefüggés nem vitásan fennáll. De gondolhatunk a kereskedelmi szólások hatály alá vonására is, hiszen a gazdasági reklámoknak jellemzöen nem céljuk a közösen keresett igazság kiteljesítése, annál sokkal materiálisabb és partikulárisabb célt szolgálnak. A szólásszabadság joga mégis fedi őket. Ez az érv tehát a magyar gyakorlatban önmagában nem bír kellő igazoló erővel a véleményszabadság hatályának meghatározásakor.

Lényegesen hangsúlyosabb érve e tekintetben a hazai szólásszabadság értelmezéseknek az egyéni kiteljesedés támogatása. Valahányszor az Alkotmánybíróság összefoglalóan szól a véleménynyilvánítás jogának alapértékeiről, mindig feltünik az az érv, hogy ez a jog nélkülözhetetlen a személyiség szabad kibontakoztatásához. Kétség nem férhet tehát hozzá, hogy az individualista nézőpont fontos és megkerülhetetlen része alkotmányjogi hagyományunknak. És mégis: ha a szólásszabadság hatályának legátfogóbb igazolását keressük, azt minden bizonnyal nem az egyéni kiteljesedés értékében találjuk meg. Az individualista álláspont elégtelenségét hangoztatók kritikája az Alkotmánybíróság esetjogára is vonatkoztatható. A kritikusok egyik legfőbb érve szerint az egyéni kiteljesedés (vagy másképpen egyéni autonómia) igazoló ereje mellett érvelők nem tudnak kellőképpen számot adni arról, hogy a közlések és a szólásszabadság miért és mennyiben nélkülözhetetlenebb a személyiség kibontakoztatásához, mint más cselekvések és jogok. ${ }^{53}$ Az könnyen belátható, hogy elengedhetetlen hozzá, de miért kevésbé fontos e tekintetben például a munka és az ahhoz való jog, vagy akár a szabadidős tevékenység szerepe. Még ha adódna is adekvát válasz erre a kérdésre, számunkra most annak van jelentősége, hogy az Alkotmánybíróság esetjogában nem fogjuk azt megtalálni, mert a döntések elsődlegesen nem ebben a logikában érvelnek. A szólásszabadság hazai

\footnotetext{
${ }^{53}$ Lásd: Joseph RAZ: Free expression and personal identification. Oxford Journal of Legal Studies (1991 Autumn); Schauer (14. 1j.); POST (9. lj.); Cass R. SunsteIn: Democracy and the Problem of Free Speech. New York, Free Press, 1995. 141-142.
} 
felfogásának központi eleme, hogy kiemelt jelentőséggel bír más jogokhoz képest, de ennek alátámasztására sehol sem találunk érvelést arról, hogy a megszólalások az egyének számára fontosabbak lennének az önkiteljesedéshez, mint más aktivitások.

A megfogalmazott kritikák másik fó érvét is igazolni láthatjuk a magyar gyakorlatban. Eszerint a személyiségünk kibontakozását számos olyan megnyilvánulásunk is szolgálja (sőt sok esetben erősebben kötődik hozzá), amely bár kommunikatív, mégsem soroljuk a véleményszabadság körébe. Otthonainkban tett kifejezéseink kapcsán például, bármilyen fontosak legyenek is számunkra és bármilyen következménnyel is járjanak, nem indul be a szólásszabadság érzékenységünk. A kézenfekvő választ, mely szerint a szólásszabadság a nyilvánosság előtti közléseket fedi le, megtaláljuk a hazai értelmezések között, ${ }^{54}$ de az nem vezethető le személyiségünk formálódásának fontosságából. Mindezzel pusztán annyit állítok, hogy a szólásszabadság hatálya nem vonható meg kellő pontossággal a személyiség kibontakozása felöl nézve. Az értelmezések nem adnak a kezünkbe olyan szempontot, amelyek a szólások és kommunikatív aktusok közötti válogatást - ti. hogy a szólásszabadság hatályába tartozónak minősítsük-e őket vagy sem - az egyéni kiteljesedés értékének szolgálata alapján teszik lehetővé.

Mindezek után amellett érvelek, hogy esetünkben a hatály a demokratikus társadalmi élettel összefüggésben ragadható meg a legpontosabban. Nem mindegy ugyanakkor az sem, miben látjuk ezt az összefüggést.

\subsection{A társadalmi kommunikációban való részvétel mint megkülönböztető jegy}

A szólásszabadságnak az az igazolása, amely a demokratikus közvélemény szabad formálódására fókuszál, nem tekinthető teljes mértékben egységes álláspontnak, legalább két fő irányzat megkülönböztethető egymástól. Ezek egyaránt szoros összefüggésben állnak a közvélemény formálásának gondolatával, fontos felfogás- és hangsúlybeli különbségeik révén mégis jelentős mértékben eltérő következtetéseket alapoznak meg.

\footnotetext{
${ }^{54}$ 19/2014. (V. 30.) AB határozat, Indokolás [42]
} 
Az egyik elmélet a szólásszabadság értékét abban látja, hogy elengedhetetlen a demokrácia lényegét jelentő közös, tájékozott döntéshozatalhoz. ${ }^{55}$ Legföbb rendeltetése, hogy a közügyek eldöntésében résztvevők, végső soron a választópolgárok minden szükséges információ, nézet és körülmény ismeretében hozhassák meg döntéseiket. A demokratikus közvélemény ez esetben főként a befogadókra, a véleményük kialakítása érdekében tájékozódókra koncentrál, és mindenekelőtt az ő érdekeiket tartja szeme előtt. A véleményszabadságnak így elsődlegesen a közös gondolkodási és döntéshozatali folyamat károsodása ellen kell védelmet nyújtania, adott esetben azzal, hogy határozott felhatalmazást ad e folyamat helyes, azaz a közvita minőségét biztosító kereteinek alakítására.

A másik elmélet a szólásszabadság értékét mindenekelőtt abban ragadja meg, hogy mindenki számára megnyitja a lehetőséget a demokratikus közösség életébe való bekapcsolódásra. A demokrácia és a demokratikus közvélemény fogalmának középpontjába itt a részvétel kerül: ${ }^{56}$ az a közösség és az a közvélemény tekinthető demokratikusnak, amely biztosítja tagjai számára gondolataik, nézeteik megosztásának lehetőségét. A szólásszabadság ebben a felfogásban jóval hangsúlyosabban fókuszál a beszélőre, jobban törődik közlési szándékával - teszi ezt a demokratikus közösség érdekében is,$-{ }^{57}$ ezért szükebb körben ad igazolást a kommunikációs folyamatba való beavatkozásra. Számára a demokratikus közvélemény elsődlegesen nem minőségi, tartalmi jegyekkel írható le, hanem a nyilvános diskurzusba kapcsolódás szabadságával, a nyilvánosság előtti kommunikáció minél robosztusabb folyásával. A nyilvános diskurzus fogalma ez esetben nem csupán a demokratikus döntéshozatal tárgyát közvetlenül érintő közléseket, vagyis a kifejezetten politikai, közéleti megnyilvánulásokat fedi le, hiszen a közösség életébe való bekapcsolódás, a társadalmi folyamatokban való részvétel lényegesen szélesebb körben értelmezhető.

Azt láthatjuk, hogy az Alkotmánybíróság csaknem harminc éves esetjoga összességében az utóbbi gondolat jegyében jelöli ki a szólásszabadság hatályát. Ez annyit jelent, hogy a joggyakorlat értelmében a szólások alkotmányos értékét - a hatály alá vonás erejéig - a nyilvános társadalmi kommunikációban való részvétel adja. Az Alkotmánybíróság alaphatározata, amelynek érvelését e tekintetben a testület

\footnotetext{
${ }^{55}$ MeIKLeJohn (11. 1j.); Robert H. Bork: Neutral Principles and Some First Amendment Problems. 1 Indiana Law Journal 1971. 20.

${ }^{56}$ Post (9. lj.)

${ }^{57}$ Vö. Robert C. Post: Meiklejohn's Mistake: Individual Autonomy and the Reform of Public Discourse. 64 University of Colorado Law Review 11091993
} 
mindmáig fenntartotta és döntések sorozatában megerősítette, a szólásszabadság igazolását elsődlegesen a társadalmi gondolatcsere felől fogalmazza meg. ${ }^{58}$ A szabad véleménynyilvánításhoz való jog azért különösen becses a plurális, demokratikus társadalom számára, mert mindenekelőtt ez teszi lehetővé az egyén megalapozott részvételét a társadalmi és politikai folyamatokban. Kitüntetett jelentősége abban áll, hogy az eszmék, nézetek szabad kifejtése, a demokratikus közvélemény kötetlen alakulása a fejlődni képes és eleven társadalom létezésének alapfeltétele. A véleménynyilvánítás, a demokratikus társadalmi gondolatcsere részvételi modellje ez, amelyből az a sokat idézett tétel következik, hogy a szólásszabadság a szabad kommunikációt - az egyéni magatartást és a társadalmi folyamatot - biztosítja, és nem annak tartalmára vonatkozik. ${ }^{59}$

Ez az érvelés egyrészt megadja számunkra azt a megkülönböztető jegyet, amely alapján a releváns kommunikatív aktusokat a szólásszabadság hatálya alá vonhatjuk: e tekintetben azok a közlések rendelkeznek alkotmányos értékkel, amelyek a nyilvános társadalmi kommunikációban vesznek részt. Másrészt az Alkotmánybíróság értelmezése világosan jelzi, hogy a hatály kijelölése ezzel le is zárul - az nem múlhat máson, minthogy a kommunikáció szóban forgó esetköre, típusa rendelkezik ezzel az attribútummal. A hatály alá vonás kérdése tehát nem tehető függővé a konkrét megszólalás eseti jellemzőitől, különösen tartalmi elemeitől. Minden szólás, amely része a társadalmi gondolatcserének, a szólásszabadság hatályába tartozik. És minden közlés, ami nem része, nem tartozik oda.

Ha így tekintünk az Alkotmánybíróság esetjogára, akkor kapjuk a legkoherensebb, legtisztább képet a véleményszabadság hatályáról. Világossá válik például, hogy az miért fedi le a hamis tényállításokat is. A nyilvános diskurzusban a megszólalók értelemszerüen nemcsak véleményeket, hanem tényeket is közölnek, és az már a védelem kérdésének körébe tartozó mérlegelésen múlik, hogy a tényállítás valótlansága indokolja-e a kommunikációs folyamatba való beavatkozást. Sokszor igen, de - mint láttuk - korántsem mindig.

Érthetővé válik az is, hogy az Alkotmánybíróság miért kezeli szólásszabadságkérdésként a gazdasági reklámok szabályozását. Nemcsak arról van szó, hogy a kereskedelmi szólások korlátozása nem elhanyagolható számú esetben politikai

\footnotetext{
58 30/1992. (V. 26.) AB határozat, ABH 1992, 167.

${ }^{59}$ Uo., Indokolás V.3., ABH 1992, 179.
} 
közlések visszaszorításának is eszköze, hanem arról, hogy a nyilvánosságnak szánt sokszínű üzenetekként önmagukban is számításba jönnek a szólásszabadság szempontjából. ${ }^{60}$ Kétségtelen, hogy diszkurzív jellegük adott esetben rendkívül csekély vagy hiányzik, de egyrészt ez bármikor „feléledhet”, másrészt nem vitathatóan információkkal, impulzusokkal látják el a nyilvánosságot, amelyet adott esetben akár tematizálhatnak is. Nem vitásan részei hát a társadalmi gondolatcserének.

A közösségeket sértő beszéd, a tágabb értelemben vett gyülöletbeszéd pedig eszerint magától értetődően a szólásszabadság hatálya alá tartozik, valamennyi megnyilvánulásával együtt. A társadalmi csoportokat érintő közéleti szólások szinte mindig kapcsolódnak a nyilvános diskurzushoz, sőt kifejezetten a közvélemény formálásának igényével lépnek föl. Korlátozásukat ezért minden esetben a szólásszabadság mércéivel kell megítélni.

A közbeszéd alakításának érvével azonban nemcsak az Alkotmánybíróság gyakorlatában fölmerült nagy elhatárolási kérdések érthetők meg, hanem a szólások és más kommunikatív aktusok rengetegében is nagyobb biztonsággal igazodhatunk el. Bár számos más megfontolás is erre vezet, önmagában ez az érv is képes magyarázni, hogy miért nem hívható föl a szólásszabadság családi perpatvarban, szerződés szövegéhez kötődően, vállalati vezetők kartellezésénél vagy orvos és páciense párbeszédében.

Teljesen egyértelmű ugyanakkor, hogy a nyilvános társadalmi eszmecsere részeként megfogalmazott szakmai és tudományos közlések eminens részei a szólásszabadság hatályának. Akkor tehát, amikor az Alkotmánybíróság ezzel ellentétes következtetésekre jutó indokolással utasította el a véleménynyilvánítás jogára alapozott panaszt, nemcsak elméleti tézisekkel, hanem saját következetes gyakorlatával is összeegyeztethetetlenül érvelt. A 14/2017. (VI. 30.) AB határozat egy munkajogi vita kapcsán arról foglalt állást, hogy egy szakmai internetes portálon közzétett írásai miatt elbocsátott munkavállaló ügye érinti-e a véleményszabadságot, vagyis ,,a jogvitában fennáll-e alapjogi érintettség”, ${ }^{1}$ Meggyőződésem szerint a kérdés megválaszolásakor az Alkotmánybíróság éppen azt a klasszikus hibát követte el,

\footnotetext{
60 Ezek alapján mindenképpen fenntartásokkal kell kezelnünk azt az álláspontot, mely szerint a gazdasági szólások éppen úgy tárgyai az állami beavatkozásnak, mint maga a gazdaság. Thomas $\mathrm{H}$. JACKSON - John Calvin JEFFRIES: Commercial Speech: Economic Due Process and the First Amendment. 65 Virginia Law Review 11979

${ }^{61}$ 14/2017. (VI. 30.) AB határozat, Indokolás [38]
} 
aminek kivédésére a dolgozat e fejezete íródott: összekeverte a szólásszabadság hatályát az általa nyújtott védelemmel, és az utóbbi körben releváns szempontokat az előzőhöz kötődően vizsgálta. A közéleti vitának az a tesztje, amely az Alkotmánybíróság következetes gyakorlatában - a következő fejezetben részletezett módon - a szólások védettségének mértékét jelöli ki, itt a közlések hatályba vonásának vált módszerévé. Nem meglepő ezek után, hogy a vizsgálat eredménye védhetetlen: a határozat szerint mivel a szóban forgó, a munkavállaló elbocsátásához vezető közlések „egy meghatározott szakmához tartozó kérdéseket, szakmabéli közönségnek címezve tárgyal[nak]”, céljuk a „tudásmegosztás”, kontextusuk pedig „ehhez a szakmaisághoz igazodik”, nem tartoznak a szólásszabadság hatálya alá. A „döntő részükben szakmai jellegü” írások „nem mutatnak olyan közéleti kötődést, amely ezt a tevékenységet a közügyek szabad vitatásának körébe sorolja”, így ezek a szólások nem állnak érdemi összefüggésben az Alaptörvény IX. cikk (1) bekezdésében garantált véleménynyilvánítás jogával. ${ }^{62} \mathrm{Nem}$ azt vitatom, hogy a konkrét ügyben szereplő írások a közügyek vitájához tartoztak-e vagy sem, hanem azt, hogy ennek a kérdésnek bármilyen megválaszolása az alkotmányos érintettségről való döntést jelenthetne. ${ }^{63}$

Az Alkotmánybíróságnak ez az érvelése, ha doktrínává válna, radikálisan és - mind elméletileg, mind a gyakorlattal - igazolhatatlan módon szűkítené le a szólásszabadság hatályát. Milyen doktrína lenne az, amely a kereskedelmi reklámozást következetesen szólásszabadság-kérdésnek tekinti, de nem teszi ezt meg a szakmai kérdésekről folytatott társadalmi viták és „tudásmegosztás” esetében? Amiben ugyanakkor őszintén reménykedhetünk, hogy ez a döntés oly mértékben szemben áll az egyébként általa is felhívott elvekkel és idézett következetes gyakorlattal, ami megakadályozza majd precedenssé válását. Más hasonló tényállás így inkább majd arra nyújt lehetőséget az alkotmánybíráknak, hogy kiköszörüljék ezt a csorbát, semmint hogy kövessék az itt kifejtett érvelést. Minket pedig ez az ügy már át is vezet következő fejezetünk fő kérdésére, hogy a véleményszabadság hatályának kijelölése után milyen szempontok szerint hozhatunk döntést egy szólás alkotmányos védettségéről.

\footnotetext{
${ }^{62}$ 14/2017. (VI. 30.) AB határozat, Indokolás [40]. A következtetés tarthatatlanságát két különvélemény is érzékeli, felhívva a figyelmet arra, hogy a határozattal elbírált ügy világosan a szólásszabadság hatálya alá tartozik: lásd Salamon László és Stumpf István alkotmánybírák különvéleményeit, Indokolás [45]-[48], illetve [49]-[53].

63 Teljesen más kérdés az alapjogok horizontális hatályának problémaköre, vagyis az, hogy milyen körben érvényesítendők alkotmányos jogaink akkor, amikor nem az államtól, hanem másik magánféltől kellene óvnunk őket. Az Alkotmánybíróság azonban nem ez alapján állapította meg az alapjogi érintettség hiányát, hanem önmagában arra tekintettel, hogy a közlés nem kötődik a közügyekhez.
} 
Összefoglalva azonban előbb jelen fejezetünk végkövetkeztetését: a nyilvános kommunikációban és a társadalom életében való részvétel más szempontoknál markánsabban és világosabban adja meg a szólásszabadság alkotmányos értékét. A véleménynyilvánítás jogának magyar felfogása az elmúlt csaknem harminc évben elsődlegesen ez alapján húzta meg e jog hatályát. Mindez ugyanakkor egyáltalán nem jelenti azt, hogy más érvek ne lennének jelen, sőt ne játszhatnának akár meghatározó szerepet egyes kérdéskörök vagy esetek megítélésekor. ${ }^{64}$ Kizárólagosságra törni az érvek között már csak azért is lehetetlen vállalkozás volna, mert az igazolások fontos pontokon összefüggnek és kiegészítik egymást. ${ }^{65}$ Csupán annyi állítható, hogy a demokratikus igazolás érvei segítenek nekünk a legtöbbet a véleményszabadság hatályának kijelölésekor és a doktrína átfogó magyarázatában. Leszögezhető ugyanakkor, hogy az egyéni autonómia, a személyiség kibontakoztatása továbbra is lényeges értéke a szólásszabadság magyar doktrínájának. Ez az érték egyrészt önmagában is szerephez juthat egyes kérdéskörök meghatározó elveként - mint látni fogjuk, ez olyan jelentős területek esetében is előfordulhat, mint a müvészi kifejezés szabadsága. Másrészt az egyéni önkifejezés értéke az átfogó koncepció, a demokratikus igazolás modelljére is nagyon jelentős érdemi hatással van: az a doktrína, amely érveléseiben a magyarhoz hasonló hangsúlyt fektet a megszólaló szempontjaira, egyértelmüen kilép az objektív aspektusra építő meiklejohni elképzelés keretei közül, és már csak a szubjektív elemeknek is nagy figyelmet szentelő részvételi modellbe illeszthető. Mindazonáltal találunk olyan kérdéskört, mindenekelőtt a médiaszabályozásban, ahol a demokratikus közvélemény érvének a tájékozott döntéshozatalra fókuszáló, minőségi elvárásokat is támasztó elgondolása jut fontos szerephez.

\footnotetext{
${ }^{64}$ Ahogy Post is „lexikális prioritásról” beszél az amerikai gyakorlatot elemezve. Post (9. lj.) 489. Az igazolások közeledéséről szól HALMAI Gábor: Túl kevés és túl sok szólásszabadság. Fundamentum 2005/3. 187.; KOLTAY András: A szólásszabadság igazolásai az angolszász jog és jogfilozófia fényében. Valóság 2007/9. 49.; vagy UDVARY Sándor: Alkotmányos médiajog? Az elektronikus média jogának elemzése az amerikai és a magyar alkotmánybiráskodási gyakorlat tükrében. Budapest, Károli Gáspár Református Egyetem, 2008. 53.; illetve az egyoldalúság veszélyére figyelmeztet MAJTÉNYI László POLYÁK Gábor: A szabadság hazai hagyományának megtagadása - új médiatörvények Magyarországon. Közjogi Szemle 2011/1., és POLYÁK Gábor: Új média, régi kérdések? A digitális átállás alkotmányjogi vonatkozásai. Fundamentum 2007/2. 38. Az igazolások egybeeséséröl szintén a sajtó példáján keresztül szól HANÁK András: Meddig nyújtózkodhat a magyar szólásszabadság? Amicus curiae az Alkotmánybíróság elött folyamatban lévö ügyben. Fundamentum 2001/2. 112.

${ }_{65}$ Judith LICHTENBERG: Foundations and limits of freedom of the press. In: Uö. (szerk.): Democracy and the mass media. Cambridge, Cambridge University Press, 1990. 334.
} 
És mindehhez nyugodtan hozzátehetjük: az sem árt, ha a törvényhozó bármikor, amikor a társadalmi eszmecsere kontextusában keres jogi eszközöket, azt is szem előtt tartja, hogy közösségi szinten az igazság belátására is sokszínű párbeszédben érhetünk csak el. 


\section{Következtetések}

1. A szólásszabadság hatálya, vagyis a „szólás” fogalma normatív természetü. Nem a hétköznapi értelemben vett beszéd, hanem a kommunikáció (megszólalások vagy egyéb cselekvések) bizonyos jellegzetességei teszik alkalmazandóvá a szólásszabadság garanciáit.

2. A releváns attribútumok azonosítását az határozza meg, hogy miben látjuk a szólásszabadság elméleti igazolását. A szólásszabadság hatálya a kommunikációnak csak azokra a formáira terjed ki, amelyek ebből a szempontból értékesek.

3. A szólásszabadság megfelelő védelmét az biztosítja, ha egyfelől szélesebben húzzuk meg a hatálya alá tartozó ügyek körét, másfelől e körön belül különböző mértékü védettséget biztosítunk a kommunikációnak. A szélesebb hatály a szólásszabadság védelmét szolgálja, mivel annyit feltétlenül biztosít, hogy a szólásszabadság szempontjait a kommunikáció szélesebb spektrumában kell relevánsnak tekinteni.

4. A szólásszabadság magyar joggyakorlata, így a jog hatályának kijelölése legátfogóbban a demokratikus részvétel szempontját középpontba állító igazolás alapján magyarázható.

5. A szólások alkotmányos alapértékét a nyilvános társadalmi kommunikációban való részvétel adja meg.

6. A hatály alá vonás kérdése nem tehető függővé a konkrét megszólalás eseti jellemzőitől, különösen tartalmi elemeitől: minden szólás, amely része a társadalmi gondolatcserének, a szólásszabadság hatályába tartozik; és minden közlés, ami nem része, nem tartozik oda.

7. A demokratikus részvétel szolgálata nem az egyetlen igazoló érv a szólásszabadság magyar koncepciójában: az egyéni autonómia, a személyiség szabad kibontakoztatása nagyon fontos kiegészítő (egyes kérdéseknél akár döntő) szereppel bír.

8. A joggyakorlatban a tájékozott döntéshozatal szempontja is szerephez jut, illetve az igazság keresésének érve is megjelenik. 


\section{A KÖZÜGYEK VITÁJÁNAK KÖRVONALAI}

A szólásszabadságról vallott nézeteink különfélék. Ez jól látható azokban a vitákban, amelyek a véleménynyilvánítás szabadságát érintő ügyekben újból és újból kibontakoznak: szinte nincs is olyan fajsúlyos, közérdeklődésre számot tartó szólásszabadság ügy, amely ne generálna szenvedélyes párbeszédet arról, hogy mi fér bele ebbe szabadságba és mi nem, hol kell már a jogi kényszer erejével fellépnie az államnak, hol pedig még nem. Különböző mögöttes igazolásokra és hagyományokra építve, eltérő érvelések mentén haladva sokszor radikálisan más következtetésre juthatunk. Ez önmagában véve egyáltalán nem baj - sőt nemegyszer a többhangú, társadalmunkat és jogfejlődésünket gazdagító párbeszédet ünnepelhetjük benne -, feltéve, hogy a vitázók néhány alapvető jelentőségü szabályt betartanak. Ilyen szabály, hogy ha a diskurzus - ahogy nagyon sokszor - arról szól, hogy állami szerveknek vane teendőjük, és ha igen, mi a teendőjük egy vitát kiváltó közlés nyomán, akkor az érvelőknek számolniuk kell a fennálló doktrínával, vagyis az alkotmányban és a jogszabályokban foglalt keretekkel, illetve a joggyakorlat által kidolgozott értelmezési irányokkal. A konkrét ügyben keresendő válasznak e doktrínát kell szem előtt tartania, ezt kell továbbfejlesztve követnie, ha pedig változtatni akar rajta valamit, ebből kell kiindulnia, erre kell reagálnia. Minden érvelés hátterében ott kell tehát lennie a fennálló doktrína azonosításának és megértésének.

A szólásszabadság diskurzust szemlélve azt gondolhatnánk, hogy a különféle elméleti megközelítéseknek és eltérő doktrínáknak van egy közös pontjuk, ahol az elméleti konszenzus aggálymentes gyakorlatot eredményez: a közéleti véleménynyilvánítás fontosságát senki nem vonja kétségbe, és annak helye a doktrínában egyértelmủ. Nem így van. Bár kétségtelen, hogy a politikai, közéleti beszéd jelentőségét sem irányzat, sem bírói fórum nem kérdőjelezi meg, az alaposabb vizsgálat után nyilvánvalóvá válik, hogy mind az elméleti hangsúlyok, mind a doktrínába illesztés terén komoly különbségek azonosíthatók. Ez a fejezet az említett hangsúlykülönbségek felvázolását követően arra a kérdésre keresi a választ, hogy a szólásszabadság magyar doktrínája - melyet mindenekelőtt az Alkotmánybíróság döntései, értelmezései alakítanak - hogyan ragadja meg a közügyek vitájának koncepcióját, és hogyan helyezi azt el a vizsgálandó kérdések között. 


\section{Hatály és a védelem körei}

\subsection{A demokrácia alapú elméletek megközelítése}

A közügyeket érintő véleménynyilvánítás kérdése mind a hatály kijelölésénél, mind a védelem megítélésénél jelentőséghez juthat. E tekintetben különösen az a 20. század közepe óta tartó diskurzus bír nagy jelentőséggel számunkra, amely a szólásszabadság demokratikus igazolása alapján igyekszik megragadni a releváns szempontokat. Egyrészt ez a diskurzus járja körül leginkább a véleménynyilvánítás és a közügyek alkotmányos viszonyát, másrészt a magyar joggyakorlat fősodra is - ahogy az előző fejezetben láttuk - ebbe a hagyományba illeszkedik, így az innen nyerhető érvkészlet a magyar doktrína megfogalmazásában is segítségünkre lesz.

Alexander Meiklejohn korszakos müvében a véleményszabadság kérdését egyértelműen a demokratikus önkormányzás eszméjéhez kötötte. ${ }^{1}$ Elméletének első kifejtésekor a szólásokra vonatkozó szabadságot - amire tudatosan nem ,jogként” (right), hanem „,hatalomként” (power) tekintett ${ }^{2}$ - a falugyülések példáját használva a közös döntéshozatalhoz nélkülözhetetlen vitára vonatkoztatta. Az önkormányzó polgárok nem az „akármikor, akárhol, akárhogyan való felszólalás” szabadságát vindikálják maguknak, hanem azt, hogy a közösség politikáját meghatározó döntésüket minden információ birtokában, valamennyi releváns álláspont megismerését követően, minél bölcsebben hozhassák meg. ${ }^{3}$ Meiklejohn gondolatmenetében tehát a véleményszabadság hatálya alá kizárólag a közös döntéshozatalhoz (to decide matters of public policy) szükséges szólások (közlések, álláspontok, információk) tartoznak bele.

A filozófus Meiklejohn elméletét Harry Kalven hamarosan azzal szembesítette, hogy nem nyújt magyarázatot arra a valóságban fennálló jogi helyzetre, amely a szólásszabadság számára relevánsnak tartja az irodalmi és müvészeti alkotásokat.

\footnotetext{
${ }^{1}$ Alexander MeIKLEJOHn: Free Speech and Its Relation to Self-Government. New York, Harper \& Brothers, 1948

${ }^{2}$ Alexander MeIKLEJohn: The First Amendment is an Absolute. 1961 Supreme Court Review 245. 254.

${ }^{3}$ MeIKLEJOHN (1. 1j.) 22-25. Meiklejohn megközelítésének egyik kiváló mai lenyomata: Owen M. FISS: Liberalism Divided: Freedom of Speech and the Many Uses of State Power. Boulder, Westview Press, 1996
} 
Kalven a döntéshozatalba túl szorosan kapaszkodó értelmezés gyengéjét éppen abban látta, hogy túlságosan élesen különböztet közügyekre vonatkozó és magánjellegü közlések között, mivel a politikai akaratképzés szempontjából a regények, színdarabok, költemények és festmények nem bírnak jelentőséggel - ezek mind lényegtelenek akkor, amikor a polgároknak dönteniük kell. ${ }^{4}$ Azt maga Kalven is vallotta, hogy a szólásszabadság központi jelentőségét a közügyek szabad vitája (debate on public issues) adja, de álláspontja szerint ez nem vezet oda, hogy minden más közlés annak hatályán kívül esne. Ha másért nem, hát azért mindenképp szélesebb kört kell lefednie a véleményszabadság hatályának, mert a jogalkalmazás során nem tudjuk kellő finomsággal meghúzni a határvonalakat. ${ }^{5}$

Meiklejohn a válaszában világossá tette, hogy saját értelmezésében a Kalven említette irodalmi és művészeti alkotások nem esnek kívül az általa korábban meghatározott hatályon. Személyes tanári meggyőződésének is hangot adva szögezte le, hogy az embereknek igenis szükségük van regényekre, színdarabokra, költeményekre és festményekre ahhoz, hogy jó döntéseket hozzanak. Épp e műveltség hiánya ronthatja le a sikeres demokratikus önkormányzás esélyeit. ${ }^{6}$ A polgárok a döntéshozatalhoz szükséges tudást, informáltságot és érzékenységet az emberi kommunikáció változatos formáiból nyerik, ezért a következőket mindenképp relevánsnak kell tekinteni a szólásszabadság számára: oktatás, filozófia és tudományok, irodalom és müvészet, valamint a közügyek nyilvános vitája (public discussions of public issues). ${ }^{7}$ Észre kell tehát vennünk, hogy a szólásszabadság hatálya még a demokratikus önkormányzáson, a közösségi döntéshozatalon kívülre nem tekintő Meiklejohn szerint is lényegesen többet ölel fel, mint a közügyek konkrét vitáját. A véleményszabadság ráadásul az ő számára ebben a szélesebb körben jelent abszolút kategóriát, amely alól nincs is helye kivételnek. ${ }^{8}$

A szólásszabadság (hatályának) politikai beszédre korlátozását Robert Bork képviselte a vitában. Ö éppen amiatt kritizálta Meiklejohnt és Kalvent, hogy az általuk is elismert alkotmányos kiindulópontot - ti. hogy a véleményszabadság a demokratikus politikai folyamatok biztosításában nyeri el értelmét - nem képviselik

\footnotetext{
${ }_{5}^{4}$ Harry Kalven: Metaphysics of the Law of Obscenity. 1960 Supreme Court Review 1. 15-16.

${ }^{5}$ Harry Kalven: The New York Times Case: A Note on "The Central Meaning of the First Amendment”. 1964 Supreme Court Review 191. 204-213.

${ }^{6}$ MeIKLEJOHN (2. lj.) 263.

${ }^{7}$ MEIKLEJOHN (2. 1j.) 256-257.

${ }^{8}$ MeIKLejohn (2. 1j.) 253., Alexander MeikLejohn: What Does the First Amendment Mean? 20 The University of Chicago Law Review 461 1952-1953. 466.
} 
következetesen, vagyis olyan közléseket is relevánsnak tartanak, amelyek már nem állnak világos (,semleges”) kapcsolatban a polgárok önkormányzásával. Bork számára a szólások alkotmányos értékét a politikai igazság megtalálásának és terjesztésének igazoló elve adja, ami azonban kizárólag a „kifejezetten és túlnyomórészt politikai” közlések (explicitly and predominantly political speech) speciális kezelését és védelmét indokolja. A Meiklejohn és Kalven által felhozott irodalmi és müvészeti alkotások bizonyos mértékben és közvetettséggel nyilvánvalóan formálják az emberek politikai véleményét is, de ezen az alapon szerinte minden, az emberek egyéniségére hatással lévő aktivitás (például üzletelés, szexualitás, házas együttélés) relevanciával bírna a szólásszabadság szempontjából. Az alkotmányos értéket kizárólag az alkotmányból levezető bírónak ezért a véleményszabadságot a közhatalom gyakorlását, a kormányzati tevékenységet érintő, közvetlenül politikai kommunikációra kell vonatkoztatnia. A tudományos, irodalmi, oktatási tevékenység kívül esik ezen a körön. ${ }^{9}$

A 20. század derekának e nagy hatású diskurzusa óta természetesen sok minden történt az emberi kommunikáció és a szólásszabadság doktrína fejlődéstörténetében. Általános gyakorlattá vált például, hogy nem csupán az irodalmi, művészeti alkotások tartoznak a szólásszabadság hatálya alá, hanem még a kereskedelmi célú kommunikáció is. Nyilvánvaló, hogy mindezek a változások reagálásra késztetik azokat, akik elméleti keretek közé igyekeznek terelni a doktrínát, a demokratikus alapok felöl közelítők számára pedig világos kihívásként jelentek meg.

A demokrácia-alapú igazolás új, a szólásszabadság-doktrínát modern keretek közé illesztő lehetőségét dolgozta ki Robert Post. ${ }^{10}$ Post számára a doktrína alapvető mögöttes értéke a demokratikus legitimáció (democratic legitimation), amely alatt azt érti, hogy az állam a polgárainak véleményére, igényeire, gondolataira nyitottan, fogékonyan, azokra reagálva müködik és szervezi a közösség életét (responsive state). ${ }^{11}$ Ennek a legitimációs alapnak, az állami müködés reszponzivitásának előfeltétele, hogy a polgárok gondolataik nyilvános közlésével szabadon vehessenek részt a társadalmi párbeszédben. Post kulcsfogalma ezért a társadalmi diskurzus

\footnotetext{
${ }^{9}$ Robert H. BORK: Neutral Principles and Some First Amendment Problems. 47 Indiana Law Journal 1. 21-35.

${ }^{10}$ Robert C. PosT: Democracy, Expertise and Academic Freedom: a First Amendment Jurisprudence for the Modern State. New Haven, Yale University Press, 2012

${ }^{11}$ Robert C. POST: The Constitutional Status of Commercial Speech. 48 UCLA Law Review 1 20002001.7.
} 
(public discourse), amely azokat a kommunikációs aktusokat és csatornákat öleli fel, amelyen belül a megszólalók kötöttségek nélkül oszthatják meg nézeteiket, közölnivalójukat annak érdekében, hogy az ily módon szabadon formálódó közvélemény demokratikus legitimációval ruházza föl a reá nyitott és fogékony államot. ${ }^{12}$ A pontosabb fogalmi tisztázást későbbre hagyva, az már Post elméleti keretezéséből nyilvánvaló, hogy a demokratikus igazolásoknak egy az állampolgárok társadalmi részvételére érzékeny, ${ }^{13}$ a közösségi tanácskozást szélesen értelmező modellje ez, amely korántsem szükíti le a szólásszabadság hatályát a politikai témákra. Ez persze azok után, hogy a kereskedelmi kommunikáció is a véleményszabadság része lett, nem is volt már választható alternatíva, de azért kell mégis külön leszögezni, mert a kereskedelmi szólások tekintetében Post a szólásszabadság érintettségének (hatályának) kérdését más értékre, a demokratikus kompetenciára, informáltságra (democratic competence) vezeti vissza. ${ }^{14}$ Azok a kommunikatív aktusok, amelyek pusztán ez utóbbi alapján tartoznak a hatály alá, más megítélés és jogi rezsim alá tartoznak, mint a szólásszabadság demokratikus legitimációt biztosító alapvető köre. Fontos tehát látni, hogy Post számára a véleményszabadság már abban a tartományában is lényegesen szélesebb kört fog át a szüken értelmezett közéleti megszólalásoknál, amely a demokratikus legitimáció szempontjából nélkülözhetetlen. A közélet demokratizmusát biztosító társadalmi párbeszédben az emberek lényegesen sokszínübben vesznek részt, a nyilvánosságnak szánt közölnivalóik sokkal szerteágazóbbak, mint a tisztán vagy legalábbis közvetlenül politikai megnyilvánulások. ${ }^{15}$

\subsection{A szólásszabadság központi magja}

Az iménti áttekintésből világosan látható, hogy a szólásszabadság még a „közéletcentrikus", vagyis a demokratikus állami és társadalmi berendezkedés követelményei felől közelítő elmélet fősodorja számára is lényegesen többet jelent, mint a szűken

\footnotetext{
${ }^{12}$ Robert C. Post: The Constitutional Concept of Public Discourse: Outrageous Opinion, Democratic Deliberation, and Hustler Magazine v. Falwell. 103 Harvard Law Review 601 1989-1990

${ }^{13}$ Robert C. PosT: Participatory Democracy as a Theory of Free Speech. 97 Virginia Law Review 477

${ }^{14}$ Post (11. lj.)

${ }^{15}$ Ez alapján Jack Balkin már tovább is fejlesztette Post elméletét, és a szólásszabadság célját a diskurzus kulturális kereteinek szabadságában azonosította: Jack M. BALKIN: Cultural Democracy and the First Amendment. 110 Northwestern University Law Review 10532016
} 
értelmezett közügyek megvitatásának kötetlenségét. Érdemes ráadásul kiemelni, hogy az említett teoretikusok - Bork kivételével - ezt a szélesebb hatályt annak az amerikai megközelítésnek a jegyében dolgozták ki, amely a hatályon belüli közléseknek rendkívül erős, adott esetben abszolút védelmet igyekszik biztosítani. Post elméletének köszönhetően ebben a logikában a kereskedelmi szólások doktrínába vonása sem jelent törést, hiszen az eltérő mögöttes értékekre (demokratikus legitimáció, illetve demokratikus informáltság) hivatkozással határozottan elkülönítendők egymástól a hatály alá eső szólások csoportjai.

Bár mindehhez képest a szólásszabadság európai és magyar doktrínája sok tekintetben más utat jár, az elméleti keretek megrajzolásakor rengeteget meríthetünk az eddig felhozott megfontolásokból. Ez mindenekelőtt azért van így, mert a magyar Alkotmánybíróság judikatúrájára tekintve azt állapíthatjuk meg, hogy az leginkább a demokratikus igazolásokhoz illeszkedik. Az előző fejezetben arra jutottunk, hogy a szólások alkotmányos alapértékét mindenekelőtt a nyilvános társadalmi kommunikációban való részvétel adja. Bár a határozatok érvelésében hangsúlyosan van jelen a véleményszabadság individualista megalapozásának hagyománya, sőt még az igazság keresésének említésére is akad példa, a doktrína legátfogóbban a demokratikus igazolás alapján, azon belül is a részvételi modell elméleti szempontjaival magyarázható.

A magyar doktrína a kereskedelmi kommunikációt is ebben a logikában vonja a véleményszabadság hatálya alá. A hazai gyakorlatban - szemben Postnak az amerikai esetjogot feldolgozó teóriájával - nem találunk elkülöníthető értéket, amely a gazdasági reklámok alkotmányos értékét másként ragadná meg a többi közléshez képest. A demokratikus nyilvánosság csatornáin sugárzott, a társadalom megszólítását célzó kereskedelmi üzenetek a közösségi párbeszéd részei, így - részben akár a közéleti tartalmakhoz füződő sajátos, később elemzett kapcsolatuktól függetlenül is számításba jönnek a szólásszabadság számára. Éppúgy, mint minden más szólás, amely a nyilvánosság megszólítására törekszik.

A véleményszabadság hatálya alá tartozó közlések azonban korántsem ugyanazzal az erővel jönnek számításba, mivel nem azonos módon állnak kapcsolatban az igazolás alapvető értékével. A magyar doktrína szilárd tétele, hogy a közügyekkel összefüggő vélemény kinyilvánításának szabadsága a szólásszabadság legbelső védelmi köréhez 
tartozik, amelynek korlátozására a legszűkebb körben nyílik alkotmányos lehetőség. ${ }^{16}$ Az Alkotmánybíróság ennek a tételnek újból és újból következetesen érvényt szerez, vagyis a doktrína gyakorlati szempontból is kulcsfontosságú elvéről van szó. Az esetjogból teljesen egyértelmü, hogy bár a szólásszabadság hatálya a demokratikus nyilvánosságban megjelenő valamennyi közlésre kiterjed, a védelem körében lényegi különbségek vannak a megszólalások alkotmányos pozíciói között. Világosan kirajzolódik a kép, hogy a szólásszabadságnak van egy központi magja, amelyre más mércék vonatkoznak, mint a védelem külsőbb rétegeire, és ahol a szólásszabadság mellett szóló alkotmányjogi megfontolásokat különös szigorral kell érvényre juttatni.

E helyütt most pusztán azt próbálom minél jobban körbejárni, hogy miként ragadhatjuk meg a közügyek vitájának kategóriáját, azaz miként határozhatjuk meg a szólásszabadság „központi magját”. E definíciós feladat elvégzése után érdemes csak azzal a kérdéssel foglalkozni, hogy pontosan milyen mércéket tartunk mérvadónak e körön belül és kívül.

\section{Gyakorlati tesztek nyomában}

Tekintettel arra, hogy a szólásszabadság által nyújtott védelem valamennyi jogág esetében lényegesen különbözik a közügyek vitáján belül és kívül, alapvető jelentőséggel bír, hogy a társadalmi párbeszédbe belépő - és ezzel alkotmányos relevanciával bíró - közlések közül melyeket soroljuk ebbe a körbe. Komoly gyakorlati következményekkel járó kérdéseknél mindig csábító a gondolat, hogy világos, egyértelmü, praktikusan alkalmazható határok megvonására törekedjék az ember. Az alábbiakban ezzel szemben amellett érvelek majd, hogy a közéleti beszéd vonatkozásában ezt a gyakorlatorientált törekvést - bár fontos hangsúlyokra mutathat rá - összességében nem koronázhatja siker, ezért a legfontosabb kérdéssé döntésünk helyes „tájolása” válik, vagyis az, hogy helyesen azonosítjuk és tartjuk-e szem előtt a releváns mögöttes értékeket.

Mindenekelőtt számba kell vennünk, hogy a magyar Alkotmánybíróság gyakorlatában milyen gyakorlati teszteket találunk a közvita határának megrajzolására. Vizsgálatunkat jelentős mértékben gazdagítja, ha az alkotmányjogi panaszok nyomán

\footnotetext{
${ }^{16}$ Összefoglalóan lásd 7/2014. (III. 7.) AB határozat és 13/2014. (IV. 18.) AB határozat
} 
megvizsgált konkrét ügyekben egyelőre még kisebb merítésű magyar judikatúra mellett az Emberi Jogok Európai Bíróságának (EJEB, strasbourgi bíróság) gazdag esetjogát is áttekintjük, amire annál inkább sort keríthetünk, mivel az Alkotmánybíróság az alábbi kérdésekben mérvadó fórumként tekint és rendszeresen hivatkozik a strasbourgi bíróságra. ${ }^{17}$ Bár az alábbi témakörök sok egyéb érdekes problémát is felvetnek, mi most kizárólag egyetlen kérdéssel foglalkozunk: milyen következtetések vonhatók le belőlük a közügyek vitájának definiálására nézve. ${ }^{18}$

\subsection{Közszereplői státusz}

A kérdéskör nagy klasszikusa a közszereplöket érő bírálatok megítélésének kérdése. A bírói fórumok e körben érezték elöször szükségesnek, hogy sajátos teszteket dolgozzanak ki azokra a megszólalásokra, amelyek különös erővel kötődnek a közösségi diskurzushoz. Úgy is fogalmazhatunk, hogy ez a kérdéskör tekinthető a közügyek vitájára vonatkozó doktrína bölcsőjének.

A kiindulópont világos és egyértelmű volt: az a szólás, amely közhatalmat gyakorló politikus közéleti tevékenységére vonatkozik, különösen védett politikai véleménynyilvánításnak számít, ahol a személyiségvédelem általános szabályainak háttérbe kell szorulniuk. Az Alkotmánybíróság által is precedensértékűként hivatkozott EJEB-döntés, a Lingens kontra Ausztria ügyben hozott ítélet szerint az osztrák kancellár nem kifogásolhatja az őt kancellári minőségében ért, személyeskedő és felfokozott jelzőkkel tarkított lesújtó véleményt. A politikusok elképzeléseiről és tevékenységéről folytatott robosztus nyilvános vita a demokratikus társadalom alapvető ismérve, amelyet erős bástyákkal kell védeni. ${ }^{19}$ A Lingens-ügy kiindulópontját a megfogalmazott tétel alkalmazási körének következetes és markáns bővítése követte. A joggyakorlat elöbb egyértelmüvé tette, hogy a közügyekkel összefüggésben kifejtett vélemények fokozott védelme nem korlátozódik a politikusok bírálatára és a szüken értelmezett politikai vitákra. A Thorgeirson kontra Izland ügy

17 KolTay András: A közéleti szereplök hírnévvédelme a strasbourgi Emberi Jogok Európai Bíróságának gyakorlatában. Jogtudományi Közlöny 2008/2.

${ }^{18} \mathrm{Az}$ idevágó strasbourgi gyakorlat más kérdésekre (is) fókuszáló áttekintésére lásd a közelmúltból pl.: TóTH J. Zoltán: A defamatorikus deliktumokkal kapcsolatos részes állami büntetöbirósági döntések megitélése a strasbourgi bíróság gyakorlatában. In: KOLTAY András - TÖRÖK Bernát (szerk.): Sajtószabadság és médiajog a 21. század elején 4. Wolters Kluwer, Budapest, 2017. 309-423.

${ }^{19}$ Lingens kontra Ausztria (9815/82), 1986. július 8., 42-47. bekezdések 
rávilágított arra, hogy a hatóságok munkáját ért kritika, úgymint a rendőri brutalitást számon kérő vélemény határai szintén tágabbak. A strasbourgi bíróság nem látta indokoltnak, hogy a fokozott védelem körét csupán a nyilvánosság előtt leghevesebben vitázó politikusok személyén keresztül jelölje ki, és noha a hatóságok bevonása természetesnek tünik, a döntés indokolása már elöre jelezte, hogy a bíróság ennél általánosabb jelleggel sem látja szétválaszthatónak a politikai és a közügyeket érintő egyéb viták kategóriáját. ${ }^{20}$ A kérdés összetettségét ugyanakkor jól mutatja, hogy az EJEB joggyakorlatának szempontrendszere még a közhatalmat gyakorlók körén belül is figyelemmel van további körülményekre: bár a kritika lehetőségének mindegyikük esetében tágabbnak kell lennie, nem feltétlenül kell elérnie a politikusokra irányadó mértéket. $^{21}$ Ezzel összhangban az EJEB tekintetbe veszi például, hogy az igazságszolgáltatás szereplöi, kiváltképp a bírák sérülékenyebbek a személyüket ért bírálatok esetén, ezért rájuk eltérő tesztek alkalmazhatók. ${ }^{22}$

A számunkra most talán legtanulságosabb értelmezés azonban először a Bladet Tromsø és Stensaas kontra Norvégia ügyben fogalmazódott meg. A perbe vont újságírók a fókavadászok kegyetlenségéről készített anyagukban nem is közszereplőkre, hanem magánszemély halászokra nézve fogalmaztak meg súlyos kritikát. A strasbourgi bíróság, miután elismerte a bírálat súlyos és részben becsületsértő jellegét, az eset körülményeiből összességében arra következtetett, hogy a fókavadászok személyiségvédelme nem állhat az egyértelműen közérdekű vita útjába. ${ }^{23}$ Legkésőbb ennél az ügynél világossá vált tehát, hogy az EJEB gyakorlatában a közügyek vitájának meghatározásakor nem old meg mindent az a körülmény, hogy politikust vagy közhatalom gyakorlóját érinti-e a heves bírálat. Erről annál inkább nem beszélhetünk, mivel az esetjogban arra is találunk példát, amikor közszereplő politikus is sikerrel hivatkozhatott a személyiségvédelem általános sztenderdjeire, kifogásolva a bíráló szavak felfokozottságát. A Tammer kontra Észtország ügyben a miniszterelnök korábbi tanácsadója (és szeretője) annak ellenére nem volt köteles türni a magánéletére vonatkozó véleménynyilvánításokat, hogy kormányzati pozíciója után is aktív alakítója maradt a pártpolitikának. A közszereplöi státusz nem adott felmentést a politikust magánszemély (többek között anyai) minőségében illető bírálat hevességére. ${ }^{24}$ Ehhez

\footnotetext{
20 Thorgeirson kontra Izland (13778/88), 1992. június 25., 64. bekezdés

${ }^{21}$ Thoma kontra Luxembourg (38432/97), 2001. március 29., 47. bekezdés

${ }^{22}$ De Haas és Gijsels kontra Belgium (19983/92), 1997. február 27., 37. bekezdés

${ }^{23}$ Bladet Tromsø és Stensaas kontra Norvégia (21980/93), 1999. május 20., 73. bekezdés

${ }^{24}$ Tammet kontra Észtország (41205/98), 2001. február 6., 66-70. bekezdések
} 
képest még egy további csavar a témában a Von Hannover kontra Németország (no. 2) ügyben született ítélet, amely szerint a közéleti szereplők, különösen a politikusok tekintetében az is előfordulhat, hogy nem is csupán magával a közszerepléssel, hanem az érintett magánéletével kapcsolatban is figyelembe kell venni a közvélemény tájékozódáshoz való jogát. ${ }^{25}$

A magyar Alkotmánybíróság gyakorlatára térve mindenekelőtt két olyan döntést kell szemügyre vennünk, amely absztrakt utólagos normakontroll eljárásban született meg. Annak ellenére, hogy ezek a határozatok konkrét tényállás megítélésének pontosságával értelemszerüen nem tudnak szolgálni, mégis kibontható belölük a számunkra lényeges problematika. A korábbi alkotmány hatálya alatt fejlődő több mint két évtizedes joggyakorlatot leginkább az a döntés határozta meg, amely a hatóság vagy hivatalos személy személyiségének büntetőjogi védelmével foglalkozott. A 36/1994. (VI. 24.) AB határozat egyfelöl a vizsgált kérdéskör határain belül maradva csak a közhatalmat gyakorló személyekkel és intézményekkel, valamint a közszereplő politikusokkal kapcsolatos véleménynyilvánításra nézve fogalmazott meg alkotmányos mércét. Másfelől azonban az indokolás mondataiból kitünik, hogy az Alkotmánybíróság a közszereplőket ért bírálatot csupán a kérdéskör kiindulópontjának tekinti, és a közügyek vitája, vele együtt a szólásszabadság fokozott védelmének köre ennél biztosan szélesebb kategória. Nemcsak arról van szó, hogy a testület a „közügyeket érintő véleménynyilvánítás” kifejezéssel él a szövegben, hanem arról, hogy miben ragadja meg döntésének fö motívumát: mivel a demokratikus társadalom létezésének és fejlődésének nélkülözhetetlen eleme a közügyek vitatása, ezért kiemelkedő alkotmányos érdek füződik ahhoz, hogy a polgárok bizonytalanság, megalkuvás és félelem nélkül vehessenek részt a politikai és társadalmi folyamatokban, a közéletben. ${ }^{26}$ Ehhez nyilván elengedhetetlenül szükséges a közszereplők bírálhatóságának kötetlensége, de az alkotmányos célkitüzés eléréséhez sokkal többre van szükség.

A közszereplői mivolt középpontba állításának elégtelenségét teljesen nyilvánvalóvá tette az Alaptörvény hatálybalépését követően hozott 7/2014. (III. 7.) $A B$ határozat. A Polgári Törvénykönyvnek a közszereplök bírálhatóságára vonatkozó rendelkezését vizsgáló döntés a korábbi alkotmány alatt kidolgozott érvekre építve,

\footnotetext{
${ }^{25}$ Von Hannover kontra Németország (no. 2) (40660/08 és 60641/08), 2012. február 7., 110. bekezdés

${ }^{26}$ 36/1994. (VI. 24.) AB határozat, Indokolás III.1., ABH 1994, 219, 229.
} 
azokat továbbfejlesztve próbálta meg helyükre tenni az alkotmányos hangsúlyokat. A tisztázás szerint a közügyek vitájára vonatkozó védelem fókuszában elsődlegesen nem az érintett személyek státusza áll, hanem az, hogy a megszólaló valamely társadalmi, politikai kérdésben fejtette ki nézeteit. A fokozott védelemre irányadó szempontok így egyfelöl tágabb körben irányadók, mint a közhatalom gyakorlóit vagy a hivatásszerüen közszereplést vállalókat érintő bírálatok köre, másfelöl nem vonatkoznak a közszereplőket illető, de közügyekkel kapcsolatban nem álló véleményekre. Félreértés ne essék: nyilvánvaló, hogy a közéleti szereplökre vonatkozó beszéd továbbra is a legvédettebb kör központi alkotóeleme, de nem jelöli ki számunkra a szólásszabadság e fontos kategóriájának határait. ${ }^{27}$

A magyar doktrína tehát már a közszereplőket érintő véleménynyilvánításokkal kapcsolatos absztrakt normakontroll eljárások eredményeképpen megfogalmazta a strasbourgi gyakorlatban is kimunkált és a magyar irodalomban is megjelenő ${ }^{28}$ tézist, miszerint a bírált személy státusza korántsem ad a kezünkbe mindent elrendező tesztet a közügyek vitájának meghatározásakor. Kétség nem férhet hozzá, hogy meghatározó szempontja marad az alkotmányos vizsgálatnak, de nem építhetünk csak rá. Az Alkotmánybíróság az alkotmányjogi panasz nyomán elé került konkrét tényállást később már ennek figyelembevételével, általánosabb tesztet keresve igyekezett értékelni, ${ }^{29}$ amire ezért később térünk majd vissza.

\subsection{Kereskedelmi érdek}

Hasonló eredményre jutunk, ha annak a kérdésnek eredünk a nyomába, hogy megbízható gyakorlati tesztre támaszkodhatunk-e, amikor gazdasági, kereskedelmi érdeket tudunk azonosítani az előttünk fekvő ügyben. Biztos kézzel diszkvalifikálhatjuk-e a kereskedelmi érdektől nem mentes közléseket a közügyek köréböl? Ha igen, akkor ezek a közlések - még ha a szólásszabadság hatálya alatt maradhatnak is, de - nem számíthatnának komolyabb védelemre. A válasz azonban nemleges.

${ }^{27}$ 7/2014. (III. 7.) AB határozat, Indokolás [47]-[48]

${ }^{28}$ SZABÓ Máté Dániel: Nyilvános magánszféra - hol a határ? In: Ünnepi kötet Sári János egyetemi tanár 70. születésnapja tiszteletére. Budapest, Rejtjel Kiadó, 2008; KolTAY András: A szólásszabadság alapvonalai. Budapest, Századvég, 2009. 422.

${ }^{29}$ Lásd 13/2014. (IV. 18.) AB határozat 
Az EJEB esetjoga főszabályként régóta képviseli a tételt, hogy a kereskedelmi érdeket hordozó megszólalások nem számíthatnak a közvitára vonatkozó érvek támogatására. A Markt Intern Verlag Gmbh és Klaus Beermann kontra Németország ügyben a bíróság nem talált egyezménysértőnek egy kiadóvállalatot (markt intern) sújtó elmarasztalást, amiért az az egyik kiadványában egy kozmetikai nagyvállalat üzleti tevékenységét sokadik alkalommal bírálva a cégre sérelmes információkat tett közzé. Az indokolás szerint az érintett nagyvállalatok érdekeit sértő cikk közzétételére kereskedelmi kontextusban, piaci szereplöknek címezve került sor, így összességében nem volt helye a közérdekü vitára és a sajtó fokozott védelmére vonatkozó szempontok érvényesítésének. ${ }^{30}$ A Jacubowski kontra Németország döntés tanúsága szerint pedig akár az újságírók sem számíthatnak az egyezmény szigorúbb védelmére, ha a gazdasági vitához kapcsolódó közlésük mögött az ügyfélszerzés szándéka sejlik föl. Az EJEB következetesen hangoztatott értelmezése szerint a hatóságoknak szélesebb mozgásterük van a kereskedelmi szólások szankcionálására, különösen az olyan összetett kérdések, mint a tisztességtelen üzleti magatartások megítélése terén. ${ }^{31}$ Hasonlóképpen hangoztatta a bíróság az autópiaci történésekre fókuszáló müsorszolgáltató kereskedelmi motivációjának jelentőségét a Demuth kontra Svájc ügyben, megerősítve, hogy a gazdasági kommunikáció korlátozását enyhébb mérce alapján ítéli meg. ${ }^{32}$

A strasbourgi bíróság elé került további ügyek ugyanakkor világosan rámutatnak arra, hogy a közlések közügyekhez kötődő jellegének összetett megítélésekor a gazdasági, kereskedelmi érdek vagy érintettség korántsem válhat önmagában perdöntővé. A Hertel kontra Svájc ügyben az EJEB annak ellenére a közügyek vitájára vonatkozó érvek alapján döntött, hogy Hertel úr sajtóban terjesztett kutatói következtetése, mely szerint a mikrohullámú sütők használata súlyos egészségkárosító és rákkeltő hatással jár, a bíróság megállapítása szerint negatív hatással lehetett a mikrohullámú sütők eladására és az érintett cégek üzletpolitikájára. Mivel azonban álláspontja közérdekü kérdésben fogalmazódott meg, ezért még úgy is méltó volt a fokozott védelemre, hogy egyébként tudományos bizonyosságra nem támaszkodhatott. ${ }^{33}$ A Barthold kontra Németország ügyben szintén nem volt kétséges,

\footnotetext{
${ }^{30}$ Markt Intern Verlag Gmbh és Klaus Beermann kontra Németország (10572/83), 1989. november 20-i ítélet

${ }^{31}$ Jacubowski kontra Németország (15088/89), 1994. június 23., 25-26. bekezdések

${ }^{32}$ Demuth kontra Svájc (38743/97), 2002. november 5-i ítélet, 41-42. bekezdések

${ }^{33}$ Hertel kontra Svájc (25181/94), 1998. augusztus 25-i ítélet, 47-50. bekezdések
} 
hogy a perbe vont hamburgi állatorvos a saját éjszakai praxisára nézve előnyös, állatorvos kollégáira nézve azonban korántsem hízelgő véleményének adott hangot a sajtóban, a bírák mégis arra helyezték a hangsúlyt, hogy a Barthold urat szerepeltető cikk a nyilvánosság tájékoztatását célozta a hamburgi állatorvosi ellátásról, így a közlésnek a megszólalóra nézve kedvező, míg a versenytársakra nézve hátrányos, üzleti jellegü hatása nem perdöntő. ${ }^{34}$ A Stambuk kontra Németország ügy hasonló kérdéseket vetett föl. Stambuk doktor azzal érdemelte ki a hatósági bírságolást, hogy lézertecnikával végzett szemmütétjeiröl egy újságnak részletes ismertetést adott, amely végül az orvosokra vonatkozó reklámtilalmat sértő, Stambuk úr praxisát jelentős mértékben népszerüsítő cikket eredményezett. Az EJEB érvelése a panaszosnak nem túl sok jót ígérő módon indul: az indokolás kifejti, hogy a félrevezető reklámoknak a tisztességes versenyt szolgáló általános korlátozhatóságán túl egyes üzleti tevékenységek és foglalkozások esetében - mások jogainak védelmében - akár még a valós információk is korlátok közé szoríthatók. Az orvosok nyilvános kommunikációját érintő korlátozások tipikusan ebbe a körbe tartoznak. A baljós kezdet után az ügy mégis Stambuk doktor sikerével zárult, mivel az EJEB ez esetben is további körülményeknek tulajdonított meghatározó jelentőséget, így annak, hogy a szóban forgó újságcikk egy közérdeklődésre számot tartó egészségügyi témában tájékoztatta a nyilvánosságot. ${ }^{35}$

Ami a strasbourgi gyakorlatot szem előtt tartó magyar doktrína alakulását illeti, az Alkotmánybíróság alaptétele kezdettől fogva - vagyis a 1270/B/1997. AB határozat óta - szintén az, hogy a kereskedelmi jellegü információk közzétételekor szélesebb körü állami beavatkozás lehet alkotmányosan indokolt. A testület ezzel összhangban a gazdasági reklámozást érintő korlátozásokat szinte kivétel nélkül alkotmányosnak ítélte eddigi gyakorlatában. Így tett a személyhez füződő jogok sajátos védelme, ${ }^{36}$ a szexuális szolgáltatások, illetve a dohány- és alkoholtermékek kiterjedt korlátozása, ${ }^{37}$ továbbá a médiatartalmakban elhelyezett kereskedelmi kommunikáció szabályozása ${ }^{38}$ esetén. Számunkra azonban most nagyobb jelentőséggel bír a kereskedelmi szólások disztingvált megközelítését tükröző 23/2010. (III. 4.) AB határozat. Ez mindenben fenntartotta a korábbi tételeket, de nagy figyelmet érdemlő kiegészítéseket füzött

\footnotetext{
${ }^{34}$ Barthold kontra Németország (8734/79), 1985. március 25-i ítélet

${ }^{35}$ Stambuk kontra Németország (37928/97), 2002. október 17-i ítélet

${ }^{36}$ 1270/B/1997. AB határozat

${ }^{37} 37 / 2000$. (X. 31.) AB határozat és 23/2010. (III. 4.) AB határozat

${ }^{38} 165 / 2011$. (XII. 20.) AB határozat
} 
hozzájuk. Az Alkotmánybíróság hangsúlyozta, hogy a gyengébb alkotmányos védelemben részesülő kereskedelmi szólást a kizárólagos, illetve meghatározó gazdasági érdek különbözteti meg más közlésektől, ugyanakkor a közlésekhez kötődő gazdasági érdek súlyának megítélésében már nehézségek adódhatnak. A kereskedelmi kommunikáció ugyanis összefonódhat a közügyek vitatásával vagy a müvészi önkifejezéssel, és a gazdasági jogalanyok megszólalásai kifejezhetnek a közügyekben releváns állásfoglalást, véleményt. Továbbá a kulturális, müvészeti, vagy akár közéleti tartalommal bíró javak is megjelennek reklámozott áruként, szolgáltatásként. Az Alkotmánybíróság ráadásul mindehhez azt is hozzátette, hogy az óhatatlanul előforduló határesetekben a vélelem amellett szól, hogy a közlés a gazdasági érdekeken túlmutató értékeket szolgál. ${ }^{39}$ A határozat a vizsgált kérdések közül az egyiknél éppen e logika alapján lépett föl a reklámkorlátozó szabály ellen.

Későbbi következtetéseink levonása szempontjából talán még nagyobb jelentőséggel bír az a közelmúltbeli ügy, amelyben a bírósági döntést támadó alkotmányjogi panasz a gazdasági érdeket érintő szólások kérdésével a reklámozás világán kívül szembesítette az Alkotmánybíróságot. A 3/2015. (II. 2.) AB határozat sajtótermékre kivetett piacfelügyeleti bírsággal kapcsolatos ügyben született, miután a gazdasági-pénzügyi kérdésekkel foglalkozó hírportál cikkét a hatóság a valós információk ellenére spekulatívnak minősítette, amely az érintett cég (MOL Zrt.) tőzsdei papírjaira nézve tiltott piacbefolyásolást valósított meg. Az Alkotmánybíróság, bár elismerte a piacbefolyásolás tilalmának alkalmazhatóságát sajtócikk közzétételére, a vizsgált ítéletben foglalt törvényértelmezés szúkítésére szorította a bíróságot. Iránymutatása szerint a tőkepiaci törvényt e körben úgy kell értelmezni, hogy az ne tartsa vissza a sajtót az egyébként valós információk nyilvánosságra hozásától. Az alkotmánybírósági érvelés központi eleme szerint az ügy - a részvényekre gyakorolt esetleges hatása ellenére - a szólás- és sajtószabadság fokozottan védett körébe, a közügyek megvitatásához tartozik, ezért a bírósági ítéletben foglaltaknál szigorúbb alkotmányossági vizsgálatnak és szorosabb törvényértelmezésnek van helye. ${ }^{40} \mathrm{Az}$ ügy gazdasági érintettsége tehát ez esetben hangsúlyozottan nem járt azzal a következménnyel, hogy az Alkotmánybíróság a kereskedelmi szólásokra vonatkozó alacsonyabb korlátozási teszteket alkalmazta volna. Perdöntővé éppen a közvitához tartozás vált: a testület a vizsgált ítéletet megsemmisítette.

\footnotetext{
${ }^{39}$ 23/2010. (III. 4.) AB határozat, Indokolás IV.4.1., ABH 2010, 101, 122.

40 3/2015. (II. 2.) AB határozat, Indokolás [24]-[27]
} 
Mindezek nyomán kijelenthetjük, hogy bár az esetjogban egyértelmü tétel a kereskedelmi szólások kevésbé szigorú védelme a szólásszabadság alapján, a közszereplői státuszhoz hasonlóan a gazdasági érdek, érintettség vagy kihatás sem ad a kezünkbe mindenható tesztet a közügyek vitájának meghatározásakor. Lényeges szempontja marad a vizsgálatnak, ám végső döntésünk meghozatalakor mégsem ennek a kritériumnak kell szemünk elött lebegnie.

\subsection{Irodalom, müvészet}

Bár a magyar Alkotmánybíróság gyakorlatából keveset tudunk majd meríteni ebben a körben, mégis érdemes külön foglalkoznunk azzal a kérdéssel, hogy vajon egyértelmü besorolást jelent-e a közügyekhez kötődés szempontjából (akár negatív, akár pozitív választ indikálva), ha egy szólás művészeti, irodalmi alkotás formáját ölti. Több okból is fontosnak látom, hogy - ha a témánkhoz kötődő rövidséggel is, de érintsük ezt a kérdést. Egyrészt, amint láttuk, a véleményszabadság közéletcentrikus teoretikusainak (Meiklejohn, Kalven, Bork) vitái jelentős részben éppen a körül forogtak, hogy hogyan írható le a szólásszabadság és a müvészeti alkotások viszonya. Másrészt ha el akarjuk helyezni a közügyek vitájának kategóriáját a magyar doktrínában, akkor konkrét vonatkozó esetjog hiányában is érdemes kísérletet tennünk e viszony megragadására, mivel enélkül túlságosan nagy területet hagynánk teljes homályban. Harmadrészt pedig jelen vizsgálatunk értékes szempontokat ad annak a fontos elméleti kérdésnek a megválaszolásához is, hogy a magyar Alaptörvényben külön nevesített müvészeti alkotás szabadsága mennyiben rendelkezik önállósult alkotmányjogi tartalommal a véleménynyilvánítás jogához képest. Mivel az Alkotmánybíróság gyakorlatából itt az eddigieknél kevesebb kapaszkodót találunk majd, a releváns szempontok felvillantásához különösen is érdemes fogódzókat keresnünk az EJEB esetjogában.

Az Emberi Jogok Európai Egyezménye a müvészet szabadságát nem nevesíti külön jogként, így a strasbourgi gyakorlat a müvészeti alkotásokat érintő korlátozásokat tisztán a véleménynyilvánítás szabadsága alapján ítéli meg. Számunkra most a Müller és mások kontra Svájc ügy szolgálhat kiindulópontként, ahol a bíróságnak obszcén embereket és állatokat egyaránt szerepeltető szodómiát és fellációt ábrázoló - 
festmények miatt alkalmazott bírságról és elkobzásról kellett döntenie. Az EJEB a szigorú szankciókat sem találta egyezménysértőnek, amiben kétségkívül szerepe volt annak a későbbiekben is hangoztatott szempontnak, hogy egységes európai mérce híján a bíróság a közerkölcsöt érintő kérdések megítélésében a szokásosnál szélesebb mozgásteret enged a nemzeti hatóságoknak. Az indokolásból és a későbbi gyakorlatból azonban az is kiderül, hogy az engedékenység nem csak ennek tudható be. Az ítélet indokolását érdekes kettősség jellemzi: egyfelől leszögezi, hogy a művészeti alkotások létrehozása és bemutatása a demokratikus társadalomban elengedhetetlen gondolat- és véleménycsere része, másfelől azonban nem hívja föl a szólásszabadság legszigorúbb védelmére felszólító, a közügyek vitájának kötetlenségét óvó érveket. Elképzelhető, hogy a bíróság a közerkölcs melletti érveknek ebben az esetben mindenképp teret engedett volna, de ettől függetlenül tény: nem emelte a tétet a szólásszabadság „legerősebb csapatainak harcba küldésével”. 41

Hasonló érvelést figyelhetünk meg a müvészeti szabadság egy érdekes strasbourgi esetkörén belül, a blaszfémiával kapcsolatos ügyekben. Az Otto-Preminger-Institut kontra Ausztria ügyben a bíróság szintén a szólásszabadság komoly korlátozását találta indokolhatónak, amikor nem ítélte egyezménysértőnek a - Szentháromságon és Szűz Márián való gúnyolódásával - mások vallási meggyőződését sértő film művészmoziban történő vetítésének előzetes megtiltását és a film kópiáinak a jövőbeli vetítéseket is ellehetetlenítő elkobzását. Az EJEB itt sem hivatkozott a közvita kiemelkedő védelmének szükségére, sőt az indokolásban kifejezetten arra utalt, mintha az ily módon sértő közléseket eleve nem tekintené olyannak, amelyek hozzájárulnak a közügyek vitájához. ${ }^{42}$ A bíróság a Wingrove kontra Egyesült Királyság ügyben pedig az eddigieknél is kevesebb homályt hagyott a most vizsgált kérdésben. A nemzeti hatóságok ez esetben is amellett döntöttek, hogy nem teszik lehetővé az Avilai Szt. Teréz erotikus képzelgéseit ábrázoló video forgalmazását. Az EJEB az indokolásban ezúttal világosan utalt rá, hogy az ügyben nem látja indokoltnak az addigra már egyre több ügyben felmerült szigorú közvita-teszt alkalmazását, ami újfent a szólásszabadság jelentős korlátozásának érintetlenül hagyásához vezetett. ${ }^{43}$ Mindezek után az I.A kontra Törökország ügyben hozott döntés azért érdemel még kiemelést, mert ott az eddigieknél talán még élesebben merülhetett volna föl a büntető elmarasztalásra vezető

\footnotetext{
${ }^{41}$ Müller és mások kontra Svájc (10737/84), 1988. május 24-i ítélet, 33. bekezdés

${ }^{42}$ Otto-Preminger-Institut kontra Ausztria (13470/87), 1994. szeptember 20-i ítélet, 49. bekezdés

${ }^{43}$ Wingrove kontra Egyesült Királyság (17419/90), 1996. november 25-i ítélet, 58. bekezdés
} 
könyv társadalmi vitákhoz kötődő jellege. A filozófiai és teológiai nézeteit irodalmi stílusban közlő szerző - amellett, hogy müve nem nélkülözte a Mohamed próféta nemi életére tett utalásokat sem - az iszlám vallást és az általa hóbortos agymosottaknak beállított hívőket gúnyolta, akik csupán szánalmas életüket igyekeznek primitív gondolatokkal színesíteni. A strasbourgi bíróság a társadalmi viták védettségére való utalás helyett azt ítélte perdöntőnek, hogy a könyv egyes részei kellő indokul szolgáltak a szankcionáláshoz. ${ }^{44}$

Az eddig bemutatott joggyakorlat tehát azt mutatja, hogy bár az EJEB az irodalmi és müvészeti alkotásokban a demokratikus gondolat- és véleménycsere megnyilvánulásaként a véleményszabadság fontos területét látja, a közléseknek ez a jellege nem jár azzal, hogy a szólásszabadság legvédettebb körébe sorolja őket. A gyakorlatból ugyanakkor természetesen az is világos, hogy a közlés irodalmi, müvészeti megjelenési formája nem is fosztja meg a szólást annak esélyétől, hogy a közügyek vitájához való hozzájárulásnak minősüljön. A Vereinigung Bildender Künstler kontra Ausztria ügyben a bíróság közéleti megnyilvánulásként értékelte azt a festményt, amely az egyik parlamenti párt vezetőjét - többek között Teréz anya, egy osztrák bíboros és párttársai társaságában - szexuális aktus közben ábrázolta. Az EJEB indokolása, elismerve a festmény súlyosan sértő jellegét, a közlést a fokozottan védett szólások körében vizsgálta, és a hatóságok fellépését egyezménysértőnek ítélte. ${ }^{45}$

Érdemes megemlíteni, hogy a Velencei Bizottságnak a szólásszabadság és a vallásszabadság összefüggéseit a blaszfémián keresztül elemző jelentése szintén felhívja a figyelmet a müvészeti alkotások és a közéleti véleménynyilvánítások közti érzékeny határvonal jelentőségére. Eszerint bár a két halmaznak kétségkívül van közös tartománya, a korlátozások megítélésekor nem lehet összemosni öket. ${ }^{46}$

A magyar Alkotmánybíróság elé mind ez idáig nem került olyan ügy, amely a számunkra most releváns kérdésekben a fentiekhez fogható iránymutatást eredményezhetett volna az irodalmi és müvészeti alkotások alkotmányjogi megítélésére nézve. Egy-két általánosabb kiindulópontot mindenesetre találunk a testület döntéseiben, amelyek alapján néhány fontos megállapítást azért

\footnotetext{
${ }^{44}$ I.A. kontra Törökország (42571/98), 2005. szeptember 13-i ítélet

${ }^{45}$ Vereinigung Bildender Künstler kontra Ausztria (68354/01), 2007. január 25 -i ítélet

${ }^{46}$ Report on the relationship between freedom of expression and freedom of religion: the issue of regulation and prosecution of blasphemy, religious insult and incitement ot religious hatred - Adopted by the Venice Commission at its 76th Plenary Session (Venice, 17-18 October 2008), CDL$\mathrm{AD}(2008) 026-$ e., 52.
} 
megfogalmazhatunk arról, hogy hol lehet a helye a müvészetnek a szólásszabadság alkotmányjogi doktrínájában.

Bár a művészet szabadsága a magyar alkotmányos szabályozásban kezdettől fogva önállóan nevesített jog, ${ }^{47}$ a véleménynyilvánítással nyilvánvalóan meglévő szoros kapcsolatát az Alkotmánybíróság korán azonosította. A 30/1992. (V. 26.) AB határozat sokat idézett megállapítása szerint a véleménynyilvánítás szabadsága az ún. „kommunikációs” jogok „,anyajoga”, így tágabb értelemben hozzá tartozik a mủvészi és irodalmi alkotás szabadsága, illetve a múvészeti alkotás terjesztésének szabadsága is. ${ }^{48} \mathrm{Az}$,anyajog” és a külön nevesített jogok kapcsolatára ugyanakkor már nem találunk általános eligazítást az indokolásban, hiszen az további, az érintett jog sajátosságaihoz igazodó összetett kérdés. A későbbi gyakorlat egy fontos tételt mégis megfogalmaz: ahhoz, hogy a véleményszabadság kitüntetett ereje, azaz más jogokkal szembeni elsőbbsége felhívható legyen, a szóban forgó jognak különösen szoros összefüggésben kell állnia az ,anyajoggal”. ${ }^{49}$ Ilyen szoros összefüggést azonosított például az Alkotmánybíróság a vallásszabadság esetében, ${ }^{50}$ és a mủvészeti alkotás szabadságára hivatkozó döntések alapján arra következtethetünk, hogy a szólásszabadság és a müvészetek kapcsolatát hasonló közvetlenség jellemzi. A 24/1996. (VI. 25.) AB határozat a müvészeti alkotások elidegenítés előtti kötelező bírálatát elöíró szabály vizsgálatakor a véleménynyilvánítás és a művészeti élet szabadságának jogát érdemben el sem különítve állapította meg az alkotmányellenességet. A testület a müvészeti szabadság tartalmát a véleményszabadság keretein belül vizsgálta, amit az is jól illusztrál, hogy elvi jellegű utalást tett a strasbourgi bíróság ezirányú értelmezésére. ${ }^{51}$ A $18 / 2014$. (V. 30.) $A B$ határozat a korábbi értelmezéseket az Alaptörvény hatálya alatt is fenntartotta, megerősítette a véleménynyilvánítás és a müvészeti szabadság alkotmányjogi kapcsolatát, és így vezette le a Magyar Müvészeti Akadémia müködésére vonatkozó alkotmányos követelményeket. ${ }^{52}$

\footnotetext{
${ }^{47}$ Lásd előbb az Alkotmány 70/G. § (1) bekezdését („A Magyar Köztársaság tiszteletben tartja és támogatja a tudományos és művészeti élet szabadságát, a tanszabadságot és a tanítás szabadságát."), majd az Alaptörvény X. cikkét („Magyarország biztosítja a tudományos kutatás és művészeti alkotás szabadságát, továbbá - a lehető legmagasabb szintü tudás megszerzése érdekében - a tanulás, valamint a törvényben meghatározott keretek között a tanítás szabadságát.”).

48 30/1992. (V. 26.) AB határozat, Indokolás III.2.1., ABH 1992, 167, 171.

${ }^{49}$ 21/1996. (V. 17.) AB határozat, Indokolás II.1.a), ABH 1996, 74, 76.

${ }^{50}$ 4/1993. (II. 12.) AB határozat, Indokolás I.1., ABH 1993, 48, 51-52.

51 24/1996. (VI. 25.) AB határozat, Indokolás II.1., ABH 1996, 107, 110.

52 18/2014. (V. 30.) AB határozat, Indokolás [11], [13] és [17]
} 
A józan ész intuíciója mellett tehát néhány alapértelmezés is arra utal, hogy a művészeti alkotás szabadságára a véleménynyilvánítással meglévő szoros kapcsolatán keresztül érvényesnek tarthatjuk a szólásszabadság kitüntetett alkotmányos helyére utaló érveket és tételeket. Ez azonban nem azt jelenti, hogy automatikusan vonatkoznának rá a szólásszabadság doktrínájának azok a megfontolásai, amelyeket a bírói fórumok a véleményszabadság legbelső védelmi körében, a közügyek vitájakor alkalmaznak. Éppen erre figyelmeztetnek minket a strasbourgi esetjog példái, illetve a Velence Bizottság megállapításai, és - ha nagyon akarjuk, akkor - a magyar gyakorlatban is találunk erre röpke utalást. Bár az efféle mondatvadászat mindig veszélyes dolog, de mintha a kereskedelmi kommunikáció alkotmányos helyét elemző 23/2010. (III. 4.) AB határozat is épp arra utalna, hogy a kereskedelmi közlések magasabb szintű védelemre törésének két eltérő útja, ha a közügyek megvitatásához kötődnek, illetve ha müvészi önkifejezéssel fonódnak össze. ${ }^{53}$ A két halmaz természetesen fedheti egymást, de ez nem magától értetődő, nem automatikus. Az irodalmi vagy mủvészeti érték felmutatása tehát a közszereplöi státusz vagy a kereskedelmi érdek azonosításához hasonlóan nem jelent perdöntő körülményt egy közlés közérdekü vitához kötődésének meghatározásakor. A müvészeti alkotások, bármilyen fontosak is legyenek a társadalmi párbeszédben, önmagukban még nem tartoznak a közvita dogmatikai körébe. A közlés müvészi jellege a szólásszabadság felöli értékelés fontos szempontja marad, de most keresett fogalmunkhoz, a közügyek vitájához nem visz önmagában közelebb: harmadik egyedi tesztünk sem működtethető tehát automatikusan.

Ezzel el is jutottunk oda, ami számunkra most a továbblépéshez szükséges. Még mielött azonban megnéznénk, hogy egy-egy konkrét szempont kiemelése helyett esetleg milyen általános teszthez fordulhatnánk, egy fontos kérdés lezárásának erejéig maradjunk még az irodalmi, művészeti alkotásoknál. A fentieket olvasva adódik ugyanis a kérdés: ha ezek közül a közlések közül sok egyáltalán nem osztozhat a közéleti vita védettségében, akkor mondhatjuk-e, hogy - bár a kereskedelmi kommunikációnál erősebb alkotmányos védelmet élveznek - nem számíthatnak igazán komoly védelemre. Meggyőződésem szerint erre a kérdésre nemleges választ kell adnunk, ami egyszersmind egy nagyon fontos sajátosságra hívja fel a figyelmünket.

\footnotetext{
${ }_{53}^{53}$ 23/2010. (III. 4.) AB határozat, Indokolás IV.4.1., ABH 2010, 101, 121-122.
} 
Azt állítottam, hogy a szólásszabadság magyar doktrínájának legfontosabb, a jog hatályát is kijelölő alapértéke a demokratikus párbeszéd, amit az is megerősít, hogy a doktrína a közügyek vitájához kötődő közléseket részesíti a legszigorúbb védelemben. Azt is láttuk ugyanakkor, hogy - amint arra az Alkotmánybíróság érvelése újból is újból rámutat - a demokratikus igazolás nem jelent kizárólagosságot, vagyis a szólásszabadság elméletében és gyakorlatában más érték, különösen a személyiség kibontakoztatásának értéke is fontos szerephez juthat. Az irodalmi és müvészeti alkotások védelme pont erre lehet kiváló példa: jóllehet ezek közül több nem részesülhet a közvitához tartozás előnyeiben, fokozott védettségük igazolását az egyéni önkifejezésben betöltött különösen értékes szerepük „,pótolja”. Pontosan ezt érzékelteti a 24/1996. (VI. 25.) AB határozat indokolása, amely a müvészeti élet szabadságának konkrét kibontásakor egyáltalán nem utal a demokratikus társadalmi párbeszéd vagy gondolatcsere fontosságára - ezt a keretet csupán a véleménynyilvánítás szabadságának ,anyajogára” tett utalás rajzolja föl mögöttesen -, helyette a müvészeti alkotómunka szabadságát, a müvész bármely meg nem engedett korlátozástól mentes önkifejezésének alkotmányos értékét hangsúlyozza. ${ }^{54}$ Ennek alapján a művészeti alkotások kiemelkedő alkotmányos jelentősége mellett azzal együtt is megalapozottan érvelhetünk, hogy a szólásszabadság doktrínájának fősodra önmagában nem feltétlenül biztosítaná számukra a kellő körültekintést. Arra pedig épp a közéleti vita jelentőségét elemző 7/2014. (III. 7.) AB határozat is utal, hogy a közéleti véleménynyilvánítás fontosságának hangsúlyozása nem jár azzal, hogy más típusú szólásokra ne vonatkoznának azok a megfontolások, amelyeket az Alkotmánybíróság a véleményszabadság kitüntetett alapjogi helyzetével összefüggésben kifejtett. ${ }^{55}$.

Az irodalmi, művészi kifejezés formáját magára öltő szólás alkotmányos alapértéke tehát mindenekelőtt az egyéni önkifejezés, a müvészi megnyilvánulás kötetlensége, szárnyalása. ${ }^{56}$ Ezzel természetesen nem azt állítom, hogy a művész magának alkot, és alkotómunkájának nincs társadalmi jelentősége, pusztán az igazoló értékek önálló jelentőségére szeretnék rámutatni. Míg a véleménynyilvánítás joga elsődlegesen a demokratikus társadalmi párbeszédben való részvételre fókuszál, és a személyiség kibontakoztatásával szemben erre építi doktrínájának gerincét, addig a szólásszabadság

\footnotetext{
54 24/1996. (VI. 25.) AB határozat, Indokolás II.1., ABH 1996, 107, 110.

55 7/2014. (III. 7.) AB határozat, Indokolás [46]

${ }^{56}$ Sajó András szintén ezt az igazolást látja relevánsnak a müvészi szabadság tekintetében. SAJó András: A szólásszabadság kézikönyve. Budapest, MTA Állam- és Jogtudományi Intézet, 2005. 16.
} 
„anyajogából” fakadó müvészi szabadság már az egyéni önkifejezést helyezi az előtérbe.

Az irodalmi, művészeti alkotások védelme melletti érvelés értelmet, sőt fontos hangsúlyt ad annak az elsőre talán merő formalitásnak tűnő körülménynek, hogy a magyar alkotmányi szabályozás a művészeti alkotás szabadságát önálló jogként nevesíti. Nemcsak arról van szó, hogy egyes elemzések az önálló nevesítést pusztán szimbolikusnak, ${ }^{57}$ vagy akár ,az esztétizálás kísértését” hordozó elkerülendő megoldásnak tekintik, ${ }^{58}$ hanem arról is, hogy a kiemelésnek jelentőséget tulajdonítók is kevéssé fókuszálnak az elkülönítés elvi alapjaira és lényegére. ${ }^{59}$

A fenti elméleti megfontolások kidolgozásában és képviseletében akkor sem lennénk eszköztelenek, ha a müvészeti szabadság nem jelenne meg önállóan nevesített alapjogként az alkotmányszövegben. A szólásszabadság körében releváns többféle érték önmagában véve is engedne annyi mozgásteret, hogy az irodalmi, művészeti alkotások esetében a szokásoshoz képest eltérő módon („sorrendben”) építsünk rájuk. Így például az EJEB, ha kritika éri, amiért védtelenül hagy egy-egy művészi kifejezést, végeredményképpen nem hivatkozhat az önálló jog egyezménybeli megjelenésének hiányára. Az irodalmi, művészeti alkotások védelme melletti, a szólásszabadság dogmatikai fősodrától némiképp eltérő érvelésnek azonban egyértelműen megerősítést, hangsúlyt ad az, hogy a magyar szabályozás a müvészeti alkotás szabadságát önálló jogként nevesíti. Elméleti szempontból mindenképpen tisztább helyzetet jelent, hogy a művészi alkotómunka védelmét - a véleményszabadság kereteibe illeszkedő, de sajátos szempontokra utaló - önálló alkotmányi rendelkezésre tudjuk alapozni. Az Alaptörvény szövege ezzel kifejezi és alátámasztja annak a dogmatikai finomhangolásnak a jelentőségét, amely meg kívánja különböztetni egymástól a szólásszabadság alapjogi és ,,anyajogi” rétegeit.

\footnotetext{
57 Koltay András: Dorian Gray képmásához való jog: a müvészet szabadságának önálló alapjogi jellegéröl. In: KOLTAY András - TÖRÖK Bernát (szerk.): Sajtószabadság és médiajog a 21. század elején 3. Wolters Kluwer, Bp., 2016. 13-95.

${ }^{58}$ Sólyom Péter: A müvészet szabadsága és az esztétikai itéletek. Iustum Aequum Salutare 2007/2. 95109. 109.

${ }^{59}$ CSEPORÁN Zsolt: A müvészet szabadságával élő személyek alapjogi helyzete Magyarországon. In: Kocsis Miklós - TILK Péter (szerk.): A müvészet szabadsága - alkotmányjogi megközelitésben. Kodifikátor Alapítvány, Pécs, 2013. 40-55.; TILK Péter: A müvészet szabadságának szabályozási modellje az Alaptörvényben. In: KoCSIS-TILK (szerk.): A müvészet szabadsága - alkotmányjogi megközelitésben; ZELLER Judit: A tudomány és a müvészet szabadsága. In: CHRONOWSKI Nóra DRINÓCZI Tímea - PETRÉTEI József - TILK Péter - ZELLER Judit: Magyar Alkotmányjog III. - Alapvető jogok. Dialóg Campus, Budapest-Pécs, 2006.
} 
Mindennek a jelentőségét gyakorlati szempontból sem becsülhetjük le, akkor sem, ha egyébként a bírói fórumok judikatúrájában a müvészi szabadságra vonatkozó speciális érvek jelenleg nem nagyon azonosíthatók. ${ }^{60}$ A külön nevesítés - a mögöttes speciális alkotmányi értékkel megerősítve - fontos érveket ad a kezünkbe például annak kijelentéséhez, hogy a strasbourgi bíróság fent röviden bemutatott blaszfémiagyakorlatához képest a magyar doktrína a korlátozás arányosságának sokkal körültekintőbb vizsgálatára szólítja föl a jogalkalmazókat. ${ }^{61}$ Ennek tisztázása után a müvészet iránt aggódók most már nyugodtabban térhetnek vissza a közéleti vita meghatározásának kérdéséhez.

\section{4. Általános teszt nyomában}

Láthattuk, hogy a gyakorlatban felmerülö legfontosabb egyedi szempontok, különös tesztek nem nyújtanak számunkra egyértelmü eligazítást abban a kérdésben, hogy az elöttünk fekvő ügyet a közügyek vitájára vonatkozó legszigorúbb mércével kell-e vizsgálnunk. A következőkben arra keressük a választ, hogy rendelkezésünkre áll-e az eddigieknél összetettebb, az érintett kérdés közérdeküségére általánosan érvényes teszt, amelynek segítségével biztosabb eredményre juthatunk.

Tanulságos mindenekelőtt, hogy a már említett Bladet Tromsø és Stensaas kontra Norvégia ügyben miként jutott az EJEB arra a következtetésre, hogy az egyébként magánszemélyeket (halászokat) kritizáló újságcikkre a közvita mércéit alkalmazza. Az indokolás a vitatott íráson messze túlra tekintve, az újság fókavadászattal régebb óta foglalkozó anyagainak szélesebb kontextusát vizsgálva állapította meg, hogy a közügyek vitájához tartozó ügyről van szó, ráadásul az írás konkrét jellemzőit is felhívva arra következtetett, hogy az újságot nem az érintett magánemberekkel szembeni vádaskodás motiválta. ${ }^{62}$ A Steel és Morris kontra Egyesült Királyság ügy ítélete az értékelés vezérfonalaként hangsúlyozza, hogy az alkalmazandó tesztekről számos körülmény egyidejü mérlegelésével lehet csak döntést hozni. Az egyik gyorsétterem-láncot támadó szórólap kapcsán a bíróság a közlés közérdekű témát

\footnotetext{
${ }^{60} \operatorname{Koltay}(57$. lj.)

${ }^{61}$ TÖRÖK Bernát: Védhetjük-e a vallás(os)okat a blaszfémiától? In: KOLTAY András - TÖRÖK Bernát (szerk.): Sajtószabadság és médiajog a 21. század elején Budapest, Wolters Kluwer, 2014. 187.

${ }^{62}$ Bladet Tromsø és Stensaas kontra Norvégia (21980/93), 1999. május 20., 63. bekezdés
} 
érintő tartalmán túl a közlő személyének, társadalmi szerepének is jelentőséget tulajdonított. ${ }^{63}$ Különösen átfogó elemzésre kerített sort a bíróság a Tønsbergs Blad AS és Haukom kontra Norvégia ügyben, amikor annak adta indokát, hogy a közszereplö gazdasági vezetőt nem közvetlenül e minőségében ért sértő tényállítás miért élvezheti mégis a szólásszabadság kitüntetett védelmét. Az EJEB minden eddiginél hangsúlyosabban szögezte le, hogy a közügyek vitájához tartozás kérdését csakis az érintett téma és a vitatott közlés kontextusának széleskörü értékelésével lehet megválaszolni. A szerephez jutó körülmények változatosságára maga az indokolás szolgál jó példával: ebben az ügyben a bíróság az újságcikket mind „a maga összességében", mind a vitatott részben használt kifejezések egyediségében is mérlegelte, továbbá értékelte a közlés kontextusát, módját és célját, illetve az újságíró jóhiszeműségét. ${ }^{64} \mathrm{~A}$ strasbourgi bíróság későbbi ügyekben is erre a rendkívül összetett tesztre hivatkozik, amelynek alkalmazásával például az Erla Hlynsdóttir kontra Izland ügyben éjszakai szórakozóhelyek tulajdonosainak látszólag magánérdekü vitáját sorolta a bíróság a közügyek közé. Az indokolás megismétli, hogy a közvitához tartozás a téma és a kontextus átfogó vizsgálatát követeli meg, márpedig az újságcikk „a maga összességében” és szélesebb összefüggéseiben az éjszakai szórakozóhelyekre vonatkozó szabályozásról folytatott társadalmi diskurzushoz kapcsolódott. ${ }^{65}$

A strasbourgi esetjog áttekintésekor egy meghatározó tényezőt mindenképpen külön is ki kell még emelni. A fentiek közül a Bladet Tromsø, a Tønsbergs Blad és az Erla Hlynsdóttir ügyek annak a következetes gyakorlatnak is kiváló példái, amely a közügyek vitájához tartozás szempontjából speciális hangsúlyt ad az újságírók és a sajtó közléseinek. Mindenekelőtt a Jersild kontra Dánia ügy indokolására hivatkozva ${ }^{66}$ az EJEB a médiát érintő esetekben kivétel nélkül kulcsfontosságú alapelvként hívja föl a sajtónak a demokratikus társadalomban játszott kiemelkedően fontos szerepét. A gyakorlat egészét tekintve nem tünik túlzásnak kijelenteni, hogy a sajtóban megjelenő közléseknél vélelem szól a közérdeküség mellett. Ez persze nem azt jelenti, hogy a vélelem ne lenne megdönthetö: a Demuth kontra Svájc ügy példája szerint ha az összetett mérlegelés valamelyik eleme - a konkrét esetben az autóipari történésekre fókuszáló televíziós program kereskedelmi célja - különösen erős és egyértelmü érv az

\footnotetext{
${ }^{63}$ Steel és Morris kontra Egyesült Királyság (68416/01), 2005. február 15 -i ítélet, 88., 89., 95. bekezdés

${ }^{64}$ Tønsbergs Blad AS és Haukom kontra Norvégia (510/04), 2007. március 1-jei ítélet, 87. és 90. bekezdés

${ }^{65}$ Erla Hlynsdóttir kontra Izland (43380/10), 2012. július 10-i ítélet, 64. bekezdés

${ }^{66}$ Jersild kontra Dánia (15890/90), 1994. szeptember 23-i ítélet, 31. bekezdés
} 
alacsonyabb fokú védelem mellett, akkor az a médiában megjelenő tartalom értékelésekor is perdöntő lehet. ${ }^{67}$

A magyar Alkotmánybíróság mindezeket a szempontokat - a strasbourgi esetjogra való sürü hivatkozásokkal megerősítve - beemelte a saját gyakorlatába. A 13/2014. (IV. 18.) AB határozatban a testületnek már lehetősége nyílt arra, hogy bírói döntést támadó alkotmányjogi panasszal elé került konkrét tényállás alapján fejtse ki a releváns alkotmányossági követelményeket. A siklósi önkormányzati képviselőnek a polgármester tevékenységét (vezetői stílusát és a közpénzek kezelését) élesen bíráló, a helyi közéleti lapban megjelent cikkét vizsgálva a határozat indokolása nem elégedett meg az érintettek közszereplői státuszának felhívásával, hanem átfogó értékeléssel támasztotta alá a legszigorúbb szólásszabadság-mércék alkalmazását. A mérlegelés első lépéseként a testület a számunkra releváns kérdést járja körül, vagyis azt, hogy a vitatott közlés a közügyek szabad vitatásával áll-e összefüggésben. A határozat indokolása az Alaptörvényböl a strasbourgi esetekből ismerős összetett tesztet vezeti le: a kérdés megítéléséhez „elsődlegesen a közlés megjelenésének módját, körülményeit és a vélemény tárgyát, kontextusát szükséges figyelembe venni. Így a közlést érintően vizsgálni kell a médium típusát, a közlés apropóját adó eseményt, illetve az arra érkező reakciókat és az adott közlésnek ebben a folyamatban játszott szerepét. További szempontként szükséges értékelni a kijelentés tartalmát, stílusát, illetve a közlés aktualitását, valamint célját." ${ }^{68}$ Az indokolás következtetése szerint amennyiben e teszt alkalmazásával az állapítható meg, hogy a közlés a közügyek szabad vitatását érinti, úgy a közlés automatikusan a véleménynyilvánítási szabadság nyújtotta magasabb szintü oltalmat élvezi. Mindezek után a testület az elötte fekvő ügyet a legszigorúbb alkotmányjogi mércével vizsgálta, és a rágalmazás miatt büntetőjogi felelősséget megállapító ítéletet megsemmisítette.

Ezekre az ügyekre és értelmezésekre támaszkodva már kitűnően megfogalmazhatók azok a következtetések, amelyek a közügyek vitájának általános tesztje után kutatva számunkra most lényegesek. Egyfelől kulcsfontosságú fejlemény, hogy mára világossá vált, az Alkotmánybíróság doktrínája nem elégszik meg egy-egy körülményt kizárólagossá tevő tesztek alkalmazásával, hanem a demokratikus társadalmi vita fogalmát a maga összetettségében szemléli. A gyakorlat számára ezzel a legfontosabb

\footnotetext{
${ }^{67}$ Demuth kontra Svájc (38743/97), 2002. november 5-i ítélet, 41. bekezdések

68 13/2014. (IV. 18.) AB határozat, Indokolás [39]
} 
üzenet a helyén van: csakis átfogó, finomhangolt értékelés után hozható döntés arról, hogy a demokratikus nyilvánosságban megjelenő közlés nem része a közügyek megvitatásának. ${ }^{69}$

Másfelől ugyanakkor a tudományos elemzés további tanulságok levonására is vállalkozhat. Tiszteletben tartva, sőt erősen helyeselve a gyakorlat törekvését racionalizált (vagy legalább annak tűnő) tesztek kidolgozására, lássuk be, hogy jelen esetben ez a törekvés rendkívül korlátozott sikert eredményez. ${ }^{70} \mathrm{~A}$ véleménynyilvánítás „módja, körülményei, tárgya, kontextusa, tartalma, stílusa, aktualitása, célja" által meghatározott körön belül alighanem bármilyen, egy szólás értékelésekor esetleg releváns tényező megtalálhatja a maga helyét. Ha viszont ez így van, akkor a „teszt” alkalmazása önmagában nincsen segítségünkre a lényeges pontok - másképpen fogalmazva: a közérdeküség - azonosításában, hiszen nem rendelkezik szürő, relevanciát kijelölő erővel. Nem azt állítom, hogy ne lenne haszna egy ilyen formulának. Egyrészt fontos szolgálatot tesz azzal, hogy kifejezi az előttünk fekvő kérdés összetettségét, és így segít elkerülni a téves leegyszerüsítéseket, amelyek messze többször vannak a szólásszabadság kárára, mint hasznára. Másrészt éppen alkalmatlanságával mutat rá, illetve utal tovább arra, ami ennek a fejezetnek fő üzenete: a szólásszabadság doktrínájában a közügyek vitatásának kategóriáját mindenekelőtt nem tesztek, hanem a mérvadó alkotmányos érték helyes azonosításával és következetes szem előtt tartásával kell megragadnunk. ${ }^{71}$

\section{A közügyek vitájának alkotmányos koncepciója}

A gyakorlati tesztek körében végzett vizsgálódásunk arra vezetett, hogy távolról sem áll a rendelkezésünkre olyan teszt, amellyel egy szólás közvitához tartozásáról automatikus és biztos döntést tudnánk hozni. Formuláinknak a jogi gondolkodás, érvelés orientálásában és mederben tartásában lehet fontos szerepük, a végső válasz

\footnotetext{
${ }^{69}$ Ezzel nem azt állítom, hogy a gyakorlatban ne lennének a józan ész számára könnyü ügyek, azonban lássuk be, általában nem azok kerülnek a legfelső bírói fórumok elé.

${ }^{70}$ Lényegesen markánsabban fogalmaz Robert Post, aki a közérdeküség megragadására tett gyakorlati kísérlet „összeomlásának” tartja az amerikai Legfelső Bíróság hasonló következtetését, mely szerint a kérdést az ügy egésze alapján, a véleménynyilvánítás tartalmát, formáját és kontextusát is értékelve kell eldönteni. POST (12. 1j.) 679.

${ }^{71} \mathrm{Az}$ alkotmányos értékek és az alkotmánybíráskodás összefüggéseit elemző fontos mü a magyar irodalomban: ÁDÁM Antal: Alkotmányi értékek és alkotmánybíráskodás. Budapest, Osiris, 1998.
} 
megtalálásában ugyanakkor csak erősen korlátozott segítséget várhatunk tőlük. ${ }^{72}$ Félreértés ne essék: a joggyakorlat által kidolgozott szempontok fontosak és hasznosak - így például a közszereplői státusz különösen erős orientáló tényező -, de többre van szükségünk ahhoz, hogy a közlések rengetegében eligazodjunk. Igazi kapaszkodót csak az jelenthet a számunkra, ha következetesen szem elött tartjuk azokat az alkotmányossági szempontokat, amelyeknek a kérdéskörben releváns alkotmányos értékből fakadóan jellemezniük kell közügyeink demokratikus vitáját. Az alábbiakban e szempontok azonosítása után az Alkotmánybíróság gyakorlatából vett példákkal annak illusztrálására kerítek sort, hogy mindez, még ha elsőre elvont vizsgálódásnak is tünik, miként jut egészen konkrét gyakorlati jelentőséghez.

\subsection{A demokratikus közvélemény értéke}

Kiindulópontként érdemes felidéznünk azt a korábban tett megállapításunkat, hogy a szólásszabadság magyar doktrínájában a szólások alkotmányos alapértékét mindenekelőtt a nyilvános társadalmi párbeszédben való részvétel adja. Végső soron minden közlés, amelyet a véleménynyilvánítás hatálya alá sorolunk, relevanciával rendelkezik a demokratikus nyilvánosság számára: része a közösségi gondolatcserének. E tekintetben valamennyi szólás közös halmazt alkot, vagyis még a kereskedelmi kommunikáció megnyilvánulásai is ez alapján lehetnek fontosak a szólásszabadság-doktrína számára. A közügyek vitájának kategóriája ugyanakkor éppen azt fejezi ki, hogy a társadalmi párbeszédben megjelenő közlések alkotmányos jelentősége nem ugyanaz. Mindegyikük része a demokratikus nyilvánosságnak, de egyesek közülük oly módon részei annak, ahogy más közlések nem. A közvita lényegének megragadásához tehát egy olyan alkotmányos értékre van szükségünk, amely a társadalmi párbeszéden belül a diskurzus egy szükebb, a demokratikus berendezkedés számára megkülönböztetett módon fontos és ezért sajátos jellemzőkkel rendelkező tartományát jelöli ki. Azt gondolom, ezt az igényünket elégítheti ki az Alkotmánybíróság érvelésében következetesen központi szerephez jutó alkotmányos

\footnotetext{
${ }^{72}$ Hasonló következtetésre jut: R. George WRIGHT: Speech on Matters of Public Interest and Concern. 37 DePaul Law Review 27 1987-1988
} 
érték, a demokratikus közvélemény kategóriája. ${ }^{73}$ A gyakorlatban számtalanszor felbukkanó fogalmat most csupán a legalapvetőbb határozatok felidézésével állítom a középpontba. ${ }^{74}$

A 30/1992. (V. 26.) AB határozatnak a magyar doktrínát mindmáig megtermékenyítő alapvetése szerint a szólásszabadságot az teszi sajátosan értékes alapjoggá, hogy a demokratikus közvélemény kötetlen alakulása a fejlődni képes és eleven társadalom létezésének alapfeltétele. ${ }^{75}$ A gyalázkodás büntetőjogi tényállása a testület álláspontja szerint éppen azért volt alkotmányellenes, mert a közvéleményt demokratikus lényegétől fosztotta meg: ahelyett, hogy annak alakulását saját törvényeire, vélemények és reakciók folyamatos ütköztetésére bízta volna, büntetőjogi eszközökkel igyekezett rendet vágni. ${ }^{76}$

A 7/2014. (III. 7.) AB határozat az Alaptörvény rendelkezései alapján azonos következtetésre jutva szögezte le, hogy a szólásszabadság a demokratikus, plurális közvélemény fundamentuma. A korábbi alkotmányértelmezés megerősítése e tekintetben annál kevésbé lehetett meglepő, hogy az elmúlt években - a szólásszabadság szélesebb kontextusában - már maga az alkotmányszöveg is expressis verbis utalt a közvélemény demokratikus minőségének alkotmányos értékére és követelményére. Az alkotmánymódosító hatalom már a korábbi alkotmány hatálya alatt, 2010. július 7-i hatállyal új rendelkezést iktatott be az Alkotmány 61. §-ába, mely szerint a demokratikus közvélemény kialakítása érdekében mindenkinek joga van a megfelelő tájékoztatáshoz a közügyek tekintetében. ${ }^{77}$ A 2012. január 1-jén hatályba lépő Alaptörvény pedig mind a sajtó, mind a választási kampányidőszakban történő politikai reklámozás kapcsán nevesíti a demokratikus közvélemény biztosításának alkotmányos parancsát. ${ }^{78}$ A 7/2014. (III. 7.) AB határozat abból a szempontból is lényeges most a számunkra, hogy indokolásában - ismét utalva az egyéni önkifejezés szabadságára is - a közügyekkel összefüggő véleménynyilvánítás értékét abban

\footnotetext{
${ }^{73}$ A hazai irodalomban Smuk Péter is onnan közelít, hogy a kommunikációs alapjogok feladata a demokratikus közvélemény alkotmányos garanciáinak megteremtése. SMUK Péter: A demokratikus politikai diskurzus alkotmányos garanciái - délkelet-és kelet-európai kihivások. In: KOLTAY András TÖRÖK Bernát (szerk.): Sajtószabadság és médiajog a 21. század elején 2. Budapest, Wolters Kluwer, 2015. 140.

${ }^{74}$ A közvélemény fogalmával kapcsolatos bármilyen vizsgálódás alapvető forrása Jürgen Habermas szociológiai tisztázása. Jürgen HABERMAS: A társadalmi nyilvánosság szerkezetváltozása. Budapest, Osiris, 1999

${ }^{75}$ 30/1992. (V. 26.) AB határozat, Indokolás III.2.1., ABH 1992, 167, 171.

${ }^{76}$ Uo., Indokolás V.3., ABH 1992, 179-180.

${ }_{78}^{77}$ Alkotmány 61. § (3) bek.

${ }^{78}$ Alaptörvény IX. cikk (2) és (3) bek.
} 
ragadja meg, hogy a demokratikus közvélemény és akaratképzés számára a sokszínű társadalmi és politikai nézetek szabad kifejezése minősül a legmeghatározóbb követelménynek. A demokratikus közvélemény azt kívánja meg, hogy a társadalom valamennyi polgára szabadon fejthesse ki gondolatait, és ezzel a közvélemény alakítójává válhasson. ${ }^{79}$

A demokratikus közvélemény alkotmányos kategóriájának meghatározó sajátossága, hogy a magyar doktrína a sajtószabadság egyedi értékét hozzá elválaszthatatlanul kötődve ragadja meg. A kilencvenes évek alaphatározata, a 37/1992. (VI. 10.) AB határozat szerint a véleménynyilvánítási szabadság a sajtószabadság vonatkozásában sajátosan érvényesül, a sajtó szabadságát arra figyelemmel kell garantálnia az államnak, hogy a sajtó a véleményalkotáshoz szükséges információszerzésnek, a véleménynyilvánításnak és véleményformálásnak kitüntetett fontosságú eszköze. A sajtó tehát nemcsak a szabad véleménynyilvánítás eszköze, hanem a tájékoztatásé is, azaz alapvető szerepe van a véleményalkotás feltételét képező tájékozódásban. ${ }^{80} \mathrm{Az}$ előző alkotmány hatálya alatt született utolsó média-határozat, a 165/2011. (XII. 20.) AB határozat érvei értelemszerüen szintén támaszkodtak a sajtó sajátos alkotmányos szerepére és értékére. Eszerint a sajtó a demokratikus közvélemény megteremtését és fenntartását szolgálja, ellenőrzi a közélet szereplöinek, intézményeinek tevékenységét, a döntéshozatal folyamatát, tájékoztatja arról a politikai közösséget, a demokratikus nyilvánosságot. A sajtószabadság speciális védelmének és felelősségének alapvető indoka az egyéni véleményalkotáshoz elengedhetetlen közlések, a közérdekü információk teljességének nyilvánosságra kerülése. ${ }^{81}$ Mindenekelőtt ismét a 7/2014. (III. 7.) AB határozatra hivatkozhatunk annak szemléltetésére, hogy az Alkotmánybíróság a sajtó jelentőségét és szerepét az Alaptörvény hatálybalépését követően is a korábbiakkal egyező érték felhívásával azonosította. Ahogy arra az imént már utaltunk, az alapjoghoz kötődő központi érték megragadását ez esetben már maga az alkotmányszöveg is meghatározta, amennyiben az Alaptörvény IX. cikkének (2) bekezdése a sajtószabadság elismeréséröl és a demokratikus közvélemény kialakulásához szükséges szabad tájékoztatás feltételeinek biztosításáról együtt rendelkezik. Mindezek alapján a határozat kiemeli, hogy a sajtószabadság a szólásszabadság intézménye, a sajtó ugyanis - tevékenységének

\footnotetext{
79 7/2014. (III. 7.) AB határozat, Indokolás [39] és [45]

${ }^{80}$ 37/1992. (VI. 10.) AB határozat, Indokolás II.2.b), ABH 1992, 227, 229.

${ }^{81}$ 165/2011. (XII. 20.) AB határozat, Indokolás IV.1.1., ABH 2011, 478, 502-503.
} 
egyre összetettebb és szerteágazóbb jellege mellett is - mindenekelött a véleménynyilvánításnak, a véleményformálásnak és a véleményalkotáshoz nélkülözhetetlen információszerzésnek az eszköze. ${ }^{82}$ A $13 / 2014$. (IV. 18.) $A B$ határozat szintén a demokratikus közvélemény fundamentumaként utal arra, hogy a polgárok a sajtó révén juthatnak hozzá a véleményalkotáshoz nélkülözhetetlen információkhoz. ${ }^{83}$ Fontos szempontokat illeszt az érvelésbe a rendörök képmásának közölhetősége mellett döntő 28/2014. (IX. 29.) AB határozat is. Az indokolásban az Alkotmánybíróság rámutatott arra, hogy mind a korábbi alkotmány, mind az Alaptörvény egyértelmüen a demokratikus közvélemény kialakulásához kapcsolja a sajtó szabadságát és sokszínűségét, amit az is tovább erősít, hogy történeti alkotmányunk vívmányainak tiszteletben tartása szintén a sajtó szabadságának és a demokratikus közvélemény kialakításában betöltött szerepének kiemelt védelmét indokolja. ${ }^{84}$ A sajtószabadság önálló mögöttes értéke tehát kifejezetten a demokratikus közvélemény kialakulásához kötődik: a hazai alkotmányos koncepcióban a sajtószabadságot azért részesítjük speciális védelemben, hogy a demokratikus tájékozódáshoz szükséges információk áramlása minél kötetlenebb legyen, a média a tájékoztató tevékenységét minél szabadabban végezhesse. ${ }^{85}$ Végül érdemes idézni a 34/2017. (XII. 11.) AB határozatot, amely kifejezetten hangsúlyozza, hogy ,a sajtó nem egy a szólásszabadság jogosultjai közül, hanem olyan szereplö, aminek müködése különös alkotmányossági jelentőséggel bír”. ${ }^{86}$ A média ugyanis „a modernkori nyilvánosság fó letéteményese, nélküle teljes mértékben elképzelhetetlen a demokratikus társadalmi tanácskozás müködése". ${ }^{87}$

Meggyőződésem, hogy a - hasznos és szükséges, de választ önmagukban nem nyújtó - gyakorlati tesztekbe való görcsös kapaszkodás helyett egyedül a demokratikus közvélemény értékének szem elött tartása lehet segítségünkre a közügyek vitájához tartozó közlések felismerésében. Amelyik közlés közvetlen kapcsolatban áll a demokratikus közvélemény alkotmányos értékével, azaz közvetlen hatással van a demokratikus közvélemény alakulására, minőségére, az a szólásszabadság szigorúbb

\footnotetext{
${ }^{82}$ 7/2014. (III. 7.) AB határozat, Indokolás [40]

${ }^{83}$ 13/2014. (IV. 18.) AB határozat, Indokolás [25]

${ }_{85}^{84}$ 28/2014. (XI. 29.) AB határozat, Indokolás [11]-[14]

${ }^{85}$ E helyütt csak röviden utalok rá, hogy ez nem magától értődő. Vö. Vincent BLASI: The Checking Value in First Amendment Theory. American Bar Foundation Research Journal Vol. 2, 1977/3. A mögöttes érték pontos megragadásában rejlö eltérésekböl fontos hangsúlybeli különbségek adódhatnak. ${ }^{86} 34 / 2017$. (XII. 11.) AB határozat, Indokolás [20]

${ }^{87}$ 34/2017. (XII. 11.) AB határozat, Indokolás [41]
} 
védelmét élvezi. Amelyik közlés azonban csak közvetve, a nyilvános társadalmi kommunikációban történt megjelenése révén kapcsolódik hozzá, az nem támaszkodhat a véleményszabadság legerősebb érveire.

Kínálja magát a kérdés ezek után: mi az a „demokratikus közvélemény”, amelyhez kapcsolódnia kell a közvita körébe tartozó szólásnak. Azok számára, akik az eddigi fejtegetéseket követően továbbra is tartalmi, a közérdeküség valamifajta leírására épülő jogi definícióban reménykednek, kiábrándító lesz a válasz. Ez a fejezet ugyanis éppen arra a meggyőződésre épül, hogy abban a tartalmi értelemben, ahogy esetleg szeretnénk, a demokratikus közvélemény - és vele együtt a közügyek vitájának fogalma a jog számára megragadhatatlan. Nem tudunk általános normatív választ adni arra a kérdésre, hogy mi tartozik a demokratikus közvéleményhez, hiszen egy valóban pezsgő és vitázó, összetett és sokszínű társadalmi nyilvánosságban a közlések előre meghatározhatatlanul színes palettája hordozhatja magában annak lehetőségét, hogy a közös ügyeinkröl való gondolkodást aktívan és közvetlenül alakítsa. Annak az alkotmányos elvárásnak, hogy a demokratikus közvélemény saját törvényei szerint alakulhasson, első lényegi eleme éppen az, hogy alapvetően nem normatív definíciók vagy hatósági tekintélyek döntenek egy közlés közérdeküségéről. ${ }^{88}$ Maga a diskurzus az, amelyben egy szólás a párbeszédet folytatók szemében vagy rendelkezik ezzel az erővel, vagy nem. A közügyek vitájához tartozásról sokkal inkább a beszéd konkrét társadalmi körülményei döntenek, semmint elöre rögzített jogi előírások. A jogi döntéshozónak is ezért kell a közlések összetett kontextusára vetnie a szemét, nem pedig egyedi jellemzőket kiragadó tesztektől várnia a megoldást.

A demokratikus közvélemény alkotmányos értékként való szem előtt tartása abban segíthet minket, hogy a tényállás összes elemét értékelve, de bennük nem elveszve hozzuk meg jogászi döntésünket. Ha a körülmények tengeréböl ily módon sikerül kidugnunk a fejünket, akkor a demokratikus közvélemény értéke tartalmi definíció nélkül is orientálja a döntésünket: azokat az alkotmányossági szempontokat helyezi a mérlegelés középpontjába, amelyeknek döntéseink eredményeképpen jellemezniük kell a közügyek demokratikus vitáját. A korábbiakban már idézett határozatok és érvek mentén ezeket az irányadó szempontokat - kimerítő erőt legkevésbé sem vindikálva nekik - az alábbiakban ragadhatjuk meg.

\footnotetext{
${ }^{88} \operatorname{POST}(12.1 \mathrm{j}) 670-672$.
} 
Egyrészt a demokratikus közvélemény kategóriája a társadalmi, közéleti megszólalások olyan halmazára vonatkozik, amely tágabb a politikai diskurzusnál, de szükebb a nyilvános társadalmi párbeszéd körénél. Elöbbi általában a közhatalom gyakorlására és a politikus közszereplők tevékenységére fókuszáló fogalom, amelynél - mint láttuk - a demokratikus közvéleményt formáló közlések csoportja mindenképpen színesebb. Utóbbi pedig a magyar doktrínában a szólásszabadság hatályát kijelölő - így többek között a gazdasági reklámokat is felölelő - terminus, amelyhez képest a szigorúbb védelem alá eső véleménynyilvánítások körének szükségképpen szükebbnek kell lennie. Az előző fejezetben láttuk, hogy a hazai alkotmányos koncepció valamennyi közlést relevánsnak tartja, amely a társadalmi nyilvánosságba lépve a közösségi gondolatcsere részévé válik. A nyilvánosságnak szánt sokszínü üzenetekként még a reklámok is ezért jönnek számításba a szólásszabadság szempontjából, akkor is, ha diszkurzív jellegük adott esetben rendkívül csekély vagy hiányzik. ${ }^{89}$ Végső soron a társadalmi párbeszédbe került közlések mindegyike valamilyen fokú hatással lehet és van a demokratikus közvélemény alakulására, de ennél mindenképpen közvetlenebb kapcsolatot kell elvárnunk ahhoz, hogy értelmet nyerjen a védelem szükebb körének határvonala. Fontos elhatárolási szempontként adódik például, hogy a közügyekhez tartozás megállapításához nem elegendő önmagában az, ha egy közlésnek a közízlést vagy a közerkölcsöt formáló erőt tulajdoníthatunk. Az ilyen szólások közül sok természetesen része a közvitának, de azért, mert a társadalmi diskurzushoz kötődésük megragadhatóbb, konkrétabb, mint a más kifejezésekhez is kötődő áttételes hatás. A magánszférát védő hangsúlyos jogi szempontok határolják le továbbá halmazunkat abban a tekintetben, hogy a közszereplők magánélete főszabály szerint akkor sem része a közvitának, ha egyesek abból közvetett módon mindig képesek közéleti információt nyerni maguk számára. A politikusok magánélete csak jól megragadható, közvetlen indokkal tehető a nyilvános párbeszéd részévé.

Másrészt a demokratikus közvélemény a polgárok részvételét, közügyekbe kapcsolódását támogató, sőt sürgető alkotmányos érték. Az Alkotmánybíróság idézett döntéseinek láncolatából kibontakozó koncepció szerint a közvélemény demokratizmusa eleven, vélemények és ellenvélemények élénk vitájából saját

\footnotetext{
${ }^{89}$ Ez elvileg a reklámok „önálló” szólásszabadság-értékét jelenti, arról nem is beszélve, hogy a kereskedelmi szólások korlátozása nem elhanyagolható számú esetben politikai közlések visszaszorításának is eszköze.
} 
törvényei szerint alakuló diskurzust takar. A demokratikus közvélemény számára nem félelemre vagy bizalmatlanságra okot adó körülmény, ha minél több résztvevő kapcsolódik a vitába, hanem a demokrácia természetes és éltető velejárója. Annak kétségkívül meglévő társadalmi kockázatára, hogy a közvéleménynek bárki, még az elvagy megvetendő gondolat képviselője is alakítójává válhat, a demokratikus közvélemény alapvetően nem a feszültségek szőnyeg alá söprésével vagy a politikai korrektség követelményeinek jogi kikényszerítésével, hanem az alkotmányosság erőinek fellépésével felel.

Ezzel szoros összhangban emelhetjük ki harmadrészt, hogy a demokratikus közvélemény égisze alatt a diskurzus érintettjeit, megszólalókat és megszólítottakat egyaránt, mindenekelőtt autonóm és felelős polgároknak tekintjük, akik aztán közösen viselik a véleménycsere eredményét. ${ }^{90} \mathrm{~A}$ demokratikus közvélemény az önmagát demokratikusan kormányzó közösség tagjainak az önkormányzás mikéntjéről folytatott párbeszéde. Talán tanulságos lehet az analógia: bármit is gondoljunk arról, hogy polgártársaink miféle szempontok és motivációk szerint adják le voksaikat az önkormányzás nagy össznépi aktusa, a választások alkalmával, szavazatukra az alkotmányjog világában a felelős állampolgári cselekvés megnyilvánulásaként tekintünk. Nem nagyon lehet ez másképp a demokratikus közvélemény alakításával kapcsolatban sem, mivel azzal a demokratikus berendezkedés előfeltevéseit vonnánk kétségbe. Mindebből a közvélemény alakulását egy elképzelt helyes irányba terelő, a befogadókat paternalista módon óvó beavatkozás elutasítása következik. Fontos következtetés az is, hogy a demokratikus közvélemény követelményeinek ereje együtt fogy a diskurzust folytatók autonómiájának - egyedi körülmény alapján, szituációhoz kötötten megállapítható - csökkenésével. ${ }^{91}$

Negyedrészt a demokratikus közvélemény alakulásának kitüntetett fontosságú csatornája a sajtó. ${ }^{92}$ Tartalmi definíció híján a mérlegelés törvényszerüen talál kapaszkodót a társadalmi kommunikációnak a közvéleményt hagyományosan és

\footnotetext{
${ }^{90} \operatorname{PosT}(13.1 \mathrm{j}),. 483-485$.

${ }^{91}$ A hangsúly a szituációs kötöttségen van. Tézisünket az önmagában nem ássa alá, ha a benne foglalt emberkép adott esetben feszültségbe kerülhet a magunk körül érzékelt valósággal. Vö. pl. LENKOVICS Barnabás: Ptk. és Alkotmány, ember- és társadalomkép. Alkotmánybírósági Szemle 2011/2. 62.

${ }^{92}$ Smuk Péter is bár a demokratikus politikai diskurzus középpontjában álló „,közvéleményt” nehezen definiálható fogalomnak tartja, azt megfogalmazza, hogy ,[a] modern, általánosan felfogott közvélemény a sajtó és média tevékenységében nyilvánul meg." SMUK Péter: A demokratikus politikai diskurzus alkotmányos garanciái és gyakorlata Közép-Kelet-Európában. In: KOLTAY András - TÖRÖK Bernát (szerk.): Sajtószabadság és médiajog a 21. század elején. Budapest, Wolters Kluwer, 2014. 598.
} 
üzemszerüen befolyásoló csatornáiban. Egyéb csatornák mellett jelentőségére tekintettel kiemelkedik a média. A szabad sajtó a demokratikus közvélemény fundamentuma. Ezzel nem állítjuk sem azt, hogy a média a közvélemény formálásának vagy tematizálásának egyedüli letéteményese lenne, sem pedig azt, hogy minden, ami a sajtó hasábjaira kerül, automatikusan a közügyek vitájához tartozna. Az viszont a döntések számbavételét követően nyugodt szívvel állítható, hogy a vitatottá váló esetekben a vélelem amellett szól, hogy a sajtó tájékoztató tevékenysége - a maga hibáival együtt - a demokratikus közvélemény elemi érdekében áll. A vélelem megdönthetö, de megdöntése a szokásosnál is óvatosabb körültekintést igényel, és nem alapulhat egy-egy szempont kiragadásán.

Ötödrészt a demokratikus közvélemény fogalmának negatív ismertetőjegye, hogy nem tartalmi jellemzőket takar. Az Alkotmánybíróság következetesen hangsúlyozott értelmezése a tájékoztatás szabad áramlásáról, illetve a saját törvényei szerint alakuló közvéleményröl teljesen világossá teszi ezt. Ennek jelentősége a szólásszabadság általános korlátozásakor is jelentkezik, de kiváltképp hangsúlyozni kell a médiaszabályozás mércéinek kialakításával kapcsolatban. Igaz, hogy a demokratikus közvélemény értéke különösen a média esetében alkotmányos indokul szolgálhat speciális kötöttségek előírására, de olyan állami beavatkozásokat alapoz meg, amelyek a szabad nyilvánosságnak a kereteit, szerkezetét teremtik meg, nem pedig a tartalmát korlátozzák. ${ }^{93}$ A közlések tartalmára vonatkozó korlátozásoknak más jogalapot kell találniuk. Mi a jelentősége ennek az elhatárolásnak? Egyrészt a demokratikus közvélemény értéke a szólásszabadság doktrína megkérdőjelezhetetlen kulcsfogalma, amely alapján egyértelmű teendője lehet az államnak - fontos tehát, hogy ezt a lehetőséget jól értsük. Másrészt ha a demokratikus közvélemény fogalmát tartalmilag értenénk, és az alkotmányos értékekkel harmonizáló nézetek körére vonatkoztatnánk, akkor ezzel igen csak szélesre nyitnánk a korlátozás lehetőségét.

Meggyőződésem szerint ezek azok az elemek, amelyek - nem kimerítő jelleggel - a demokratikus közvélemény alkotmányos értékének sarokpontjaiként kibonthatók az Alkotmánybíróság judikatúrájából. Ezeknek az azonosítása azért bír jelentőséggel,

\footnotetext{
${ }^{93}$ Ez azokra a szabályokra is igaz, amelyek egyébként médiajogi értelemben a tartalomszabályozás körébe sorolhatók, mivel a szerkesztési szabadságot érintik, mint például a kiegyensúlyozott tájékoztatás követelménye vagy a politikai reklámok és hirdetések szabályozása. A demokratikus közvélemény működésének kereteit meghatározó tipikus szabályok közé tartoznak egyébként (a teljesség igénye nélkül): tulajdonosi korlátozások; a frekvenciapályáztatás szabályai; mindezen szabályok felügyeletére hatósági eljárások intézményesítése, egyáltalán: hatósági jelenlét a média világában; a közmédia pluralitást biztosító szervezetrendszerére vonatkozó követelmények.
} 
mert a közérdekűség vagy a közvélemény-formáló erő normatív, tartalmi definíciója híján a „közügyek vitája” kategóriájának szerepe a doktrínában leginkább az, hogy hangsúlyozza: lennie kell egy társadalmi kommunikációs térnek, amelyet ezek szerint az alapszempontok szerint rendezünk be, máskülönben sérülnek a kormányzás demokratikus alapjai. A közvélemény mint a társadalmi élet és a politikai cselekvés kommunikációs alapja és kerete ilyen feltételek között tud demokratikusan, mindenki részvételével formálódni.

Az alábbiakban annak járok még utána a joggyakorlat példáin keresztül, hogy ezek az irányadó szempontok nem csupán elvont elméleti jelentőséggel bírnak, hanem következetes szem előtt tartásuk a közügyek vitájának kérdéskörét érintő konkrét esetek kezelésénél is nagy szolgálatot tehetnek számunkra.

\subsection{A releváns érték helyes azonosítása a gyakorlat példáin}

Miután a közügyek vitájához kötődés meghatározásának elméleti kereteit a lehetséges mértékig felrajzoltuk, érdemes a gyakorlat példáin keresztül éreztetnünk, miként válhat perdöntővé a jogi értékelés során, hogy a tényállás vagy a vizsgálódás egyes tényezőihez kötjük-e magunkat, avagy a demokratikus közvélemény értékének

védelme lebeg-e a szemünk előtt. Értelemszerűen az eddig felhozott strasbourgi és hazai esetek mindegyike értékes szempontokkal szolgál, de itt most csak az elmúlt évek alkotmánybírósági gyakorlatának arra a három ügyére mutatok rá, amelyek különösen is tanulságosnak tünnek.

A 23/2010. (III. 4.) AB határozatot több okból is érdemes kiemelnünk. Egyrészt, ahogy már említettük, ez a határozat hívta föl a figyelmet arra, hogy a föszabály szerint gyengébb alkotmányos védelemben részesülő kereskedelmi szólás összefonódhat a közügyek vitatásával, ezért korlátozásakor körültekintően kell eljárnia a jogalkotónak. Másrészt annál inkább indokolt visszatérnünk erre a döntésre, mivel az Alkotmánybíróság az elvi kijelentéseknek rögtön súlyt is adva kivételesen egy reklámokhoz kapcsolódó törvényi rendelkezés megsemmisítésére szánta el magát. A szóban forgó rendelkezés feljogosította az eljáró hatóságot, illetve a bíróságot, hogy megtiltsa a még közzé nem tett reklám közzétételét, ha megállapítja, hogy a reklám a gazdasági reklámtevékenységre vonatkozó elöírásba ütközne. Az Alkotmánybíróság 
abból indult ki, hogy az előzetes ellenőrzésnek ez a lehetősége - az általános fogalmazás következtében - a közlések rendkívül széles körét érintheti, különös tekintettel arra, hogy a sajtótermékben lévő reklámok közzétételének előzetes hatósági tiltása magának a sajtótermékeknek a megjelenését is akadályozhatja. Ez a „reklámszabály” tehát már nemcsak gazdasági érdekeket szolgáló, hanem kiemelt védelmet érdemlő kifejezéseket is érinthet, aminek következtében az Alkotmánybíróság aránytalan korlátozásnak ítélte. A határozat így annak a disztingvált megközelítésnek lett szép példája, hogy a kereskedelmi kommunikációnál, így a gazdasági reklámok esetében is mindig érzékenynek kell lennünk arra, hogy a szabályozás valóban csak a gazdasági érdekek kommunikálását korlátozza-e. Ha annál szélesebb körü korlátozással találjuk szemben magunkat, akkor a magasabb szintü védelmi mércék is működésbe léphetnek. A testület a konkrét esetben érzékeny maradt arra a körülményre, hogy a jogszerütlen reklámra tekintettel indokolt hatósági fellépés „szélessége” nem okoz-e kárt a demokratikus közvélemény alakulásában. Mivel egy sajtótermék megjelenésének előzetes tiltása már a demokratikus közvélemény értéke számára fontos közlések elvesztésével járhat, arra nem szolgáltathatott alkotmányos indokot a kereskedelmi szólásokkal szembeni jogos fellépés.

A közelmúlt egyik alkotmánybírósági ügye hasonló kérdéseket vethetett volna föl, de ez esetben a testület kevésbé vette figyelembe a demokratikus közvélemény értékének esetleges veszélyeztetettségét. A 3208/2013. (XI. 18.) AB határozatban más alaptörvényi hivatkozások elbírálása mellett - arról döntöttek az alkotmánybírák, hogy a közutak melletti reklámtáblák elhelyezésének rendjét a korábbiakhoz képest jelentős mértékben szigorító, számos új tilalmat bevezető szabályozás alkotmányellenesen korlátozza-e a szólásszabadságot. Az Alkotmánybíróság kifejezetten fenntartotta a korábbi gyakorlatban kidolgozott értelmezéseket, ${ }^{94}$ és a reklámozás lehetőségének szükítését a véleménynyilvánítás hatálya alatt vizsgálta. Úgy tünik azonban, hogy ez esetben a testület nem fordított kellő figyelmet a demokratikus közvélemény értékének irányába mutató körülményekre. A határozat a gazdasági reklámok alacsonyabb védettségének tesztjét alkalmazta, röviden hivatkozva arra, hogy az indítványozók nem hoztak fel olyan érvet, illetve az ügy egyéb körülményei sem utalnak arra, hogy a reklámelhelyezés vizsgált korlátozása olyan hirdetéseket érintene, melyek jelentős közérdekű kérdésekhez kapcsolódnak, vagy

\footnotetext{
${ }^{94}$ 3208/2013. (XI. 18.) AB határozat, Indokolás [104]
} 
hogy az érintett reklámtáblák esetében az üzleti érdekek összekapcsolódnának közügyek megvitatásával és a véleménypluralizmussal. Valójában azonban nagyon is felhozhatók azok az érvek, amelyek szerint „az ügy egyéb körülményei” szigorúbb szólásszabadság-vizsgálatot érdemeltek volna. Mindenekelőtt már a mindennapi gyakorlat is óvatosságra int, hiszen a köztéri reklámplakátok rendszeresen válnak politikai üzenetek hordozóivá, különösen választási időszakban, így a szabályozás egyértelmüen túlnyúlik a kereskedelmi kommunikáció körén. A releváns fogalommeghatározás pedig csak tovább növelhette volna a gyanakvást a korlátozással szemben, hiszen annak értelmében az új szabályozás kifejezetten vonatkozott azokra a hirdetésekre is, amelyek célja, hogy a közúton közlekedőket ideológiák, elvek, értékek, elképzelések támogatásáról vagy elutasításáról meggyőzze. ${ }^{95}$ Nehezen vitatható, hogy ez a fordulat már közvetlenül utal olyan közlésekre, amelyek szoros kapcsolatban állnak közügyek vitatásával, adott esetben jelentős közérdekü kérdésekkel. Nem véletlen, hogy amikor egy későbbi jogszabály-módosítás a definícióban már kifejezetten feltüntette a választási plakátokat, ${ }^{96}$ akkor voltak, akik a kormányzati lépést csupán olyan pontosításként értelmezték, amely érdemben nem vont be újabb kategóriát a korlátozás hatálya alá. ${ }^{97}$ Márpedig ha a korlátozás közéleti közléseket is érintett, akkor az a határozatban felhozott szempontokat lényegesen más megvilágításba helyezi. Mindezek alapján ez az ügy annak lehetett volna újabb példája, hogy a demokratikus közvélemény érintettségének szempontját szívén viselő vizsgálat nem állhat meg annál, hogy a korlátozás első ránézésre csupán kereskedelmi érdeket szolgáló közlésekre vonatkozik. E helyett azonban annak lett példája számunkra, hogy az egyes tényezőket kiragadó, jelen esetben kizárólag a kereskedelmi érdek megjelenésére fókuszáló mérlegelés miként tévesztheti szem elől a mögöttes értékek számára fontos további körülményeket.

Talán még az eddigieknél is izgalmasabb részletesen kibontanunk a bírósági döntést támadó alkotmányjogi panasz alapján született 3/2015. (II. 2.) AB határozat alkotmányos megfontolásait. Az Alkotmánybíróságnak sajtótermékre kivetett piacfelügyeleti bírsággal kapcsolatos ügyben kellett döntenie, miután a gazdaságipénzügyi kérdésekkel foglalkozó hírportál cikkét a hatóság a valós információk

\footnotetext{
${ }^{95}$ A reklámtáblák, reklámhordozók és egyéb reklám célú berendezések közutak melletti elhelyezésének részletes szabályairól szóló 224/2011. (X. 21.) Korm. rendelet 1. §-a.

96 5/2014. (I. 17.) Korm. rendelet 1. §-a.

97 http://mno.hu/belfold/lukra-futottak-a-jogvedok-a-valasztasi-plakatokkal-1207244; letöltés ideje: 2017. április 17.
} 
ellenére spekulatívnak minősítette, amely az érintett cég (MOL Zrt.) tőzsdei papírjaira nézve tiltott piacbefolyásolást valósított meg. Az alkotmánybírósági érvelés központi eleme szerint az ügy a szólás- és sajtószabadság fokozottan védett körébe, a közügyek megvitatásához tartozik, ezért az ítéletben foglaltaknál szigorúbb alkotmányossági vizsgálatnak és szorosabb törvényértelmezésnek van helye. Az ügy gazdasági érintettsége tehát ez esetben hangsúlyozottan nem járt azzal a következménnyel, hogy az Alkotmánybíróság a kereskedelmi szólásokra vonatkozó alacsonyabb korlátozási teszteket alkalmazta volna. A testületnek ez a döntése megragadhatóvá teszi, miként válik perdöntő gyakorlati jelentőségüvé a mögöttes alkotmányos értékek pontos azonosítása és figyelembevétele. Ennek megragadása azért hasznosnak tünik, mert a határozathoz füzött egyes különvélemények és elemzések éppen ezen a ponton vitatták a döntés helyességét. ${ }^{98}$

A szóban forgó tényállás gazdasági érintettsége nyilvánvaló. A nyilvánvalót az Alkotmánybíróság határozata sem tagadja: a testület kifejezetten elismerte, hogy a tökepiaci törvény vonatkozó rendelkezése, a piacbefolyásolás tilalma a vizsgált körülmények között relevanciával bír, adott esetben érvényesítésre tarthat igényt. A MOL-t ugyanis nemcsak az jellemzi, amit az Alkotmánybíróság e határozata közéleti jelentőségüként kiemel, ti. hogy a magyar gazdasági élet egyik legfajsúlyosabb, számottevő állami részesedéssel müködő társasága, hanem az is, hogy az energiapiaci verseny résztvevője, amelynek a részvényeivel a tőkepiacon szabadon kereskednek. Hogy mégse elégedjünk meg ezzel a körülménnyel, arra a besorolás általános nehézségein túl a tisztességes verseny védelmével összefüggő strasbourgi ügyek konkrétan is figyelmeztetnek. Láttuk, ${ }^{99}$ hogy az EJEB mind a Barthold kontra Németország, ${ }^{100}$ mind pedig a Stambuk kontra Németország ${ }^{101}$ ügyben annak ellenére döntött a szólásszabadság javára, hogy elismerte a vitatott megszólalások negatív hatását a tisztességes verseny szempontjából. A bíróság azonban további körülményeknek tulajdonított meghatározó jelentőséget, mindenekelött annak, hogy a szóban forgó közlések a sajtónak a közvéleményt tájékoztató tevékenysége körében merültek föl. A Markt Intern Verlag Gmbh és Klaus Beermann kontra Németország

\footnotetext{
${ }^{98}$ Lásd Balsai István és Szívós Mária alkotmánybírák különvéleményeit, illetve: HÖRCHERNÉ MAROSI Ildikó - KoRMÁNYOS Zoltán: Az Alkotmánybiróságnak a Fövárosi Közigazgatási és Munkaügyi Bíróság piacfelügyeleti bírsággal kapcsolatos ügyben hozott itéletét megsemmisitö döntése. Jogesetek Magyarázata 2015/3.

${ }^{99}$ Lásd a jelen fejezet 2.2. pontját.

${ }^{100}$ Barthold kontra Németország (8734/79), 1985. március 25-i ítélet.

101 Stambuk kontra Németország (37928/97), 2002. október 17-i ítélet.
} 
ügyben ${ }^{102}$ pedig az EJEB annak figyelembevételével jutott a kiadót (markt intern) sújtó elmarasztalás helybenhagyására, hogy bár a markt intern nem volt a sértett kozmetikai cég versenytársa, nyíltan vállalta, hogy tevékenységét a kiskereskedők érdekeinek szolgálatában és a nagyvállalati érdekek gyengítése céljából folytatja, aminek elsődleges terepe ráadásul kiadványainak érdekképviseleti jellegü szerkesztése és megjelentetése volt A markt intern-ítélet érvelése tehát a „kereskedelmi kontextus” megragadásához éppen annak megállapításán keresztül jutott el, hogy a vizsgált kiadvány a hagyományos tájékoztató szerepből kilépve vállaltan és tendenciózusan belépett az egymással versenyző gazdasági szereplők szférájába. Észre kell vennünk, hogy ezekben az ügyekben másról, többröl van szó annál az általános óvatosságnál, hogy még a gazdasági érdekekkel összefüggő megszólalások is a szólásszabadság védettebb körébe tartoznak, ha azok nem pusztán egyéni kereskedelmi közlések, hanem közérdeklődésre számot tartó diskurzus részét képezik. Az esetekből kiolvasható érvelés szerint az egymással versengő piaci szereplők megszólalásainak értékeléséhez képest megváltozik a képlet, ha a sajtó tájékoztató szerepe ,játékba jön”. Nem csodálkozhatunk ezen, hiszen ebben az esetben a kereskedelmi versenytársak vitájához képest gyökeresen megváltozik a felállás: olyan szereplő lép be a képbe, akinek a megjelenése önálló alkotmányos jelentőséggel bír. A sajtószabadság mögöttes értéke, vagyis a demokratikus nyilvánosság tájékoztatásának szempontja saját értékelést követel magának, ami adott esetben könnyen meg is változtathatja a játék kimenetelét. Ekkor ugyanis adott esetben olyan közlések sem veszítik el a kiemelt alapjogi védettséget, amelyek más körülmények között esetleg alacsonyabb védelmi teszttel lennének mérhetők. Döntő jelentőségű tehát, hogy a tényállás alapján helyesen azonosítsuk a releváns alkotmányos értékeket, és azokhoz igazodóan válasszuk meg a körülmények mérlegelésére hivatott tesztet.

A 3/2015. (II. 2.) AB határozat érvelésének a szólás- és sajtószabadságra vonatkozó része ugyanebbe az irányba vezet bennünket. A döntés szerint a szóban forgó cikk a szólásszabadság fokozottan védett körébe tartozik, mivel a közügyekről folytatott diskurzus részét képezi. Az indokolás ennek alátámasztására elöször - igaz, lakonikusan - kiemeli azokat a legfontosabb tartalmi elemeket, amelyek alapján a hírportálon megjelent cikk közvetlen összefüggésben áll a közügyek vitájával. Eszerint a MOL a magyar gazdaság és tőkepiac egyik legjelentősebb társasága, amely

\footnotetext{
${ }^{102}$ Markt Intern Verlag Gmbh és Klaus Beermann kontra Németország (10572/83), 1989. november 20-i ítélet
} 
számottevő állami részesedéssel müködik, és a cég horvátországi tulajdonszerzésével kapcsolatos korrupciós gyanú, az ezzel összefüggő eljárások, továbbá ezeknek a történéseknek a tulajdonosi körre, illetve a részvények árfolyamára gyakorolt esetleges hatása közügynek minősülnek. Kétségtelen, hogy az indokolás ezen túl nem hatol semmilyen konkrét teszt mélyére, de mint láttuk, ebben a körben nem is ez a müvelet az, ami a dolgokat alkotmányos helyükre teszi. Az Alkotmánybíróság e helyett nagy hangsúlyt fektetett az ügyben releváns alkotmányos értékek kidomborítására: a határozat érvelése a sajtószabadság egyedi alkotmányos jelentőségét tartotta perdöntőnek, és annak figyelembevételével választotta meg a mérlegelés tesztjét. Ez vezetett arra, hogy a testület olyan iránymutatást adott a tőkepiaci törvény értelmezésére, amely nem áll meg a gazdasági érdekek számításba vételénél, hanem mindenekelőtt a sajtó tájékoztató szerepe felől közelíti meg a felmerülő kérdéseket. A sajtószabadság egyedi alkotmányos értékére, a sajtónak a demokratikus közvélemény alakulásában betöltött alkotmányos szerepére tekintettel az a körülmény, hogy a hírportál közérdeklődésre számot tartó közügyben közölt információkat, elegendő volt ahhoz, hogy az Alkotmánybíróság a közvita védelmének szigorával lépjen fel. ${ }^{103} \mathrm{~A}$ sajtó közügyekben folytatott tájékoztató tevékenysége tehát a szólásszabadság fokozottan védett körébe tartozik - akkor is, ha a közügy gazdasági érdeket érint. Az már egy következő kérdés, hogy maga a közéleti szólásszabadság sem teljesen homogén közeg, mivel a versengő alkotmányos értékek köre szituációtól függően bizonyos mértékig változhat. ${ }^{104}$ Ám ahogy arra korábban utaltunk, a szólásszabadságot más értékekkel ütköztető konkrét mércék müködésének kérdése már önálló elemzést igényel.

A fejezet végén rövid összefoglalással élve: a fentiekben annak jártunk utána, mi a szerepe és miként ragadható meg a közügyek vitájának nagy jelentőségű kategóriája a szólásszabadság elmélete és gyakorlata alapján. Vizsgálódásunk érdekes paradoxont tárt fel: noha a véleménynyilvánítás doktrínájának központi tétele, hogy a közlések alkotmányos védettsége közügyekhez kötődésük függvényében alakul, ugyanez a

\footnotetext{
${ }^{103}$ A határozat érvelésének részletesebb elemzésére lásd: TÖRÖK Bernát: Alkotmányjogi tesztek hálójában. A sajtószabadság esete a tőkepiaccal. In: FeJES Zsuzsanna - TÖRÖK Bernát (szerk.): „SUUM CUIQUE - Ünnepi tanulmányok Paczolay Péter 60. születésnapja tiszteletére”. Szeged, Pólay Elemér Alapítvány, 2016.

${ }^{104}$ Az Alkotmánybíróság ennek megfelelően a jelen esetben is elismerte a szóba jövő versengő érték relevanciáját, amikor a tőkepiacok külső befolyástól mentes zavartalan működését az Alaptörvény alapján olyan legitim szabályozási célnak tekintette, amely a sajtó tájékoztató tevékenységének is korlátja lehet.
} 
doktrína nem tud számunkra biztos kézzel alkalmazható tesztet nyújtani e kötődés megállapítására. Ha csupán az előttünk fekvő ügy részleteibe zárva, egyedi formulákba merülve keressük a kivezető utat, jó eséllyel nem fogjuk megtalálni. A helyes mérce kiválasztása ugyanis nem következik automatikusan a tényállásból, hanem ahhoz az alapvető kérdéshez vezet, hogy a tényállás milyen alkotmányjogilag releváns érték(ek)re mutat tovább. A közügyek vitája kapcsán a gyakorlat hasznos szempontokra irányítja ugyan rá a figyelmünket, de a dolgok csakis akkor kerülhetnek a helyükre, ha mérlegelésünket a demokratikus közvélemény alkotmányos értékének érvényesülése vezérli. E paradoxon nyomon követése után azoknak az alkotmányossági szempontoknak a megragadására törekedtem, amelyek a demokratikus közvélemény fogalmából eredve a közügyek körének helyes megrajzolásában segítenek. Ezzel a szemléletváltással továbbra sem nyerünk tartalmi definíciót a közvita meghatározására (egy ilyen definíciós kísérlet a kérdés kontextualitása miatt szükségszerüen kudarcra van ítélve), viszont sokkal jobban láthatóvá válik, mi a mérlegelés valódi tétje: érzékenyek maradunk-e a saját szempontjai szerint alakuló demokratikus közvélemény alkotmányos programjának sikerére. Merthogy „a demokrácia egész építménye végső soron a közvéleményre támaszkodik."105

${ }^{105}$ Giovanni SARTORI: Demokrácia. Budapest, Osiris, 1999. 51. 


\section{Következtetések}

1. A véleményszabadság hatálya alá tartozó közlések nem ugyanazzal az erővel jönnek számításba, mivel nem azonos módon állnak kapcsolatban az igazolás alapvető értékével, a demokratikus részvétellel: a közügyek vitája a szólásszabadság legbelső védelmi köréhez tartozik.

2. Az alkotmányos védelem szempontjából alapvető jelentőséggel bír, hogy a társadalmi párbeszédbe belépő közlések közül melyeket soroljuk a közvita körébe. Törekvésünket, hogy gyakorlati jogi tesztjeinkkel világos és egyértelműen alkalmazható határokat húzzunk meg, összességében mégsem koronázhatja siker.

3. A megszólalással érintett személy státusza korántsem ad a kezünkbe mindent elrendező tesztet a közügyek vitájának meghatározásakor: bár meghatározó szempontja marad az alkotmányos vizsgálatnak, de nem építhetünk csak rá. A fokozott védelemre irányadó szempontok egyfelöl tágabb körben irányadók, mint a közhatalom gyakorlóit vagy a hivatásszerüen közszereplést vállalókat érintő bírálatok köre, másfelől azonban nem vonatkoznak a közéleti szereplőket illető, de közügyekkel kapcsolatban nem álló véleményekre.

4. Bár a gyakorlat világos tétele a kereskedelmi szólások kevésbé szigorú védelme a szólásszabadság alapján, a gazdasági érdek, érintettség vagy kihatás sem ad a kezünkbe egyértelmü tesztet a közügyek vitájának meghatározásakor. A kereskedelmi érdeket is érintő kommunikáció összefonódhat a közügyek vitájával.

5. A müvészeti alkotások, bármilyen fontosak is legyenek a társadalmi párbeszédben, önmagukban még nem tartoznak a közvita dogmatikai körébe. A közlés művészi jellege a szólásszabadság felőli értékelés fontos szempontja marad, de a közügyek vitájának meghatározásához önmagában nem visz közelebb.

6. A szólással érintett kérdés közérdeküségére fókuszáló általános teszttel sem tudunk biztosabb eredményre jutni: az ilyen teszt - helyesen - az ügy valamennyi körülményének összetett mérlegelésére szólít fel, ezzel azonban el is veszíti a releváns tényezőket valóban kijelölő szerepét.

7. A jogi tesztek rendeltetése tehát ebben a körben korlátozott: bár sok esetben nagy hasznunkra vannak a mérlegelés során, összességében nem várhatjuk tőlük a releváns körülmények biztos beazonosítását. Összetettségük ugyanakkor a lényegre tereli 
figyelmünket: döntésünk társadalmi kontextusára és a célul tüzött alkotmányos érték szolgálatára.

8. A közügyek vitájának helyes felfogásában a demokratikus részvételt szolgáló demokratikus közvélemény alkotmányos értékének szem előtt tartása lehet segítségünkre: belőle vezethetők le azok az alkotmányossági szempontok, amelyeknek döntéseink eredményeképpen jellemezniük kell a közügyek demokratikus vitáját.

9. A demokratikus közvélemény irányadó jellemzői:

9.1. saját törvényei szerint alakul: a közügyek vitájához tartozásról sokkal inkább a beszéd konkrét társadalmi körülményei döntenek, semmint elöre rögzített jogi elöírások

9.2. tágabb a politikai diskurzusnál, de szükebb a nyilvános társadalmi párbeszéd körénél

9.3. a demokratikus közvélemény a polgárok részvételét, közügyekbe kapcsolódását támogató, sőt sürgető alkotmányos érték

9.4. a demokratikus közvélemény égisze alatt a diskurzus érintettjeit autonóm és felelős polgároknak tekintjük, akik aztán közösen viselik a véleménycsere eredményét

9.5. a demokratikus közvélemény alakulásának kitüntetett fontosságú csatornája a sajtó: tartalmi definíció híján mérlegelésünk törvényszerüen talál kapaszkodót a közvélemény-formálás hagyományos és üzemszerü csatornáiban

9.6. a demokratikus közvélemény fogalmának negatív ismertetőjegye, hogy nem tartalmi jellemzőket takar: önmagában véve olyan állami beavatkozásokat alapoz csak meg, amelyek a szabad nyilvánosság kereteit, szerkezetét teremtik meg

10. A közügyek vitájának szerepe az, hogy hangsúlyozza: lennie kell egy társadalmi kommunikációs térnek, amelyet ezek szerint az alapszempontok szerint rendezünk be, máskülönben sérülnek a kormányzás demokratikus alapjai. 


\section{A SZÓLÁSSAL OKOZOTT ÁRTALMAK}

A szólásszabadság nem korlátozhatatlan. Bár a szélesebb korlátozás hívei rendszeresen ezzel ellentétes álláspont erőltetésével vádolják a véleményszabadság kitüntetett szerepe mellett érvelöket, a közlések korlátozhatatlanságának gondolata valójában nem bír támogatottsággal. Egy ilyen álláspont felvállalása egyébként is csak elvont elméleti konstrukcióként lehetne érdekes, a körülöttünk lévő valóság magyarázatában és rendszerezésében semmit nem segítene nekünk: körbenézve a szólásszabadság számos korlátozását azonosíthatjuk magunk körül. A véleménynyilvánítás szabadságának kitüntetett helyét a magyar doktrínában megalapozó alkotmánybírósági határozat maga teszi világossá: ez az alkotmányos szerep nem vezet arra, hogy a jog - az élethez vagy az emberi méltósághoz való joghoz hasonlóan - korlátozhatatlan lenne. ${ }^{1}$ Nem ez tehát a kérdés, hanem az, hogy milyen szempontok szerint, milyen körülmények között tartjuk korlátozhatónak. E tekintetben már lényegesen eltérő álláspontokat találunk, és a diskurzust hallgatva az lehet az érzésünk néha, mintha ez a vita valójában konkrét támpontok nélkül, személyes intuíciók alapján folyhatna csak, és ne lennének - legalább valamilyen mértékig - megragadható kapaszkodóink. Ezzel szemben a valóság az, hogy ha elméleti szempontjaink tükrében tüzetesen megvizsgáljuk a szólásszabadság magyar gyakorlatát, akkor abból számos dogmatikai kapaszkodót nyerhetünk, amelyeknek meghatározó erővel kell orientálniuk döntéseinket.

A következő fejezetekben néhány olyan szempont azonosítására törekszem, amelyek átfogó jelleggel befolyásolják a szólásszabadság korlátozásáról való jogi gondolkodásunkat. Szükséges és hasznos, hogy az elméleti keretek felrajzolásakor némiképp elkülönítsük egymástól ezeket a mérlegelési csomópontokat, jóllehet a gyakorlati válaszkeresésben szétválaszthatatlanul összefonódnak egymással. Mint látni fogjuk, valójában azzal segítik a munkánkat, hogy több irányból közelítve, de egymáshoz szorosan kötődve (néhol akár átfedésekkel) teszik megragadhatóvá számunkra a mérlegelés során szemünk előtt tartandó tényezőket.

Az egyik ilyen kérdéskör, amely - néha kimondva, jobbára azonban kimondatlanul - a véleményszabadság egész doktrínájának meghatározó eleme, a szólásokkal

\footnotetext{
${ }^{1}$ 30/1992. (V. 26.) AB határozat, Indokolás V.1., ABH 1992, 167, 178.
} 
okozható bántalmak felől közelít. Az alábbiakban előbb a téma meghatározó elméleti kereteit rajzolom föl, majd e gondolatok fényében próbálom meg azonosítani a magyar gyakorlat válaszait.

\section{1. Ártalmasak-e a szólások?}

A szólásszabadság elméletét és gyakorlatát egyaránt áthatja az a gondolkodás, hogy sajátosnak tekinthetők-e, és ha igen, miért és mennyiben, kommunikatív aktusaink a bennük rejlő ártó képesség szempontjából. Megkülönböztető jegye-e a szólásoknak egyéb emberi cselekvésekhez képest, hogy különleges viszonyban állnak a másoknak okozható bántalmakkal? A szólásszabadság egyedisége és sajátos védelme ugyanis akár azzal is igazolható lenne, hogy e jog gyakorlásának korlátozására lényegesen kevesebb érvet tudunk felhozni másoknak okozott sérelmekre hivatkozva. Jelen vizsgálódásunk végeredményképpen azt a kérdést veti föl, hogy mit tekintsünk olyan sérelemnek, amelyre indokoltnak tünik jogi eszközökkel reagálni. Célunk ezúttal is az, hogy ráleljünk a magyar doktrína válaszaira, amihez most is nélkülözhetetlen kapaszkodót nyújtanak számunkra az elmélet szempontjai.

Azok, akik a szólásszabadság kitüntetett helyét a közlésekkel okozható ártalmak specialitása felől ragadnák meg, legalább két, egymástól eltérő álláspontra helyezkedhetnek: egyrészt mondhatják, hogy szavaink eleve nem képesek a fizikai sérelmekhez mérhető kárt tenni, másrészt érvelhetnek kifejezéseink sajátos hatásmechanizmusával. Mint legradikálisabb állásponttal, logikusnak tünik az előbbivel kezdeni, még ha annak gyakorlati hatása ma már csekélynek is tekinthető.

Az a nézet, hogy a megragadható, materiális következményekkel járó tettleges cselekedeteinkhez képest megszólalásaink nem képesek hasonlóan káros következmények kiváltására, korántsem tekinthető szélsőségesen elvont elméleti konstrukciónak. Jelentéktelensége mellett annál inkább nehéz lenne érvelni, mert feltételezett igazságát angolszász népi bölcsesség is őrzi: „Összetörhetsz kővel vagy bottal, de nem árthatsz nekem szóval."2 A gondolat különféle formában a szólásszabadságról folytatott diskurzusban is megjelenik. Egyrészt konkrét esetek,

\footnotetext{
${ }^{2}$ Egyik megfogalmazása szerint: „Sticks and stones may break my bones, but words can never hurt me.” Érdekes hangulati különbségek azonosíthatók ugyanakkor a mondóka különféle megjelenési formái között, amelyek fellelhetök a Wikipédia „Sticks and stones” szócikke alatt.
} 
vitatott kifejezések kapcsán mindig hallani elsőre meghökkentő, sokaknak fájó kijelentések valójában ártalmatlan voltáról, másrészt az irodalomban is találhatók érvelések, amelyek az ártalmatlanság (vagy legalábbis: kisebb ártalom) szempontját hangsúlyozva lényegében ezt az irányt követik. Van, aki a szólásszabadság kiemelkedő alkotmányos jelentősége melletti központi érvnek tartja, hogy annak gyakorlása egyéb cselekvésekhez képest kisebb eséllyel kerül összeütközésbe más szabadságokkal. ${ }^{3} \mathrm{Az}$ ezzel rokon érvelés szerint pedig a véleménynyilvánítások és a fizikai tettek közti választóvonal egyik döntő szempontja, hogy elöbbiek kevésbé alkalmasak közvetlen vagy azonnali sérelem okozására. ${ }^{4}$

Ezzel szemben mind az általános gyakorlat, mind a teoretikusok elsöprő többsége abból indul ki, hogy szavainkkal, ha akarunk, nemcsak bántani tudunk, hanem akár komoly sérelmet is tudunk okozni. Távolról sem állítom, hogy a szólásszabadság diskurzust ne hatná át a szólásokkal okozott ártalmak sajátosságának gondolata, sőt kifejezetten amellett fogok érvelni, hogy a véleménynyilvánítások káros következményeinek mérlegelésekor valóban különleges szempontokra kell figyelemmel lennünk. A véleményszabadság doktrínáját ugyanakkor nem építhetjük mint ahogy nem is építjük - a „kisebb ártalom elvére”. Jóllehet szavaink hatását sokszor nehéz megbecsülni, és nagyon könnyű túlbecsülni, mégis általánosnak mondható emberi tapasztalat, hogy azok képesek bántani és kárt okozni. Megesik, hogy éppen ezért mondjuk ki őket. Bár a szakirodalom jellemzően eleve adottnak veszi, hogy a szólásszabadság doktrínája nem épül(het) a szavak ártalmatlanságának vélelmére, akadnak szerzők, akik részletesebb elemzést szentelnek a kérdésnek. Érveik számbavétele azért is fontos, mert noha a kisebb ártalom kérdésének megítélésében nem tudjuk teljesen kiiktatni intuícióink szerepét, egy-egy tényező világos megragadása sokat tisztíthat gondolkodásunkon.

Több ilyen elemre irányítja rá a figyelmünket a kisebb ártalom elvének könyörtelen kritikusa, Frederick Schauer. A szólásokkal okozható sérelmek tipológiájának kifejtését későbbre hagyva itt most csak azt emelem ki, hogy Schauer mindegyik csoportban igazolhatatlannak látja szavaink ártalmatlanabb természetét. Szerinte amikor cselekedetünk valaki másnak a károkozását segíti elő, akkor a kisebb ártalom

\footnotetext{
${ }^{3}$ Michael D. BAYLES: Mid-Level Principles and Justification. In: J. Roland Pennock and John W. Chapman (szerk.): Justification. New York and London, New York University Press, 1986. 54.

${ }^{4}$ Martin H. REDISH: Freedom of Expression. A Critical Analysis. Charlottesville, The Michie Company, 1984. 19.
} 
elve drámaian elbukik, mivel szavaink e tekintetben általában veszélyesebbek, mint fizikai aktusaink. Szóbeli rábírással meghatározóbb, érdemibb hatással tudunk lenni egy jövőbeli sérelem bekövetkeztére, mint például valamilyen tárgyi eszköz puszta biztosításával. ${ }^{5}$ Schauer szerint a tapasztalat abban az esetkörben is cáfolja a kisebb ártalom gondolatát, amikor szavaink közvetlenül bántanak. A népi bölcsesség nem állja meg a helyét: nem lehet elvi jelleggel kijelenteni, hogy a kő vagy a bot által okozott sérelem mindig vagy tipikusan súlyosabb, mint amit szóval vagy vizuális eszközökkel idézünk elő. Szerinte a tétel igazsága sem a sérelem időtartama, sem pedig annak intenzitása felöl közelítve nem támasztható alá általános érvénnyel. Még ha meg is fogadjuk Harlan bíró javaslatát, és hátat fordítunk a minket bántó közléseknek, ${ }^{6}$ a már megszerzett „,seb” sokszor akár lényegesen hosszabban él tovább bensőnkben, mint egy kevésbé súlyos fizikai atrocitás - mondjuk, egy pofon - okozta fájdalom. És bár nehéz elképzelni a legszörnyübb fizikai kínokhoz mérhető mentális szenvedést, a fizikai fájdalmak zöme messze nem éri el ezt a szintet, ezért általános érvényű tétel a sérelem intenzitása alapján sem fogadható el. ${ }^{7}$

Kevésbé analitikusan, viszont nagyon találóan utasítja el a szavak ártalmatlanságának gondolatát Edwin Baker. Meglátása szerint az általa is idézett mondókához képest a valóság az, hogy a szólásszabadság nevében megvédett közlések szinte mindegyikével szemben felhozhatók fájdalmak, sérelmek vagy érdeksérelmek. Baker két példát hoz arra, hogy a szavakkal okozott bántalmakat soha nem szabad alábecsülni. Egyrészt a csoporthoz tartozás miatti elnyomás jelentős részben rasszista kifejezésekben testesül meg vagy nyer megerösítést. Másrészt köztudott, hogy a gyermekek önképére, teljesítőképességére és ezáltal akár egész életére mekkora hatással vannak tanáraik és nevelőik szavai, ami abban is megnyilvánul, hogy a nem megfelelő módon kommunikáló pedagógust jobb helyeken teljesen jogszerüen bocsátják el. Ebben az értelemben a beszéd akár a büntetendő fizikai tettlegesség egyes megnyilvánulásainál is jóval ártalmasabb lehet. ${ }^{8}$

\footnotetext{
${ }^{5}$ Frederick SCHAUER: The Phenomenology of Speech and Harm. Ethics, Vol. 103, No. 4 (July, 1993), 643.

${ }^{6}$ Cohen v. California, 403 U.S. 15 (1971)

${ }^{7}$ SCHAUER (5. lj.) 647-649.

${ }^{8}$ C. Edwin BAKER: Harm, Liberty, and Free Speech. 70 Southern California Law Review 979 19961997, 987-988. A példát továbbvíve Baker ugyanakkor arra is rámutat, hogy a beszédet általában nem büntetik önmagában sérelmes jellege miatt: míg a diákot megverő tanár ma már azonnali fegyelmi következményekre számíthat, addig a lelki sérelmet okozó nevelönek általában nem kell rögtön retorziótól tartania.
} 
Baker álláspontja azért is nagyon tanulságos a számunkra, mert éppen ő az, aki szavaink ártó erejének elismerése mellett is az egyik legmarkánsabb képviselője annak a nézetnek, hogy a szólásszabadság hatálya alá tartozó közléseket sosem szabadna pusztán az általuk okozott sérelemre tekintettel szabályozni. Szerinte a szavak sérelmekhez füződő speciális viszonya nem abban áll, hogy nem képesek ilyet okozni, hanem abban a folyamatban, ahogyan okozzák őket. A kommunikáció a sérelmet kiváltó hatásmechanizmusban különbözik radikálisan egyéb kártékony tettünktől. Baker e tekintetben azt hangsúlyozza, hogy megszólalásaink sosem önmagukban és közvetlenül ártalmasak, hanem mindig a befogadó mentális közvetítésével (mental mediation). A beszéd önmagában mindig csupán a közlő személyes véleményét közvetíti, abból sérelem annyiban származhat, amennyiben a hallgatóság egy bizonyos módon, és nem pedig másképp, reagál - a kritikai helyett például az áldozat szerepébe helyezve magát. ${ }^{9}$

Baker álláspontja tulajdonképpen Judith Thomson filozófiáját konkretizálja és alakítja tovább a szólásszabadság teóriájában. Thomson különbséget tesz azok között a fájdalmak között, amelyeket saját meggyőződéseink közvetítésével érzékelünk (beliefmediated distress), és azok között, amelyeket ilyen közbenső tényező nélkül érzünk (non-belief-mediated distress). Utóbbi körbe sorolja például a fizikai fájdalmat vagy azt az érzést, amely rothadt halat szagolva vagy a táblán csikorgó krétát hallva hasít belénk, elöbbi kör pedig többek között az olyan érzéseket öleli fel, mint a félelem, a csalódás, a megszégyenülés, a szomorúság. Thomson fájdalom-tézise (The Distress Thesis) szerint csak arra vonatkozóan fogalmazhatunk meg igényt, hogy mások ne okozzanak nekünk olyan fájdalmat, amelyet nem a saját meggyőződéseink közvetítenek. Az erre a következtetésre vezető egyik megfontolás, hogy a meggyőződéseink által közvetített fájdalmak esetében óriási tere nyílik az irracionalitásnak: jelentős részben maga a meggyőződés teljesen irracionális (például ha azt hisszük, hogy a rák tüsszentéssel terjed), további esetekben pedig bár maga a meggyőződés észszerü, a fájdalom intenzitása azonban már az adott jelenség iránti viszonyunk irracionalitásának tudható be (például a szőnyegünk megrögzött szeretete miatt mélységes szomorúság törhet ránk egy mezei szakadás híre hallatán is). ${ }^{10}$

\footnotetext{
${ }^{9}$ BAKER (8. lj.) 989-992.

${ }^{10}$ Judith Jarvis ThOMSON: The Realm of Rights. Cambridge-London, Harvard University Press, 1990. 250-259.
} 
Baker tehát mindebből azt a következtetést vonta le a szólásszabadság számára, hogy noha szavaink kétségkívül képesek ártani, az ártalom bekövetkeztének különleges folyamatára tekintettel ezt a szempontot mégis helyesebb számüzni a doktrínából.

A szólásszabadság-irodalomban megint csak Schauer volt az, aki az ártalmatlanság tanának ezt a „kistestvérét” analitikus módon igyekezett cáfolni. Álláspontja szerint a fizikai és mentális fájdalmak között meglévő különbség ebben az értelemben sem tekinthető oly mértékben minőséginek, ami radikálisan eltérő jogi rezsimet indokolna. A fizikai fájdalmak esetében szintén saját idegsejtjeink közvetítik a fájdalmat, és a közvetítő közeg kiiktatása mindkét körben igencsak bonyolultnak tünik. Mentális sérelmeink jellemzően saját meggyőződéseink és a világról meglévő tudásunk eredményeképpen alakulnak ki bennünk, és egyik félretétele sem tünik reálisabb elvárásnak, mint idegsejtjeink kordában tartása (például oly módon, hogy füldugót helyezünk be, valahányszor krétával írnak táblára körülöttünk). Meggyőződéseink kikapcsolása vagy lecserélése a legmegengedőbb esetben is hosszú folyamat, és Schauer nem lát megfelelő indokot arra, hogy a „fájdalmak terhének elosztásakor” valakit felelőssé tegyenek adott meggyőződés viseléséért. Vagy legalábbis nem látja indokoltabbnak, mint annak elvárását, hogy valaki minden elképzelhető intézkedést tegyen meg előre a fizikai fájdalmak elkerülése érdekében. ${ }^{11}$

Baker álláspontjával szemben még egy ponton erős ellenérvek hozhatók föl. Kétségtelenül letisztult elméleti konstrukció, hogy szavaink minden esetben csak személyes értékeinket, meggyőződésünket, véleményünket közvetítik, és sérelem okozására kizárólag további szereplők reakciója révén válnak alkalmassá. A konstrukció tisztasága elvi igazságában rejlik. Ebből azonban az emberi viszonyainkat és társadalmi együttélésünket szabályozó jog számára nem adódik Baker következtetése, hogy a szólásaink nyomán kialakuló károkat nem lehet a beszélő terhére róni. E következtetés elfogadása ugyanis azt a további feltételt is magában foglalná, hogy a szabályozást helyes lenne laboratóriumi körülményekhez szabni, ahol a beszélő minden esetben jogosan tekinthetné a hallgatóságát sztoikus bölcsek

\footnotetext{
${ }^{11}$ SCHAUER (5. lj.) 649-652.
} 
gyülekezetének, nem számolva a közösségi élet ennél lényegesen színesebb valóságával. $^{12}$

A szólások ártó képességéről folytatott vita legfontosabb elméleti szempontjainak igazságáról nagyon nehéz intuícióinktól és előzetes feltevéseinktől teljes mértékben független döntést hozni. Megnyugvással tölthet azonban el minket, hogy az a két tétel, ami a doktrína magyarázatához majd legszükségesebb és egyben leghasznosabb lesz a számunkra, összességében a szélsőségek elkerülésére szólít fel minket. Az elméleti diskurzus mindkét oldaláról merítenünk kell ugyanis ahhoz, hogy értelmezni tudjuk a körülöttünk zajló folyamatokat. Egyfelől a szólással okozott ártalmakat tagadó vagy azokat a jogi mérlegelésből egyéb okból teljesen számüző nézet - általánosító formájában - elkerülendőnek tűnik. Ha az emberi személyt a maga teljességében, testilelki-szellemi egységében szemléljük, akkor be kell látnunk, hogy a beszéddel okozott immateriális ártalmak valóságosak, és akár fájdalmasak is lehetnek. A szólással okozható lelki sérelem, bántalom léte nem tagadható. Másfelől azonban ugyanilyen hiba lenne tagadni vagy figyelmen kívül hagyni, hogy ez a sérelem más természetü, másképp formálódó, mint fizikai fájdalmaink. Ha a mentális fájdalmak léte nem is spekulatív, konkrét jelenlétük és mértékük általában az.

A szólással okozott ártalmak létéröl és természetéről folytatott elméleti vita nagy hozzájárulása a szólásszabadság diskurzusához, hogy rengeteget tisztít a gondolkodásunkon, ha számba vesszük és elemezzük, miként viszonyul joggyakorlatunk a beszéddel okozott sérelmekhez. Vizsgálódásunk alapvető üzenete lehet, hogy a véleménynyilvánítás értékességének magyarázatát mindenekelőtt nem ártalmatlanságára, hanem valamely szilárdabb igazságra kell alapoznunk.

\section{A szólással okozható sérelmek tipológiája}

A szólásszabadság-doktrína szisztematikus felrajzolásában és megértésében nem csupán annak az alapvető kérdésnek van jelentősége az ártalmak körében, hogy elismerjük-e a szavak ártó képességét és jogi válaszaink mérlegelésében biztosítunk-e bármilyen szerepet a bekövetkező sérelmeknek. Ha ugyanis ezekre a kérdések igenlő

\footnotetext{
${ }^{12}$ A sztoikus hallgatóság terminusra lásd: Henrik EsSUNGER: Stoic listeners? Speech Harms and the First Amendment. 6 Journal of Law and Social Change 552002
} 
választ adunk, akkor a tisztánlátáshoz arra is szükség van, hogy legmeghatározóbb karakterisztikájuk szerint számba vegyük a beszéddel okozható sérelmeket, és azonosítsuk a releváns különbségeket. Aki szerepet szán az ártalmaknak a szólásszabadság doktrínájában, annak meg kell tudnia mondani, hogy miben látja egy adott szólás kártékonyságát. Kommunikációs aktusaink sokszínüsége szerénységre int minket abban a tekintetben, hogy ne kívánjunk kimerítő felsorolásra jutni szavaink ezernyi lehetséges hatásának leírásakor. Azoknak a szempontoknak a kiemelésére azonban mindenképp törekedhetünk, amelyek leginkább segítségünkre vannak az ártalmak szerepének megragadásában.

Egyetérthetünk Schauerral abban, hogy ameddig nem ragadtuk meg valamelyest a különböző sérelmek természetét, szavakhoz kötődő lényegét, addig nem is tudunk értelmesen dönteni a szólásszabadság gyakorlatában betöltött helyükröl. ${ }^{13}$ Első lépésként mindenekelőtt tudatosítanunk kell, hogy ezek az ártalmak korántsem egyívásúak, hanem lényegi pontokon különböznek egymástól. Schauer az amerikai Legfelső Bíróság példái alapján a sérelmek triászát (trilogy of harms) állítja föl, nem vindikálva kimerítő erőt osztályozásának. ${ }^{14}$

Az első csoportot a motiváló erejű szólások ártalmai (harms of advocacy) alkotják. A változatos néven illethető sérelmek (pártolás, meggyőzés, befolyásolása, megkönnyítés stb. ártalmai) közös jellemzője, hogy akkor következnek be, amikor a beszélő szavainak hatására hallgatósága sérelmes cselekményeket hajt végre. Schauer az osztályozás erejéig nem tesz különbséget aszerint, hogy a sérelmek a beszélő szándékával összhangban vagy attól függetlenül keletkeznek, illetve hogy a véleménynyilvánítás és a sérelmek bekövetkezte mennyire áll szoros kauzális kapcsolatban egymással. A lényeget abban ragadja meg, hogy ezekben az esetekben a kommunikatív aktus olyan cselekmények elkövetésének esélyét növeli, amelyek sérelmes jellegét konszenzus övezi. A beszéd hallgatója harmadik személynek egyértelműen kárt okoz. ${ }^{15}$ Érdemes megemlíteni, hogy Schauer a közelmúlt legfelső bírósági gyakorlatából a videojátékok korlátozásával kapcsolatos jogesetet hozza érdekes példaként, ${ }^{16}$ amely egyszersmind arra is kiváló alkalom a számára, hogy rámutasson: a szóban forgó sérelem eltérő azonosítása eltérő következtetésekre

\footnotetext{
${ }^{13}$ Frederick SCHAUER: Harm(s) and the First Amendment. 2011 The Supreme Court Review 812011. 107.

${ }^{14}$ SCHAUER (13. lj.) 97-104.

15 Schauernek ezt a csoportját így a sérelmek „háromszemélyes konstellációjaként” is azonosíthatjuk.

${ }^{16}$ Brown v. Entertainment Merchants Association, 564 U.S. 786 (2011)
} 
vezethet. Ha az erőszakos videojátékok káros hatását pusztán a képernyő előtt ülő gyermek személyiségét érő ártalomban látjuk, akkor sokkal erősebb a szülö felelősségét és az erőszakos tartalomról való elkapcsolás lehetőségét hangsúlyozó érv, mintha a személyiségtorzuláson túl az így kezelhetetlenné váló gyermek másokat sújtó erőszaktevéseit tartjuk szem előtt. Látni kell azonban, hogy - amint az a Legfelső Bíróság érvelésében központi hangsúlyt kapott - ez esetben mindig nagy jelentőségűvé válik a szó és következménye közti kauzális kapcsolat.

Schauer második csoportjába a szóbeli támadásokkal okozott sérelmek (harms of verbal assault) tartoznak. Ezekben az esetekben a szavak sértettje nem valamely harmadik fél, akinek a beszéd hallgatója kárt okoz, hanem maga a beszéd hallgatója. A sértett fél nem a beszéden túli további tett elszenvedője, hanem maga a beszéd az, ami számára szenvedést okoz. Schauer szerint nem arról van szó, hogy - a híres Chaplinsky ügy ${ }^{17}$ indokolásának fordulatával élve - bizonyos szavak közlésüknél fogva, önmaguktól (,by their very utterance”) bármely helyzetben ártalmasak volnának, hanem arról, hogy bizonyos körülmények között maguk a kifejezések is (nem pedig csak a hatásukra végrehajtott egyéb tettek) képesek sérelmet okozni.

Végül a sérelmek külön típusát alkotják Schauer szerint a résztvevői ártalmak (participant harms). Ezekben az esetekben a sérelem azokat éri, akik a kommunikatív aktusban (tipikusan audiovizuális tartalmak készítésében) részt vesznek, és sérelmük teljes mértékben független attól, hogy akár egyetlenegy befogadóhoz ténylegesen el is jutott-e a szóban forgó tartalom. Bár a szólásszabadság történetében ez az esetkör nem bír az előző két csoporthoz mérhető jelentőséggel, nagyon fontos kérdéseket és sajátos sérelmeket fed le, ezért önálló említést érdemel. Az amerikai gyakorlat példája a gyermekeket szerepeltető pornográf tartalom, amelynek tiltása a résztvevői ártalmakra tekintettel egyértelműen alkotmányosnak minősült, ${ }^{18}$ és a pornográfiával szembeni érveléseknek ennél szélesebb körben is erős eleme, hogy súlyosan sérelmes a benne résztvevők számára. A közelmúltban pedig az állatok kegyetlen kínzásával készült videók vetettek föl hasonló jellegü kérdéseket. ${ }^{19}$

Érdemes emlékeztetni arra, hogy Baker logikájában Schauer első két csoportja a lényeget tekintve nem különbözik egymástól: megszólalásaink sosem önmagukban és

\footnotetext{
${ }^{17}$ Chaplinsky v. New Hampshire, 315 U.S. 568 (1942)

${ }^{18}$ New York v. Ferber, 458 U.S. 747 (1982)

${ }^{19}$ United States v. Stevens, 559 U.S. 460 (2010)
} 
közvetlenül ártalmasak, hanem mindig a befogadó mentális közvetítésével. Akár harmadik személyt érő, akár magát a hallgatót érintő sérelemről van szó, a beszédből csakis annyiban származhat ez, amennyiben a hallgatóság sérelmet generáló módon reagál: erőszakos tettre szánja el magát, avagy az áldozat szerepébe helyezkedik. ${ }^{20}$ Bakernek ez a logikája azonban ugyanúgy elszigetelt maradt, mint az ártalmak jelentőségét a jogi mérlegelésből kiiktatni szándékozó végső következtetése.

A szólásszabadság elméletét és gyakorlatát ugyanis éppen ennek a kétfajta sérelemtípusnak a leírása, megkülönböztetése és kapcsolata foglalkoztatja leginkább. Az elemzések arra is kiválóan rávilágítanak, hogy a véleménynyilvánítás doktrínájában kulcsfontosságú kérdéssé válik a szóban forgó sérelem azonosítása és értékelése. Nem véletlen, hogy a számunkra legtanulságosabb gondolatok a véleményszabadság egyegy klasszikus problémája kapcsán fogalmazódtak meg.

Robert Post a szavakkal járó ártalmakat a blaszfémia kérdéskörébe ágyazva ${ }^{21}$ igyekezett megragadni. ${ }^{22}$ A sérelmek egyik jellemző csoportját szerinte azok a következmények alkotják, amelyeket a beszéd esetlegesen, bizonyos körülmények között képes kiváltani (contingent harms). Ebben az esetben szavaink olyan, jellemzően erőszakos fejleményekkel járnak, amelyek mindenképpen szabályozást igényelnek. Míg az 1920-as évek amerikai doktrínája ennek alapján szabad utat adott minden olyan közlés korlátozására, amely „hajlamos” volt ilyen sérelem előidézésére (bad tendency-teszt), ${ }^{23}$ addig a híres ,nyilvánvaló és közvetlen veszély” (clear and present danger) tesztje radikálisan leszükítette a jog számára releváns okozati összefüggést a beszéd és annak káros következménye között. ${ }^{24}$ Ebben a körben tehát a mérlegelés középpontjában az áll, hogy a szavak és a felmerülő veszélyes fejlemények kellően szoros kauzális kapcsolatban vannak-e egymással. Ha ez a kapcsolat nem ragadható meg teljesen egyértelmüen, akkor az amerikai doktrína nem engedi, hogy a jog az ártalmak terhét a beszélőre hárítsa. ${ }^{25}$

\footnotetext{
${ }^{20}$ BAKER (8. lj.) 989-992.

${ }^{21}$ Robert C. Post: Blasphemy, the First Amendment and the Concept of Intrinsic Harm. 8 Tel Aviv University Studies in Law 2931988

${ }^{22}$ Post ugyanakkor hasonlóan fontosnak tartja a szóba jövő sérelmek elkülönítését és elemzését a rasszista beszéd jogi kezelésekor is. Robert C. POST: Racist Speech, Democracy, and the First Amendment. 32 William and Mary Law Review 267 1990-1991

${ }^{23}$ Debs v United States, 249 U.S. 211 (1919)

${ }^{24}$ Brandenburg v. Ohio, 395 U.S. 444 (1969)

${ }^{25}$ Post (21. lj.) 293-294.
} 
Mindehhez képest teljesen más jellegü kérdéseket vetnek föl Post szerint azok a sérelmek, amelyek nem a beszéd okozta valamely veszélyes fejleményben rejlenek, hanem magában a beszédben (intrinsic harm). A már említett Chaplinsky-ügy nevezetes kifejezése szerint ebben az esetben a szavak puszta közlésüknél fogva, önmagukban (,by their very utterance”) vezetnek sérelemre. Az így felfogott ártalmak nem illeszthetők be abba a fogalmi keretbe, amely a beszéd és következményei közti kauzális kapcsolatra koncentrál, hanem önálló elemzést igényelnek. Ez a vizsgálat annál inkább sürgető Post szerint, mert a szólásszabadság hagyományosan nagy érdeklődést keltő problémái közül számos (a becsmérlés, a pornográfia, az obszcenitás, a sértő beszéd) ezek körül a sérelmek körül forog. A dolog pikantériája ugyanakkor, hogy a „Szavakban bennerejlő sérelem” kategóriáját rendkívül nehéz úgy felfogni, hogy az összeegyeztethető legyen a szólásszabadság alapvető tételével, mely szerint nem lehet szavakat tiltani pusztán azon az alapon, hogy nem szeretnénk hallani öket. ${ }^{26}$

Mindazonáltal Post kulcsfontosságú szempontokkal gazdagítja az ártalmak e típusával kapcsolatos megértésünket. Felfogásában az ilyen sérelmek ahhoz a kérdéshez vezetnek, hogy a jog a társasági érintkezés milyen szabályait (social norms) kényszerítse ki. Azt az érzésünket vagy meggyőződésünket ugyanis, hogy egy megszólalás elfogadhatatlan, türhetetlen, kizárólag a megfelelő, illő kommunikálásra vonatkozó társas szabályaink befolyásolják. Ennek alapján Post egyrészt elkülöníti egymástól a „bennerejlő sérelmek” két dimenzióját. Az első az egyéni felháborodás, megbotránkozás és megrázkódtatás érzése, amely szintén ezekben a normákban gyökerezik, mivel minden személyiség jelentős részben az őt érintő társas érintkezésben formálódik és értelmeződik. A másik sérelem közösségi, mivel a társasági szabályok megsértése természetszerüen közösségi normaszegést is jelent. ${ }^{27}$

Másrészt a blaszfémia példáján keresztül Post a társasági normák érvényesítésének három eltérő módját szemlélteti. Álláspontja szerint az egyetlen többségi közösség normáit mindenkire ráerőltető első út (assimilation) - legalábbis szélsőséges formájában - járhatatlan a szólásszabadság számára, mivel végső soron az igazságot kutató identitáskeresőket teljes mértékben megfosztja a fennálló társasági normák megkérdőjelezésének lehetőségétől. A másik két modell egyaránt összeegyeztethető a véleményszabadság eszméjével. Mind a sokféle közösség normáit egyidejűleg

\footnotetext{
${ }^{26} \operatorname{POST}(21$. lj.) 294-295.

${ }^{27}$ POST (21. lj.) 321.
} 
érvényesülni engedő és adott esetben megvédő megoldás (pluralism), mind pedig az egyénekkel szemben - ebben az értelemben - közösségi normákat egyáltalán nem érvényesítő modell (individualism) teret enged annak, hogy a társadalom tagjai kellő szabadsággal keressék a számukra érvényes igazságot. Az Egyesült Királyság (pluralism) és az Egyesült Államok (individualism) eltérő modell-választását például Post azzal magyarázza, hogy míg a brit társadalomban a csoportidentitások stabilabbak és inkább állapothoz, semmint választáshoz kötődnek, addig az amerikaiban a közösségek képlékenyebbek és erősebben függnek az egyéni elhatározásoktól. ${ }^{28}$ Ennek hatása figyelhető meg azon a gyakorlaton, amely vallási csoportok érzékenységének nem enged teret a szólásszabadság doktrínájában, ${ }^{29}$ ugyanakkor nem zárja ki érintkezési normák érvényesítését a konkrét személyközi viszonyok tekintetében. ${ }^{30}$

A szólások okozta ártalmak körében mindenképpen érdemes még szemügyre vennünk Ronald Dworkinnak a pornográfia szabályozásával összefüggésben kifejtett érveit. ${ }^{31}$ Dworkin a témát átfogóan feldolgozó bizottsági jelentés ${ }^{32}$ elemzésekor többek között az anyagnak azt az alapelvét járja körül, amely szerint egészen addig nincs helye jogi szabályozásnak, ameddig a szóban forgó magatartás sérelmet nem okoz valakinek (harm-condition). Igen ám, csakhogy éppen azon múlik minden, hogy mit tekintünk sérelemnek. A jelentés végső javaslatait egyébként alapvetően nem vitató Dworkin ítélete szerint az anyag sérelemre fókuszáló szemlélete alkalmatlan arra, hogy a benne foglalt ajánlások meggyőző igazolását nyújtsa. Érvelésének egyes pontjai az ártalmak tipológiája szempontjából is rendkívül tanulságosak.

Egyrészt leszögezi, hogy ha sérelem alatt csak a másoknak okozott testi bántalmat, a mások tulajdonán ejtett kárt, illetve mások pénzügyi érdekeinek sérelmet - azaz kizárólag materiális károkat - értenénk, akkor oly mértékben leszükítő fogalmat kapnánk, ami alkalmatlan az angolszász jog jelentős részének magyarázatára.

Másrészt megállapítja, hogy hasonlóan képtelen eredményre vezet, ha a sérelem kategóriájába a másoknak okozott bármely lelki megrázkódtatást (mental distress, disgust-harm) is beleértjük, mivel az így végtelenül tágra nyitott fogalom hasztalanná válik a tudományos elemzés számára. A felháborodás egyébként sem jelöl ki

\footnotetext{
${ }^{28} \operatorname{POST}(21$. lj.) 295-300., 323.

${ }^{29}$ Cantwell v. Connecticut, 310 U.S. 296 (1940)

${ }^{30}$ Chaplinsky v. New Hampshire, 315 U.S. 568 (1942)

${ }^{31}$ Ronald DWORKIN: Is There a Right to Pornography? 1 Oxford Journal of Legal Studies 1771981

${ }^{32}$ Report of the Committee on Obscenity and Film Censorship, vagy más néven Williams-jelentés
} 
számunkra határvonalakat, így például nem meggyőző a jelentés arra vonatkozó javaslata, hogy ne vegyük számításba azokat a megbotránkozásokat, amelyek a mások erkölcstelenségének puszta tudatán alapulnak, viszont számoljunk azokkal, amelyek az ilyen tartalmakkal való szembesülés eredményei. Dworkin szerint ez az ajánlás csupán annak helyes belátását tükrözi, hogy valahol meg kell állni az érzékenységek figyelembevételekor, de a határok meghatározásában ezek az érvek nem nyújtanak segítséget. $^{33}$

Dworkin végül - az egyéni és közösségi sérelmek Postnál látott megkülönböztetésével némiképp rokon módon - az ártalmak harmadik lehetséges típusát azonosítja a pornográfia kapcsán, amikor is a jelentés - például az élő szexshow-k tiltásával összefüggésben - abból indul ki, hogy a sérelem nem (csupán) az egyéni érzékenységeken ejt csorbát, hanem a társadalmi és kulturális környezetet (is) rombolja. Az ilyen ártalomnál azonban szükségszerüen merül föl a kérdés, hogy a szabályozás meggyőző érvekre, mindenekelőtt belátható konkrét hatásra vagy okozati kapcsolatra tud-e hivatkozni. ${ }^{34}$ Nem tekinthető meggyőzőnek például, ha ez alapján az érvelés alapján éppen azokat az élő show-kat engedjük tiltani, amelyeknek az általános környezetre gyakorolt hatása egészen biztosan rendkívül csekély. ${ }^{35}$

Nagyon tanulságos látni, hogy összességében Dworkin nem amellett érvel, hogy a pornográfiát szabályozni kívánó jogalkotó tegye félre az ilyen tartalmak ártalmasságáról vallott nézeteit, hanem hogy a korlátozás szükséges határait elsődlegesen ne sérelmekre, hanem az érintett szabadságra, jelen esetben a magánélethez való jogra fókuszálva húzza meg. Ennek megfelelően nem utasítja el eleve a jelentésnek azokat a javaslatait, amelyek a pornográf tartalmak közösségi térben való szabályozása mellett érvelnek, de számon kéri azokat a pontokat, amelyek nem kellő hangsúllyal veszik figyelembe a magánélet szabadságának kívánalmait. ${ }^{36}$

Dworkin szemlélete a pornográfián jócskán túlmutató érvénnyel bír számunkra: a szólásszabadság doktrínája nem azt várja el tőlünk, hogy ne törődjünk a szavainkkal okozható sérelmekkel, hiszen azok figyelembevétele nélkül nem is tudjuk magyarázni

\footnotetext{
${ }^{33}$ DWORKIN (31. 1j.) 187-188.

${ }^{34}$ A kauzális kapcsolat fontosságát egyébként frappánsan ragadja meg az e fejezetben általam nem hivatkozott Ely, aki szerint azért az okozati kapcsolatnak van döntő jelentősége, mert a kormányzat szinte mindig tud valamilyen káros következményre mutogatni. John Hart ELY: Flag Desecration: a Case Study in the Roles of Categorization and Balancing in First Amendment Analysis. 88 Harvard Law Review 1482 1974-1975. 1497.

${ }^{35}$ DWORKIN (31. lj.) 182.

${ }^{36}$ DWORKIN (31. lj.) 197-199.
} 
a körülöttünk lévő szociológiai és jogi valóságot, hanem azt, hogy sose tévesszük szem elől a véleménynyilvánítás jogának kitüntetett jelentőségét. A szólásokat nem ártalmatlanságukra tekintettel oltalmazzuk oly nagyon, hanem éppen az okozható bántalmak ellenére.

\section{Az ártalmak értékelésének alaptételei a magyar doktrínában}

Az Alkotmánybíróság gyakorlatát elemezve teljesen nyilvánvaló, hogy a magyar doktrínában a szólásszabadság nem ártalmatlansága miatt nyer kiemelt védelmet. A nagy ügyek izgalmas kérdésévé nem önmagában a sérelem léte válik, hanem az, hogy milyen sérelemmel állunk szemben: mire vonatkozik, miként ragadható meg, és mely szempontok alapján található meg a helye az alkotmányjogi mérlegelésben. Az alábbiakban a gyakorlatnak azt a két tételét járjuk körül, amely leginkább segítségünkre lehet az ártalmak szerepének meghatározásában. A két tétel némiképp eltérő természetü, de szorosan összefügg egymással. Az első inkább a sérelmek módszertani szabályaként lehet kulcsfontosságú a számunkra, míg a másik a mérlegelés alapvető szemléletét meghatározva arra irányítja a figyelmünket, hogy az értékelés középpontjába ne sérelmeket, hanem jogokat állítsunk. E két tétel vizsgálatakor egyrészt a fenti elméleti szempontokra, másrészt azokra az ismert szólásszabadság kérdésekre támaszkodhatunk, amelyek jelentőségüket a legjobban érzékeltetik.

\subsection{A sérelem szintje}

Az Alkotmánybíróság szólásszabadság-doktrínájának egyik legnagyobb jelentőségü generális szabályát a szavakkal okozott bántalmak értékelésének módszereként is felfoghatjuk. A 30/1992. (V. 26.) AB határozat fogalmazta meg elsőként azt a tételt, hogy „[a] vélemény szabadságával szemben mérlegelendő korlátozó törvénynek nagyobb a súlya, ha közvetlenül másik alanyi alapjog érvényesítésére és védelmére szolgál, kisebb, ha ilyen jogokat csakis mögöttesen, valamely »intézmény« közvetítésével véd, s legkisebb, ha csupán valamely elvont érték önmagában a tárgya 
(például a köznyugalom)."37 A konkrét szövegezés a véleménynyilvánítás jogával konkuráló alkotmányos jogok és értékek felöl közelít a mérlegeléshez, de ez a szabály egyben a szólások ártalmainak helyét is kijelöli az értékelésben. Ennek felismerése azért bír nagy jelentőséggel, mert a mindennapi élet hozta jogeset-alapú vitákban a szólásszabadságnak nagyon gyakran nem elvont alkotmányos értékekre, hanem sérelmekre fókuszáló érvekkel kell szembenéznie. Ezeknek az érveknek az erejét azonban a doktrína nem bízza pusztán a szabad belátásra és a konkrét tényállás „átélhetőségének mértékére”, hanem az idézett szabály formájában a mérlegelés zsinórmértékét adja meg számunkra.

Teljesen világos, hogy a magyar gyakorlat egyik legmarkánsabb tételével állunk szemben, amely a jogrendszer egészére kiterjedően és meghatározó jelleggel kíséri végig az alkotmánybírósági döntéseket. Az Alaptörvény hatálybalépése előtt megtaláljuk szinte valamennyi jelentős szólásszabadság-határozat indokolásában, ${ }^{38}$ jellemzően nem csupán formális hivatkozásként, hanem az érvelés érdemi szempontjaként. A polgári jog körében mozgó 96/2008. (VII. 3.) AB határozat összegző és egyben magyarázó megállapítása szerint „[a]z Alkotmánybíróság gyakorlata következetes abban, hogy a véleményszabadság korlátozhatóságát és annak mértékét a jogsértő magatartás és az okozott alanyi jogsérelem közötti viszony intenzitása határozza meg. Alanyi jogban okozott sérelem a kommunikációs anyajog súlyosabb korlátozását indokolja, ugyanakkor az alanyi jog közvetett sérelme, avagy ha a megsértett védett jogi tárgy nem hozható összefüggésbe alanyi jog sérelmével, a véleménynyilvánítás szabadsága kevéssé vagy egyáltalán nem korlátozható."39

A tétel az utóbbi években két tekintetben még inkább bebetonozta a helyét a magyar doktrínában. Egyrészt a 7/2014. (III. 7.) AB határozat világossá tette, hogy az Alkotmánybíróság az Alaptörvény rendelkezéseinek értelmezésekor is irányadónak tartja a sérelmek elvontságának jelentőségére utaló fordulatot. Az indokolás amellett, hogy a mérlegelés általános szabályaként említi a formulát, ${ }^{40}$ olyan horderejü kérdések feloldásának kulcsaként hivatkozik rá, mint az emberi méltóság és a szólásszabadság sokrétü ütközése. ${ }^{41}$ Másrészt egyértelművé vált az is, hogy a testület a tételt nemcsak

\footnotetext{
${ }^{37}$ 30/1992. (V. 26.) AB határozat, Indokolás V.1., ABH 1992, 167, 178.

38 A teljesség igénye nélkül a tétel megerősítésére lásd pl. 36/1994. (VI. 24.), 20/1997. (III. 19.), 18/2000. (VI. 6.) és 57/2001. (XII. 5.) AB határozatok

${ }^{39}$ 96/2008. (VII. 3.) AB határozat, Indokolás III.2.3., ABH 2008, 816, 823.

40 7/2014. (III. 7.) AB határozat, Indokolás [42]

${ }^{41}$ Uo., Indokolás [24]
} 
az alkotmányos értékek egymáshoz illesztésének absztrakt folyamatában tartja mérvadónak, hanem a konkrét jogeset megoldására irányuló jogalkalmazás értelmezési szabályaként is. A fordulat így vált az érvelés központi elemévé az alkotmányjogi panasz nyomán született 3/2015. (II. 2.) és 3264/2016. (XII. 14.) AB határozatok indokolásában. $^{42}$

Az alábbiakban arra teszek kísérletet, hogy a gyülöletbeszéd (uszítás és gyalázkodás) példáján szemléltessem, a fenti szabály miként válhat perdöntővé a szóban forgó sérelmek (vagy azok veszélyének) pontos azonosításában és ezáltal konkrét jogalkalmazói mércék kidolgozásában. A sérelmekre vonatkozó szempontokat használva eközben megpróbálom - a lehetőségekhez mérten - doktrínába illeszteni a fősodortól eltérő, azt kiegészítő értelmezéseket. Meggyőződésem ugyanis, hogy ameddig értelmes magyarázatot tudunk rájuk találni, addig a kivételeket nem ignorálni, hanem magyarázni kell, annak érdekében, hogy a gyakorlat a maga összetettségében álljon előttünk. Ezzel éppen nem a fősodor gyengítésében segédkezünk, hanem annak hiteles képviseletéhez kínálunk érveket.

\subsubsection{A szólás és veszélyes következménye (uszítás és rémhírterjesztés)}

Láthattuk, hogy a beszéd lehetséges ártalmaival összefüggésben a szólásszabadság irodalmának egyik nagyívű narratívája a másokat cselekvésre indító közlésekkel foglalkozik. Post (contingent harm), Dworkin (physical damage) és Schauer (harm of advocacy) egyaránt magától értetődőnek tartja, hogy jogi szabályozásra van szükség azokban az esetekben, amikor szavaink másokat veszélyes, erőszakos tettekre sarkallhatnak. Bár a valamilyen korlátozás léte ilyenkor nem tünik vitathatónak, az már korántsem egyértelmü, pontosan mely esetekben, mely körülmények között van helye a jogi fellépésnek. Ahogy Post és Schauer kiemeli, ebben a körben a szólás és a vele elöidézhető sérelem közti kapcsolat intenzitása kerül a figyelem középpontjába: meg kell határoznunk, hogy mennyire szoros összefüggést követelünk meg a beavatkozáshoz. Az amerikai joggyakorlat a már említett nyilvánvaló és közvetlen

\footnotetext{
42 3/2015. (II. 2.) AB határozat, Indokolás [24], illetve 3264/2016. (XII. 14.) AB határozat, Indokolás [38] és [41]
} 
veszély (clear and present danger) próbájára támaszkodik, ${ }^{43}$ míg az itthoni elemzések, mint látni fogjuk, eltérő eredményre jutnak a magyar mérce azonosításában. A kérdéskör legnagyobb jelentőségü problémájaként a gyülöletre uszítás tesztjét járjuk körül, amelynek során azonban a rémhírterjesztés esetének példája is fontos szerephez jut.

A szegletkő a véleménynyilvánítás szabadságának eszményét kibontó 30/1992. ( $V$. 26.) AB határozat. Máig ez az a határozat, amely a legszélesebb összefüggéseiben elemzi a gyülölködő magatartásokat, ezért természetes, hogy a későbbi döntések az ebben foglalt értelmezési szempontok további kifejtésére és pontosítására fókuszálnak. Az Alkotmánybíróság e precedense nyilvánvalóvá teszi, hogy a gyülöletbeszéd legszélsőségesebb megnyilvánulásai esetén a büntetőjogi tiltás sem tekinthető eltúlzottnak. A gyülöletkeltés történelmi tapasztalatait, társadalmi következményeit és tartalmi jellemzőit elemző gondolatok közül a mérce konkrétabb, alkalmazhatóbb megfogalmazásához az az értékelés vezet át, amely szerint a gyülöletkeltés a demokratikus jogállamiság tartalmi jegyeinek (emberek egyenlő méltósága, nemzeti és etnikai kisebbségek védelme, vallás- és lelkiismereti szabadság) olyan tagadása, amely már „az erőszak érzelmi előkészítése”. Az említett tartalmi jegyek tagadását és elutasítását ugyanis enyhébb magatartásokkal is ki lehet fejezni, de az uszító nem akárhogyan, hanem az erőszak, illetve konkrét jogok sérelmének veszélyét okozva teszi ezt meg. Ezt a gondolatot pontosítják azok az értelmezési szempontok, amelyeket az Alkotmánybíróság a büntetőbíróságok több mint százéves, a gyülöletre izgatás elkövetési magatartására vonatkozó gyakorlatából merít. Eszerint izgatás alatt „olyan lázongó kifakadások értendők, amelyek alkalmasak arra, hogy az emberek nagyobb tömegében a szenvedélyeket oly magas fokra lobbantsák, amelyből gyülölet keletkezvén, a társadalmi rend és béke megzavarására vezethet". Az ilyen megnyilvánulások „nem az értelemhez szólnak, hanem az érzelmi világra akarnak hatni, s szenvedélyek, ellenséges indulatok felkeltésére alkalmasak". ${ }^{44}$ Mindezeken túl azonban az Alkotmánybíróság a gyülöletre uszítás megítélésében azt tartja perdöntőnek, hogy nagyszámú egyéni jog megsértésének veszélyét hordozza. Az

\footnotetext{
${ }^{43} \mathrm{Az}$ amerikai doktrína fejlődésének összefoglaló áttekintésére lásd pl.: UDVARY Sándor: Alkotmányos médiajog? Az elektronikus média jogának elemzése az amerikai és a magyar alkotmánybiráskodási gyakorlat tükrében. Budapest, Károli Gáspár Református Egyetem, 2008. 54-58.

44 30/1992. (V. 26.) AB határozat, Indokolás IV.5., ABH 1992, 167, 177.
} 
uszító egyéni jogok veszélyeztetésével borítja fel a társadalmi békét, azaz a köznyugalmat nem elvont alkotmányos értékként sérti csupán. ${ }^{45}$

Az Alkotmánybíróság határozatát elemzők között azonban nincs egyetértés arról, hogy ebben a döntésében a testület milyen veszélyt is követelt meg a büntetőjogi korlátozhatósághoz. Egyelőre durván leegyszerüsítve a kérdést, a vitatkozók abban nem értenek egyet, hogy az uszítás mércéje az Egyesült Államok Legfelső Bíróságának gyakorlatából ismert nyilvánvaló és közvetlen veszély (clear and present danger) tesztjével azonos-e. Az egyik álláspont szerint az Alkotmánybíróság által megfogalmazottaknak döntő eleme az amerikai teszt: noha az Alkotmánybíróság határozatában nem egyértelmü utalásként jelenik meg az ominózus mérce, az uszítással támadott egyéni jogoknak nyilvánvaló és közvetlen veszélybe kell kerülniük ahhoz, hogy az alkotmányosnak talált tiltás életbe léphessen. ${ }^{46}$ Mások azt hangsúlyozzák, hogy az Alkotmánybíróság a gyülöletre uszítás értelmezésekor nem követelte meg az érintett jogok ilyen fokú veszélyeztetését, hanem beérte távolabbi veszély fennállásával. ${ }^{47}$ Annak ellenére, hogy a vitát közvetlenül eldöntő meghatározást nem tartalmaznak, nagyon tanulságosak az Alkotmánybíróság akkori elnökének, a határozat előadó alkotmánybírájának, Sólyom Lászlónak az értelmező mondatai: „Még a "gyülöletre uszítás« alkotmányosnak minősített tényállásához is megjegyezte az Alkotmánybíróság, hogy nem egyedül a köznyugalom megzavarásának intenzitása (a »clear and present danger«) igazolja a véleménynyilvánítás büntethetőségét, hanem az

\footnotetext{
45 Alapvető jelentősége miatt az indokolásnak ezt a részét szó szerint idézem: „A társadalmi rend és béke - a Btk. szóhasználatával a köznyugalom - ilyen megzavarása mögött ott van nagyszámú egyéni jog megsértésének a veszélye is: a csoport ellen felszított indulat fenyegeti a csoporthoz tartozók becsületét, méltóságát (szélsőséges esetben életét is), megfélemlítéssel korlátozza őket más jogaik gyakorlásában is (köztük a szabad véleménynyilvánításban). Az (1) bekezdésben szankcionált magatartás olyan veszélyt hordoz egyéni jogokra is, amelyek a közvetlen tárgyként szereplő köznyugalomnak olyan súlyt adnak, hogy - a IV. pontban történt kifejtés szerint - a véleményszabadság korlátozása szükségesnek és arányosnak tekinthető. Noha a mérlegelés gyakorlati eredménye hasonló, ebben a gondolatmenetben nem csupán a köznyugalom megzavarásának intenzitásáról van szó, amely egy bizonyos mérték fölött (»clear and present danger«) igazolja a szabad véleménynyilvánításhoz való jog korlátozását. Itt az a döntő, hogy mi került veszélybe: az uszítás az alkotmányos értékrendben szintén igen magasan álló alanyi jogokat veszélyeztet.” 30/1992. (V. 26.) AB határozat, Indokolás V.2., ABH 1992, 167, 178-179.

${ }^{46}$ MolnÁR Péter: Az alkotmányos mérce világosabb értelmezése felé. Fundamentum 2004/1. sz. 141146.

${ }^{47}$ HALMAI Gábor: Hátramenetben az alapjogvédelem? Fundamentum 2000/3. sz. 69.; SAJÓ András: A szólásszabadság kézikönyve. Budapest, KJK-KERSZÖV, 2005, 165-174.; KOLTAY András: A „clear and present danger" elv fordulatos története az Egyesült Allamokban és Magyarországon. Magyar Jog 2009/7. sz. 415-423.
} 
uszítás folytán veszélybe kerülő alanyi jogok."48 Ugyanő egy cikkében e veszély természetét a „valós” jelzővel írta le. ${ }^{49}$

A gyalázkodásra vonatkozó büntetőjogi tilalom megsemmisítését követően a jogalkotó több kísérletet is tett a gyülöletbeszéd büntetőjogi korlátozásának újrafogalmazására. A 12/1999. (V. 21.) AB határozat alkotmányellenesnek találta a tényállás kiegészítését a „gyülölet keltésére alkalmas egyéb cselekmény” elkövetési magatartással. Az Alkotmánybíróság ebben a döntésében érdemben nem tett hozzá a témánk szempontjából fontos értelmezési szempontokhoz, viszont megerősítette, hogy a büntethetőség alkotmányos mércéje az uszítás, nem pedig a gyülöletkeltés általában. Mivel az új elkövetési magatartás leszállította volna a büntethetőség küszöbét - és egyébként nem felelt meg az egyértelmüség követelményének -, az Alkotmánybíróság megsemmisítette.

A 18/2004. (V. 25.) AB határozat viszont már érdemben próbálta továbbértelmezni, pontosítani az 1992-es döntésben megjelenő kritériumokat. A törvényhozó újabb próbálkozásában a „gyülöletre uszít” kifejezést „gyülöletre izgat”-ra cserélte, kiegészítette a „,vagy erőszakos cselekmény elkövetésére hív fel” fordulattal, továbbá új tényállásban tiltotta a becsmérlést. ${ }^{50} \mathrm{Az}$ előzetes normakontrollt kezdeményező köztársasági elnöki indítvány kifejtette: „az Alkotmánybíróság ugyan nem szabta az alkotmányosság mércéjéül, hogy a gyülöletre uszítás nyilvánvaló és közvetlen veszélyeztetést idézzen elő, de a konkrét alapvető jogok veszélyeztetettségének reálisan, ténylegesen fenn kell állnia", 51 márpedig a jogalkotó célja - különös tekintettel a törvénymódosítás indokolására - egyértelműen a büntethetőségi küszöb leszállítása. Az Alkotmánybíróság a támadott rendelkezéseket alkotmányellenesnek ítélte. A határozat alapja a gyülöletre uszítás korábban már értelmezett mércéje, ugyanakkor az 1992-es mondatok idézése mellett az indokolás több helyen is olyan megfogalmazással él, amely a büntethetőségi küszöb emelésének irányába mutat. Az

\footnotetext{
${ }^{48}$ SÓLYOM László: Az alkotmánybiráskodás kezdetei Magyarországon. Budapest, Osiris, 2001. 478.

${ }^{49}$ SólyOM László: Szeretetbeszéd, tiszteletbeszéd. Népszabadság, 2001. december 24.

${ }^{50}$ A Btk. 269. §-ának helyébe a következö rendelkezés lépett volna:

269. § (1) Aki nagy nyilvánosság elött valamely nemzet, vagy valamely nemzeti, etnikai, faji, vallási csoport vagy a lakosság egyes csoportjai ellen gyülöletre izgat, vagy erőszakos cselekmény elkövetésére hív fel, bủntettet követ el, és három évig terjedő szabadságvesztéssel büntetendő.

(2) Aki nagy nyilvánosság előtt az emberi méltóságot azáltal sérti, hogy mást vagy másokat a nemzeti, etnikai, faji vagy vallási hovatartozás miatt becsmérel vagy megaláz, vétséget követ el, és két évig terjedő szabadságvesztéssel büntetendő.

${ }^{51}$ Mádl Ferenc köztársasági elnök indítványát lásd: Fundamentum 2004/1. sz. 131-136.
} 
Alkotmánybíróság e határozatában ugyanis már valóban szól a véleménynyilvánítással előidézett veszély közvetlenségéről. ${ }^{52}$

A látszat ellenére az 1992-ben mondottakkal teljes mértékben koherens viszont a határozat érvelése abban a tekintetben, hogy miért nem fogadja el a „szavak cseréjét” („uszít” helyett „,izgat”). A korábbi precedens az uszítást a Curia gyakorlatában kidolgozott izgatással azonosította: úgy, mint az érzelmek felkorbácsolására alkalmas magatartást. Az azóta meghozott bírósági ítéletek azonban az izgatást megkülönböztették az uszítástól, és az előbbi alatt már olyan közléseket értettek, amelyek - szemben az emocionálisan ható uszítással - megnyilvánulhatnak racionális érvek felsorakoztatásával, meggyőzéssel is. A törvénymódosítás indokolása pontosan erre utal, amikor a gyülöletre izgatást mind a racionális mérlegelést, meggyőzést, mind az azonnali, mérlegelés nélküli indulatkeltést magában foglaló fogalomként írja le. Az Alkotmánybíróság ebben joggal látta a büntethetőségi szint leszállítását, és a tiltást kizárólag az érzelmi, indulati, lázongó kifakadások esetére tartotta fenn. A törvénymódosítás további részeit az Alkotmánybíróság - durván leegyszerüsítve - a gyalázkodás alkotmányosságát elvető érvek mentén ítélte alkotmányellenesnek.

A büntetőjogi - és ezzel közvetve a médiajogi - mérce szempontjából figyelemre méltó legutóbbi alkotmánybírósági döntés a 95/2008. (VII. 3.) AB határozat. A törvényhozó a gyalázkodás újabb tényállásával próbálkozott, ami újabb köztársasági elnöki indítvánnyal ${ }^{53}$ előzetes normakontrollra került. Az indítványnak helyt adó döntésében az Alkotmánybíróság a szóban forgó „veszély” általános kritériumaihoz nem tesz hozzá új elemet, az uszítás tesztjét a 2004-es döntés nyomában járva használja. ${ }^{54} \mathrm{Az}$ indokolás ezúttal is több helyen szól a gyülöletbeszéd által előidézett

\footnotetext{
52 „A szabad véleménynyilvánítás jogának korlátozására a »gyülöletre uszítás« esetében az egyéni alapjoggyakorlás sérelme, illetve annak közvetlen veszélye miatt kerül sor.” 18/2004. (V. 25.) AB határozat, Indokolás III.2.2., ABH 2004, 303, 309.

„Az Alkotmánybíróságnak az Abh1.-ben, majd az Abh2.-ben megjelenő álláspontja alapján az olyan ún. legveszélyesebb magatartások esetében korlátozhatja a jogalkotó a kifejezés szabadságát büntetőjogi eszközökkel, amelyek elérik »az emberek nagyobb tömegében a szenvedélyeket magas fokra lobbantó lázongó kifakadás« szintjét, az alkotmányos értékrendben igen magasan álló alanyi alapjogokat veszélyeztetnek, ami egyben a köznyugalom megzavarásához vezethet (e veszély közvetlen és nyilvánvaló).” Uo., Indokolás III.3.2., ABH 2004, 312.

${ }^{53}$ Sólyom László köztársasági elnök indítványát lásd: http://www.solyomlaszlo.hu/ab.2008.html

54 A határozatban más tekintetben viszont nagyon fontos új szempontok jelennek meg: többségi indokolásban itt hozza fel az Alkotmánybíróság a „foglyul ejtett közönség” helyzetét új korlátozási indokként. Vö. 95/2008. (VII. 3.) AB határozat, Indokolás III.3.4., ABH 2008, 782, 789.
} 
veszély közvetlenségéröl, és a „közvetlen és nyilvánvaló veszély” fogalma is megjelenik benne. ${ }^{55}$

Összességében az alkotmánybírósági gyakorlatról azt tartom fontosnak kiemelni, hogy míg a büntetőjogilag tiltható szólások tartalmi jellemzőit nagy következetességgel adja meg (érzelmek felkorbácsolására alkalmas, lázongó, indulatos megnyilvánulások), addig az ilyen jellegű szólások tiltásához elengedhetetlenül szükséges veszélyhelyzet minőségét egymástól némiképp eltérő jelzőkkel írja körül. Egyfelől kétségtelen, hogy a 2004-es és a 2008-as döntések a mérce szigorú, megszorító alkalmazása felé terelik az értelmezést. Másfelől viszont amellett érvelek, hogy a későbbi döntések indokolásában olvasható utalások a „közvetlen és nyilvánvaló veszélyre" valójában továbbra sem jelentik kötelezően e teszt követését a közösség elleni izgatás esetében. Annyit mindenképpen állítok, hogy a teljes joggyakorlatot figyelembe véve van valamekkora mozgástere a jogalkalmazónak. ${ }^{56}$ Itt többről van szó annál, minthogy a döntések maguk is hol így, hol úgy írják körül a büntetendő magatartás okozta veszélyhelyzetet, és ezért a „mondatvadászat” - miként általában a jelen esetben sem vezethet minket helyes eredményre. Sokkal inkább azt hangsúlyozom, hogy a gyakorlatot egészében, alapjaira, illetve az alkotmánybírósági teszt lényegére és összetettségére tekintettel kell megítélnünk, és olyan értelmezésre kell jutnunk, amellyel az uszítás koherensen illeszkedik az Alkotmánybíróság judikatúrájába. Nem gondolom, hogy ne lehetne az alább kifejtettektől valamelyest eltérő értelmezésre jutni, de azt igen, hogy az alkotmánybírósági döntések láncolata megengedi az általam képviselt álláspontot, sőt sok tekintetben éppen ez ad koherens választ a felmerülő kérdésekre.

A koherens válaszok érdekében az Alkotmánybíróság érveléseinek azokat a sarokpontjait kell előtérbe helyeznünk, amelyek a véleményszabadság korlátozásának alapvető kereteit adják. Az indokolásokban megjelenő egyes mondatoknak vagy hangsúlyoknak így önmagukban véve addig van jelentőségük, ameddig ezeken a kereteken belül értelmet nyerhetnek. E tekintetben fontos leszögeznünk, hogy sem a

\footnotetext{
55 „Gyalázkodó kifejezések használata, híresztelése és az ilyen testmozdulat végzése önmagában nem jár az erőszak közvetlenül jelen lévő, világos veszélyével, és egyéni jogok sérelmével sem fenyeget. (...) A gyalázkodás immateriális veszélyeztető vétség, amely esetében a jogsértő eredmény és a közvetlen veszélyhelyzet nem tényállási elem.” Uo., Indokolás III.3.2., ABH 2008, 788.

${ }^{56} \mathrm{Ez}$ a következtetés tökéletesen megfér azzal az állásponttal, amely a jogalkotó esetében már a mozgástér rendkívüli szükösségére figyelmeztet. TILK Péter: A kifejezési szabadság és a gyülöletbeszéd néhány alkotmányjogi vonatkozása. Acta Humana 2005/1. 5., 31.
} 
2004-es, sem pedig a 2008-as határozat nem kívánta meghaladni az 1992-es precedenst. Sőt éppen ellenkezőleg: sürü hivatkozásokkal alátámasztva azt tekintik a joggyakorlat szilárd alapjának, és annak érveit igyekeznek tovább pontosítani. Félreértés ne essék, nem kívánom lebecsülni ezeknek a pontosításoknak a jelentőségét, de annyiban mindenképpen korlátozott a hatásuk, hogy az értelmezésnek az imént perdöntőnek mondott sarokpontjait továbbra is a 30/1992. (V. 26.) AB határozatban találjuk. Az egyik ilyen sarokpont a már említett szabály, hogy „,[a] vélemény szabadságával szemben mérlegelendő korlátozó törvénynek nagyobb a súlya, ha közvetlenül másik alanyi alapjog érvényesítésére és védelmére szolgál, kisebb, ha ilyen jogokat csakis mögöttesen, valamely »intézmény« közvetítésével véd, s legkisebb, ha csupán valamely elvont érték önmagában a tárgya (pl. a köznyugalom).” A szólásszabadságot korlátozó szabályozás megítélésekor és értelmezésekor tehát kulcskérdés, hogy minek a védelmét szolgálja, és így hol helyezhető el ebben a hármas felosztásban. Az értelmezés következő sarokpontja pedig éppen az, hogy a gyülöletre uszítás a korlátozások második körébe tartozik. Egyfelől ugyan nem mások alanyi jogának közvetlen védelmét szolgálja, másfelől viszont nem is a köznyugalom elvont értéke a tárgya. Noha az uszító beszéd - a Btk.-ban elfoglalt helyének megfelelően - a köznyugalmat (is) veszélyezteti, e tekintetben az a döntő, hogy a köznyugalmat nem akárhogyan, hanem mások jogainak védelmén keresztül érinti.

Az alkotmányos mércék koherens tisztázásához tehát világosan meg kell különböztetni egymástól a különböző védelmi szinteket: az önmagában vett köznyugalom esetében szigorúbb feltételek kellenek a korlátozáshoz, mint a „mögöttesen” alanyi jogokat óvó szabályozásnál. Az 1992-es döntés jelzi is a szigorúbb feltételek mibenlétét: a köznyugalom sérelme veszélyének ez esetben nyilvánvalónak és közvetlennek kell lennie. Az Alkotmánybíróság a 18/2000. (VI. 6.) $A B$ határozattal később alkalmazta is ezt a tesztet, amikor a rémhírterjesztés tiltását csak közveszély színhelyén vagy háború idején - mely esetekben a köznyugalom sérelmének közvetlen és nyilvánvaló veszélye kétségkívül fennáll - tartotta alkotmányosnak. Egyéb esetekben a rémhírterjesztés korlátozása nem tekinthető olyan „nyomatékos társadalmi szükségletnek”, „nyomós közérdeknek”, amely büntetőjogi tiltást indokolna. Nem arról van szó, hogy a köznyugalmat az Alkotmánybíróság ne ismerné el alkotmányos értéknek, hanem arról, hogy annak elvont, alanyi jogoktól függetlenített sérelme nem valósít meg ,különösen súlyos érdeksérelmet”, amely a 
szólásszabadság jogának büntetőjogi korlátozásához elengedhetetlen. Ez esetben a büntetőjogi beavatkozás mércéjét a lehető legmagasabbra kell tenni, nyilvánvaló és közvetlen veszélyhelyzetekre szorítva a hatósági fellépést.

Az uszításnak azonban nem ez a tesztje. Tekintettel arra, hogy az uszító alanyi jogokat hoz veszélybe, ebben az esetben már a veszély valamivel enyhébb alakzata is korlátozást indokolhat. Az alanyi jogokat „mögöttesen” is nagyobb védelem illeti meg, mint a köznyugalom elvont értékét, ebből következően csekélyebb mértékü veszélyük is fellépésre vezethet. A veszély e csekélyebb mértékének megragadására a Sólyom László értelmezésében és Mádl Ferenc köztársasági elnöki indítványában használt jelzőket tartom a legpontosabbnak: a konkrét jogokat érintő veszélyhelyzetnek „valósnak”, illetve „reálisnak és ténylegesnek” kell lennie. E jelzők mellé jól illeszkedik még, ha az egyéni jogok „,belátható veszélyéről” beszélünk. Az egyéni jogsérelmek „valós, tényleges, belátható veszélyének” mércéje egyfelől szüken, kifejezetten kontrollálható körülmények között engedi csak meg a hatósági fellépést; másfelől viszont abban a szük körben azért megengedi, így - szemben a nyilvánvalóság, de különösen a közvetlenség követelményével - nem vezet gyakorlatilag alkalmazhatatlan mércéhez. ${ }^{57}$

Két gondolat még arról, hogy oldható-e az ellentmondás, amely a fenti értelmezés, valamint a 2004-es és a 2008-as döntések egyes mondatai között feszül. Egyrészt annak ellenére, hogy a lényeg az egyéni jogok veszélyeztetése - az indokolásoknak azért ,joguk van” az uszítás mibenlétét közvetlenül a köznyugalom szemüvegén keresztül is megvizsgálni és ebben a körben a „közvetlen és nyilvánvaló veszély” szükségét említeni. Nem tipikusan, de elöfordulhat, hogy az uszítás egyéni jogoknak csak távoli, ugyanakkor például utcai erőszaknak komoly veszélyét veti fel - ekkor e veszély közvetlen és nyilvánvaló jellege alapozhatja meg a köznyugalom érdekében való fellépést. Másrészt az érvelésem arra irányult, hogy az alkotmánybírósági gyakorlat egésze - nem pedig egyes mondatok - szempontjából legkoherensebb megoldást keressem. Ez magában foglalja annak figyelembevételét is, hogy a 2004-es és 2008-as döntések kifejezetten szük körben alkalmazható mérce felé terelnek.

\footnotetext{
57 A médiajog példáin ez jól szemléltethető. TöRÖK Bernát: A gyülöletbeszéd tilalmának médiajogi mércéi. Jogtudományi Közlöny 2013/2. sz. 59-72.
} 


\subsubsection{A bántó szavak: a közösségeket sértő beszéd}

A szélesebb értelemben vett gyülöletbeszéd problémaköre az erőszakos következmények vizsgálata mellett arra is alkalmat nyújt, hogy körbejárjuk, miként viszonyul a magyar doktrína azokhoz az immateriális ártalmakhoz, amelyek a bántó beszéd elhangzásához kötődnek. Jelen vizsgálatunkkal a szavak okozta sérelmeknek abba a szférájába lépünk, amely mind Dworkin (mental distress, disgust-harm), mind Post (intrinsic harm), mind pedig Schauer (harm of verbal assault) szerint a szólásszabadság legtalányosabb területe. E szférán belül is ráadásul a leginkább fejtörést okozó esetkört járjuk most körül, amikor is a mentális sérelem nem egyedileg beazonosítható személyt érint, mivel a sérelmes szólás annál elvontabban, tipikusan egy közösségre vonatkozóan fogalmazódik meg. Ez az esetkör a magyar joggyakorlatban a kommunikációs aktusok változatos formáit öleli föl: a sértés akár közvetlenül, akár közvetetten, valamely szimbólum közvetítésével megvalósulhat.

A közösségeket sértő beszéd klasszikus, generális példája a gyalázkodás. Számunkra ez most azért is kiváló kiindulópont, mert az uszítással foglalkozó döntések láncolatából jól láthatóan a gyalázkodó beszéd kérdése az uszítással kéz a kézben jár a szólásszabadság büntetőjogi korlátozásának meghatározásakor. Ez egyszersmind azt is jelenti, hogy a releváns szempontokat ugyanazokból a döntésekböl nyerhetjük, így a fent már hivatkozott határozatok újbóli sorolása helyett most elegendő a gyalázkodásra fókuszáló értelmezések összefoglalására szorítkozni.

A joggyakorlat legmeghatározóbb gondolata e tekintetben mindvégig az, ami miatt a 30/1992. (V. 26.) AB határozat az uszítás alkotmányosságának megállapítása mellett a közösség elleni izgatás másik elkövetési magatartásának a büntetőjogi tiltását már alkotmányellenesnek találta: a gyalázkodás tilalma a társadalmi békét és nyugalmat már elvontan védi, vagyis a büncselekmény egyéni jogok sérelmének veszélye nélkül is megvalósul. Amikor a jogalkotó a gyalázkodás ellen lép fel, akkor abbéli meggyőződése vezérli, hogy a nemzeti és vallási közösségekre nézve sértő kifejezés használata „úgy általában” ellentétes a társadalom kívánatos nyugalmával és az érintett csoportok méltóságával. Az Alkotmánybíróság az elméleti áttekintésünkből ismerős problémát állítja a mérlegelés középpontjába: ha a mérce önmagában a beszéd sértő vagy lealacsonyító jellege, akkor a beavatkozás mércéje - vagy amire még a következő fejezetben visszatérünk: „külső korlátja” - teljes mértékben elbizonytalanodik, és 
egyedül a szavak benső értéke marad meg kapaszkodónak. Ez azonban több mint ingatag kapaszkodó, hiszen mondataink stilisztikai értéke nagyrészt szituációhoz és kulturális szinthez kötött, és folyamatosan változik. ${ }^{58}$

A testület tehát alaphatározatával akként indította útjára a szólásszabadság magyar koncepcióját, hogy alanyi jogok érintettsége vagy a köznyugalom minősített veszélyeztetése nélkül ,a szavainkban bennerejlő sérelem” nem nyújt megfelelő alapot a büntetőjogi korlátozás számára. Amikor a szólás ártalma elvontabb szinten, kevésbé megragadható sérelem formájában jelentkezik, szerepe az alkotmányjogi mérlegelésben radikálisan beszükül. Bár - ahogy arra mindjárt rá is térünk - az évek során bőven születtek döntések, amelyek kihívást jelentenek a doktrínát magyarázni kívánó számára, az értelmezés általános vezérfonala nem változott. A gyülöletbeszéddel foglalkozó döntések sorozatának egyik késői láncszeme, a 95/2008. (VII. 3.) AB határozat abban összegzi az akkorra már csaknem húszéves gyakorlatot, hogy az alapjogi védelem nem tagadható meg pusztán azon az alapon, hogy az elhangzottak mások érdekét, szemléletét, érzékenységét sértik, vagy azok egyes személyekre nézve bántóak, lealacsonyítóak. ${ }^{59} \mathrm{Ez}$ az érv már átvezetne minket a szólással okozott sérelmek értékelésének másik nagy alaptételére, azonban előtte még szembe kell néznünk egy fogós kérdéssel. A többévtizedes alkotmánybírósági gyakorlatban fontos döntéseket találunk, amelyek tagadni látszanak az iménti elveket, és akár tágra is nyithatnák a kaput a közösségeket sértő beszéd büntetése elött. Nézzük meg, így van-e, vagy esetleg találhatók érvek a határozatok doktrínába illesztése mellett.

Mindenekelőtt jelentős kihívás elé állította az 1990-es évek értelmezéseit a szimbolikus beszéd két ominózus kérdésköre, a nemzeti jelképek meggyalázása és az önkényuralmi jelképek használata. Az ügyekben döntő (csak érdekességként: együtt kihirdetett) két alkotmánybírósági határozat magyarázata nem kis fejtörést okoz azok számára, akik a gyülöletbeszéd kapcsán eddig kifejtett alkotmányossági szempontokat fontosnak tartják, de azt állítom, hogy a szavak ártalmával kapcsolatban ismertetett elméleti szempontok nagy segítségünkre lehetnek a lehetséges mértékben koherens narratíva megfogalmazásában.

\footnotetext{
58 30/1992. (V. 26.) AB határozat, Indokolás V.3., ABH 1992, 167, 180.

59 95/2008. (VII. 3.) AB határozat, Indokolás III.2.1., ABH 2008, 782, 786.
} 
A 13/2000. (V. 12.) AB határozat annak a büntető rendelkezésnek az alkotmányosságát bírálta el, amely a magyar nemzeti jelképeket (a himnuszt, a zászlót vagy a címert) sértő, lealacsonyító kifejezés használatát vagy más ilyen cselekmény elkövetését kriminalizálta. A tényállás szövegezését olvasva nem lehet kétséges számunkra, hogy ebben az esetben bizony olyan büntetőjogi tiltással állunk szemben, amely önmagában bizonyos kifejezésformákban bennerejlő - vagyis a közléssel való puszta szembesülésböl fakadó - sérelmekre tekintettel szab határt a szólásszabadságnak. Az is világos, hogy mindezt az ártalmaknak azon az elvontabb szintjén teszi, ahol sem egyéni jogok sérelmére, sem a köznyugalom közvetlen veszélyeztetésére nincs szükség a beavatkozáshoz. Márpedig azt láttuk, hogy az alkotmányos gyakorlat generális szempontjai nem engednek teret az ilyen természetü ártalmakra hivatkozó tiltásnak. Mindezek ellenére amellett érvelek, hogy a tiltást alkotmányosnak ítélő határozat nem írja át a dogmatikai kereteket. Ennek érzékeltetéséhez vegyük kölcsön Robert Post fent bemutatott fogalomkészletét, és tekintsük az Alkotmánybíróságnak a gyalázkodás kapcsán kifejtett általános érveit olyan törekvésnek, amely az asszimilációs, vagyis egyetlen közösség érzékenységét, türésküszöbét, „normáját” védő és mindenki másra ráerőltető jogalkotás letörésére irányul. Ebben a felfogásban a nemzeti jelképek meggyalázásnak tilalma éppen ilyen „asszimilációs szabálynak” tekinthető: a védett jelképekhez való viszonyulás egy bizonyos közösségi elvárását érvényesíti mindenkivel szemben. A helyzet viszonylagos feloldását tehát nem abban látom, hogy tagadható lenne a büntetőjogi rendelkezés „asszimilációs jellege”, hanem e szabály szűkösségében. Vegyük észre, hogy mely körben engedett teret az Alkotmánybíróság egy ilyen természetű szabálynak. A testület érvelése szerint a himnusz, a zászló és a címer az alkotmányban kimerítő jelleggel felsorolt azon szimbólumok, amelyek nem pusztán valamely nemzetiségi közösséghez, hanem a magyar államisághoz, így valamennyi állampolgár politikai közösségéhez kötődnek. Ahogy az indokolás az adott történelmi körülményekre is utalva fogalmaz: „[e]nnél a büntetőjogi szabálynál már nem a nemzetről, nemzetiségről, népről, felekezetről, fajról szóló vélemény kifejtéséről van szó, hanem a függetlenségét csak rövid ideje megélő ország jelképeiről". ${ }^{60}$ Ebben a szük körben a határozat maga ismeri el ,asszimilációs” logikáját: „,[a] demokráciáknak csak egyik lényeges kritériuma a vélemények pluralizmusa. A demokráciákra jellemző

\footnotetext{
${ }^{60}$ 13/2000. (V. 12.) AB határozat, Indokolás IV.3., ABH 2000, 61, 69.
} 
az ország egységét megjelenítő intézmények és szimbólumok léte, amelyek - bár nem kritizálhatatlanok - bizonyos vonatkozásaikban kívül vannak a vélemények alkotmányjogilag védendő pluralizmusán". ${ }^{61}$ Ha a Posttól kölcsönzött logikában tekintünk a nemzeti jelképek megsértésének ügyére, akkor mondhatjuk, hogy az Alkotmánybíróság kizárólag abban a kivételes körben engedett át egy „,asszimilációs szabályt”, ahol a védelem tárgya az államiság alapjaihoz és az állampolgárok lehető legszélesebb, államalkotó közösségéhez kötődő, ráadásul az alkotmányban kimerítően felsorolt szimbolika. A differenciálás lényege érzékelhetővé válik, ha arra mutatunk rá, hogy ugyanez a logika már nem müködne például az egyébként valós és méltó történeti jelentéssel is bíró árpádsávos zászló esetében, mivel annak megítélése oly mértékben megosztja a közösséget, hogy a hozzá kötődő ,asszimiláció” már fontos történelmi, kulturális és morális meggyőződések letörésére szolgálna. ${ }^{62}$

Nem azt állítom tehát, hogy a nemzeti jelképekről hozott határozat érvei összhangban lennének a gyalázkodásra vonatkozó általános értelmezéssel, hanem azt, hogy az attól eltérő asszimilációs logikát az Alkotmánybíróság egy kivételes és szűk körben engedte érvényesülni, ahol az „egységesítő törekvés” - az alkotmányban nevesített szimbólumok révén - a magyar politikai közösség egyetlen tagja számára sem volt kirekesztő, mivel nem egyes kulturális, vallási, nemzetiségi közösségek speciális normáira vagy érzékenységére szabott. Ilyen esetben ráadásul a korlátozás mögött - legalább az alkotmányszövegre építő észszerü vélelmezés vagy politikai reprezentáció szintjén - a társadalom egészének konszenzusa áll, ami az asszimiláció tétjét jelentősen csökkenti. Mindemellett a testület a szabály értelmezését is szigorú korlátok közé terelte annak az indokolásban foglalt alkotmányossági követelménynek a megfogalmazásával, amely szerint a nemzeti jelképeket illető negatív tartalmú vélemények, a jelképek történetére, értékére, közjogi jelentőségére vonatkozó tudományos nézetek, müvészi kifejezések, illetőleg kritikák hangoztatása, esetleg megváltoztatásukat vagy eltörlésüket célzó javaslatok kifejezésre juttatása, értelemszerüen nem eshet büntetőjogi szankcionálás alá, hanem része a véleménynyilvánítás alkotmányos szabadságának. ${ }^{63}$

\footnotetext{
${ }^{61}$ Uo., Indokolás IV.4., ABH 2000, 69.

${ }^{62}$ TóTH Gábor Attila: Túl a szövegen. Értekezés a magyar alkotmányról. Budapest, Osiris, 2009. 223224.

${ }_{63}^{13 / 2000 . ~(V . ~ 12 .) ~ A B ~ h a t a ́ r o z a t, ~ I n d o k o l a ́ s ~ I V .6 ., ~ A B H ~ 2000, ~} 70$.
} 
Hasonló logikában, vagyis a szóban forgó sérelem helyes azonosításával találhatjuk meg az önkényuralmi jelképek használatának büntetőjogi tiltását elbíráló 14/2000. ( $V$. 12.) $A B$ határozat helyét is. A vizsgált szabály a náci-nyilas és a kommunista diktatúrák legfontosabb szimbólumainak (horogkereszt, SS-jelvény, nyilaskereszt, sarló-kalapács és ötágú vöröscsillag) terjesztését és nyilvános használatát büntette. Értékelésünket ez esetben is annak elismerésével kell kezdenünk, hogy ez a szabály szintén a szimbolikus beszéd egyes megnyilvánulásainak puszta meghallásából eredő „bennerejlő ártalmakra” reagál, anélkül, hogy a gyülöletkeltő vagy felforgató (például rémhírt terjesztő) beszéd általános mércéit - egyéni jogok belátható fenyegetettségét vagy a köznyugalom közvetlen veszélyeztetését - alkalmazná. Azt gondolom, ez a határozat is akkor illeszthető csak be a lehetséges mértékig koherens módon a doktrínába, ha megpróbálunk az indokolásban foglaltaknál nagyobb rendet tenni abban a tekintetben, hogy jelen esetben mire, milyen sérelem kiküszöbölésére vonatkozik a büntetőjogi védelem.

A testület érvelésének fősodra nem sokat segít nekünk ebben, mivel az éppen hogy megmarad abban a logikában, amelyben a problémák fölmerülnek: a sérelmet a köznyugalom zavarásában és egyes közösségek (a demokrácia mellett elkötelezettek) megsértésében látja. Bár a határozat maga is érzékeli a dogmatikai feszültséget, nem tünik meggyőzőnek érvelése, mely szerint ,[j]óllehet, hogy a törvény által védett értékek - mint a köznyugalom és a demokrácia értékei mellett elkötelezett közösségek méltósága - megsértésének büntetőjogi szankcionálása külön-külön esetleg más alkotmányossági elbírálás illetve értékelés alá eshetne; mivel azonban az önkényuralmi jelképek használata e két értéket együttesen, egyszerre sérti, egymást felerősítő, kumulatív hatásuk jelentkezik, és ehhez kapcsolódik a közvetlen történelmi előzményeknek még ma is érvényesülő hatása" ${ }^{64}$ Aligha tévedünk ugyanis abban, hogy ez az az érv, amely a közösségeket sértő szólásnál minden esetben bevethető lenne, kiüresítve ezzel az általános védelmi mércéket: a társadalmi csoportokat érő gyalázkodás az elvontságnak ezen a szintjén minden esetben összefüggésbe hozható a köznyugalommal. Ezzel szemben nekünk egyedi érvre van szükségünk a feszültség feloldásához.

Ezt az egyedi érvet annak a megjegyzésnek a kibontásából nyerhetjük, amely megjelenik ugyan a határozat indokolásában, de semmilyen értékelhető hangsúlyt nem

\footnotetext{
${ }^{64}$ 14/2000. (V. 12.) AB határozat, Indokolás IV.5., ABH 2000, 83, 99.
} 
kap az alkotmányjogi érvelésben: olyan szimbólumok használatának korlátozásáról beszélünk, amelyek a demokratikus jogállami berendezkedéssel teljes mértékben összeegyeztethetetlen, a hatalom erőszakos megszerzésén és kizárólagos birtoklásán alapuló politikai diktatúrák jelképei. Ezek a szimbólumok ezáltal olyan politikai törekvéseket jelképeznek, amelyeket az alkotmány tilt és mindenki kötelességévé teszi a velük szembeni fellépést. ${ }^{65} \mathrm{Az}$ alkotmánybírósági határozat okozta dogmatikai feszültséget akkor oldhatjuk fel leginkább, ha az önkényuralmi jelképek tiltására nem a köznyugalmat vagy közösségeket védő szabályként tekintünk, hanem olyan rendelkezésként, amely a demokratikus állam és hatalomgyakorlás legmeghatározóbb alkotmányos értékeit és alapelveit védi. Alkotmányjogi szemmel nézve más természetű tehát az ártalom, amire a büntetőjog reagálni próbál: nem bizonyos sértő szavak meghallása okozta lelki fájdalom önmagában, hanem legféltettebb alkotmányos eszméink aláásása. Ha a tiltott szimbolikus beszédet a demokratikus pluralizmus, a kisebbségek védelme, a hatalom eröszakos megszerzésének és kizárólagos birtoklásának tilalma, illetve az erőszakos konfliktusmegoldásról való lemondás nyílt tagadásaként azonosítjuk, akkor érzékelhetőbbé válhat az itt alkalmazott mérce specialitása. A szóban forgó kérdés ilyetén felfogása tehát nem abban segít, hogy meglássuk, a határozat miként illeszthető be a gyalázkodás általános szempontjai közé, hanem éppen abban, hogy észrevegyük egyediségét és kivételességét. Nem vitatható azonban a velünk azonos logikában érvelő párhuzamos indokolás igazsága, hogy ezt az értelmezést az Alkotmánybíróságnak alkotmányos követelményben kellett volna megerösítenie, e helyett pedig még csak nem is erre, hanem a köznyugalomra és a méltóságra utaló álláspontra helyezkedett. ${ }^{66}$

A határozatnak ez a mulasztása nem maradt következmények nélkül. Az önkényuralmi jelképek tiltásának ügye az Alaptörvény hatálybalépését követően is az Alkotmánybíróság elé került, és a testület a korábbi határozata óta felmerült szempontokra, mindenekelőtt az Emberi Jogok Európai Bíróságának döntéseire, illetve a hazai joggyakorlat ellentmondásaira tekintettel ismét érdemi döntést hozott. A 4/2013. (II. 21.) AB határozat helyesen tekintette a strasbourgi bíróság gyakorlatát arra való felhívásként, hogy a magyar szabályozást szükebbre kell vonni. A Vajnai kontra Magyarország ügyben ${ }^{67}$ az EJEB rámutatott arra, hogy a vöröscsillag többes

\footnotetext{
${ }^{65}$ Uo., Indokolás IV.3., ABH 2000, 96.

${ }^{66}$ Holló András párhuzamos indokolása

${ }^{67}$ Vajnai kontra Magyarország (33629/06), 2008. július 8-i ítélet
} 
jelentésére figyelemmel olyan korlátozás fogadható csak el, amely félreérthetetlenül az önkényuralmi jelképpel való azonosulásra vonatkozik. A szimbólumok használatának disztingvált megközelítésére szólított fel továbbá a bíróság a Fáber kontra Magyarország ügyben is az árpádsávos zászló kapcsán. ${ }^{68} \mathrm{Az}$ Alkotmánybíróság emellett a magyar bírósági gyakorlat ellentmondásainak elemzésével is arra jutott, hogy a büntetőjogi szabályozásnak - szigorúbb alkotmányossági követelményeknek megfelelve - egyértelmübb iránymutatást kell adnia. A testület erre tekintettel a korábbi rendelkezést pro futuro hatállyal megsemmisítette ugyan, de indokolásával mégsem járult hozzá a szólásszabadság doktrínájának tisztázásához, mivel döntését a jogállami büntetőjog alkotmányos kívánalmaira, nem pedig a véleményszabadság szempontjaira alapozta. A véleménynyilvánítás szabadsága számára ismét egy párhuzamos indokolás igyekezett kijelölni a szóban forgó tilalom helyét, rámutatva arra, hogy a büncselekmény védett jogi tárgya valójában nem a köznyugalom, hanem az alkotmányos állami berendezkedés, így csak azok a közlések lennének tilthatók, amelyek a demokratikus alapértékekkel ellentétes nézeteket fejeznek ki és ezen alapértékek társadalmi gyengítését célozzák. ${ }^{69}$

Az alkotmánybírósági határozat többségi indokolásának újabb mulasztása ismét nem maradt következmények nélkül: a törvényhozó a büncselekményt a köznyugalomra és a közösségek méltóságára alapozott érvek mentén szabályozta újra. $^{70} \mathrm{Az}$ önkényuralmi jelképek tiltásának beillesztése a szólásszabadság doktrínájába így továbbra is tudományos elemzés feladata, remélve, hogy előbb vagy utóbb a joggyakorlat is felismeri e tisztázás szükségességét. ${ }^{71}$

A tisztázás szükségét ráadásul tovább növelte, hogy a törvényhozó időközben újabb tényállást iktatott a büntető törvénykönyvbe, és a nemzetiszocialista vagy kommunista

\footnotetext{
${ }^{68}$ Fáber kontra Magyarország (40721/08), 2012. július 24-i ítélet

${ }^{69}$ Bragyova András párhuzamos indokolása erre tekintettel a tényállást politikai bűncselekményként fogja föl; Indokolás [84]

70 Btk. 335. § Aki horogkeresztet, SS-jelvényt, nyilaskeresztet, sarló-kalapácsot, ötágú vöröscsillagot vagy ezeket ábrázoló jelképet a köznyugalom megzavarására alkalmas - különösen az önkényuralmi rendszerek áldozatainak emberi méltóságát vagy kegyeleti jogát sértő - módon $a$ ) terjeszt, $b$ ) nagy nyilvánosság elött használ, vagy c) közszemlére tesz, ha súlyosabb büncselekmény nem valósul meg, vétség miatt elzárással büntetendő.

${ }^{71}$ A továbbra is fennálló jogalkotási hiátusok miatti jogalkalmazási nehézségekre figyelmeztet Tóth J. Zoltán is. TóTH J. Zoltán: Az önkényuralmi jelképek használata mint a véleménynyilvánitási szabadság korlátja? (A 4/2013. AB határozat elözményei, indokai és következményei, valamint az új Btk.szabályozás pozitívumai és fogyatékosságai). Jogelméleti Szemle 2013/2. 196.
} 
diktatúrák bűneinek tagadását is pönalizálta. ${ }^{72} \mathrm{~A}$ fentiek után e helyütt már csak elég visszautalnunk az imént jelzett kihívásokra, mivel a holokauszttagadás problematikája osztozik a jelképes döntések feszültségeiben - olyannyira, hogy ezek a feszültségek még az eddigieknél is erősebben jelentkeznek. Különösen az önkényuralmi szimbólumok tiltása kapcsán elmondottakhoz érdemes ismét nyúlnunk: a diktatúrák büneinek tagadása csak akkor kap értelmet a gyalázkodást egyébként toleráló doktrína számára, ha nem közösségeket sértő vagy köznyugalmat távolról érintő beszédként, hanem a demokratikus jogállami berendezkedést semmibe vevő véleménynyilvánításként definiáljuk. Ez a definíciós törekvés azonban a szükségesnél ismét lényegesen kevesebb fogódzót kapott a tényállást felülvizsgáló 16/2013. (VI. 20.) $A B$ határozattól. Az indokolás az önkényuralmi jelképek kapcsán kifejtett alkotmánybírósági érveket felhívva elsődlegesen az áldozatok és a demokrácia mellett elkötelezettek közössége, valamint a közfelháborodással megzavart köznyugalom védelmének szükségességével érvel. ${ }^{73} \mathrm{~A}$ mi törekvésünk számára mindössze az a rövidke megjegyzés marad kapaszkodóként, mely szerint a tényállást a demokratikus állami működés alapfeltételét jelentő legfontosabb jogállami értékek melletti elkötelezettség is indokolja. ${ }^{74}$

Összegezve a közösségeket sértő beszéd körében eddig folytatott vizsgálódásunkat: az alkotmánybírósági judikatúra legfajsúlyosabb döntéseinek láncolata alapján az állapítható meg, hogy a szólásszabadság magyar doktrínájának generális iránymutatása szerint az egyéni jogokat nem fenyegető és a köznyugalom minősített veszélyével sem járó közlések körében a szavak meghallásából fakadó lelki fájdalmak (,bennerejlő bántalmak”) nem teremtenek jogalapot a büntetőjogi beavatkozásra. A főszabállyal feszültségbe kerülő határozatok rendszerbeli helyét pedig akkor találhatjuk meg viszonylagos sikerrel, ha a bennük vizsgált sérelmek megkülönböztetésével sajátos és kivételes tesztekként tekintünk rájuk, amelyek az érintett ártalmak egyedisége miatt nem terjeszthetők ki egykönnyen további esetekre.

Erre utalnak az alkotmányos értelmezések között fellelhető más olyan elemek is, amelyek bár a közösséget sértő közlés meghallásából fakadó ártalmakra materiális

\footnotetext{
72 Btk. 333. § Aki nagy nyilvánosság előtt a nemzetiszocialista vagy kommunista rendszerek által elkövetett népirtás vagy más, emberiesség elleni cselekmények tényét tagadja, kétségbe vonja, jelentéktelen színben tünteti fel, vagy azokat igazolni törekszik, büntett miatt három évig terjedő szabadságvesztéssel büntetendő.

73 16/2013. (VI. 20.) AB határozat, Indokolás [50] és [52]

${ }^{74}$ Uo., Indokolás [51]
} 
következmények értékelése nélkül reagálnak, a jogi korlátozást további speciális körülményekre tekintettel tartják elfogadhatónak. Bizonyos körben még a gyülöletbeszéd általános büntetőjogi mércéjét határozottan az uszításhoz kötő 95/2008. (VII. 3.) $A B$ határozat is lát lehetőséget gyalázkodó közlések kriminalizálására. Eszerint ha az elkövető oly módon nyilvánítja ki szélsőséges politikai meggyőződését, hogy a sértett csoporthoz tartozók kénytelenek megfélemlítve végighallgatni, és nincs módjuk kitérni a szólás elől, akkor a véleménynyilvánítás korlátozható. ${ }^{75} \mathrm{~A}$ „,foglyul ejtett közönség” szituációjában a gyalázkodó közlés végighallgatásához nem (feltétlenül) kötődik további erőszakos tett vagy annak veszélye, azonban a helyzet sajátossága révén a lelki megrázkódtatás, megfélemlítés a büntetőjog számára értékelhetővé válik. Ilyen körülmények között egyrészt a célba vett sértetti kör konkretizálhatóbb, másrészt a megszólaló megfélemlítő szándéka is nyilvánvalóbb, harmadrészt a kitérés lehetőségének elvesztésével az érzelmi fájdalom is jobban megragadható. Mindezekre tekintettel a „foglyul ejtett közönség” szituációjában az egyébként az uszítás szintjét el nem érő gyülöletbeszéd mégis az egyéni jogsérelmek szintjén kerülhet értékelésre.

Nem látni egyelőre a pontos gyakorlati müködését annak a viszonylag újabb jogi konstrukciónak, amely a közösséget sértő egyes véleményekkel szemben - a sérelem „átsugárzása" folytán - a közösséghez tartozóknak enged polgári jogi fellépést. ${ }^{76} \mathrm{~A}$ jogintézményt nemcsak a törvényhozó, hanem az alkotmánymódosító hatalom is fontosnak tartotta, és az Alaptörvény negyedik módosításával a IX. cikk (5) bekezdésében alkotmányos alapot teremtett számára. ${ }^{77}$ Azt állítom ugyanakkor, hogy ha a szólásszabadság doktrínájának koherenciáját meg kívánjuk őrizni, akkor a helyes értelmezés kidolgozásához - összhangban az Alkotmánybíróság iránymutatásával,

\footnotetext{
75 95/2008. (VII. 3.) AB határozat, Indokolás III.3.4., ABH 2008, 782, 789.

${ }^{76}$ Ptk. 2:54.§ (5) A közösség bármely tagja jogosult a személyisége lényeges vonásának minősülő, a magyar nemzethez, illetve valamely nemzeti, etnikai, faji vagy vallási közösséghez tartozásával összefüggésben a közösséget nagy nyilvánosság elött súlyosan sértő vagy kifejezésmódjában indokolatlanul bántó jogsérelem esetén a jogsértés megtörténtétől számított harmincnapos jogvesztő határidőn belül személyiségi jogát érvényesíteni. A közösség bármely tagja a jogsértéssel elért vagyoni előny átengedésének kivételével a személyiségi jogok megsértésének valamennyi szankcióját érvényesítheti.

77 Alaptörvény IX. cikk (5) A véleménynyilvánítás szabadságának a gyakorlása nem irányulhat a magyar nemzet, a nemzeti, etnikai, faji vagy vallási közösségek méltóságának a megsértésére. Az ilyen közösséghez tartozó személyek - törvényben meghatározottak szerint - jogosultak a közösséget sértő véleménynyilvánítás ellen, emberi méltóságuk megsértése miatt igényeiket bíróság előtt érvényesíteni.
} 
mely szerint az Alaptörvény nem jelent törést a véleményszabadság értelmezésében ${ }^{78}$ érdemes figyelemmel lennünk a korábbi gyakorlatra is.

A jogintézménnyel kapcsolatos alkotmányossági szempontokat kifejtő 96/2008. (VII. 3.) AB határozat értelmezéséhez megint csak kitünő megközelítésnek mutatkozik az ártalmak szétválasztásának módszere. Ez annál is inkább így van, mivel az Alkotmánybíróság az indokolásban központi tétellé tette a sérelmi szintek elkülönítését, amelyet a korábbi „hagyományos” megfogalmazás idézésén túl további magyarázó mondatokkal is megerősített: „[a]z Alkotmánybíróság gyakorlata következetes abban, hogy a véleményszabadság korlátozhatóságát és annak mértékét a jogsértő magatartás és az okozott alanyi jogsérelem közötti viszony intenzitása határozza meg. Alanyi jogban okozott sérelem a kommunikációs anyajog súlyosabb korlátozását indokolja, ugyanakkor az alanyi jog közvetett sérelme, avagy ha a megsértett védett jogi tárgy nem hozható összefüggésbe alanyi jog sérelmével, a véleménynyilvánítás szabadsága kevéssé vagy egyáltalán nem korlátozható."79 Ezek után nem lehet meglepő, hogy a határozat egyfelől éppen hogy megerősíti a korábbi generális iránymutatást, mely szerint a közösségekre vonatkozó általánosító beszéddel kiváltott elvont sérelem nem ad alapot a szankciók alkalmazására. Másfelől ugyanakkor kétségtelen, hogy az „átsugárzásra” alapított jogi konstrukciót bizonyos körben alkotmányosnak tekinti, és ezzel elismeri, hogy az általánosító beszéd adott esetben önmagában is egyéni jogokat sérthet. Mégis: fontos észrevennünk, hogy az Alkotmánybíróság nem a sérelmi szintek eltérő súlyának tételét vonta kétségbe, hanem azt állapította meg, hogy speciális körülmények között a közösséget gyalázó közlés individuális jogsérelemre vezethet.

Kulcskérdéssé ezek után az válik, hogy pontosan mely körben nyílik lehetőség e megoldás alkalmazására, ami abból is jól látható, hogy a testület az előtte fekvő szabályozást alkotmányellenesnek találta. A határozat összetett, több szálon futó érvelése az aránytalanság eltérő, egymást erősítő indokait azonosítja, mi azonban e helyütt csupán a sérelem körében releváns értelmezésekre fókuszálunk. Nyilvánvaló ugyanis, hogy az általánosító beszéd ártalmasságának tolerálásáról szóló korábbi értelmezési tételek megerősítése után az Alkotmánybíróságnak mondania kellett valamit arról, milyen szempontok mentén állapítható meg a közösségekre vonatkozó

\footnotetext{
${ }^{78}$ Vö. 7/2014. (III. 7.) AB határozat

${ }^{79}$ 96/2008. (VII. 3.) AB határozat, Indokolás III.2.3., ABH 2008, 816, 823.
} 
sérelem ,átsugárzása” és egyéni személyiségi jogi sérelemben való konkretizálódása. Az indokolás erre vonatkozó mondatai arra utalnak, hogy ez kivételesen szük körben képzelhető csak el, amikor (1) a véleménynyilvánítás a közösség egészére vonatkoztatott, (2) a közösség tagjainak megkérdőjelezhetetlen, lényeges tulajdonságával áll összefüggésben, és (3) akár a közösség létét is megkérdőjelezően szélsőséges. ${ }^{80}$ Kizárólag ez az az esetkör, amikor az általánosító beszéd a közösséghez tartozók bármelyikére vonatkoztatható, így az alanyi jogokat érintő hatása kellően intenzív ahhoz, hogy az egyéni jogsérelmek szintjére léphessünk. Meggyőződésem, hogy ennek az értelmezésnek a komolyan vétele a jogintézmény alkalmazását az emberi méltóság korlátozhatatlan magját érintő esetekre szorítja, amikor a véleményt nyilvánító mások emberi minőségét adott közösséghez tartozásuk miatt alapjaiban tagadja, emberi mivoltuk legbensőbb lényegét támadva. ${ }^{81}$

Nem állítom ugyanakkor, hogy a közösségeket sértő beszéd körében az Alaptörvény negyedik módosításával kapcsolatban fölmerült értelmezési kihívások végére értünk volna. Akkor sem, ha e tekintetben egyébként az a 7/2014. (III. 7.) $A B$ határozat tekinthető mérföldkőnek, amelyre eddig bizton támaszkodhattunk, amikor a doktrína koherenciájának megőrzése a korábbi tételek megtartását igényelte. Az Alaptörvény IX. cikk (4) bekezdésének értelmezésekor az Alkotmánybíróság úgy ítélte meg, hogy az új szövegrész nem írta fölül a szólásszabadság korábbi felfogását, és „nem rontotta le” a korábbi tételeket. A testület abból indult ki, hogy a szólásszabadságot kibontó értelmezésének kezdettől fogva sarokköve volt, hogy mások emberi méltósága a véleményszabadság korlátja lehet. ${ }^{82}$ Eszerint az Alaptörvény IX. cikk (4) bekezdése szövegszerủen is egyértelmüvé tette azt, ami az emberi méltóság alkotmányos helyéből egyenesen következik, ti. hogy az még a kitüntetett szereppel bíró véleményszabadságnak is korlátja lehet. Az alapjogok korlátozásának követelményeiből következően ugyanakkor az alkotmányossági kérdés ez esetben is mindig az, hogy pontosan mely esetben és meddig kell a szólásszabadságnak engednie, vagyis az emberi méltóság védelmét szolgáló korlátozás mikor minősül szükségesnek és arányosnak. Az Alkotmánybíróság szerint nyilvánvaló

\footnotetext{
${ }^{80}$ Uo., Indokolás III.3., ABH 2000, 824. Az indokolás a korábbi gyakorlatra utalva később a vallási meggyőződést vagy nemzetiségi identitást nevesítette a lényegi vonás példáiként (IV.1.1.).

$81 \mathrm{Az}$ emberi méltóság legbensőbb szférájáról, az emberi mivolt lényegi magjáról mint a szólásszabadság korlátozásának speciális mércéjéről elsőként lásd a 7/2014. (III. 7.) AB határozatot, Indokolás [24], [43], [60], [62].

${ }^{82}$ 30/1992. (V. 26.) AB határozat, Indokolás IV.2., ABH 1992, 167, 174.
} 
ugyanis, hogy az adott szabályozás emberi méltósággal való bármilyen összefüggése önmagában nem igazolhatja a szólásszabadság korlátozását, ellenkező esetben a szólásszabadság tartalma kiüresedne, mivel az emberi méltósággal, illetve az abból fakadó jogokkal a jogszabályi rendelkezések rendkívül széles köre áll közelebbi vagy távolabbi kapcsolatban. ${ }^{83}$

A dolgozat első fejezetében is kitértünk már ugyanakkor arra, hogy eltérő megközelítés látszik megjelenni egy másik, a közösségeket sértő beszéd kérdését speciális körülmények között, a parlamenti szólások megítélése kapcsán vizsgáló döntésben. A testületnek országgyülési képviselők alkotmányjogi panasza alapján arról kellett döntenie, milyen alkotmányossági szempontok szerint kell megítélni a parlamenti fegyelmi jognak a felszólalások szankcionálására lehetőséget adó rendelkezéseit. A 3206/2013. (XI. 18.) AB határozat indokolatlan egyszerüséggel intézte el a valamely személyt, csoportot - különösen valamely nemzeti, etnikai, faji vagy vallási közösséget - kirívóan sértő kifejezések használatát is. Érvelése szerint tekintettel arra, hogy az Alaptörvény IX. cikk (4)-(5) bekezdése alapján a véleménynyilvánítás alaptörvényi védelme eleve nem terjed ki ezekre az esetekre, ezeknél a véleményszabadság sérelme fel sem merülhet. A döntés indokolása ezen a ponton ugyanis azon az értelmezésen alapul, hogy az Alaptörvény IX. cikk (4) és (5) bekezdése a szólásszabadság hatályát szűkíti le, kirekesztve abból a mások emberi méltóságát vagy a közösségek méltóságát sértő beszédet. Eszerint az olyan megszólalások alkotmányos megítélése körében, amelyek valakire vagy valakikre sértő tartalmat hordoznak, nincs is helye a szólásszabadság-szempontok mérlegelésének - ahogy ez a mérlegelés hiányzik is az Alkotmánybíróság döntéséből. És noha a konkrét esetben „kirívóan sértő” kifejezésekről szólt a vizsgált rendelkezés, ha az alaptörvényi mondatoknak ilyen értelmet adunk, akkor valójában bármely sértés esetén hasonlóan járhatunk el, hiszen az alkotmányszöveg nem kvalifikálja a sértegetést. A sértő beszéd így a törvényi szabályozás szabad prédájává válik, amelynek alkotmányossági vizsgálata körében fel sem vetődhet, hogy a jogalkotó a szólásszabadságot arányosan korlátozó megoldást választott-e.

Reményeim szerint a dolgozat eddigi elemzéseit követően belátható, hogy ha az Alkotmánybíróság e határozat érvei mentén haladna tovább (amit optimista módon egyelőre valószínűtlennek tartok), az nemcsak a korábbi alkotmányos tételek átírását

${ }^{83}$ 7/2014. (III. 7.) AB határozat, Indokolás [24] és [43]. 
jelentené, hanem feloldhatatlannak tünő ellentmondást hozna a szólásszabadság doktrínájába.

\subsection{A sérelem értékelésének alapszemlélete: a szólás joga}

Jelen fejezetben mind ez idáig a szavainkkal okozható sérelmekre fókuszálva azt jártuk körül, hogy milyen szempontjaink vannak a beszéd ártalmainak megragadásához és értékeléséhez. Mindenekelőtt elismertük, hogy közléseink sérelmesek tudnak lenni, és rámutattunk arra, hogy a különféle bántalmak elkülönítésével és helyes azonosításával meghatározó hangsúlyokat tudunk tisztába tenni a szólásszabadság doktrínájában. A magyar gyakorlatot vizsgálva az értékelés kulcsfontosságú tételére leltünk, mely a sérelmek három szintjét elkülönítve az alanyi joghoz való kötődés erejétől teszi függővé a mérlegelésben elfoglalt helyüket. A jogi fellépésre a legnagyobb lehetőséget nyújtó individuális jogsérelmek kérdését eddig csak érintettük, mivel annak példáján már inkább a szólások ártalmainak értékelését alapjaiban meghatározó másik tézisünket szemléltetjük.

Ez az a tézis, amely szavaink és a velük okozott sérelmek viszonyának alkotmányossági sarokpontjait a helyükre teszi: a szólásszabadság nem a kifejezések ártalmatlan voltára hivatkozva oltalmazza azokat, hanem a bántalmak ellenére is, amelyeket okozhatnak, mivel csak így biztosíthatja a demokrácia müködéséhez elengedhetetlenül szükséges jogot a szólásra. A közlések számára éppen azért kell lekerítenünk egy beavatkozásoktól mentes területet alkotmányos céljaink elérésére, mert ha a hétköznapi értelemben vett sokféle fájdalomból indulnánk ki, amelyet kiválthatnak, akkor teljesen értelmetlen lenne szabad kinyilvánításukról beszélni. Minderre tekintettel a sérelmek helyét és jelentőségét az előttünk fekvő ügyben mindig annak figyelembevételével kell kijelölni, hogy a szólásszabadság alkotmányos joga érvényesülni tudjon. Ez nem érinti a szavak különféle ártalmairól mondott elméleti megfontolásokat és gyakorlati szempontokat, de megfordítja a mérlegelést végző alapállását: a szólásszabadság doktrínája a bántalmakat mindig azon a szemüvegen keresztül nézi, hogy a demokratikus alkotmányosság számára kitüntetett jelentőségü véleménynyilvánítás joga betölthesse rendeltetését. 
Ez az alaptétel természetesen a joggyakorlat egészét végigkíséri, így a gyülöletbeszéd példáira is visszatérünk majd még röviden, mindenekelött azonban a szólásszabadság és a személyiségvédelem problémakörén érdemes rámutatnunk a jelentőségére. Itt jelentkezhet ugyanis a legkevesebb bizonytalanság az „ártalom oldalán": a konkrét személyeket érő sérelmek a legkevésbé spekulatívak, és - mint láttuk - számukra a szólásszabadság doktrínája is fokozott figyelmet szentel. Éppen ezért válik a legbeszédesebb példává, hogy a következetes joggyakorlat a sérelmek jogi orvoslásának még ebben a körben is megálljt parancsol, ha az a véleménynyilvánítás jogának érvényesülését ellehetetlenítené vagy jelentősen megnehezítené. Minél erősebb érvek szólnak a közlési szabadság akadálytalan gyakorlása mellett, a jogi értékelésben annál kisebb a súlyuk a szólással okozott bántalmaknak.

Az előző fejezetben láttuk, hogy a véleményszabadság melletti érvek és védelmi igények a közügyek vitájához kötődően erősödnek föl - ezzel összhangban az Alkotmánybíróság a személyiségvédelem követelményeit is ebben a körben sorolta hátrébb a szólásszabadság alkotmányos szerepének betöltése érdekében. Első ízben a 36/1994. (VI. 24.) AB határozat ütköztette egymással a közügyek vitatásához, illetve a közszereplők személyiségi jogainak (emberi méltóságának, becsületének, illetve jó hírnevének) büntetőjogi védelméhez tartozó alkotmányossági szempontokat. Bár egy későbbi releváns döntésben - a 7/2014. (III. 7.) AB határozatban - találunk majd megjegyzést, ami némiképp árnyalja a képet, azért egyértelmü marad, hogy az Alkotmánybíróság a közvita kereszttüzében állókra nem azért szabott ki magasabb türési küszöböt, mintha az ő becsületükön vagy jó hírnevükön ne eshetne csorba a politikai csatározások közben. Épp ellenkezőleg: a testület a határozat indokolásában mindvégig következetesen hangsúlyozza, hogy a sajátos mércéket olyan megnyilatkozásokra, „kellemetlen, éles, esetleg igazságtalan” támadásokra és tényállításokra is tekintettel alakította ki, amelyek elvileg alkalmasak lehetnek a közéleti szereplök becsületének csorbítására. ${ }^{84} \mathrm{~A}$ közhatalom gyakorlásában résztvevő személyek esetében tehát nem azért szorul háttérbe a személyiségvédelem, mert az ö esetükben eleve ne lehetne megalapozottan érvelni konkrét alanyi jogi sérelem mellett, hanem azért, mert „a demokratikus társadalom létezésének és fejlődésének nélkülözhetetlen eleme a közügyek vitatása”, amely minél kötetlenebb bírálatukat

\footnotetext{
${ }^{84}$ 36/1994. (VI. 24.) AB határozat, Indokolás III.1., ABH 1994, 219, 229.
} 
igényli. Nem arról van szó, hogy ne lehetne bántalmat azonosítani az egyik oldalon, hanem arról, hogy a másik oldalon a közhatalmat gyakorlók és a közéletet alakítók bírálhatóságához kötődő „kiemelkedő alkotmányos érdek” érvényesülése forog kockán. A szólásszabadság joga ebben a legfontosabb körben csakis akkor töltheti be rendeltetését, ha „a polgárok bizonytalanság, megalkuvás, félelem nélkül” vesznek részt a közügyek vitájában, és ez az alkotmányos nézőpont gyökeresen más megvilágításba helyezi az érintettek esetleges sérelmeit. ${ }^{85}$ A mérlegelést mindenekelőtt a véleménynyilvánítás szabadságának tartalma határozza meg: ahol e jog a demokratikus társadalmi vita kibontakozását szolgálja, ott gyakorlása elé a latban egyébként sokat nyomó egyéni sérelmek sem gördíthetnek akadályt. Dogmatikai vitathatósága ellenére is roppant kifejező a határozat megállapítása, mely szerint e körben a személyiségvédelem büntetőjogi eszközei „azokban az esetekben alkalmazhatók, amelyekre a véleménynyilvánítás szabadsága már nem terjed ki.” A demokratikus közhatalmat gyakorlók kritikája ugyanakkor a társadalom tagjainak még akkor is alapvető alanyi joga marad, ha egyébként sérelmet okoz, vagyis becsületsértő megnyilvánulásban ölt testet. ${ }^{86}$

A szólásszabadság magyar doktrínája számára döntő jelentőséggel bír, hogy a mérlegelésnek ezt a szemléletét az Alkotmánybíróság az Alaptörvény, sőt annak negyedik módosításának hatálybalépését követően is megerösítette. A 7/2014. (III. 7.) $A B$ határozat értelmében a véleménynyilvánítás jogának gyakorlata a jövőben sem teheti a középpontba önmagában a szólással okozott sérelmet, hanem figyelmét a demokratikus társadalom számára nélkülözhetetlen közlési szabadság érvényesülésére kell fordítania. A szólásszabadság alkotmányos ereje a védelem bensőbb körében a más esetekben egyébként releváns bántalmak jogi orvoslásának sem enged teret. A jog-központú megközelítést ez a határozat nemcsak megerösítette az addig már kifejtett formában és körben, hanem több fontos megállapítással a doktrína generális módszerévé tette. Egyrészt a korábban büntetőjogi környezetben kifejtett tételeket kiemelte ebböl a kontextusból és szélesebb körben deklarálta érvényüket. A közügyeket vitató megszólalásokat ugyanis értelemszerüen nem csupán a büntetőjogi beavatkozásokkal szemben kell biztosítani, hanem - az élénk demokratikus diskurzus védelmében - más jogágak fellépésétől is óvni kell. Ezzel összhangban szögezte le a határozat, hogy a személyes sérelmeknek a szólásszabadság érvényesülése érdekében

\footnotetext{
${ }^{85}$ Uo., Indokolás III.2., ABH 1994, 230.

${ }^{86}$ Uo., Indokolás III.2., ABH 1994, 230.
} 
történő háttérbe szorulása a büntetőjogi felelősségre vonáson túl a polgári jogi jogkövetkezmények tekintetében is irányadó, mivel a közvitában való részvételtől korántsem csak a kriminális büntetések kockázata tarthat vissza, hanem a civiljogi szankciók is. ${ }^{87}$ Másrészt az is világossá vált, hogy a szólásszabadság átütő ereje nem annak tudható be, hogy a közhatalmat gyakorlók és a politikusok személyisége valamely oknál fogva kisebb értékkel bírna a számunkra. A szemlélet alapja nem ez, hanem a közügyek vitatásához kötődő alkotmányos jog biztosítása, amiből egyenesen következik, hogy a személyiségvédelem korlátozottsága nemcsak a hivatásos közszereplők esetében irányadó, hanem a közvita valamennyi érintettjére vonatkozik. „[M]ivel a politikai véleményszabadság fókuszában elsősorban maguk a közügyek, nem pedig a közszereplők állnak, a közügyekre vonatkozó szólások mindegyike fokozott védelem alá tartozik, és ezáltal korlátozza az általa érintettek személyiségi jogainak védelmét". ${ }^{88}$

Más kérdés, hogy a szólásszabadság melletti, illetve a személyiségvédelem korlátozottsága melletti érvek a közhatalmat gyakorló személyek és a közszereplö politikusok esetében a legerösebbek. Ebben a körben a határozat indokolása odáig merészkedik, hogy egyes megfontolásainak továbbgondolásával akár arra a következtetésre is juthatunk, hogy a hivatásos politikaformálókkal kapcsolatban magának a sérelemnek, vagyis a becsület vagy jó hírnév csorbulásának a léte is megkérdőjelezhető. Legalábbis ebbe az irányba mutat az a megjegyzés, mely szerint „az ő esetükben a személyüket ért bírálatot és minősítést a társadalmi nyilvánosság eleve másként, a demokratikus vita szükségszerü részeként, jellemzően a különböző politikai érdekek mentén értelmezendő megnyilvánulásként kezeli. Magyarországon az elmúlt időszakban kialakultak a plurális politikai nyilvánosság müködésének sajátosságai, amelyek között a közéleti viták során elhangzottakat a társadalom kellő körültekintéssel tudja értékelni." 89 Összességében a jog-központú megközelítés krédójának is beillik a határozat megállapítása, mely szerint a közéleti megnyilatkozások a társadalom tagjainak olyan alapvető joga, amely a demokrácia lényegi eleme, ezért az ilyen véleménynyilvánítás főszabály szerint polgári jogi felelősségre vonásnak sem lehet alapja. ${ }^{90}$

\footnotetext{
87 7/2014. (III. 7.) AB határozat, Indokolás [48]

${ }^{88}$ Uo., Indokolás [57]

${ }^{89}$ Uo., Indokolás [57]

${ }^{90}$ Uo., Indokolás [61]
} 
Mindezek után a legkevésbé sem meglepö, hogy az Alkotmánybíróság az Alaptörvény hatálybalépését követő első adódó alkalommal büntetőjogi kontextusban is újra deklarálta ezeket a tételeket. A 13/2014. (IV. 18.) AB határozat részletes okfejtésének bemutatására a fenti két határozat ismertetése után már nincs szükségünk, mivel érdemileg teljes mértékben azonos érveken nyugszik. Feltétlenül érdemes azonban idéznünk az indokolásnak azt a tételszerü kijelentését, amelyben a testület a mérlegelés lényegének rációját ragadja meg. Eszerint a közéleti szereplők korlátozott személyiségvédelmére vonatkozó megfontolások alapja az, hogy ,a közügyeket érintő véleménynyilvánítás középpontjában elsősorban a politikai közösség demokratikus működése és nem a szólással, bírálattal érintett közszereplő személye áll". ${ }^{91}$ A szólásszabadság és a közlésekkel okozott bántalmak ütközése feloldásának eddig elemzett alapszemléletét ismerhetjük itt föl: mérlegelésünk vezérfonala nem az egyéni sérelmek jogi orvoslásának feltétlen igénye, hanem az egyik legalapvetőbb demokratikus-közösségi követelmény, a szabad közéleti diskurzus érvényesülésének szempontja.

Nyilvánvaló, hogy ha az alkotmányos gyakorlatot még a konkrét alanyi jogok érintettsége esetén is ez az alapállás jellemzi, akkor nem lehet más a mérlegelés irányelve egyéb, elvontabb módon jelentkező sérelmek esetén. Az ártalmak áttekintésekor láttuk, hogy a véleménynyilvánítás joga számára korántsem ismeretlen a csoportos, társadalmi bántalmak elismerése, ám szólásszabadsággal szembeni érvényesítésükre különösen szük körben, speciális többletkövetelmények esetén nyílik csak lehetőség. Ez sem azért van így, mert a jog érzéketlen akar lenni közösségi szempontokkal szemben, hanem mert érzékeny akar maradni valamennyi közösség közös ügye, a társadalom demokratikus, részvételi müködése iránt. A közéleti párbeszédben vitatkozó korlátozására nem elegendő érv, hogy amit mond, az egyesek számára sértő, lealacsonyító stb. Tudjuk, hogy az (tud lenni). Ha máshonnan nem, hát az Alkotmánybíróság gyakorlatából mindenképp. A testület már a 30/1992. (V. 26.) AB határozatban kinyilvánította, hogy a közvélemény alakulásában mindenféle véleménynek helye van, azoknak is, amelyek sértőek mások számára, mivel az egyéni véleményalkotás alkotmányos védelem alatt áll. ${ }^{92}$

\footnotetext{
91 13/2014. (IV. 18.) AB határozat, Indokolás [26]

92 30/1992. (V. 26.) AB határozat, Indokolás V.3., ABH 1992, 167, 179.
} 
Még világosabban fogalmazza ezt meg a szintén a gyülöletbeszéd alkotmányos határait kereső 95/2008. (VII. 3.) AB határozat. Eszerint az általánosító, azaz nem konkrét személyeket célzó beszéd korlátozásánál azt kell szem előtt tartani, hogy „,[a]z alapjogi védelem [...] nem tagadható meg pusztán azon az alapon, hogy az elhangzottak mások érdekét, szemléletét, érzékenységét sértik, vagy azok egyes személyekre nézve bántóak, lealacsonyítóak". 93 A határozat indokolása nem kertel: tudja, hogy a közvitában egyesek mások számára elfogadhatatlan, lealacsonyító módon fejezik ki magukat. Tudja, hogy a gyalázkodó beszéd társadalmi csoportok érzékenységét, sőt mi több, érdekeit is sértheti. És mégis: a szólásszabadságnak mindezzel együtt elsőbbséget ad, mivel e nélkül megszünne alapjogként funkcionálni a jog-központú megközelítés számára nem elegendő ellenérv önmagában (további tényezők nélkül) a sértettség, az érdeksérelem vagy a megvetettség.

Érdemes még rámutatni arra, hogy egyik megjegyzésével az Alkotmánybíróság e helyütt is utalást tesz arra, amire már a 7/2014. (III. 7.) AB határozat elemzésekor kitértünk, ti. hogy bár a véleményszabadság a bántalmak elismerése mellett is védelmet kap, előfordulhat, hogy a látszat - vagyis felszínre jutó érzékenységek ellenére valójában nincs jogilag megragadható sérelem. A testület szerint a jól és tisztességesen müködő demokratikus közvélemény ugyanis eleve minimalizálja az ilyen közlésekkel okozható hátrányokat. Arról van szó, hogy ,[h]a a politikai élet alakítói elkötelezettek az Alkotmány alapértékei mellett, és következetesen megnyilvánulnak a kirekesztő nézetekkel szemben, akkor kifejezésre juttatják, hogy a megsértett csoportokhoz tartozók megfelelő támogatást és védelmet kapnak a politikai közösségtöl. Ilyen környezetben a gyülölet, a megvetés és az ellenérzés hangjai elszigetelődnek, jelentéktelenné válnak és nem képesek jogsérelmet okozni." ${ }^{94}$

Az elmúlt évtizedek tapasztalatára hivatkozva sokan ezt a víziót tündérmesének tartják, holott az elmúlt időszak keserü tanulságait követően éppen az állapítható meg nyugodt szívvel: ameddig nem próbáltuk ki ezt a receptet (márpedig eddig nem sikerült), nincs okunk megkérdőjelezni meggyőzőnek tűnő igazságát.

\footnotetext{
93 95/2008. (VII. 3.) AB határozat, Indokolás III.2.1., ABH 2008, 782, 786.

${ }^{94}$ Uo., Indokolás III.4.3., ABH 2008, 793.
} 


\section{Következtetések}

1. A szólásszabadság nem ártalmatlansága miatt nyer kiemelt védelmet, hanem éppen a szólásokkal okozható bizonyos bántalmak ellenére, mivel csak így képes biztosítani a demokrácia müködéséhez elengedhetetlenül szükséges jogot a szólásra.

2. Míg a szólások veszélyes következményei megfelelő kauzális kapcsolat esetén kellő alapot nyújtanak a beavatkozásra, addig a szavak puszta meghallásából fakadó („,bennerejlő”) sérelmek nem igazolhatnak széles körű szabályozást.

3. A szólások ártalmainak helyét a jogi mérlegelésben kijelölő módszertani szabály, hogy a bántalmaknak annál nagyobb a súlya, minél inkább felfoghatók egyéni alanyi jogi sérelemként.

3. A szóban forgó sérelem pontos azonosítása konkrét mércék tisztázását segíti: míg a rémhírterjesztés tesztje a „nyilvánvaló és közvetlen veszélyhelyzet”, addig az uszításnál már a veszély valamivel enyhébb (valós, belátható) alakzata is korlátozást indokolhat, mivel az uszító alanyi jogokat veszélyeztet.

4. A gyalázkodás - mint „bennerejlő ártalmakat” hordozó szólás - nem büntethető.

5. A főszabállyal feszültségbe kerülő határozatok rendszerbeli helyét akkor találhatjuk meg, ha a bennük vizsgált sérelmek megkülönböztetésével sajátos és kivételes tesztekként tekintünk rájuk, amelyek az érintett ártalmak egyedisége miatt nem terjeszthetők ki további esetekre.

6. Közösségi érzékenységet, türésküszöböt védő és azt mindenkire ráerőltető (,asszimilációs”) jogalkotásra kivételes és szük körben kerülhet csak sor: a nemzeti jelképek esetében az „egységesítő törekvés” - az alkotmányban nevesített szimbólumok révén - a magyar politikai közösség egyetlen tagja számára sem kirekesztő, mivel nem egyes kulturális, vallási, nemzetiségi közösségek speciális normáira vagy érzékenységére szabott.

7. Az önkényuralmi jelképek használatát és a diktatúrák bűneinek tagadását tiltó szabályok helyes értelmezés mellett nem mások érzékenységét óvják, hanem legféltettebb demokratikus alkotmányos eszméink aláásása ellen védenek.

8. A közösséget sértő közlések szankcionálására csak további speciális körülmények között kerülhet sor: a „foglyul ejtett közönség” esetében a szituatív 
tényezők, az ,átsugárzás” polgári jogi megoldásánál a védelem tárgyának (az emberi méltóság korlátozhatatlan magjának) különlegessége tekinthető ilyennek.

9. A sérelmek értékelésének alapszemlélete: a sérelmek helyét és jelentőségét mindig annak figyelembevételével kell kijelölni, hogy a szólásszabadság alkotmányos joga érvényesülni tudjon.

10. A következetes joggyakorlat a sérelmek jogi orvoslásának még egyéni jogok érintettsége esetén is megálljt parancsol, ha az a közügyek demokratikus vitáját ellehetetlenítené vagy jelentősen megnehezítené. 


\section{A SZÓLÁSKORLÁTOK TARTALOMSEMLEGESSÉGÉNEK RELEVANCIÁJA}

Ha utánajárnánk annak, hogy a szólásszabadság korlátozásának alapkérdései közül melyik tételt, alapelvet, módszertani szabályt emlegeti legtöbbet elmélet és gyakorlat, akkor minden bizonnyal az a nagyhatású tézis futna be első helyen, mely szerint magára valamit is adó demokrácia a véleménynyilvánítást annak tartalma alapján nem korlátozza. A tartalomalapú és tartalomsemleges beavatkozások közti alapvető különbségtétel a szólásszabadságról való gondolkodás egyik csomópontja, amely óriási szeletet követel magának a szakirodalomból. A kérdéskör jelentőségét ráadásul nem kerülhetjük meg azzal, hogy csupán az amerikai irodalom túlsúlya miatti optikai csalásról van szó, és az európai jogfelfogás valójában más alapokról építkezik: a téma beható vizsgálata nemcsak hogy hasznos, hanem egyenesen megkerülhetetlen a véleményszabadság magyar doktrínájának tisztázásakor. Több oka is van ennek. Mindenekelőtt persze maga a hazai alkotmánybírósági gyakorlat, amely szerint a közlések korlátozásának tartalomsemlegessége az alkotmányossági mérlegelés egyik alapeleme. Látni fogjuk, hogy a határozatok indokolása hangsúlyosan jeleníti meg ezt a problematikát, és e tekintetben ez a kérdéskör épp egy olyan terület, ahol a magyar gyakorlat más európai irányokhoz, mindenekelőtt a strasbourgi bíróság esetjogához viszonyítva többet merített az amerikai megközelítésből. Továbbra sincs szó arról, hogy a szólásszabadság gyakorlatát a tengerentúli megoldásokkal azonos módon építgetnénk, de arról feltétlenül beszélhetünk, hogy ebben a körben a magyar érvelés az európai átlagnál jellegadóbban honosította meg az Egyesült Államokban bevett tartalomszempontú vizsgálatot. Másrészt ennek hatására mára a hazai irodalomban is mélyen gyökerezik a szemléletmód, amely a véleményszabadsággal kapcsolatban felmerült kérdéseket, szóláskorlátozásokat a „tartalmi vagy nem tartalmi” szűrőn keresztül (is) elemzi.

Ettől teljesen elkülönülő kérdés, hogy abban már teljesen igaza van a tartalomsemlegesség tézisét kritizálóknak, hogy a magyar joggyakorlatban ezt a tételt olyan erejű kihívások érik, amelyek akár alapjaiban rengethetik meg a jelentőségét. A tartalomsemlegesség követelményét megerősítő, sőt szerepét a korábbiaknál is markánsabban hangsúlyozó 95/2008. (VII. 3.) AB határozathoz írt fontos párhuzamos 
indokolás szerint a tézis a hazai gyakorlatban „módszertani szempontból kifogásolható”, és „tartalmi torzulást” eredményezett az Alkotmánybíróság döntéseiben. ${ }^{1}$ A párhuzamos indokolás jogosan mutat rá ugyanis arra, hogy „,az Alkotmánybíróság vonatkozó gyakorlatában a tartalomsemleges korlátozás elvét megtestesítő [határozatok] mellett léteznek a tartalomorientált korlátozás elvét követő döntések is". 2

Épp ezen kihívások miatt sürgető, hogy a joggyakorlatban és a jogirodalomban úton-útfélen emlegetett elv jelentését és helyét a túlnyomórészt csak odavetett hivatkozásoknál pontosabban és elemzőbben igyekezzünk megtalálni. Nem vitás, hogy a tartalomalapú korlátozások megítélése a hazai szólásszabadság-diskurzus tisztázásért kiáltó kérdésköre. Ha azt gondoljuk, hogy ezzel a problémával egyedül vagyunk, és most nem lehet segítségünkre a mégoly kiterjedt amerikai elméleti arzenál sem, mivel ott kikezdhetetlenül tartja magát a tartalomsemlegesség követelménye, akkor szerencsére - tévedünk. A tengerentúli elemzők pont azért dagasztották mára már szinte áttekinthetetlen méretűvé a vonatkozó kérdésekkel foglalkozó szakirodalmat, mert a doktrínát magyarázó számára ott is nehezen - ha egyáltalán - kibogozható dilemmát jelent a gyakorlat rajzolta valóság. Felütés és kedvcsinálás gyanánt hadd idézzek egymástól egyébként viszonylag távolálló álláspontot képviselő teoretikusok értékeléséből. A tartalomközpontú megközelítés mellett érvelő Geoffrey Stone szerint alighanem a kortárs szólásszabadság doktrína legfogósabb kérdése a tartalomalapú és a tartalomsemleges korlátozások közti, egyre többet hivatkozott különbség. ${ }^{3}$ Steven Shiffrin a véleménynyilvánítás jogának módszertanában való rendrakás egyik első őszinte kiindulópontjaként szögezi le: míg a joggyakorlatban sokszor mindenre kiterjedően hivatkozott tétel szerint a szólásszabadság mindenekelőtt azt jelenti, hogy az állam nem korlátozhatja a közléseket azok mondanivalója, tárgya vagy más tartalmi jellemzője alapján, addig a kommunikáció tényleges jogi szabályozását elemző bármely értékelésnek azzal a felismeréssel kell kezdenie, hogy az állam korlátozhatja a közléseket azok tartalma alapján. ${ }^{4}$ Ezek után pedig nem lehet csodálkozni azon sem, ha

\footnotetext{
1 95/2008. (VII. 3.) AB határozat, Dr. Lévay Miklós alkotmánybíró párhuzamos indokolása, I.1., ABH 2008,804

${ }^{2}$ Uo., I.2., ABH 2008, 804.

${ }^{3}$ Geoffrey R. STONE: Content Regulation and the First Amendment. 25 William and Mary Law Review 189 1983-1984. 189.

${ }^{4}$ Steven SHIFFRIN: Defamatory Non-media Speech and First Amendment Methodology. 25 UCLA Law Review 915 1977-1978. 955.
} 
egyesek, mint például Martin Redish, arra jutnak, hogy ideje újragondolni, majd ennek eredményeként megszabadulni a tartalomközpontú megközelítéstől. ${ }^{5}$

A dolgozat következő fejezetének célja nem az, hogy megszabadítsa gondolkodásunkat a tartalomsemlegesség követelményétől, hanem hogy megpróbálja helyretenni annak valódi jelentését és jelentőségét a magyar doktrínában. Látni fogjuk, hogy e vizsgálat során a szólásokkal és ártalmaikkal foglalkozó előző fejezettel újra meg újra összefonódó érveket találunk majd, a korlátozások tartalmi szempontú megközelítését mégis önállóan érdemes és kell körbejárnunk, mert kulcsfontosságú hangsúlyokra hívja fel a figyelmünket. Ezen hangsúlyok az előző fejezet tanulságainak fontos kiegészítői, amelyek egyszersmind új megvilágításba is helyeznek egyes részleteket.

\section{Elméleti keretek a tartalomsemlegesség megragadásához}

Mindenekelött vegyük számba azokat a lehetséges elméleti szempontokat, amelyek közelebb vihetnek minket a tartalomsemlegesség követelményének azonosításához. Annak ellenére, hogy ezek a szempontok egy e tekintetben különösen is sajátos amerikai esetjog magyarázatában gyökereznek, nagy segítségünkre lesznek abban, hogy vizsgált tételünk helyét és jelentőségét átfogóbban és megalapozottabban lássuk a magunk doktrínájában. A tartalmi és a tartalomtól független korlátozások közötti különbségtétel értelméről és jelentéséről a szokásosnál is pezsgőbb és szerteágazóbb diskurzus zajlik az amerikai jogirodalomban, így nem kis kihívást jelent a releváns szempontok kiemelése. Azt gondolom, a magyar doktrína elhelyezéséhez az alábbi elméleti szempontok tünnek a leghasznosabbnak.

\subsection{A kérdéskör alapvonalai}

A teoretikusok már azt megelőzően igyekeztek kibontani a szóláskorlátozások vizsgálatának két eltérő útját, amikor annak még csak első nyomai jelentek meg a

\footnotetext{
${ }^{5}$ Martin H. REDISH: The Content Distinction in First Amendment Analysis. 34 Stanford Law Review 113 1981-1982. 114. Redish teóriájára átfogóan lásd Martin H. REDISH: The Adversary First Amendment. Free Expression and the Foundations of American Democracy. Stanford Univerity Press, 2013
} 
joggyakorlatban, vagy legalábbis a tartalomsemlegesség kérdése még nem volt a későbbiekhez fogható módon döntő eleme a doktrínának. A kérdéskör elemzésének ezt a hőskorát leginkább John Hart Ely és Laurence H. Tribe nevéhez köthetjük, akiknek a gondolatai a későbbi szerzők számára is a téma kiindulópontjául szolgálnak.

Ely a vizsgálat szempontjait mindenekelőtt az amerikai Legfelső Bíróság két híres ügyének összehasonlításával szemlélteti, ${ }^{6}$ amelyek fókuszában egyaránt a katonai sorozás elleni tiltakozás állt, mégis radikálisan eltérö bírói döntésre vezettek: míg a behívót elégető O’Brien elmarasztalása alkotmányosnak bizonyult, ${ }^{7}$ addig a dzsekijén a besorozás ellen buzdító trágár kifejezést viselő Cohen elítélése nem állta ki a legfőbb fórum próbáját. $^{8}$ Miután O’Brien cselekményének kétségtelen kommunikációs üzenetére tekintettel a két ügy eltérő kimenetele nem volt magyarázható a korábban divatos megkülönböztetéssel, mely szerint a szólásszabadság a szavakat igen, az egyéb cselekményeket nem védi, Ely új, „,teleologikus érvek” felé fordult (from ontology to teleology). Szerinte a döntések csak annak a vizsgálatnak a jegyében érthetők meg, hogy vajon a szólás korlátozását támogató érdek a véleménynyilvánítás elhallgattatásához kötődik-e. Nem annak van perdöntő ereje, hogy a szabályt alkotó milyen érveket hoz fel a korlátozás érdekében, hiszen a kormányok a legritkább esetben szokták csak elismerni, hogy céljuk egy vélemény elhallgattatása. A releváns kérdés az, hogy a veszély vagy sérelem, amit a korlátozás elhárítani igyekszik, pusztán a megszólaló kommunikációjából vagy hallgatóinak feltételezett reakciójából származik-e, avagy akkor is felmerülne, ha a cselekménynek semmilyen kommunikatív aspektusa nem lenne. Ely már előrebocsátja azt, amit későbbi szerzők a bővülő joggyakorlatra reagálva majd alaposan kibontanak: nem elégedhetünk meg a tartalom (regulation of content) és a közlés körülményei (regulation of time, place and manner) szabályozásának elkülönítésével, mivel nyilvánvaló, hogy az állam az utóbbi leple alatt gyakran a közönségre gyakorolt hatást igyekszik befolyásolni. A kritikus pont tehát Ely szerint az, hogy az állított veszélyek kizárólag a kommunikációs tartalomból erednek-e (flowed entirely from the communicative content). Sokat idézett megfogalmazása szerint: Cohen felirata semmilyen következménnyel nem járt volna, ha a körülötte lévők nem tudtak volna angolul olvasni, míg O’Brien esetében a behívó

\footnotetext{
${ }^{6}$ John Hart Ely: Flag Desecration: a Case Study in the Roles of Categorization and Balancing in First Amendment Analysis. 88 Harvard Law Review 1482 1974-1975

${ }^{7}$ United States v. O’Brien, 391 US 367 (1968)

${ }^{8}$ Cohen v. California, 403 US 15 (1971)
} 
elégetése kommunikációs szempontoktól teljesen függetlenül is érintette az állam sorozással kapcsolatos érdekeit. ${ }^{9}$

Tribe még szisztematikusabban dolgozta ki az Ely elemzésével egyébként hasonló következtetésekre jutó téziseit. ${ }^{10}$ Álláspontja szerint az állam kétféleképpen sértheti a szólásszabadságot, ami az alkotmányossági vizsgálat két eltérő útját generálja. A jogsértés egyik formája, amikor az állam fellépése a közlések kommunikatív hatására irányul (aimed at communicative impact), a másik, amikor a beavatkozást más célok vezérlik ugyan (aimed at non-communicative impact), a közlési lehetőségekre mégis hátrányos kihatással van. Tribe világossá teszi a megkülönböztetés tétjét is: bármely állami intézkedés, amely az első csoportba tartozik, vélelmezhetően sérti a szólásszabadság követelményeit. Az alkotmányos vizsgálat jellemzője ebben a körben az abszolutista hozzáállás, amely semmilyen beavatkozást nem enged, míg a másik körben elötérbe kerül a mérlegelő megközelítés, amely a versengő értékek összemérésén alapul. A korlátozások első, szigorúbb vizsgálatot igénylő csoportjába nem csupán azok az esetek tartoznak, amikor az állami beavatkozás egyértelműen (on its face) bizonyos gondolatokat vagy információkat céloz, hanem azok is, amikor a látszólag semleges intézkedést valamely véleménynyilvánítás elnyomásának szándéka motiválta (motivated by). Elyhez hasonlóan Tribe is kiemeli ugyanis, hogy a kormányzatok minden esetben előszeretettel hivatkoznak valamely, a szólás tartalmán túli veszélyre, ám a körülmények szabályozásának talizmánjára (talisman of time, place and manner) utaló korlátozás sok esetben jogosan ébreszt komolyabb gyanút. ${ }^{11}$ Ami a kommunikáció tartalmától valóban független korlátozásokat illeti, az alkotmányos vizsgálat enyhébb módszerének lényegét Tribe abban látja, hogy ezeknél az intézkedéseknél is fennmarad a kérdés, elegendő teret hagynak-e a vélemények és információk áramlásának. ${ }^{12}$

Ahogy az egyre szövevényesebbé váló amerikai joggyakorlat minél inkább a tartalomsemlegesség vizsgálatát tette meg a doktrína központi kérdésévé, úgy jelentek meg a megközelítés abszolutizálását kritizáló álláspontok. Ezek közül rendkívül tanulságos kitérnünk Martin Redish szempontjaira, attól függetlenül, hogy a tartalomközpontú megközelítés elvetésére vonatkozó végső következtetésével

\footnotetext{
${ }^{9} \operatorname{ELY}$ (6. lj.) 1495-1498.

${ }^{10}$ Laurence H. TRIBE: American Constitutional Law. Mineola, NY, The Foundation Press, 1978, § $12-$ 2., § 12-3., § 12-20.

${ }^{11}$ TRIBE (10. lj.) 580-585.

${ }^{12} \operatorname{TRIBE}(10$. lj.) 682-683.
} 
egyetértünk-e vagy sem. ${ }^{13}$ Redish szerint a tartalomalapú korlátozásoknak szigorú, míg az egyéb korlátozásoknak kevésbé szigorú alkotmányossági vizsgálatot rendelö álláspont képviselői - mindenekelőtt Ely és Tribe - két téves előfeltevésből indulnak ki. Egyrészt abból, hogy az előbbi kör szükségszerüen jobban veszélyezteti a szólásszabadságot, mint az utóbbi, másrészt abból, hogy a két kör fogalmilag jól elhatárolható. ${ }^{14}$ Ezzel szemben Redish azzal érvel, hogy bármilyen természetű is legyen ebből a szempontból az állam beavatkozása, az mindenképp fékezi a vélemények és információk áramlását, és így veszélyt jelent a szólásszabadságot igazoló értékekre. ${ }^{15}$ Továbbá az sem állítható, hogy a gyakorlatban jól alkalmazható distinkciót lehetne tenni a tartalomalapú és a tartalomsemleges korlátozások között, amit jól mutat az is, hogy mind Ely, mind Tribe az elöbbi körbe már eleve bevonja a tartalmon túli körülmények, legfőképpen a motiváció vizsgálatát. Redish szerint a bizonytalanságokat igazolja az is, hogy a gyakorlat nem nagyon tud mit kezdeni a kommunikáció tárgyát érintő intézkedésekkel (subject-matter regulation), és hol a szigorúbb, hol a megengedőbb tesztet alkalmazza velük szemben, amiért ő maga például föszabályként eleve csak a nézőpontok között különbségtételt (viewpoint regulation) érti a tartalomalapú korlátozás terminusa alatt. ${ }^{16}$ De hasonló besorolási probléma adódik, ha megpróbáljuk megkülönböztetni egymástól a szólások tartalmát és módját (manner) érintő szabályokat. Minderre tekintettel a szólások korlátozását tartalomsemlegességükre tekintet nélkül a szigorúbb vizsgálatnak kell alávetni, és kizárólag kényszerítő erejű érdek (compelling interest) fennállása esetén meghagyni. Redish nem tagadja, hogy a tartalomalapú korlátozások mindenképpen nagyobb arányban akadnak fenn az alkotmányossági szürőn, de ennek oka nem más beavatkozásokhoz képest különlegesebb veszélyükben rejlik, hanem abban, hogy más intézkedések esetén az állam több kényszerítő körülményre tud megalapozottan hivatkozni. Ettől még abból, hogy alapvető hiba a szólásszabadságot bizonyos tartalmú véleményekkel való nézeteltérés miatt korlátozni, nem következik, hogy helyénvaló más okból tenni ugyanezt. ${ }^{17}$ Redish szerint az a lehetséges ellenvetés, mely szerint az egységes mérce alkalmazása a tartalomalapú korlátozásokra is kiterjedő mérlegelő

\footnotetext{
${ }^{13}$ A megközelítés jelentette kihívásokra lásd még: Stone 3. lj.

${ }^{14}$ Martin H. REDISH: The Content Distinction in First Amendment Analysis. 34 Stanford Law Review 113 1981-1982. 114.

${ }^{15}$ Redish számára e tekintetben nincs jelentősége annak, hogy miben látjuk a szólásszabadság igazolását: a korlátozások mind a vélemények piacának szabadságát, mind a demokratikus folyamatok dinamikáját, mind pedig az egyéni kiteljesedést hátráltatják.

${ }^{16}$ REDISH (14. lj.) 118 .

${ }^{17} \operatorname{REDISH}$ (14. lj.) 134.
} 
tesztet eredményezne, nem perdöntő, mivel egyrészt a doktrína ebben a körben sem helyezkedett valóban abszolutista megközelítésre, másrészt a szólásszabadság valódi védelmét - bármely módszerről legyen is szó - csakis a javára szóló elfogultság biztosithatja. $^{18}$

A tartalomalapú és a tartalomsemleges korlátozások radikális megkülönböztetésén alapuló gyakorlatot természetesen többen is védelmükbe vették. A kritikákra, köztük Redish érveire átfogó választ fogalmazott meg Geoffrey Stone, aki mindenekelőtt elismeri, hogy a kritikusok helyzetelemzése két fontos ponton helytálló. Egyrészt a joggyakorlat valóban az alkotmányossági vizsgálat két radikálisan eltérő módszerét dolgozta ki: míg a tartalomsemlegesnek minősített szabályoknak egy mérlegelésen alapuló teszten reális esélyük van a túlélésre, addig a tartalomalapú korlátok gyakorlatilag esélytelenek a szigorúbb vizsgálattal szemben. Másrészt a tartalomsemleges korlátozások sok esetben nemhogy azonos mértékü, hanem nagyobb megszorítást tudnak eredményezni a vélemények és az információk össztársadalmi áramlásában. ${ }^{19}$ Stone ennek ellenére egyértelműen úgy látja, hogy a gyakorlatnak ez a megközelítése négy, egymást erősítő érv alapján igazolható és továbbra is követendő. Először is, a kérdés kapcsolatban áll az egyenlőség alkotmányos értékével, mivel a tartalomalapú korlátozások bizonyos álláspont képviselőit másokhoz képest hátrányosabb helyzetbe hoznak, míg semleges szabályozásnál ez a probléma jobbára nem merül föl. Másodszor, a tartalmi fókuszú megközelítés jelentős részben egybevág azzal a kérdéssel, hogy a szabályozás az érintett közlések kommunikatív hatását célozza-e, márpedig a szólásszabadság bármely igazolása döntő mértékben szembehelyezkedik a polgárait paternalista módon védő vagy a mások nézeteivel szembeni intoleranciát méltányoló állam gondolatával. Harmadszor, a szólásszabadság doktrínája nem pusztán a kommunikáció mennyiségének csökkentésével törődik, hanem még inkább a közösségi vita torzulásával, amelyet kétségkívül nagyobb mértékben érint a bizonyos nézeteket és gondolatokat célzó szabályozás, mint a bármely széles körre kiterjedő semleges szabály. Negyedszer, a megkülönböztetés az alapján is indokolt, hogy a tartalomalapú korlátok többnyire a kormányzatoknak a nekik nem tetsző gondolatok elhallgattatására irányuló motivációjára utalnak, amely szándék a szólásszabadság értékeivel feloldhatatlan ellentmondásban áll. Míg például a

\footnotetext{
${ }^{18}$ Redish Kalven klasszikus fordulatát vesz át: „thumb on the scales in favor of free speech”. Harry Kalven: The Concept of the Public Forum: Cox v. Louisiana. 1965 Supreme Court Review 1, 28.

${ }^{19}$ STONE (3. lj.) 197.
} 
paternalizmus alól szük körben elképzelhetők a véleményszabadság szempontjából menthető kivételek (ide sorolja például a clear and present danger tesztet), addig a nézetek között szelektáló állam motivációja menthetetlen. Stone szerint bár e négy megfontolás külön-külön talán nem igazolná kellő mértékben a tartalomközpontú megközelítést, együttes erejük már mindenképpen meggyőző. ${ }^{20}$ Annak ellenére így látja, hogy egyébként ő maga sem tagadja az elhatárolási nehézségeket. Bár az alapvető definíciót Stone jól hangzó egyszerüséggel adja meg - eszerint a tartalomsemleges szabály a véleménynyilvánítást a közvetített üzenetre való tekintet nélkül (without regard to the message conveyed), míg a tartalmi alapú épp amiatt (because of the message conveyed) korlátozza -, a besorolás különösen nehéz esetköreit nevesíti. (1) Vannak tartalomsemleges szabályok, amelyek valójában a vélemények kommunikatív hatásán alapulnak (content-neutral restrictions that turn on communicative impact), ezért a szokásos enyhébb mércénél mindenképpen szigorúbb vizsgálatot érdemelnek. Ilyen lenne például az utcai plakátolás mint különösen tolakodó kommunikációs csatorna teljes tiltása, vagy bármely üzenet nyilvános közvetítésének letiltása elöre meghatározott számú panasz beérkezése nyomán. (2) Stone szerint nincs generális feloldása annak a besorolási problémának sem, hogy milyen mércével vizsgálandók az üzenet tárgya szerinti korlátozások (subject-matter restrictions). Az ezeket konkrét megjelenési formájuk alapján hol ide, hol oda soroló joggyakorlat bizonytalankodását teljesen érthetőnek látja, mivel ezek sok esetben a klasszikus nézőpontalapú beavatkozáshoz képest kisebb veszélyt jelentenek a szólásszabadságra, így a rájuk alkalmazandó mérce csak annak ismeretében választható ki, hogy a konkrét szabály mennyiben veti föl a tartalomalapú intézkedések kockázatait. (3) Sajátos esetet jelentenek a trágárságot (profanity) korlátozó szabályok, mivel azok a közlés tartalmára vonatkoznak, mégsem feltétlenül követelik meg a legszigorúbb vizsgálatot. Stone szerint ez esetben valójában nem bizonyos gondolatok korlátozásáról van szó, hanem a másokat zavaró kommunikáció olyan formájának szabályozásáról, amely sokkal inkább hasonlít a zajterhelés kordában tartására. Nem kétséges ugyanakkor, hogy a trágár módon kifejezett üzenet fontos érzelmi töltetet hordozhat, továbbá korlátozása egyeseket jobban érint, de ezeknek a kockázatoknak a kezelésére Stone a tartalomsemleges intézkedésekre vonatkozó mérlegelést is alkalmasnak tartja. (4) Sajátos megjelenési formái lehetnek végül a megszólalók

\footnotetext{
${ }^{20}$ STONE (3. lj.) 201-233.
} 
szerint különböztető korlátozásoknak (speaker-based restrictions), amelyeket Stone a kommunikáció tárgya szerinti szelektáláshoz hasonlóan - esetről esetre tart csak besorolhatónak. Mindezekből az elhatárolási problémákból láthatóan Stone a tartalomalapú beavatkozás szigorú szempontjait vegytisztán igazából csak egy esetkörre, az egyes gondolatok vagy nézőpontok elhallgattatására irányuló intézkedésekre (viewpoint-based restrictions) tartja irányadónak. E tekintetben a tartalomra fókuszáló dichotóm megközelítést azzal együtt helyesnek tartja, hogy a kritikusok a doktrína nehézségeire több ponton helyesen mutatnak rá. ${ }^{21}$

\subsection{Kiútkeresés új megközelítésekkel}

Az eddig kifejtett gondolatok tekinthetők a tartalomalapú és a tartalomsemleges korlátozások elkülönítéséhez kötődő elméleti vita alapvonalainak. Ezek mentén később az amerikai jogirodalom páratlanul gazdag diskurzusa alakult ki és folyik mind a mai napig, amely szoros kapcsolatban áll a szóban forgó dichotómiának az esetjogban egyre ellentmondásosabbá váló útjával. A szerzők arra a legfelső bírósági judikatúrára igyekeznek reflektálni, amely a felmerülö tényállások és problémák egyre sokszínübbé és részletesebbé válásával éppen hogy egyre mechanikusabban látszik alkalmazni a tartalmi szempontú megközelítést. E dolgozatnak nem célja a tengerentúli joggyakorlat nyomon követése, a későbbi szerzők néhány fontos gondolata viszont megtermékenyítő lehet számunkra a magyar doktrína megfogalmazásához. Noha a vita gazdagságára tekintettel bármilyen összegző kijelentés bátorságot igényel, megkockáztatom, hogy az elemzések fösodra a merev dichotómia alkalmatlanságára vagy legalábbis korlátaira és kockázataira hívja föl a figyelmet. Ez természetesen nem feltétlenül jelenti a megközelítés teljes elvetését vagy hasztalanságát, de tekintetünket hangsúlyosabban fordítja más szempontok felé, azzal érvelve, hogy bizonyos mértékü újrahangolás nélkül a hagyományos tartalomközpontú megközelítés kiüresedik. Ezek a szempontok nem lesznek ismeretlenek a számunkra, hiszen gyökereik vagy akár konkrét azonosításuk a korábbi szerzők gondolatmenetében is megtalálhatók.

A diskurzus egyik markáns fonala mentén olyan álláspontokat találunk, amelyek szerint az alkotmányossági vizsgálat fókuszába nem is annyira a tartalmi érintettség

\footnotetext{
${ }^{21}$ StOne (3. lj) 251.
} 
kérdését, hanem a beavatkozó állam motivációját kell helyeznünk. A motiváció kérdése korábban is fontos pontja volt az elemzéseknek, de a későbbi szerzők - nem is annyira a megelőző irodalommal, mint inkább a folyó gyakorlattal vitázva megfordítják a gondolkodás irányát: míg eddig a motiváció leginkább a tartalmi megközelítés egyik mögöttes igazoló elveként jelentkezett, addig számukra ez válik a központi kérdéssé, amelynek vizsgálatához a tartalmi megközelítés fontos, de semmiképp sem kizárólagosan perdöntő módszer lehet.

Frederick Schauer lakonikusan szögezi le, hogy számára a szólásszabadság középpontjában az állam motivációja áll. ${ }^{22}$ Szerinte ebből az alapállásból nézve azok a szabályok, amelyek nem kötődnek a közlések kommunikációs hatásához, csupán mellékes (incidental) korlátozásnak tekinthetők, és lényegesen enyhébb mércével vizsgálandók.

Ashutosh Bhagwat szerint az alkotmányossági vizsgálat lényege a beavatkozás céljának azonosítása, tüzetes vizsgálata és az elfogadhatatlan motivációjú intézkedés elvetése. $^{23}$ Álláspontja szerint noha értékelendő a gyakorlat törekvése, mely a tartalomsemlegesség vizsgálatát a nem megfelelő indítékok kiszürésére használja, ${ }^{24}$ a tartalmi megközelítést összességében súlyos következetlenségeket eredményezö módszernek tartja ebböl a szempontból, mivel egész egyszerüen nem a valójában perdöntő kérdést állítja a fókuszba. Kétségtelen, hogy a tartalomalapú korlátozások motivációja sokszor a célba vett véleményekkel szembeni ellenérzés, ami nyilvánvalóan elfogadhatatlan indíték, de ez nem mindig van így, ami miatt már önmagában véve is félrevezető a tartalmi vizsgálathoz kötődő kategorikus szemlélet. ${ }^{25}$ Másfelöl ugyanakkor a tartalomsemlegesnek tünő korlátozásoknál sok esetben az enyhébb vizsgálatnál gyanakvóbb hozzáállásra van szükség.

Barry P. McDonald hasonló logikában tartja elégtelennek a szokásos dichotómia alkalmazását. Szerinte a tartalomközpontú megközelítés megrögzött alkalmazása két okból sem mozdítja elő a szólásszabadság egészséges és élénk világának ügyét. Egyrészt túlságosan megköti a jogalkotó kezét az olyan tartalmak szabályozásában is, amikor egyébként az illegitim motiváció kockázata meglehetősen csekély (például a

\footnotetext{
${ }^{22}$ Frederick SCHAUER: Cuban Cigars, Cuban Books, and the Problem of Incidental Restrictions on Communications. 26 William and Mary Law Review 779 1984-1985. 780.

${ }^{23}$ Ashutosh Bhagwat: Purpose Scrutiny in Constitutional Analysis. 85 California Law Review 297 1997

${ }^{24}$ Vö. az ún. „secondary effect” vizsgálatának gyakorlatával.

${ }^{25}$ BHAGWAT (23. lj.) 362.
} 
pornográfia vagy erőszakos tartalmak esetében). Másrészt éppen hogy nem szentel kellő figyelmet azokra a tartalomsemleges elöírásokra, amelyek akár nagyon széles körben is korlátozhatják, hogy mikor, hol és hogyan lehet kommunikálni. ${ }^{26}$

A mereven a tartalmi dichotómiára épülő joggyakorlatot ugyanakkor nem csupán a motiváció-vizsgálat hívei érezték kiegészítendőnek. Susan H. Williams bár elfogadja, hogy a doktrína főszabályként a kommunikatív hatás érintettségére fókuszál, az elhatárolás rugalmasabbá tétele mellett érvel. A tartalmi alapú korlátok megítéléséhez ugyanis nem elegendő csupán a szabályozó állam érvei vagy indítékai felől közelíteni, hanem más szereplök szempontjait is hangsúlyosabban kellene figyelembe venni. Álláspontja szerint mindenekelőtt a közönség érdekei alapján lehetne a tartalmi érintettség új formáit azonosítani: a befogadói oldal számára kulcsfontosságú, hogy egy adott szabályozás egyenlő mértékben érinti-e a gondolatok áramlását, vagy esetleg bizonyos nézetek terjedését aránytalanul hátráltatja. ${ }^{27}$

Tartalmilag hasonló problémákra épít $R$. George Wright gondolatmenete is, aki azonban végül Martin Redish radikálisabb következtetéséhez csatlakozik: önámításnak tartja, hogy a szólásszabadság rendkívül komplex világa egyetlen bűvös distinkció mentén értelmezhető lenne. A tartalomsemlegesség kérdése mind egyszerübb, mind továbbfejlesztett formáiban érzéketlen a véleményszabadság számos kérdésének megválaszolására. E helyett szerinte arra van szükség, hogy a közlések elnyomásának sokrétű veszélyeit jóval összetettebb szempontrendszer alapján vizsgáljuk. ${ }^{28}$

Végül, de legkevésbé sem utolsósorban Robert Post ebben a kérdéskörben is amellett érvel, hogy a mércéket „önmagukba zárva” alkalmazó szemlélet helyett kicsit magasabbra kell emelnünk a tekintetünket ahhoz, hogy a doktrínát megértsük és helyes irányba alakítsuk. A körülöttünk lévő világ ugyanis telis-tele van az emberi kommunikáció tartalmi korlátozásaival, amihez a jognak egy rossz szava nincs és nem is lehet. A nézőpontalapú korlátozás is hol alkotmányellenes, hol pedig (például egy osztályteremben vagy orvosi rendelőben) teljesen megalapozott lehet. Nem az tehát a kulcskérdés önmagában, hogy az állam neki nem tetsző gondolatot hallgattat-e el, hanem az, hogy tudja-e ezt igazolni a szólásszabadság számára. Mivel ez az igazolás

\footnotetext{
${ }^{26}$ Barry P. MCDONALD: Speech and Distrust: Rethinking the Content Approach to Protecting the Freedom of Expression. 81 Notre Dame Law Review 1347 2005-2006. 1352-1353.

27 Susan H. Williams: Content Discrimination and the First Amendment. 139 University of Pennsylvania Law Review 615 1990-1991. 658.

${ }^{28}$ R. George WrIGHT: Content-based and Content-neutral Regulation of Speech: the Limitations of a Common Distinction. 60 University of Miami Law Review 333 2005-2006. 364.
} 
mindig a véleménynyilvánítás alapértékeire mutat vissza, a döntő kérdés az, hogy ezek helyes azonosítása és értelmezése engedi-e vagy pedig tiltja a szóban forgó tartalmi diszkriminációt. $^{29}$

Post a tartalomközpontúság dichotómiája helyett egy négyosztatú táblázatban látja felrajzolhatónak a szólásszabadság-vizsgálat lényegi szempontjait. ${ }^{30}$ A különböző jogesetek, korlátozások aszerint kerülnek elhelyezésre a táblázat celláiban, hogy (1) a gondolatok közlésének szokásos csatornáját (medium for communication of ideas) érintik-e, illetve (2) a szólásszabadság számára releváns érdek (interest triggering First Amendment doctrine) azonosítható-e bennük. Post megoldásában nem tünik ugyan el a tartalomsemlegesség kérdése, hiszen a tartalmi alapú korlátozások önmagukban hatással vannak a véleménynyilvánítás érdekeire, de a hangsúly a mérlegelés összetettségére kerül. Így például attól még, hogy egy korlátozás nem különböztet tartalmi alapon, szigorú vizsgálata kitüntetett jelentőséggel bírhat a szólásszabadság számára, ha a kommunikáció fontos csatornáját szükíti.

Azt gondolom, ezek azok az elméleti felvetések és szempontok, amelyek birtokában kellő alappal fordulhatunk hazai joggyakorlatunkhoz, feltéve a kérdést: mit jelent a tartalomsemlegesség követelménye a magyar doktrína számára.

\section{A külső korlát fogalma}

Az, hogy a szólásszabadság magyar gyakorlatában a korlátozások tartalomsemlegességére vonatkozó érveknek fontos szerepük lesz, rögtön az első pillanatban valószínünek tünt. A 30/1992. (V. 26.) AB határozat a gyülöletre uszítás és a gyalázkodás eltérő alkotmányossági minősítésének alapvető téziseként szögezte le, hogy a szabad véleménynyilvánításhoz való jog a véleményt annak érték- és igazságtartalmára tekintet nélkül védi. A tartalomközpontú megközelítés klasszikus magyar megfogalmazása szerint „,[a] véleménynyilvánítás szabadságának külső korlátai vannak csak; amíg egy ilyen alkotmányosan meghúzott külső korlátba nem ütközik, maga a véleménynyilvánítás lehetősége és ténye védett, annak tartalmára

\footnotetext{
${ }^{29}$ Robert C. Post: Viewpoint Discrimination and Commercial Speech. 41 Loyola of Los Angeles Law Review 169 2007-2008. 173-174.

${ }^{30}$ Robert C. PosT: Recuperating First Amendment Doctrine. 47 Stanford Law Review 1249 1994-1995. 1256
} 
tekintet nélkül”. ${ }^{31}$ Az Alkotmánybíróság döntése e logika szerint arról szólt, hogy míg az uszítás a szólásszabadság külső korlátjába ütközik, addig a gyalázkodásnál ilyen külső korlát már nem húzható meg alkotmányosan.

Ami ekkor még csak nagyon valószínünek tünt, az később egyértelművé vált: a fenti érvek a szólásszabadság magyar doktrínájának központi megfontolásaivá váltak, az alkotmányossági mérlegelés egyik döntő elemévé téve a tartalmi érintettség vizsgálatát. Egyrészt a későbbi határozatok teljesen bevett formulájává vált az 1992-es indokolás idézett tézisének felhívása - gyakorlatilag nem találunk fontos döntést, amely valamilyen formában ne tenné ezt meg. ${ }^{32}$ Másrészt szemmel láthatóan nem csupán áhítattal mantrázott hivatkozásokról van szó, mivel a szólás- és sajtószabadságot átfogóbban elemző alkotmánybírósági értelmezések szinte kivétel nélkül egy-egy újabb fordulattal, hangsúlyozással hozzá is tesznek a korábbi passzusokhoz. Az 57/2001. (XII. 5.) AB határozat szavai szerint például a véleménynyilvánítás szabadsága ,a közlés lehetőségét jelenti, ami nem függ a tartalomtól, annak esetleges káros, sértő jellegétől". ${ }^{33}$ A 95/2008. (VII. 3.) AB határozat azzal érvel, hogy ,az alkotmányos demokrácia nem fojtja el a szélsőséges hangokat pusztán azok tartalma miatt". ${ }^{34}$ A 7/2014. (III. 7.) AB határozat megfogalmazásában az egyéni véleménynyilvánítás joga elképzelhetetlen anélkül, hogy „bárki szabadon, tartalmi kötöttségek nélkül közölhesse másokkal nézeteit, gondolatait", ${ }^{35}$ míg a 13/2014. (IV. 18.) AB határozat a közéleti véleménynyilvánítás körében szögezi le, hogy annak alkotmányos lehetősége tartalomtól függetlenül illeti meg a politikai közösség valamennyi tagját. ${ }^{36}$ A sajtószabadság körében pedig például a 19/2014. (V. 30.) AB határozat összegzi a korábbi hivatkozásokat akként, hogy „,[a] sajtószabadság védelmi köre független a vélemény tartalmától; nem is a vélemény tartalmát védi, hanem a vélemények közlésének folyamatát és eszközeit”. ${ }^{37}$

Mindezek a példák jól mutatják, hogy a korlátozások tartalmi szempontú értékelése a magyar doktrína markáns eleme. A döntések és érvelések láncolatnak

\footnotetext{
31 30/1992. (V. 26.) AB határozat, Indokolás V.3., ABH 1992, 167, 179.

${ }^{32}$ A szó szerinti hivatkozás példái többek között: 36/1994. (VI. 24.) AB határozat, 18/2004. (V. 25.) AB határozat, 75/2008. (V. 29.) AB határozat, 95/2008. (VII. 3.) AB határozat, 96/2008. (VII. 3.) AB határozat

${ }^{33}$ 57/2001. (XII. 5.) AB határozat, Indokolás II.6., ABH 2001, 484, 492.

${ }^{34}$ 95/2008. (VII. 3.) AB határozat, Indokolás III.3.4., ABH 2008, 782, 789.

35 7/2014. (III. 7.) AB határozat, Indokolás [39]

${ }^{36}$ 13/2014. (IV. 18.) AB határozat, Indokolás [25]

${ }^{37}$ 19/2014. (V. 30.) AB határozat, Indokolás [55]
} 
leghangsúlyosabb pontja e tekintetben a külső korlát megkövetelése a szólás- és sajtószabadság korlátozásakor. A hazai gyakorlatban a tartalomalapú és a tartalomsemleges korlátozások elkülönítésének módszere ezek szerint a külső korlát azonosítása: alkotmányosan azonosítható külső korlát esetén igen, ennek hiányában azonban nem igazolható a véleményszabadság megszorítása. A tartalomszempontú vizsgálat hazai relevanciájának értékeléséhez tehát először is annak kell utánajárnunk, hogy mit is takar számunkra a „külső korlát” terminusa.

\subsection{Tartalomtól valóban független korlátok}

A magyar doktrína tisztázását mindenekelött érdemes azzal kezdenünk, hogy mit nem takar ez a terminus. Korábbi elméleti áttekintésünk alapján be kell ugyanis látnunk, hogy a „mi tartalomsemlegességünk” jelentős része a tartalmi megközelítés fellegvárának számító tengerentúlon világosan tartalmi korlátozásnak minősülne. A külső korlát keresése a magyar joggyakorlat nagy jelentőségü ügyeiben sokszor eleve abban a körben vetődik fel, amit az amerikai szólásszabadság diskurzus konszenzusa kérdés nélkül tartalmi alapú beavatkozásként kezel. Míg nálunk - ahogy említettük és mindjárt elemezzük is - a gyülöletre uszításnak a szólás belátható következményeire fókuszáló mércéje a külső korlát iskolapéldája, addig az amerikai joggyakorlat még szigorúbb clear and present danger tesztje az egyébként tiltott tartalomalapú beavatkozások alkotmányos kivétele. ${ }^{38}$ Nemcsak arról van szó, hogy ezek a tesztek Ely szemléltető játékába belemenve - értelemszerüen a beszélő nyelvét értő hallgatóság esetén lépnek csak müködésbe, hanem arról, hogy nyilvánvalóan nem függetlenek a szólás kommunikatív hatásától, amit már a teoretikusok döntő többsége a tartalomalapúság legfontosabb ismérvének tart. A felvázolt értelmezési keretek tehát először is annak belátásához vezetik a magyar gyakorlat elemzőjét, hogy a külső korlát sok esetben nem a szólás tartalmától vagy kommunikatív hatásától függetlenül megragadható mércét jelent. Amikor a hazai doktrína a véleménynyilvánításnak egyfelől belső/tartalmi, másfelől külső/tartalomsemleges korlátozását különíti el egymástól, akkor valójában más szempontok körültekintő vizsgálatára szólít fel.

\footnotetext{
${ }^{38}$ A clear and present danger tesztet a szólásszabadság kézikönyvek is tartalomalapú korlátozásként tárgyalják. Vö. pl. STONE - SEIDMAN - SUNSTEIN - TUSHNET - KARLAN: The First Amendment (Fifth Edition). New York, Wolters Kluwer, 2016
} 
Mindebből persze nem következik, hogy a külső korlát fogalma ne foglalná magában mindenekelőtt a szólás tartalmától valóban független, arra nem utaló megszorításokat. A magyar gyakorlat vizsgálata azonban erre a körre kevésbé tereli a figyelmünket, mivel az Alkotmánybíróság elé alapvetően nem ilyen jellegü ügyekkel fordultak az indítványozók, így a külső korlát fogalma érdekes módon nagyobb figyelmet kapott ott, ahol annak értelmezése lényegesen komolyabb fejtörést okoz. Találunk mindazonáltal két fontos határozatot, amely számunkra most elegendő példája lehet a tartalomra valóban nem utaló korlátozásoknak.

Bár e dolgozat a szólásszabadság doktrínáját szűkebb értelemben dolgozza föl, és szándékosan nem foglalkozik a véleményszabadság mint anyajog körébe vonható többi kommunikációs jog elemzésével, e helyütt most mégis kivételt tehetünk a gyülekezési jog javára. A 75/2008. (V. 29.) AB határozat ugyanis a gyülekezési törvény alkotmányossági vizsgálatakor olyannyira szorosan hívta fel a szólásszabadság téziseit, hogy a benne foglalt érvelés mindenképp jelentőséggel bír most számunkra. Az Alkotmánybíróság - többek között - a törvénynek azokat a rendelkezéseit vizsgálta, amelyek a köztéri gyülekezések előzetes bejelentési kötelezettségét írták elö, lehetővé téve a rendőrség számára a rendezvény megtiltását, ha megtartása a népképviseleti szervek vagy a bíróságok zavartalan működését súlyosan veszélyeztetné, illetőleg a közlekedés rendjének aránytalan sérelmével járna. ${ }^{39} \mathrm{~A}$ testület egy korábbi döntését ${ }^{40}$ megerősítve a bejelentési kötelezettségnek ezt a formáját - mint a rendőrség közrendvédelmi feladatellátása szempontjából szükséges, külső korlátokat felállító megoldást - alkotmányosnak találta. Az indokolás központi tétele szerint a gyülekezések előzetes bejelentésének törvényben foglalt rendszere a tartalmi semlegesség követelményén nyugszik, és a hatóságok részéről nem vehetők figyelembe a rendezvényen megjelenő közlés tartalmára vonatkozó megfontolások. ${ }^{41}$ Tekintettel arra, hogy mind a népképviseleti szervek vagy a bíróságok müködésére, mind a közlekedés rendjére utaló fordulat teljes mértékben nélkülözi a gyülekezésen elhangzó véleménynyilvánítások tartalmára vagy hatására vonatkozó szempontokat, a szóban forgó korlátozás a tartalomtól független külső korlát egyértelmű példája. Az Alkotmánybíróság később is következetes maradt a gyülekezési törvény passzusait érintő értelmezéséhez, és a 14/2016. (VII. 18.) AB határozatban az ügy érdemét

\footnotetext{
${ }^{39}$ Gytv. 6. § és $8 . \S(1)$ bek.

40 55/2001. (XI. 29.) AB határozat

41 75/2008. (V. 29.) AB határozat, Indokolás IV.5.2., ABH 2008, 651, 667.
} 
tekintve a korábbi ösvényen haladva semmisítette meg az előzetes tiltó okokat kibővítő bírósági döntést.

Bár az alkotmánybírák érvelése a másik példánkban nem érintette a tartalomsemlegesség kérdését, mégis érdekes szempontokat tárhatunk majd föl a 3208/2013. (XI. 18.) AB határozattal elbírált ügyből. Az indítványozók által támadott szabályozás a közlekedésbiztonság javítása érdekében módosította a köztéri hirdetőtáblák elhelyezésével kapcsolatos szabályokat. A törvénymódosítás ${ }^{42}$ rendelkezései között tipikusan olyan elöírásokat találunk, amelyek a reklámhordozókra kihelyezett üzenettől függetlenül, tartalmi utalás nélkül szükítik a kommunikáció ezen csatornáját: a jogalkotó (1) kifejezetten megtiltotta a reklámok elhelyezését az út mütárgyán, tartozékán, közvilágítási-, villany- és telefonoszlopon, és (2) a lakott területeken kívüli útszakaszokra vonatkozó kivételeket bizonyos szempontból szükítette: korábban az úttól bizonyos távolságon kívül lehetőség volt bármilyen reklámtáblát kihelyezni, a módosítás után ez a kivétel csak a $4 \mathrm{~m}^{2}-\mathrm{t}$ meg nem haladó reklámtáblákra vonatkozott. Az Alkotmánybíróság határozata az ügy szólásszabadságszempontú vizsgálatát akként végezte el, hogy a módosítást kizárólag reklámozást érintő szabályként azonosította. Korábban már amellett érveltem, hogy a testületnek ez az értékelése alkalmatlan arra, hogy az ügyet a mérvadó szempontok közé helyezze, mivel ahhoz arra van szükség, hogy észrevegyük: a szóban forgó szabályozás a reklámoknál lényegesen szélesebb körben, így például a választási kampányolást is érintve szükítette a kommunikálás lehetőségét. Ha viszont ez utóbbi érvek mentén tekintünk az ügyre, akkor az itt vizsgált szabályozásban az utóbbi évek egyik újabb, a közlésekre a bennük foglalt üzenettől függetlenül vonatkozó tartalomsemleges korlátozás példáját azonosíthatjuk. Ezt annál inkább érdemes megtennünk, mivel a későbbiekben a tartalomközpontú megközelítés szerepének fontos ismérveit bonthatjuk majd ki ebből az ügyből.

\subsection{A szólás tartalma és módja}

Sajátossága és jelentősége miatt érdemes külön tárgyalni a magyar doktrínának azt a jellemző kísérletét, amely a szólásszabadság egyes korlátozásait azon az alapon

\footnotetext{
${ }^{42}$ Az egyes közlekedési tárgyú törvények módosításáról szóló 2010. évi CLXXII. törvény
} 
tekinti tartalomsemlegesnek, hogy azok csupán a vélemény formájára, módjára vonatkoznak. A közlések módjára vonatkozó korlátozások elkülönítése és enyhébb megítélése persze nem csupán hazai találmány, az amerikai Legfelső Bíróság esetjogában például az 1940-es évektől kezdve ${ }^{43}$ jelen van a szólások idejére, helyére és módjára (time, place and manner) vonatkozó elöírások kategóriája mint a tartalomsemleges megkötések fő csoportja. Az Alkotmánybíróság gyakorlatában ugyanakkor ez a kísérlet rendkívül visszás eredményre vezetett.

A szólásszabadság módjára, formájára vonatkozó korlátozások abban a szükebb körben, ahol a közlések tartalmára való hivatkozás nélkül jelennek meg, valóban alkalmasak arra, hogy megkülönböztessük őket a tartalomalapú beavatkozásoktól. ${ }^{44}$ Ebben a körben a véleménynyilvánítás módja a közlés eszközeként, csatornájaként, közvetítő közegeként értelmeződik. Ilyen korlátozások a tartalomfüggetlen beavatkozás fent említett esetei, a gyülekezések közlekedéstől függő helyszínét vagy a köztéri hirdetés fizikai hordozóit érintő szabályok, valamint világos határok rajzolhatók föl a megszólalások kommunikációs platformok szerint különböző egyes módjai (például utcai szónok vs. országos televíziós csatorna) között. További példákkal élve ebbe a körbe tartozhatnak a lakóövezeti csend tiszteletben tartására szólító szabályok vagy a közterületek tisztaságát óvó rendelkezések. A magyar gyakorlat azonban jellemzően ezen a körön kívül hívja fel a véleménynyilvánítás módjának megkülönböztető szempontját, a közlés stílusát, kifejezésmódját értve alatta.

A 33/1998. (VI. 25.) AB határozat Debrecen város önkormányzata szervezeti és müködési szabályzatának azt a rendelkezését vizsgálta, mely szerint a közgyülés rendbírsággal sújthatja azt a tagját, aki a közgyülési ülésen másokat sértő, illetve a testülethez méltatlan, nem illő kifejezést használ. A testület az érvelése alapjaként szögezte le, hogy a vizsgált esetben határozott különbséget kell tenni a véleménynyilvánítás szabadsága és a véleménynyilvánítás megjelenítésének formája, módja között. Míg a véleménynyilvánítás szabadsága fokozott alkotmányos védelmet élvez, addig a vélemény külső megjelenítésének formájával, módjával kapcsolatban a közgyülésnek mint autonóm közösségnek jogában áll olyan korlátozó rendelkezéseket alkotni, amelyek garantálhatják a testület zavartalan müködését. Az Alkotmánybíróság

\footnotetext{
${ }^{43}$ Cantwell v. Connecticut 310 U.S. 296, 304 (1940), Cox v. New Hampsire 312 U.S. 569, 575 (1941)

${ }^{44} \mathrm{Az}$ amerikai gyakorlatban végül a Clark v. Community for Creative Non-Violence ügy fogalmazta meg a máig használatos tesztet, amely szerint ahhoz, hogy egy korlátozás ebbe a körbe kerüljön, mindenekelött arra van szükség, hogy a tartalomra való utalás nélkül igazolható legyen. 468 U.S. 288, 293 (1984)
} 
szerint a másokat sértő, illetve a testülethez méltatlan, hozzá nem illő kifejezések kizárása ilyen, az érdemi testületi müködést biztosító rendelkezés. ${ }^{45}$ Az elhatárolás nehézségét maga is érzékelve az Alkotmánybíróság mindehhez végül hozzátette, hogy bár határozata a véleménynyilvánítás jogának, valamint e jog megjelenítési formájának és módjának elkülönítésén alapszik, ez nem jelenti azt, hogy a kettő között ne lenne összefüggés: „[v]égletes esetben ugyanis a véleménynyilvánítás módjának meghatározása közvetlenül befolyásolhatja a véleménynyilvánításhoz való emberi jog érvényesülését is”. Amennyiben ugyanis a helyi szabályozás „a véleménynyilvánítási jog kifejezésének módját indokolatlanul szigorú keretek között tartja", akkor közvetlenül akadályává válna a szabad véleménynyilvánítási jog érvényesülésének is. 46

Ugyanezzel az érveléssel élt az Alkotmánybíróság az országgyülési fegyelmi szabályok felülvizsgálatakor. A 3206/2013. (XI. 18.) és a 3207/2013. (XI. 18.) AB határozatok a Házszabálynak azokat a rendelkezéseit vizsgálták, amelyek mind a bizottsági, mind a plenáris ülés tekintetében fegyelmi intézkedéseket helyeztek kilátásba, ha a felszólaló képviselő az Országgyülés tekintélyét kirívóan sértő kifejezést használ. A testület mindkét határozat indokolásának vonatkozó részében a 15 évvel korábban kifejtetteket erösítette meg, kifejtve, hogy ebben az esetben is a vélemény külső megjelenítési formájának, módjának korlátozásáról van szó, amelynek során a Házszabály az érdemi testületi müködést biztosító határokat jelölte ki. ${ }^{47}$

Érdemes megemlíteni, hogy az Alkotmánybíróság érvelése a véleménynyilvánítás módját, formáját ezzel az Emberi Jogok Európai Bíróságának esetjogában is megjelenő értelemben használja: a strasbourgi bíróság a blaszfémiával összefüggő gyakorlatában hasonló érveknek tulajdonított jelentőséget. Az Otto-Preminger-Institut kontra Ausztria ügy ítéletének később is többször idézett tétele szerint bár a vallásos emberek kötelesek eltürni a meggyőződésüket ért kritikákat és mások ellenséges nézeteit, a hitbeli meggyőződések elutasításának bizonyos módjai (the manner in which religious beliefs are opposed) mégis felvethetik az állam felelősségét a vallásszabadsága joga békés élvezetének biztosítására. ${ }^{48}$

\footnotetext{
${ }^{45}$ A testült a szintén kifogásolt „alaptalan” jelzőt már parttalannak érezte és megsemmisítette.

46 33/1998. (VI. 25.) AB határozat, Indokolás III.3., ABH 1998, 256, 261.

${ }^{47}$ 3206/2013. (XI. 18.) AB határozat, Indokolás [24]-[26], illetve 3207/2013. (XI. 18.) AB határozat Indokolás [22]-[24]

${ }^{48}$ Otto-Preminger-Institut kontra Ausztria (13470/87), 1994. szeptember 20-i ítélet, 49. bekezdés
} 
Az Alkotmánybíróság (és az EJEB) szóban forgó érvelése lényegében azt állítja, hogy bármilyen tartalmú, a testületek politikai vitájához kötődő (avagy az istenhittel vagy a vallásokkal kritikus vagy ellenséges) vélemény kifejthető lenne, ha azt tisztességes, nem sértő, vitaképes stílusban fogalmaznák meg. A döntések érdemét e helyütt nem érintve azonban világosan látnunk kell, hogy ez az érvelés, amely a jelen esetben a véleménynyilvánítás módjában tartalomsemleges korlátozást igyekszik azonosítani, követhetetlenül összekuszálja a tartalmi és a nem-tartalmi elemek értékelését. Az Alkotmánybíróság ezekben a határozatokban a tartalmi szempontú értékelést valójában nem létező különbségtételre alapozza. Míg a véleménynyilvánítás módja mint a közlés eszköze, csatornája, közvetítő közege elválasztható a szólás tartalmától, addig ugyanez már nem tehető meg vele, ha a közlés stílusát, kifejezésmódját értjük alatta. A testület érvelése értelemszerüen adottnak veszi, hogy a véleménynyilvánítás tartalma és stílusa elválasztható egymástól és külön kezelhető. Úgy látja, hogy ha csak a formát, a kifejezésmódot korlátozzuk, akkor a tartalom sértetlen maradhat. A tartalom és a stílus közti különbségtétel hangsúlyozása azt feltételezi, hogy minden állítást lényegi jelentésváltozás nélkül ki lehet fejezni sértő vagy nem sértő formában is. Ez azonban nem általánosítható, sőt: jellemzően a vélemény tartalma és a kifejezés stílusa egészen szorosan, szétválaszthatatlanul összekapcsolódik, és együtt adja ki magát a véleménynyilvánítást. Bár kicsit sántít a hasonlat, mégis mondható, hogy a zeneművészet szabadságával kapcsolatban is nehéz lenne védeni azt az állítást, mely szerint mindenkinek szabad zenét szereznie, de csak úgy, ahogy Mozart vagy Bartók tette, mert a többi bántja a fülünket. A szólások széles köre nem azért fogalmaz élesen, kemény vagy akár felháborító stílusban, hogy másokat sértegessen, hanem azért, hogy hangulati árnyalataival együtt hüen fejezze ki a véleményalkotó nézeteit. A közlések stílusa nem is értelmezhető másként, mint a tartalomra reflektáló kulturális minták terméke, így szétválasztásuk logikailag nem védhető. ${ }^{49}$

Az előttünk fekvő példák mindennél jobban alátámasztják kételyünket: mi más vonatkozhatna a véleménynyilvánítás tartalmára, ha nem a „sértő, méltatlan, nem illő kifejezések" használata? Mindebből egyelöre egyetlen, nem az ügyek érdemére vonatkozó következtetés adódik: a szólásszabadság tartalmát érintő korlátozások

\footnotetext{
49 Robert C. Post: Cultural Heterogeneity and Law: Pornography, Blasphemy, and the First
} Amendment. 76 California Law Review 297 1988. 309. 
beható vizsgálata nem kerülhető meg azzal, hogy a közlés stílusának, kifejezésmódjának szabályozását tartalomsemleges előírásoknak próbáljuk beállítani.

Tanulságos visszaidéznünk, hogy az általam bírált logika némiképp visszaköszön ugyan Stone javaslatában, mely szerint a trágárság (profanity) korlátozását elegendő enyhébb mércével mérni, azonban fontos különbségek azonosíthatók. Egyrészt Stone elismeri, hogy ezek a szabályok a közlés tartalmára vonatkoznak, ugyanakkor a másokat zavaró kommunikáció olyan formáját érintik, amely sokkal inkább hasonlít például a zajterheléshez. Másrészt felhívja a figyelmet arra, hogy a trágár módon kifejezett üzenet fontos érzelmi töltetet hordozhat, továbbá korlátozása egyeseket jobban érint, amely kockázatokat a mérlegelés során mindenképp értékelni kell. ${ }^{50}$

Összességében mindenképpen leszögezhetjük, hogy a véleménynyilvánításnak és módjának megkülönböztetésén alapuló módszer abban a formájában, ahogy eddig a magyar doktrínában szerephez jutott, nem alkalmas a szólásszabadság-vizsgálat releváns szempontjainak igazolható megragadására, és különösen hazug eredményre vezet, ha a tartalomszempontú megközelítés releváns elemeként hivatkoznak rá.

\subsection{Tartalomtól nem független külső korlátok}

Ahogy korábban már említettük, a magyar doktrína tartalmi megközelítést preferáló kategóriája, vagyis a külső korlát fogalma már születése pillanatában a közlések tartalmától valójában nem független korlátozásokra utalt. A 30/1992. (V. 26.) $A B$ határozat a gyülöletre uszításnál alkotmányos külső korlátot azonosított, ugyanakkor a szólásszabadság irodalom konszenzusát a hátunk mögött tudva mondhatjuk, hogy a clear and present danger típusú tesztek a tartalomalapú megszorítások legszélesebb körben elfogadott példái. Ezek a formulák ugyanis nyilvánvalóan nem a közlés tartalmától függetlenül lépnek működésbe, hiszen éppen az általuk kiváltott hatás vizsgálata a lényegük, márpedig egy kommunikatív aktus hatása értékelhetetlen a kommunikáció tartalmára tekintet nélkül. Ilyen tartalmi szempont például az uszítás magyar mércéje esetében, hogy a szélsőséges beszédnek az érzelmekre kell hatnia. Az érzelmekre ható véleménynyilvánítás - szemben az értelem meggyőzését célzóval - az ösztönökre, érzelmekre alapoz, mozgósít. Súlyosabb magatartás, mint az, amelyik

\footnotetext{
${ }^{50}$ STONE (3. 1j.) 243.
} 
mások gondolkodását mégoly sulykoló módon, érvek sorozatával igyekszik befolyásolni, és ezzel nyilvánvalóan érzelmi hatást is kiválthat. Az uszítás kifejezetten zsigeri indulatokat gerjeszt, és így az erőszak érzelmi előkészítésének minősül. Ezeknek a szempontoknak a célja egyértelmüen szólásszabadság-barát, hiszen a beavatkozás körét hivatottak szükíteni, ám ettől még kétségkívül tartalmi természetűek.

A gyülöletre uszítás elemzésénél azonban eleinte még kínálkozott egy értelmezési lehetőség, amely a releváns tesztet a tartalmi szempontoktól távolítva beláthatóvá teszi a korlát „külső” jellegét. Az uszító beszéd veszélyes következményére fókuszáló mérce - a rémhírterjesztésnek a 18/2000. (VI. 6.) AB határozatban kibontott mércéjével együtt - az egyedi kommunikatív szituáció konkrét külső tényezőire tereli a mérlegelést végző figyelmét. A szólás egyes tartalmi összetevői mellett a jogi értékelés hangsúlya azon van, hogy a közlés elhangzásakor ott és akkor milyen tényleges kockázatok azonosíthatók. Elöző fejezetünkre utalva mondhatjuk: a tartalomtól való eltávolodást segíti, hogy ezekben az esetekben a szólás ártalma a külsőleg megragadható következményekben rejlik. Az uszítás tesztje ezzel eléri, hogy a mérlegelés nem önmagában a szóban forgó közlés értéktartalmán, szélsőségességén fordul meg, hanem a beszéd ténylegesen veszélyes körülményein. Érdekes módon ezt az összefüggést a legtalálóbb módon az a 165/2011. (XII. 21.) AB határozat említi meg, amely egyébként, médiajogi elöírásokat vizsgáló határozat lévén, jellemzően éppen más logikában müködő mércéket alkalmaz. Az indokolás a szólás- és sajtószabadságra vonatkozó alkotmánybírósági gyakorlatot összefoglaló egyik részében akként összegez, hogy a sajtószabadság korlátozása elsősorban nem tartalmi, hanem következmény-szempontú vizsgálatot igényel, ami a szavak tartalma helyett a szándékoltan kiváltott hatásra fókuszál. ${ }^{51}$

Ezt a kezdetben még adódó értelmezést azonban a későbbi gyakorlat nem követte, vagyis a külső korlát fogalmát a szólás konkretizálható veszélyes következményein jócskán túlterjeszkedő területre is vonatkoztatta. Ez utóbbi iránynak a gyökerei egyébként magában a 30/1992. (V. 26.) AB határozatban megtalálhatók, amely a gyalázkodás alkotmányellenessége mellett érvelve a külső korlát hiányát abban látja, hogy ott nem azonosítható vagy legalábbis rendkívül bizonytalan a más jog sérelme -

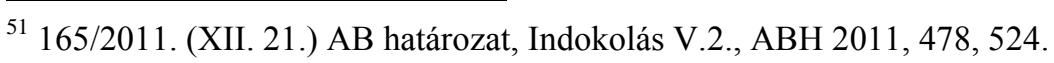


szemben az uszítással, ahol egyéni jogok kerülnek veszélybe. ${ }^{52}$ Ezt követően a külső korlát felhívásának egyik markáns vonala lett a magyar gyakorlatban a személyiségvédelem körébe sorolható jogok ilyenként való megragadása. A közszereplők bírálhatóságával kapcsolatos 36/1994. (VI. 24.) AB határozat indokolása szerint bár a szólásszabadság az értékítéletekre az egyéni vélemény tartalmától (értékétől, igazságától, racionalitásától) függetlenül terjed ki, az emberi méltóság, a becsület, a jó hírnév az értékítéleteknek is külső korlátja lehet. ${ }^{53}$ Más kérdés, hogy a személyiségvédelem tesztjei eltérőek a közügyek vitájában és azon kívül, de módszertani szempontból a véleményszabadság külső korlátjaiként funkcionálnak. A 33/1998. (VI. 25.) AB határozat mindezek után már a doktrína tételeként utal vissza arra, hogy a véleménynyilvánítás alapjoga - ahogy láttuk: ez esetben megkülönböztetve annak módjától - fokozott védelmet élvez, így azt „,csak az emberi méltósághoz, a becsülethez és a jó hírnévhez való jogok védelme - mint külső korlátok - korlátozhatják". 54

Később a hazai gyakorlat a külső korlát fogalmát tovább szélesítette. Nemcsak arról van szó, hogy az évek során születtek olyan döntések, amelyek a külső következmények helyett egyre inkább „,bennerejlő sérelmekre” reagáló szabályokat hagytak jóvá, ${ }^{55}$ hanem arról is, hogy az Alkotmánybíróság magát a formulát is ezekhez az értelmezésekhez kezdte igazítani. A 33/1998. (VI. 25.) AB határozat logikáját és kulcsmondatait egyébként hüen követő 3206/2013. (XI. 18.) és 3207/2013. (XI. 18.) $A B$ határozatok a külső korlátot már kibővített tartalommal hívják fel, az emberi méltósághoz, a becsülethez és a jó hírnévhez való jog védelme mellett kiterjesztve a magyar nemzet, a nemzeti, etnikai, faji vagy vallási közösségek méltóságának védelmére is. ${ }^{56}$ A már hivatkozott ,gyülekezéses" 14/2016. (VII. 18.) AB határozat a közösségek méltósága körében fontos pontosítást téve a külső korlátot a gyülöletkeltésben ragadja meg, ugyanakkor újabb elemként utal az alkotmányos alapértékek védelmére. Az esetről esetre mérlegelendő kérdés eszerint az, hogy a gyülekezés megvalósít-e gyülöletkeltést, illetve hogy ,,a demokratikus jogállam, azaz a

\footnotetext{
52 30/1992. (V. 26.) AB határozat, Indokolás V.3., ABH 1992, 167, 179.

53 36/1994. (VI. 24.) AB határozat, Indokolás III.2., ABH 1994, 219, 230.

54 33/1998. (VI. 25.) AB határozat, Indokolás III.3., ABH 1998, 256, 260.

${ }^{55}$ Lásd az előző fejezetet

56 3206/2013. (XI. 18.) AB határozat, Indokolás [25], illetve 3207/2013. (XI. 18.) AB határozat, Indokolás [23]
} 
fennálló alkotmányos rend, az államberendezkedés alapvető értékei ellen" irányul-e. ${ }^{57}$ Említésre méltó, hogy utóbbi körben az Alkotmánybíróság az Emberi Jogok Európai Bíróságának arra a jogértelmezésére is támaszkodik, amely szerint a joggal való visszaélés tilalma alapján a szólásszabadságra sem hivatkozhat az, akinek célja diktatúra bevezetése és az Egyezményben biztosított jogok megsemmisítése.

Mindezek után végképp egyértelmű következtetést vonhatunk le: a személyiségi jogok védelme mellett a közösségek méltósága vagy az alkotmányos alapértékek ellen irányuló közlésekkel szemben is bevett módon használható kategória nem lehet alkalmas arra, hogy a tartalomalapú és a tartalomsemleges korlátozások szétválasztásának módszere legyen. A külső korlát tesztje, amely a hazai judikatúrában sosem volt mentes a beszéd egyes tartalmi jellemzőinek értékelésétől, idővel egyre inkább tartalmi szóláskorlátoknak is gyüjtőfogalmává vált. Fel kell tennünk a kérdést: vessük-e hát el teljesen? Értelmetlen-e az általa megidézett tartalomközpontú értékelés a szólásszabadság magyar koncepciójában? Az alábbiakban amellett érvelek, hogy nem, sőt a külső korlát fogalmának súlyos belső ellentmondásai sajátos módon még segítségünkre is lehetnek az összetettebb valóság magyarázatában. Így ugyanis egyszerre mondhatjuk, hogy egyrészt a tartalomsemlegesség gondolatának felhívása megkerülhetetlenné teszi számunkra a tartalmi megközelítés legfontosabb szempontjait, másrészt nem vagyunk (sosem voltunk) bezárva e szempontok közé, ami viszont növelheti érzékenységünket további releváns körülmények iránt.

\section{A tartalomsemlegesség érvényes tételeinek tisztázása}

A külső korlátot mint a véleményszabadság korlátozásának speciális központi kategóriáját érintő vizsgálódásunk arra vezetett, hogy a gyakorlat idővel ennek keretébe helyezte a mások személyiségi jogai, egyes társadalmi közösségek méltósága, illetve az alkotmányos alapértékek védelme érdekében bevezetett egyes szóláskorlátokat is. E kategóriák szélességétől megriadva nemcsak azt vonhatnánk le következtetésként, hogy a külső korlát valójában nem a tartalomalapú és tartalomsemleges megszorítások elkülönítésének precíz tesztje, hanem akár azt is, hogy az nem más, mint az alapjogkorlátozás általános módszerének a szólásszabadság

\footnotetext{
${ }^{57}$ 14/2016. (VII. 18.) AB határozat, Indokolás [38]-[40] és [44]
} 
doktrínán belül érdekesen megfogalmazott formulája, ami nélkülözi a markáns speciális szempontokat. Amellett érvelek, hogy ez nem így van, és a tartalmi megközelítés felidézésével középpontba helyezett egyes szempontok nem törtek össze a külső korlát ellentmondásainak súlya alatt. E tényezők megragadása mellett ugyanakkor azt is tisztáznunk kell, mely pontokon érdemes meghaladnunk a szigorú tartalmi vizsgálatot. Az alábbiakban összességében arra teszek kísérletet, hogy a korábban vizsgált határozatok tükrében számba vegyem: a magyar doktrínában milyen tételek bonthatók ki a tartalmi alapú megközelítés problémaköréböl, mely megfontolások tekintendők a tartalomsemlegesség ma is érvényes téziseinek.

Először is azzal kell kezdenünk, hogy a fenti, a szólásszabadság nyújtotta védelmet érintő kihívások semmit nem vonnak le annak a tételnek az erejéből, hogy a véleménynyilvánítás jogának a hatálya a nyilvános társadalmi párbeszédben résztvevő közlésekre tartalmuktól függetlenül terjed ki. A magyar doktrínában a hatály alá vonás kérdése nem tehető függővé a konkrét megszólalás tartalmi elemeitől. Minden szólás, amely része a társadalmi diskurzusnak, a szólásszabadság hatálya alá tartozik, és alkotmányjogi jelentőségét, védettségét ennek figyelembevételével kell megtalálni. E tekintetben pontosan fogalmaz a 30/1992. (V . 26.) AB határozat indokolása, amikor leszögezi, hogy a véleménynyilvánítás szabadsága nem annak tartalmára vonatkozik. ${ }^{58}$ Egy későbbi döntéshez füzött párhuzamos indokolás a tartalmi megközelítést terhelő ellentmondásokat éppen azzal próbálta feloldani, hogy a tartalomsemlegesség csupán az „alapjogi tényállás védelmi körére” - e dolgozat fogalmi készletében: hatályára értendő, nem pedig a korlátozás alkotmányosságának megítélésére. ${ }^{59}$ Bár mi a korlátozás mérlegelésére is fontos szempontokat látunk levezethetőnek a külső korlát követelményéből, kétségtelen, hogy a tartalomsemlegesség gondolatának a szólásszabadság hatálya esetében kell legkövetkezetesebben érvényesülnie. A magyar doktrína e tekintetben határozottan szemben áll a korábban részletesebben elemzett 3206/2013. (XI. 18.) AB határozat érvelésével, amely a társadalmi csoportokat kirívóan sértő kifejezések használatának kérdését annyival intézte el, hogy azokra a véleménynyilvánítás alaptörvényi védelme eleve nem terjed ki. A közösségeket sértő beszéd, a tágabb értelemben vett gyülöletbeszéd a szólásszabadság hatálya alá tartozik, valamennyi megnyilvánulásával együtt. A hatály alá vonás ugyanis nem múlik máson, minthogy a kommunikációnak az az esetköre, típusa, amelybe tartozik, kétségkívül

\footnotetext{
58 30/1992. (V. 26.) AB határozat, Indokolás V.3., ABH 1992, 167, 179.

59 4/2013. (II. 21.) AB határozat, Bragyova András párhuzamos indokolása, Indokolás [83]
} 
kapcsolatban áll a szólásszabadság alkotmányos értékeivel. A társadalmi csoportokat érintő közéleti szólások mindig kapcsolódnak a nyilvános politikai diskurzushoz, sőt kifejezetten a közvélemény formálásának igényével lépnek föl.

Másodszor, ehhez szorosan kötődve, de már a szólásszabadság nyújtotta védelemre fókuszálva fogalmazhatjuk meg, hogy a magyar doktrína a külső korlátra való kitartó utalással őrzi azt a szemléletet, amely a vélemények korlátozásának indokát nem önmagában a tartalomban, hanem a közlés kontextusában keresi. Ez a kijelentés kitünően megfér azzal a ténnyel, hogy a hazai gyakorlat nem helyezkedik a tartalmi alapú megközelítés szigorú álláspontjára, és e megközelítés számunkra is mérvadó és érvényes üzenetét fogalmazza meg: bár a szólásokat korlátozó rendelkezések nem buknak el az alkotmányosság próbáján pusztán azért, mert tartalmi összetevőket is értékelnek, az életben (érvényben) maradáshoz a közlés további körülményeibe kell kapaszkodniuk. A véleménynyilvánítás megszorítása nem hivatkozhat önmagában valamely közlés tartalmának értéktelenségére, hamisságára, elfogadhatatlanságára. Bár az Alkotmánybíróság többségi indokolásai ezt a tisztázást sosem tették meg kellő egyértelmüséggel, két alkotmánybírói vélemény velünk azonos összegzésre jutott. Az egyik szerint nincs olyan vélemény, amelynek közlése kontextusától függetlenül, pusztán tartalma alapján korlátozható lenne, vagyis a jogkorlátozás alkotmányossága minden esetben a körülmények összességétől függ. ${ }^{60}$ A másik rendkívül frappánsan mutat rá arra, hogy ,valahol, valamikor, valamilyen módon tartalmától függetlenül minden véleménynek kimondhatónak kell lennie - akkor is, ha a hely, mód, idő stb. korlátozható.",61

Ezt a logikát láthatjuk visszaköszönni például az audiovizuális médiatartalmak szabályozásánál. A számunkra legszemléletesebb példával élve: míg a gyalázkodás általános szankcionálását az Alkotmánybíróság 1992 óta következetesen megakadályozta, ugyanezen tartalom médiahatósági üldözését már alkotmányosnak ítélte. Az 1006/B/2001. AB határozat legitim célnak fogadta el annak megakadályozását, hogy „a rádió és a televízió a sértő, faji alapon elítélő, kirekesztésre, diszkriminációra felhívó gyűlölködők »hangerősítője« legyen”. A testület ez esetben már tartalmon túli körülményként támaszkodott arra a médiajogi érvre, hogy „a rádiós és televíziós müsorszolgáltatás véleményformáló hatása és a

\footnotetext{
${ }^{60}$ 14/2000. (V. 12.) AB határozat, Kukorelli István különvéleménye, ABH 2000, 108.

${ }^{61}$ 4/2013. (II. 21.) AB határozat, Bragyova András párhuzamos indokolása, Indokolás [83] (kiemelés az eredetiben)
} 
mozgóképek, hangok, élő tudósítások meggyőző ereje sokszorosa az egyéb információs társadalmi szolgáltatások gondolkodásra ható erejének". ${ }^{2}$

Az audiovizuális média eltérő szabályozása azonban csak az egyik legátfogóbb példája a kontextuális megközelítésnek, annak jelentősége a szólásszabadság egész hatályára kiterjed. Az Alkotmánybíróság ebből a szempontból is a tisztázás kínálkozó lehetőségét mulasztotta el, amikor a 4/2013. (II. 21.) AB határozatban a tiltott önkényuralmi jelképek használatát tiltó büntetőjogi rendelkezés megsemmisítésekor nem fejtette ki a véleményszabadság szempontjából releváns szempontokat. Ha megtette volna, akkor hangsúlyosabban szoríthatta volna a jogalkotót azoknak a helyzeteknek az üldözésére, amelyekben a demokratikus alapértékek tudatos gyengítéséről van szó.

Harmadszor, a külső korlát elvének doktrínában tartása arra is figyelmeztet bennünket, hogy ne keverjünk össze két jelentős mértékben különböző kérdést: egyfelől azt, hogy a magyar gyakorlat - az előző fejezetben vizsgált speciális sérelmek mentén - kivételes esetekben a véleménynyilvánítással közölt nézetre is tekintettel volt egyes határok megvonásakor, másfelől azt, hogy a tartalomsemlegesség követelményének leglényegesebb szabálya, a nézőpontok között szelektáló állami beavatkozás tilalma továbbra is a hazai doktrína egyik vezérelve. A magyar formula a vélemény érték- és igazságtartalma érinthetetlenségének hangsúlyozásával ezt teszi egyértelművé, és a tétel nem vesztette érvényét azzal, hogy a gyakorlat szük körben, kiemelt jelentőségü alkotmányos alapértékek védelmében kivételt engedett ez alól. Korábbi elméleti szempontjaink segítségével ezt az ellentmondást - a szigorú tartalmi megközelítést követő amerikai esetjog önellentmondásaihoz képest a siker reményével - megpróbálhatjuk feloldani. Láttuk, hogy a magyar koncepció kulcsfogalma, a külső korlát kategóriája nem a tartalomra utaló és a tartalomtól teljesen független korlátozásokat különíti el egymástól. Ennek tudatában mondhatjuk, hogy a hazai doktrína a tartalomsemlegességnek azt a felfogását jeleníti meg, amely elsődlegesen nem önmagában a tartalmat figyelembe vevő szabály jelentette kockázatra, hanem más veszélyre koncentrál. A magyar doktrínát viszonylag sikeresen magyarázhatjuk, ha az elméleti diskurzusnak ahhoz a vonalához csatlakozunk, amely szerint az alkotmányossági vizsgálat fókuszába nem is annyira a tartalmi érintettség kérdését, mint inkább a beavatkozó állam motivációját kell helyeznünk.

\footnotetext{
${ }^{62}$ 1006/B/2001. AB határozat, Indokolás III.5.2., ABH 2007, 1366, 1374.
} 
A tartalomsemlegesség szempontjához kötődően tehát, negyedszer, a magyar gyakorlat magyarázó elve lehet, hogy az mindenekelőtt a szólásszabadság korlátozásának motivációjára irányítja a figyelmünket. ${ }^{63}$ Nem önmagában annak van döntő jelentősége, hogy a jogalkotói beavatkozás érinti-e a közlések tartalmát, üzenetét vagy sem, hanem annak, hogy a beavatkozás mögött alkotmányosan védhető vagy védhetetlen indokok, szándékok húzódnak-e meg. Ez egyrészt érthetővé teszi, hogy a magyar gyakorlat külső korlátot azonosítva miért nem lát kivetnivalót az egyéni alanyi jogok védelmében történő beavatkozásokban (például a becsületsértésben), holott azok nyilvánvalóan tartalmi jellegű korlátok. Az előző fejezetben bemutatott módon a szólásszabadság doktrínája a konkrét személyekhez kötődő, éppen ezért megragadható sérelmekre tekint a legkisebb gyanakvással. Másrészt az egyéni jogokon túli területre is igaz, hogy ha a kérdést így tesszük fel, akkor a korábbi ellentmondások feloldhatóbbá válnak: egyfelől igaz, hogy a tartalmi korlátozások sokszor az államnak a demokratikus nyilvánosságot tudatosan torzító, így a szólásszabadság számára menthetetlen szándékára utalnak, másfelől elképzelhető, hogy néhány szüken értelmezett, a legalapvetőbb alkotmányos értékekre visszavezetett, politikai konszenzussal övezett esetben a motiváció igazolhatóbbá válik. Ha ezzel a szemmel tekintünk a legnagyobb kihívást jelentő olyan döntésekre, mint a nemzeti jelképek meggyalázásának, a tiltott önkényuralmi jelképek használatának vagy akár az önkényuralmi bűntettek tagadásának tilalmára, akkor talán érthetőbbé válik, hogy bár ezek sem makulátlanok a nézőpontsemlegesség szempontjából, más beavatkozásokhoz képest miért pont ezek nyertek igazolást a véleményszabadság doktrínájában. Ilyen rendkívüli körülmény híján azonban a nyilvánosság torzítására vagy megszorítására irányuló kormányzati szándék leleplezhető.

Ezt figyelhetjük meg az 1/2013. (I. 7.) AB határozatban, amely többek között annak a szabálynak az alkotmányosságát vizsgálta, mely szerint kampányidőszakban kizárólag a közszolgálati médiaszolgáltatásban tehető közzé politikai reklám. Tekintettel arra, hogy a rendelkezés a politikai kommunikáció egyik fontos eszközét éppen a társadalomhoz legszélesebb körben eljutó médiumok esetében szüntette volna meg, az Alkotmánybíróság tüzetesen vizsgálta, milyen célokat szolgálhat egy ilyen módosítás, és az ügy összes körülményének mérlegelését követően sorra kizárta azokat

\footnotetext{
${ }^{63}$ A motiváció alatt értett szempontok feltárása a magyar alapjogi dogmatika szerint a jogalkotói célkitüzések (a strasbourgi terminológiában a legitim cél) vizsgálata révén mindenképpen eleme az alkotmányossági felülvizsgálatnak.
} 
az érveket, amelyek a beavatkozást menthetővé tehették volna. ${ }^{64} \mathrm{~A}$ választói akarat zavartalan kinyilvánítását szolgáló kampánycsend körében például a testület figyelemmel volt arra, hogy a vizsgált törvény egyebekben éppen hogy megszünteti a kampánycsend intézményét, vagyis jelen esetben ennek a jogalkotói motivációnak az ereje radikálisan meggyengül. Ugyanilyen beszédes, ahogy a határozat indokolása azt az érvet utasítja el, hogy a korlátozás a kampányköltségek megfékezését, ezáltal a választások tisztaságát szolgálja. Az Alkotmánybíróság szerint ez esetben nem ez motiválhatta a törvényhozót, hiszen a többi kampányeszköz költségcsökkentő használatát egyáltalán nem szabályozta, és a kampányolás összköltségére nézve sem állapított meg új elöírásokat. Ezeknek az indokoknak a kizárását követően a kormányzat más, rejtett, a szólásszabadság számára védhetetlen motivációjának esélye radikálisan megnövekszik, amelynek fontos szerepe volt a vizsgált szabály alkotmányellenességének megállapításához vezető érvelésben. A védhetetlen motiváció jelenlétének gyanúját ebben az esetben az a szempont is erősíti, amelyet az alkotmánybírósági határozat indokolásához képest továbblépve már mi magunk füzhetünk hozzá a kérdéshez: a vizsgált szabályozás, bár valamennyi politikai reklámra egyaránt kiterjedt, nem tekinthető teljes mértékben nézőpontsemlegesnek, legalábbis ha a fogalmat az irodalomban kidolgozott szélesebb értelmében használjuk. Eszerint ugyanis a nézőpontalapú korlátozások elleni érvek bizonyos mértékben akkor is felhasználhatók, ha egy látszólag semleges szabály a nyilvánosságot valójában aránytalanul torzítja, vagyis bizonyos nézőpontokat vagy bizonyos megszólalókat egyértelműen hátrányosabb helyzetbe hoz. Meggyőződésem szerint a politikai reklámozás szabályozásánál komoly érvek szólnak amellett, hogy ilyen esettel állunk szemben. Az országot irányító, intézkedő kormányzat hangja - kiváltképp egy vele többségében nem ellenséges médiakörnyezetben - szükségszerüen hangosabban hallatszik a politikai diskurzusban, amely helyzeti előny ráadásul a kampányidőszakban tudatos kormányzati lépésekkel és kommunikációval különösen hatásosan aknázható ki. Ilyen környezetben a kormány leváltására törő politikai ellenzék nagyobb mértékben van rászorulva arra, hogy üzeneteit fizetett politikai hirdetések útján igyekezzen eljuttatni a választópolgárokhoz. E lehetőség radikális szükítése vagy elvesztése tehát az ő kampánykommunikációs lehetőségeit súlyosabban

\footnotetext{
${ }^{64}$ Annak ellenére, hogy az európai megközelítés alapvetően jóval több teret enged a kampányolás jogi kereteinek meghatározására, mint az amerikai alkotmányos gyakorlat. UDVARY Sándor: Citizens United - Nem európainak való vidék. A társaságok független részvétele a politikai kampányokban. In Medias Res 2012/2. 211-240.
} 
érinti, mint a mindennapi tájékoztatásban egyébként is főszerephez jutó kormányzatot. Még ha nem is állíthatjuk, hogy ez a helyzetelemzés mindig és mindenhol érvényes, annak kijelentésére bizonyosan vállalkozhatunk, hogy 2013-ban és Magyarországon az volt. Mivel pedig a védhető motivációk már kiestek, nagy az esélye a védhetetlennek: a politikai reklámozás lehetőségének radikális szükítése valójában az ellenzéki kampányolás hatékonyságának megakadályozására szolgáló intézkedés. ${ }^{65}$

Végül ötödször arról, ami a tartalomsemlegesség körében tett barangolásunk egyik legfontosabb következtetése: ha a korlátozás tartalmi érintettsége helyett annak motivációját helyezzük a középpontba, akkor a tartalmi megközelítés jelentette dichotómiából kilépve lehet és kell szigorú szólásszabadság-vizsgálatot folytatnunk. A motiváció vizsgálatához a tartalmi megközelítés fontos támogatás lehet, de semmiképp sem válhat kizárólagosan perdöntő módszerré. Magyarán szólva: a látszólag tökéletesen tartalomsemleges szabályozást is a legszigorúbb mércével kell megítélnünk, ha az állam mások elhallgattatására irányuló szándéka sejlik föl a körülményekből.

Már a politikai reklámozás korlátozásának előző példája is elénk tárt ide tartozó szempontokat, de még érdekesebben azonosíthatjuk őket egy olyan ügyön, amelyet korábban a tartalomtól valóban független beavatkozás példájaként hoztunk föl. A 3208/2013. (XI. 18.) AB határozatban vizsgált szabályozás a közlekedésbiztonság javítása érdekében módosította a köztéri hirdetőtáblák elhelyezésével kapcsolatos elöírásokat. Mint említettük, a törvénymódosítás szabályai között tipikusan olyan rendelkezéseket találunk, amelyek a reklámhordozókra kihelyezett üzenettől függetlenül, tartalmi utalás nélkül szükítik a kommunikáció ezen csatornáját (például reklámtábla kihelyezésének tilalma villanyoszlopon vagy bizonyos méretű hirdetőtáblák elhelyezésének szigorítása). Az Alkotmánybíróság a pusztán reklámkorlátozásnak tekintett szigorítást alkotmányosnak találta, tekintettel arra, hogy a közlekedés biztonságának növelése (az élet- és vagyonbiztonság védelmére tekintettel) elegendő indok a kereskedelmi szólás szabadságának a korlátozására, és a jogalkotó arányos megoldásra törekedett akkor, amikor csak a jármüvezetők figyelmének elterelésére - méretüknél és elhelyezkedésüknél fogva - leginkább

65 Lásd bővebben: TÖRÖK Bernát: A politikai reklámozás magyar szabályozásáról. Érvek a médiakampány nagyobb szabadsága mellett. In: CSERNY Ákos (szerk.): Választási dilemmák. Budapest, Nemzeti Közszolgálati Egyetem, 2015 
alkalmas reklámtáblákat tiltotta meg. ${ }^{66}$ Ezzel szemben egyrészt a szabályozás nem csak kereskedelmi közléseket érintett, másrészt a jogalkotó motivációját illetően jogos kételyek ébredhettek volna. A testület markáns kisebbségében ébredtek is ilyen kételyek, és érvelésükkel azzal együtt azonosulhatunk, hogy a törvénymódosításban a foglalkozás és vállalkozás szabadságának sérelmét látták. Az álláspontjukat megfogalmazó különvélemény szerint a korlátozás alkotmányos célja nem ismerhető fel, mivel az összes körülmény figyelembevételével az állapítható meg, hogy a jogalkotót nem vezethette a közlekedésbiztonság növelésének szándéka. Az érvelés részletesen igyekszik cáfolni a törvényhozó védhető motivációjára vonatkozó feltételezéseket. Egyrészt rámutat arra, hogy a törvény értelmében a vizsgált módosítás előtt is csak olyan reklámtáblát lehetett kihelyezni, jellemzően hatósági engedéllyel, amely a közlekedés biztonságát nem veszélyeztette, és az ennek nem megfelelő táblák eltávolíthatók voltak. Másrészt ha a törvényhozó valóban arra törekedett volna, hogy a biztonságot a gépjármüvezetőket zavaró körülmények kiküszöbölésével, így a gépjármüvezető látóterébe eső vizuális információforrások számának csökkentésével növelje, akkor ezt feltehetően minden azonos típusú vizuális információforrásra megtette volna. Ezzel szemben a lámpaoszlopokra nem, míg a gépjárművezetők látóterébe sokkal inkább beleeső, az úttest közvetlen közelében található, szemmagasságban álló reklámoszlopokra viszont elhelyezhető hirdetés. Ha igaz, hogy a közutak mentén elhelyezett reklámtáblák elterelik a járművezetők figyelmét, akkor ez minden, a közlekedők látóterébe eső reklámtáblára és más látható formációra is igaz, megkülönböztetés nélkül. Ezzel szemben a módosítás egyes táblák kihelyezését megtiltotta, és nem korlátozta a hasonlóan vagy még inkább a jármüvezető látóterébe eső más reklámokat, így nem tilosak az úttesten közlekedő autóbuszokon, trolikon, taxikon elhelyezett reklámok, jóllehet ezek - mozgó mivoltuk, továbbá elhelyezésük miatt - sokkal inkább zavaróak lehetnek, mint az úttest mellett elhelyezett, újonnan tiltott reklámok. További érv a közlekedésbiztonság javítására irányuló motiváció hitelessége ellen, hogy a módosítás egyes kisebb méretü, tehát nehezebben látható, menet közben rövidebb ideig olvasható táblák kihelyezését engedi, míg az addig megengedett nagyobb méretűeket egyes esetekben már nem, holott ezek könnyebben olvashatók, és így kevésbé terelik el a figyelmet. ${ }^{67}$

\footnotetext{
66 3208/2013. (XI. 18.) AB határozat, Indokolás [107]

67 Bragyova András különvéleménye, amelyhez további négy alkotmánybíró (Kiss László, Kovács Péter, Lévay Miklós és Paczolay Péter) csatlakozott. Indokolás [128]-[140]
} 
A fenti érvekkel egyetértve mondhatjuk, hogy jelen esetben a közlekedésbiztonság javítására irányuló törvényhozói szándék vélelme megdöntetett. A magunk szólásszabadság-vizsgálatára vonatkoztatva mindez azt jelenti, hogy a szóban forgó törvénymódosítás a demokratikus nyilvánosságot - a reklámoknál egyébként lényegesen szélesebb körben, így például a választási plakátokra nézve is elfogadható indok nélkül, vagyis valamely más, a véleményszabadság számára irreleváns vagy védhetetlen motiváció mentén szükítette.

Összegző megállapításként leszögezhetjük, hogy a tartalomsemlegesség elvéből kibontott ez a szemléletváltás nemcsak szükségesnek mutatkozik, hanem rendkívüli hozadékkal is kecsegtet az alkotmányossági követelmények érvényesítése terén. A szólás- és sajtószabadság körében manapság ritkábbnak tekinthető eset, amikor tőrőlmetszett tartalomalapú korlátozással állunk szemben, és sokkal gyakoribb, amikor a szabályozó a kommunikációs közeget, infrastruktúrát, szerkezetet próbálja meg befolyásolni. ${ }^{68}$ Kulcsfontosságú, hogy alkotmányjogilag igazolhatatlan motivációval ne tehesse ezt meg - akkor sem, ha a messzebbről tisztességesnek és elfogadhatónak látszó hivatkozásokkal tele a padlás.

\footnotetext{
${ }^{68}$ A szóláskorlátok természetének változására lásd: Jack M. BALKIN: Old School/New School Speech Regulation. 127 Harvard Law Review 22962014
} 


\section{Következtetések}

1. A közlések korlátozásának tartalomsemlegessége az alkotmányossági mérlegelés egyik alapeleme. A tisztázásért kiáltó kihívások ellenére a magyar gyakorlat az európai átlagnál jellegadóbban honosította meg a tartalomalapú vizsgálatot.

2. A tartalomalapú vizsgálat magyar módszere, a „külső korlát” meglétének vizsgálata ugyanakkor jellemzően nem a szólás tartalmától vagy kommunikatív hatásától függetlenül megragadható mércét jelent - már iskolapéldája, az uszítás tesztjének esetében sem.

3. A „külső korlátnak” a személyiségi jogok védelme mellett a közösségek méltósága vagy az alkotmányos alapértékek ellen irányuló közlésekkel szemben is bevett módon használható kategóriája nem lehet alkalmas arra, hogy a tartalomalapú és a tartalomsemleges korlátozások szétválasztásának módszere legyen.

4. A szólás tartalma és módja közti különbségtétel értelmetlen és védhetetlen megkülönböztetés, ha az utóbbi alatt - amint azt a magyar gyakorlat teszi - a közlés stílusát, kifejezésmódját értjük.

5. A tartalmi megközelítés felidézésével középpontba helyezett egyes szempontok nem törtek össze a „külső korlát” ellentmondásainak súlya alatt. E tényezők megragadása mellett ugyanakkor azt is tisztáznunk kell, mely pontokon érdemes meghaladnunk a szigorú tartalmi vizsgálatot.

6. A tartalomsemlegesség érvényes tételei:

6.1. A véleménynyilvánítás jogának a hatálya a nyilvános társadalmi párbeszédben résztvevő közlésekre tartalmuktól függetlenül kiterjed. A hatály alá vonás kérdése nem tehető függővé a konkrét megszólalás tartalmi elemeitől.

6.2. A szólások korlátozásának indokát nem önmagában a tartalomban, hanem a közlés kontextusában kell azonosítani. A véleménynyilvánítás megszorítása nem hivatkozhat önmagában valamely közlés tartalmának értéktelenségére, hamisságára, elfogadhatatlanságára.

6.3. A nézőpontok között szelektáló állami beavatkozás tilalma továbbra is a magyar gyakorlat egyik vezérelve. 
6.4. A hazai doktrína a tartalomsemlegességnek azt a felfogását jeleníti meg, amely elsődlegesen nem önmagában a tartalmat figyelembe vevő szabály jelentette kockázatra, hanem más veszélyre koncentrál: mindenekelőtt a szólásszabadság korlátozásának motivációjára irányítja a figyelmünket.

6.5. Nem önmagában annak van döntő jelentősége, hogy a jogalkotó beavatkozása érinti-e a közlések tartalmát, üzenetét vagy sem, hanem annak, hogy a beavatkozás mögött alkotmányosan védhető vagy védhetetlen indokok, szándékok húzódnak-e meg.

6.6. A nyilvánosság torzítására vagy megszorítására irányuló kormányzati szándék az alkotmányossági vizsgálat során leleplezhető.

6.7. A tartalmi megközelítés jelentette dichotómiából kilépve lehet és kell szigorú szólásszabadság-vizsgálatot folytatnunk: a látszólag tökéletesen tartalomsemleges szabályozást is a legszigorúbb mércével kell megítélnünk, ha az állam mások elhallgattatására irányuló szándéka sejlik föl a körülményekböl.

6.8. A szemléletváltás tétje: napjainkban sokkal gyakoribb, hogy a szabályozó a kommunikációs közeget, infrastruktúrát, szerkezetet próbálja meg befolyásolni kulcsfontosságú, hogy alkotmányjogilag igazolhatatlan motivációval ne tehesse ezt meg. 


\section{A SZÓLÁSSZABADSÁG VÉDELMÉNEK DINAMIKÁJA}

A szólásszabadság magyar doktrínájának alapjait vizsgálva eddig azokat a legfontosabb fogalmi csomópontokat jártuk körül, amelyek a közlések alkotmányos helyének, értékének megtalálásában, valamint a velük szemben felmerülő érdekek jelentőségének kijelölésében kulcsszerepet játszanak. A célunk eddig sem az volt, hogy a véleménynyilvánítás jogához füződő egy-egy konkrét témakör megoldásához nyerjünk kulcsot magunk számára, hanem arra törekedtünk, hogy az egyes témakörökön átívelő, azok számára egyszersmind közös keretet nyújtó legalapvetőbb szempontokat térképezzük fel. Hasonló ambícióval fordulok dolgozatom utolsó, a szólásszabadság korlátozásának tesztjeivel foglalkozó fejezetére. Ezek a tesztek természetesen már az eddigi fejezetekben is fel-felbukkantak, mint ahogy az is nyilvánvalóvá válhatott, hogy számuk lassan, de biztosan közelíti a végtelent. A mérvadó bírósági döntéseket olvasva néha az lehet az érzésünk, hogy ahány véleményszabadságos ügy kerül érdemi eldöntésre, annyi teszt születik meg a

joggyakorlat keretében. Éppen ezért van a szokásosnál is kitüntetettebb jelentősége azoknak az alaptéziseknek, amelyek a sok-sok körülmény és szempont mérlegelésének (azaz teszt alkalmazásának) mélyebb értelmet adnak. A tengernyi mérce azonosításának megkísérlésénél tehát mindenképpen van előrébb való feladat. Arra van szükségünk, hogy ne engedjük a fának, hogy eltakarja az erdőt: az ügyek megoldására vezető eseti formulák helyes alkalmazásához mindenekelőtt figyelemmel kell lennünk a szólások védelmének dinamikájára, azaz a beavatkozás mozgásterét meghatározó alapvető összefüggésekre. Ez a fejezet ugyanis arra a gondolatra épül, hogy a szólásszabadság tesztjeinek dinamikájuk van, amelynek át kell hatnia a konkrét ügyekről való gondolkodásunkat, mert enélkül könnyen, sőt szinte bizonyosan elveszünk a rengetegben.

Ennek a dinamikának a felrajzolása nemcsak hogy épít az eddigi alaptézisekre, hanem részben kifejezetten ezek összegyúrását igényli. Másik részben azonban önálló fogalmi keretre van szükségünk, amelyben szemléletesen elrendezhetők irányadó szempontjaink. Meggyőződésem szerint az e dinamika felrajzolásához szükséges fogalmi keretet adhatja meg számunkra az a diskurzus, amely a szólásszabadság más értékekkel szembeni erejéről folyik. Közhelyszámba megy a szólásszabadság 
elkötelezettjeit abszolutizmussal vádolni, míg az így megvádoltak szemében a véleménynyilvánítás alkotmányos szerepének eljelentéktelenítése tünik föl végzetes hibának a másik oldalon. Ahhoz, hogy hazai doktrínánk kapaszkodóit biztosabb kézzel ragadhassuk meg, rengeteget meríthetünk abból a régóta folyó eszmecseréből, amely a tengerentúlon zajlik a szólásszabadság korlátozásának mozgásteréről.

\section{Abszolutisták és mérlegelők vitája}

A szólásszabadság-tesztek dinamikájával kapcsolatos gondolatok leginkább annak a diskurzusnak a keretében helyezhetők el, amely arra a kérdésre keresi a választ, hogy milyen erővel kell latba vetni a véleménynyilvánítás szempontjait más versengő értékekkel, érdekekkel szemben. Az elméletileg lehetséges válaszok skálájának egyik végpontján a közléseket minden körülmények között alkotmányos védelemben részesítő álláspont áll, a skála másik végén pedig az a nézőpont található, amely szerint a releváns alkotmányos értékek ütközését csakis az adott konkrét ügy eseti tényezőinek ismeretében és mérlegelésével lehet feloldani. A végletesen (és végzetesen) leegyszerüsítő osztályozás szerint míg az Egyesült Államokban az első felfogás uralkodik, addig Európa, benne hazánk, az utóbbi megközelítést követi. Ha ez valóban ennyire világosan szétválasztható lenne, akkor ez esetben az egyébként páratlanul gazdag amerikai irodalom kevésbé lenne alkalmas arra, hogy fogalmi keretet merítsünk belőle a magunk doktrínája számára. A kérdés kutatója számára azonban ezúttal is hamar világossá válik, hogy nincs helye ilyen éles szétválasztásnak: a tengerentúli irodalom nemcsak hogy ismeri „abszolutisták” és „mérlegelők” vitáját, hanem mindenkinél régebb óta szentel neki figyelmet. Az eszmecsere ráadásul természetesen - nem elvont teoretikus jelleggel folyik csupán, hanem az esetjog dilemmáiban és fordulataiban gyökerezve keresi a gyakorlat számára is legkoherensebben alkalmazható válaszokat.

A fogalmi keret lehatárolása szempontjából ugyanakkor lényeges, hogy ennek a dolgozatnak - az amerikai elmélet paradigmáinak felhasználásával, de - a magyar gyakorlat fejleményeinek magyarázata a célja. Arra gondolok, hogy a bírói gyakorlat alakulását követve az amerikai elemzők az utóbbi időben egyre inkább a szigorú vizsgálat (strict scrutiny) és a közepesen szigorú vizsgálat (intermediate scrutiny) 
fogalompár köré rendezve fogalmazzák meg észrevételeiket, elméletüket. Számunkra ugyanakkor ehelyett most paradigmatikusabb és tanulságosabb, ha a diskurzusnak ahhoz a szakaszához nyúlunk vissza, amikor a vitázók a szólásszabadság abszolutista (absolutist) vagy mérlegelő (balancing) védelmének gondolata felől közelítették meg a kérdést. Bár számunkra az ellenkezője sem jelentene gondot, azért érdemes megjegyezni: ezen érvek használatának legitimitását az is erősíti, hogy még ha a tengerentúli doktrína szerkezete némiképp át is alakult, a korábbi érvek és megfontolások továbbra is alapvető alkotóelemei az érveléseknek.

A kérdéskör meghatározó alapvetéseit Laurent B. Frantz és Wallace Mendelson vitája fektette le az irodalomban. Frantz volt az, aki az 1950-es, 60-as évek fordulójának legfelső bírósági döntéseit elemezve elsőként jelentette ki, hogy a korábbi évtizedek kategorikusabb megközelítése után a mérlegelő módszer (balancing) a szólásszabadság központi kérdésévé vált. ${ }^{1}$ A módszer használatának körvonalai még egyáltalán nem voltak pontosítva, és Frantzot éppen az nyugtalanította leginkább, hogy a legkevésbé sem volt látható, vajon alkalmazását a bírák csupán a közlések és korlátozásaik egyes típusainál, vagy esetleg minden ügyre kiterjedően látják célravezetőnek a jövőben. A döntések révén egy dolog tünt biztosnak a számára: a versengő értékek összemérése a doktrína rohamosan terjeszkedő módszere lett, és a maga részéről amellett érvelt, hogy ezt a folyamatot meg kell állítani. Frantz szerint ugyanis ha a szólásszabadság az eseti mérlegelés (ad hoc balancing) zsákmányává válna, akkor megszünne komoly alkotmányos garanciaként funkcionálni. Eseti mérlegelés alatt azt a módszert érti, amely nem a véleménynyilvánítás alkotmány által meghatározott sajátos szerepéből és erejéből indul ki, hanem annak védelmét az adott ügyben felmerülő körülmények összemérésétől függően tartja csak megállapíthatónak. Ez a hozzáállás szerinte az alkotmányt egész egyszerüen üresnek tekinti egészen addig a pillanatig, amikor egy bíró meg nem állapítja a konkrét esetre vonatkozó értelmét. ${ }^{2}$ Frantz határozottan visszautasítja azt a relativizáló álláspontot, mely szerint a szólásszabadság védelmi köre mindenképp mérlegelés eredménye - akár elöre meghatározott kategóriákat állítunk fel, akár eseti mérlegelést végzünk. A perdöntő különbséget abban látja, hogy bár a véleményszabadság hatályát megvonó kategorizálás is szempontok összemérésével jut el a meghatározott eredményre, miután

\footnotetext{
${ }^{1}$ Laurent B. FrantZ: The First Amendment in the Balance. 71 Yale Law Journal 1424 1961-1962. 1432.

${ }^{2}$ FRANTZ (1. 1j.) 1435-1440.
} 
oda eljutott, a jövőre nézve érvényes szabályt eredményez az alkotmányos védelem számára. Ezzel szemben az eseti mérlegelőnek nincsenek világosan elkerített védelmi zónái, hanem bármi a versengő érdekek prédájává válhat. Végső ítélete szerint a mérlegelő módszer dominanciájával a szólásszabadság sérelmét kategorikusan tiltó alkotmányos rendelkezés éppen a szólásszabadság megsértése számára válna menlevéllé. ${ }^{3}$ Frantz alapvető félreértésnek tartja azt a vádat, hogy a mérlegelést mint generális módszert elutasítók a szólásszabadság abszolutistái, akik a józan ésszel szembemenve védelmezik ezt a szabadságjogot. A félreértés alapját az abszolutizmus két értelmének összekeverésében látja: senki nem állítja, hogy a közlések differenciálás nélkül a véleménynyilvánítás alkotmányos hatályába és védelme alá tartoznak - az általa is képviselt álláspont lényege az, hogy az amerikai alkotmány szövege szerint ha egy közlés alkotmányos relevanciával bír, akkor védelme nem rontható le eseti mérlegeléssel. ${ }^{4}$

A mérlegelést egyre inkább előtérbe helyező bírói gyakorlatot Mendelson vette védelmébe Frantz érveivel szemben. Szerinte a kritika alapvető tévedése, hogy a szólásszabadság alkotmányi szabályozását egyértelmünek tartja, holott az szükségszerűen bizonytalan, mivel nincs az angol nyelvben homályosabb kifejezés, mint a „szabadság”, amelynek pontosabb megragadásához a történeti elemzések sem visznek közelebb. ${ }^{5}$ Márpedig az alkotmány a szólás szabadságát védi, nem pedig magát a beszédet. Az Első Alkotmánykiegészítés jelentésének feltárásában segítő biztos kapaszkodók hiányában Mendelson szerint a legjobb, amit a bíróság tehet, hogy a mérlegelő módszerhez folyamodik. A nyílt mérlegelés ugyanis arra szorítja a bírót, hogy teljes felelősséget vállalva döntéséért részletes és racionális módszerrel adjon számot érveiről. A módszer annak megakadályozására is alkalmas, hogy a bíró anélkül érvényesítse egyéni előfeltevéseit, hogy racionális teszttel mérné meg őket. ${ }^{6}$ Mendelson egyáltalán nem tagadja, hogy a mérlegelés alkalmazásával a politikai hatalomnak minden bizonnyal nagyobb mozgástere marad törvényeinek megvédésére a bíróság előtt. Ez azonban számára nem ellenérv, hanem egy mélyebb valóság helyes

\footnotetext{
${ }^{3}$ FRANTZ (1. lj.) 1449.

${ }^{4}$ Frantznak van még egy nagyon szórakoztató megjegyzése azoknak címezve, akik az amerikai irodalomban a mérlegelő módszer mellett azzal (is) érvelnek, hogy az a túlzott bírói aktivizmussal szembeni helyes út. Szerinte ez az érv furcsán hangzik azoknak a szájából, akiknek az elmélete azon alapul, hogy az Első Alkotmánykiegészítésnek a bennefoglalt szavak jelentéséhez képest gyökeresen eltérő értelmet kell tulajdonítani. FRANTZ (1. 1j.) 1445.

${ }^{5}$ Wallace MENDELSON: On the Meaning of the First Amendment: Absolutes in the Balance. 50 California Law Review 821 1962. 821.

${ }^{6}$ Mendelson (5. 1j.) 825.
} 
kifejeződése: alapvető érdekeink és jogaink védelmét végső soron egyébként sem bíráktól, hanem a politikai rendszertől (annak mechanizmusaitól és szerkezetétől) remélhetjük. $^{7}$

Válaszában Frantz a korábbi érveit fejtette tovább. Leszögezte: nem állítja, hogy a bíróságoknak sosem kellene mérlegeléssel dönteniük, akár a szólásszabadságot érintő egyes ügyekben is. Érvelésének lényege, hogy a véleménynyilvánítás körében nem lehet a mérlegelgetést általános alapelvvé tenni, azt állítva, hogy az alkotmányos védelem önmagában nem mond sokat, amíg a bíró az adott ügy eseti körülményei között meg nem állapítja a szólásszabadság elsőbbségét. A véleményszabadságot érintően a bírák nem cserélhetik le eseti mérlegelésre azt a törekvésüket, hogy az alkotmányban gyökerező általános érvényü tételeket alkalmazzanak a konkrét esetekre. ${ }^{8}$ Mendelson cikkét leleplezőnek tartja ebből a szempontból, mert abból tulajdonképpen az a nézőpont világlik ki, hogy a bíráknak az alkotmány mindig homályos szövegét félretéve inkább esetröl esetre haladva kell feloldaniuk az érdekütközéseket. Frantz szerint igaz ugyan, hogy egy alkotmányi szabály rendszerint nem tudja önmagában konkretizálni a jelentését, viszont ha az alkotmány egészének értelméből és összefüggéseiből közelítünk felé, akkor már világosan kidolgozhatók a szólásszabadság lényegi tételei, amelyeket a bíráknak minden egyes ügyben érvényesíteniük kell mint a politikai hatalom cselekvésének korlátját. Ezzel szemben a mérlegelés tesztje szerint az alkotmány parancsa mindössze annyit mond: ne sértsd a szólásszabadságot addig, amíg azt nem gondolod, hogy meg kell sértened. ${ }^{9}$ Frantz úgy látja, hogy általánosan kötelező tételek nélkül a mérlegelés metaforája teljesen kiüresedik, hiszen semmilyen támpont nem marad a versengő értékek, érdekek súlyozására. Válaszában végül ismét fantomokkal vívott harchoz hasonlítja az abszolutistákkal szembeni küzdelmet: tekintettel arra, hogy a szólásszabadság korlátlanságát - más-más logika mentén, de - valójában senki nem képviseli, a „szólásszabadság sem korlátlan” jelszót zászlajukra tüzők igazából csupán a kényelmesebb utat választják, hogy e szabadságjog valódi tartalmának feltárása helyett kedvük szerint tehessék félre szempontjait. ${ }^{10}$

\footnotetext{
7 Ahogy Mendelson zárja érvelését: „Az ember végső soron politikai, nem pedig jogi lény.” MENDELSON (5. lj.) 827.

${ }^{8}$ Laurent B. FranTZ: Is The First Amendment Law? - A Reply to Professor Mendelson. 51 California Law Review 7291963.732.

${ }^{9}$ FRANTZ (8. 1j.) 744.

${ }^{10}$ FRANTZ (8. lj.) 751 .
} 
A nagy figyelmet érdemlö vitát Mendelson viszonválasza zárta. Frantz félelmeit valószínüleg cseppet sem eloszlatva fejtette ki, hogy a mérlegelés szükségszerüen - de legalábbis üdvözlendő fejleményként - válhat általános módszerré a szólásszabadság területén is, mivel az felel meg leginkább a bírói döntés lényegének: az absztrakt jog és a konkrét valóság összevetésének ${ }^{11}$. A kérdés valójában csupán az, hogy a bíró a súlyozást intuíciói alapján és rejtve, avagy racionális keretek között és nyíltan végzi-e el. A mérlegelés tehát maga a realizmus, szemben azzal a modern aktivista megközelítéssel, amely előbb kidolgoz egy jól hangzó tételt (a szólásszabadság terén például a clear and present danger szabályt), majd minden nehézség megoldására alkalmas talizmánként tekint rá, addig tágítva ezzel hatályát, hogy végső soron teljesen értelmezhetetlen kategóriává válik. ${ }^{12}$ Mendelson a maga részéről azzal zárja a vitát, amivel kezdte: önámítás, hogy minden szólásszabadság-ügy megoldása kiolvasható magából az alkotmányból, ezért igenis szükség van a bírói mérlegelés szabadon engedésére.

A lényeget tekintve Mendelsonnal ért egyet Steven Shiffrin, aki a mérlegelés megkerülhetetlenségét szintén abból vezeti le, hogy a szólásszabadság doktrínájának nincs egyetlen igazoló elve, amire bármilyen abszolutisztikus álláspont visszavezethető lenne. ${ }^{13}$ A véleménynyilvánítás jogának nem bontható ki egy olyan központi magja, amelynek védelmében megingathatatlan kategóriákat állíthatnánk föl, ezért nem marad más, mint rendkívül összetett szempontrendszer értékelésével meghozni döntéseinket. Shiffrin annak ellenére jut ennek belátására, hogy az abszolutista álláspontot nem tartja terméketlennek. ${ }^{14}$

Terméketlen vitának tartotta a fentieket Harry Kalven, amikor az abszolutista álláspont egyik ikonikus alakjának, Black legfelső bírósági bírónak a munkásságát összegezte és méltatta. ${ }^{15}$ Szerinte a vita nemkívánatos, félrevezető és szükségtelen, mivel filozofikus magasságba emel egy olyan kérdéskört, amelynek egyébként a technikai részletekre kellene összpontosítania. Ha a gyakorlati tényezőkre irányítjuk

\footnotetext{
${ }^{11}$ Wallace Mendelson: The First Amendment and the Judicial Process: A Reply to Mr. Frantz. 17 Vanderbilt Law Review 479 1963-1964. 481.

${ }^{12}$ Mendelson (11. lj.) 483.

${ }^{13}$ Steven SHIFFRIN: Defamatory Non-media Speech and First Amendment Methodology. 25 UCLA Law Review 915 1977-1978. 955.

14 SHIFFrIN (13. lj.) 958-961. Különösen értékesnek tartja Melville B. Nimmel később tárgyalt, alapjában véve kategorizáló teóriáját.

15 Harry KALVEN, Jr.: Upon Rereading Mr. Justice Black on The First Amendment. 14 UCLA Law Review 428 1966-1967. 441.
} 
figyelmünket, akkor azt találjuk, hogy nemegyszer az abszolutizmus bajnokai, köztük Black bíró is a versengő szempontok mérlegelése után hozták meg eseti döntésüket, míg bizonyos kérdések felmerülésekor a mérlegelő módszer hívei is kategorikus egyértelmüséggel léptek föl. Kalven úgy látja, hogy felesleges ebben a körben a szólásszabadság általános módszerének filozófiájáról vitatkozni, mivel a mérlegelés csupán azoknak az ügyeknek a technikája, amikor az egyébként nem a közléseket célzó szabályozás mellékesen a szólásszabadságra is korlátozó hatással van. Gyümölcsözőbb lenne ezért a technikai részletekre, nem pedig absztrakt elméleti kategóriákra fókuszálni. ${ }^{16}$

Kalvennal szemben azonban a vita többi résztvevője amellett tört lándzsát, hogy a szólásszabadság korlátozása módszerének mélyebb természetéről folytatott diskurzus fontos szempontokkal gazdagítja szemléletünket - jól érzékelteti például, hogy a szélsőséges álláspontoktól érdemes távol tartanunk magunkat. Melville B. Nimmer szerint a New York Times v. Sullivan ügy mutatja meg számunkra a követendő harmadik - mind az abszolutizmus, mind az eseti mérlegelés komoly veszélyeit elkerülő - utat. ${ }^{17}$ Nimmer az általa kategorizáló mérlegelésnek (definitional balancing) nevezett módszer lényegét abban látja, hogy a legendás döntés meghozatalakor a bíróság a súlyozást elsődlegesen nem a konkrét per szintjén ( $a d$ hoc) végezte el, hanem a szólásszabadság védelmi körének meghatározására fókuszálva. A mérlegelés célja ilyenkor az alkotmányossági szempontból releváns kategóriák felrajzolása és azonosítása az egyedi ügyben, nem pedig az egyedi ügy valamennyi körülményének összetett ütköztetése. Nimmer meglátása szerint a New York Times ügyben a bíróság addig végzett mérlegelést, amíg megtalálta és szabályba foglalta a rágalmazó állítások védettségének határát, de azon túl már nem kezdte el méricskélni, hogy az előtte fekvő ügy feleinek esetleg milyen egyedi érdekei tarthatnak igényt az értékelésre. A kategorizáló mérlegelés tehát nem önmagában a szóban forgó vitás közléshez kötődő érdekeket tartja szem elött, hanem a közlés által képviselt szólások általánosabb szempontjait. Nimmer számára a mérlegelés szintjének azért van döntő jelentősége, mert amennyiben a szólásszabadság eseteit csupán önmagukban, elszigetelt ügyekként

\footnotetext{
${ }^{16}$ KALVEN (15. lj.) 442-443.

${ }^{17}$ Melville B. NIMMER: The Right to Speak from Times to Time: First Amendment Theory Applied to Libel and Misapplied to Privacy. 56 California Law Review 935 1968. 942.
} 
vizsgálnánk, a szólás érdekét rutinszerűen ásná alá a vele konkuráló és általában átélhetőbb érdek, sérelem. ${ }^{18}$

John Hart Ely még következetesebben igyekezett rámutatni arra, hogy a legfontosabb valójában a kategorizálás és a mérlegelés szempontjainak helyes vegyítése. A szólásszabadságról folytatott eszmecsere egyik nagy félreértésének tartja, hogy a két nézőpont kölcsönösen kizárná egymást annak a sokféle különböző problémának a megoldásakor, amellyel a szólásszabadság szembesít minket. ${ }^{19} \mathrm{Az}$ abszolutistáknak bizonyára igazuk van abban, hogy módszerük alkalmasabb a szólásszabadság védelmezésére válságos időkben, de ugyanennyire biztos az is, hogy generális alkalmazása ostoba eredményekre vezet. A véleményszabadság érdekét tehát valójában az szolgálja, ha felismerjük, hogy kategorizálás és mérlegelés nem egymást kizáró elméleti konstrukciók, hanem a maguk terrénumán belül a doktrína nélkülözhetetlen módszerei. Míg bizonyos eszmék veszélyesnek bélyegzése esetén a mérlegelés teljesen kiszolgáltatja a szólásszabadság alkotmányos értékét a mérlegelő szubjektív előfeltevéseinek és ideológiájának - vagy ha annak nem, az aktuális korszellem paranoiáinak mindenképp -, addig jól alkalmazható módszer lehet akkor, amikor a korlátozás más, semleges szemponton alapul. ${ }^{20}$

A fenti megfontolásokat végül Laurence $H$. Tribe igyekezett rendszerbe foglalni. Kalvennal szemben ő is úgy látta, hogy a vita összességében fontos meglátásokat hozott felszínre, amelyek szépen összefonhatók a szólásszabadság-diskurzus egyéb szálaival. ${ }^{21}$ Elyvel egyetértve az abszolutista/mérlegelő szemlélet dichotómiája ugyanis szerinte is jól illeszkedik az alkotmányos vizsgálatnak ahhoz a két útjához, amelyet a doktrína többi szempontja is támogat. A közlések kommunikatív hatását célzó hatósági fellépések esetében vélelem szól azok alkotmányellenessége mellett, ami másképpen fogalmazva azt jelenti, hogy bármely elméleti érvet vagy veszélyes következményt hoznánk is fel bizonyos nézetek terjesztése ellen, a szólás szabad közlése és annak veszélye közti döntést maga az alkotmány már meghozta helyettünk. Ezzel szemben amikor valamely beavatkozás a közlések nem-kommunikatív hatását célozza, akkor sor kerülhet a versengő érdekek (például az utcák tisztaságának) figyelembevételére,

\footnotetext{
${ }^{18}$ NIMMER (17. lj.) 943-945.

${ }^{19}$ John Hart ElY: Flag Desecration: a Case Study in the Roles of Categorization and Balancing in First Amendment Analysis. 88 Harvard Law Review 1482 1974-1975. 1500.

${ }^{20}$ ELY (19. lj.) 1501.

${ }^{21}$ Laurence H. TRIBE: American Constitutional Law (Second Edition). Mineola, NY, The Foundation Press, 1988. 792.
} 
ami azután természetes módon vezet az ellentétes szempontok súlyozására. Ilyenkor a döntést, a helyes egyensúly megtalálását nem határozza meg helyettünk az alkotmány, ehelyett arra szólít fel, hogy a mérlegelést a szólásszabadság központi szerepének szellemében végezzük el. ${ }^{22} \mathrm{Az}$ alkotmányos vizsgálat egyik útján tehát az abszolutisták, a másikon a mérlegelők megközelítésének kell előtérbe kerülnie. A gyakorlati alkalmazáson túl Tribe szerint mindkét nézőpontnak megvan a maga mélyebb igazsága is. A mérlegelőknek alighanem igazuk van abban, hogy lehetetlen megszabadulni a versengő értékek súlyozásának feladatától: a kategorikus szemlélet hasonló logikában állítja fel kategóriáit, így a kérdés leginkább az, hogy az egyensúlyt valamennyi esetre kiterjedően (kategorikusan) állapítjuk meg, vagy pedig esetről esetre újra elvégezzük a mérlegelést. Az abszolutisták igazságát Tribe abban látja, hogy módszerük hosszútávon, de különösen válságos időkben, alkalmasabb a szólásszabadság védelmezésére. ${ }^{23}$

A számunkra a magyar doktrína keretezéséhez szükséges elméleti szempontok kifejtését ezzel le is zárhatnánk. Két szerzőt mégis érdemes még megemlítenünk annak demonstrálása érdekében, hogy az ,abszolutizmus vagy mérlegelés” vita érvei a tengerentúlon sem vesztettek jelentőségükből, annak ellenére, hogy a bírósági indokolások nyelvezete átalakult, és mára teljes mértékben a szigorú vizsgálat (strict scrutiny) és a közepesen szigorú vizsgálat (intermediate scrutiny) fogalompárja felé fordult. Az új nyelvezet azonban nem feltétlenül jelenti a korábbi megfontolások meghaladását. T. Alexander Aleinikoff mutat rá arra, hogy míg a szigorú vizsgálat mércéje bizonyos érdekek valódi kizárásával kellően határozott módszer, addig a többi teszt a meghatározatlan érdekek összemérésének alkotmányos vizsgálatra valójában alkalmatlan eszköze. ${ }^{24}$ Ronald Dworkinnal egyetértve fejti ki, hogy alkotmányos jogokat, így a szólásszabadságot nem lehet érdekek végtelen mérlegelésének kiszolgáltatni, mert azzal lényegük vész el. Látni kell, hogy Aleinikoff már régen nem egy kizárólagos abszolutizmus mellett érvel, hanem az alakuló bírói gyakorlat tükrében az eseti mérlegelés mindenhatóságába vetett hitet igyekszik megingatni.

Ugyanezzel a céllal melegíti föl a korábbi diskurzus érveit Ashutosh Bhagwhat is. A közepesen szigorú vizsgálat módszerében ő is a kellően szilárd tételek nélküli

\footnotetext{
22 TRIBE (21. lj.) 791.

23 TRIBE (21. lj.) 793.

24 T. Alexander ALEINIKOFF: Constitutional Law in the Age of Balancing. 96 Yale Law Journal 943 1986-1987. 946.
} 
mérlegelést azonosítja, és Scalia legfelső bírósági bíróval egyetértve állapítja meg, hogy idővel ez vált a doktrína központi eszközévé és minden alkotmányossági vizsgálat kiindulópontjává. ${ }^{25}$ A módszer veszélyét abban látja, hogy valójában mindenféle kontúrt nélkülözve nem ad eligazítást arra nézve, hogy hogyan kell súlyozni. Mivel a túlburjánzó módszer nem emeli ki kellőképpen a közlésekhez füződő, különösen védendő értékeket sem, fennáll a veszélye, hogy idővel szépen lassan „felzabálja” öket. ${ }^{26}$

\section{A dilemma létjogosultsága a magyar dogmatikában}

Mielőtt a releváns jogesetek áttekintésével belevágnánk annak elemzésébe, hogy a magyar doktrína hogyan helyezkedik el abszolutizmus és eseti mérlegelés skáláján, ki kell térnünk annak az előzetes kérdésnek a megválaszolására, hogy egyáltalán értelmes-e a kérdésfeltevés a mi számunkra. Nem arról van-e szó, hogy az egyik döntő különbség az amerikai és az európai nézőpont között éppen az, hogy míg az előzőben helye lehet az abszolutista megközelítésnek, addig az utóbbi eleve az arányossági teszt különféle változataira alapozza az alkotmányossági vizsgálatot, márpedig az az alapjogi összeütközések mérlegelő feloldásának a módszere. Ezzel összhangban jellemzőnek mondható, hogy a véleménynyilvánítással kapcsolatos ügyekben a vele konkuráló értékek javára érvelők annak hangzatos kinyilvánításával kezdik érveiket, hogy a szólásszabadság nem abszolút, nem korlátozhatatlan. ${ }^{27}$ Mindezen megfontolások mélyén valójában olyan álláspont húzódik meg, amely szerint eleve, fogalmilag kizárt a hazai dogmatikában abszolút védelemről beszélni. Erre az álláspontra e dolgozat keretei között csupán nagyon röviden, annak erejéig reagálunk, hogy felhívjuk az alapjogok korlátozhatóságának kérdéséről folytatott hazai eszmecserében kifejtett azokat a gondolatokat, amelyek számunkra most a továbblépéshez szükségesek. A problémakört a súlya és összetettsége nyilvánvalóan önálló értekezés tárgyává teszi, és ennek megfelelően a hazai szakirodalomban is gazdag és termékeny vitára találhatunk. E helyütt nem az a célom, hogy ehhez a

\footnotetext{
25 Ashutosh Bhagwhat: The Test That Ate Everything: Intermediate Scrutiny in First Amendment Jurisprudence. 2007 University of Illinois Law Review 783 2007. 785.

${ }^{26}$ BHAGWHAT (25. lj.) 820.

27 Csak a példa kedvéért lásd a 95/2008. (VII. 3.) és a 7/2014. (III. 7.) $\mathrm{AB}$ határozathoz csatolt különvéleményeket.
} 
vitához új gondolatokkal csatlakozzak, sokkal inkább az, hogy a szólásszabadság doktrína megértéséhez szükséges szempontokat felvillantsam belöle. Ez persze, mint látni fogjuk, egyrészt érdemi állásfoglalást jelent a versengő megfontolások között, másrészt a véleményszabadság elhelyezése szemléletes példával gazdagítja az eredeti diskurzust.

Annak odáig mindenki számára világosnak kell lennie, hogy az abszolút alapjogi védettség fogalma bizonyosan nem hiányzik teljes mértékben a magyar dogmatikából: az élethez és az emberi méltósághoz való jog korlátozhatatlansága jogállami alkotmányos rendünk egyik szilárd alapjává vált. A halálbüntetés eltörléséröl döntő 23/1990. (X. 31.) AB határozat indokolása szerint „,[a]z emberi élet és az emberi méltóság elválaszthatatlan egységet alkot és minden mást megelőző legnagyobb érték. $\mathrm{Az}$ emberi élethez és méltósághoz való jog ugyancsak egységet alkotó olyan oszthatatlan és korlátozhatatlan alapjog, amely számos egyéb alapjognak forrása és feltétele. (...) Az emberi élethez és méltósághoz mint abszolút értékhez való jog korlátot jelent az állam büntetőhatalmával szemben." ${ }^{28} \mathrm{Az}$ idézett mondatok széles körben ismertek, elfogadottak és egyszersmind az abszolút védelem logikájának kategorikus végét jelentik sokak számára. Ezen álláspont szerint - még ha bizonyos alkotmányi normák, például a nullum crimen sine lege vagy az ártatlanság vélelme kivételt nem engedő védelmet is nyújtanak alanyuk számára - az élethez és méltósághoz való jogon túl egyáltalán nincs értelme és alapja felhívni a szabadságjogok abszolút védelmének szempontját. Nincs ez másként a szólásszabadsággal sem, amivel kapcsolatban maga a 30/1992. (V. 26.) AB határozat szögezte le, hogy az az élethez és méltósághoz való joggal ellentétben nem korlátozhatatlan. ${ }^{29}$ Hogy az abszolút védettség logikájának teljes kizárása mellett lándzsát törő, paradox módon éppen hogy „abszolutista” állásponttal szemben valóban megadásra kényszerül-e az európai alapjogi dogmatika, arra világíthat rá az általános alapjogi teszt természetéről, illetve hozzá kapcsolódóan a jogok lényeges tartalmáról folytatott diskurzus, amire az elmondottak fényében csak röviden utalunk.

A rendszerváltó alkotmány több mint húsz éven át hatályos szövege akként fogalmazta meg az alapjogok korlátozásának szabályát, hogy „[a] Magyar Köztársaságban az alapvető jogokra és kötelességekre vonatkozó szabályokat törvény

\footnotetext{
${ }^{28}$ 23/1990. (X. 31. ) AB határozat, Indokolás V.2., ABH 1990, 88, 93.

29 30/1992. (V. 26.) AB határozat, Indokolás V.1., ABH 1992, 167, 178.
} 
állapítja meg, alapvető jog lényeges tartalmát azonban nem korlátozhatja." ${ }^{30} \mathrm{Az}$ Alaptörvény I. cikk (3) bekezdése ehhez képest az Alkotmánybíróság által kidolgozott dogmatikát beépítve bővebben fogalmaz: „Az alapvető jogokra és kötelezettségekre vonatkozó szabályokat törvény állapítja meg. Alapvető jog más alapvető jog érvényesülése vagy valamely alkotmányos érték védelme érdekében, a feltétlenül szükséges mértékben, az elérni kívánt céllal arányosan, az alapvető jog lényeges tartalmának tiszteletben tartásával korlátozható.” Mindkét alkotmányszöveg alapján fontos dogmatikai kérdéssé vált az Alkotmánybíróság által alkalmazott szükségességarányosság tesztnek és a „lényeges tartalom” fogalmának a viszonya.

A kérdés számunkra most releváns alapvonalait Györfi Tamás fogalmazta meg. A lényeges tartalom helyét keresve a korábbi alkotmány hatálya alatti alapjogkorlátozás módszertanában ő arra mutatott rá, hogy míg az arányossági teszt a korlátozás jellemvonásaira vagy két szembenálló szempont viszonyára utal, addig a lényeges tartalom „,az alapjog jellemző vonása”. ${ }^{31}$ Fontos elvi megállapítása, hogy a lényeges tartalom arányos korlátozása éppúgy elképzelhető, mint a nem-lényeges rész esetében az aránytalan, mivel ennek ellenkezője semmiképp sem következik abból, hogy a lényeges tartalom érintettsége esetén súlyosabb indokra van szükség. ${ }^{32}$ A lényeges tartalom fogalma Györfi szerint arra utal, hogy „egy jognak van egy központi alkalmazási területe, ami ennek a jognak a lényegét adja, amire ez a jog való, ami e jog legfontosabb funkciója". ${ }^{33}$ E gondolatok alapján akkor is nagyon fontos következtetések levonására juthatunk el, ha egyébként osztjuk Györfi végkövetkeztetését, mely szerint „a lényeges tartalom tesztje - adottnak véve az alkotmány lényeges vonásait - önmagában müködésképtelen.” ${ }^{34}$

E következtetések levonására annál inkább érdemes sort kerítenünk, mert Győrfi konklúzióját nem vitatva érthetünk egyet Pozsár-Szentmiklósy Zoltánnal abban, hogy „az alapjogok lényeges tartalmának védettsége olyan fogalom, amely önálló elemként is bekapcsolható az alapjogkorlátozás tartalmi vizsgálatára irányuló érvrendszerbe". ${ }^{35}$

\footnotetext{
30 1949. évi XX. törvény 8 . § (2) bek.

${ }^{31}$ GYÖRFI Tamás: Az alkotmánybiráskodás politikai karaktere. Értekezés a magyar Alkotmánybíróság elsö tíz évéröl. INDOK, Budapest, 2001. 83. (kiemelés az eredetiben)

${ }^{32}$ GYÖRFI (31. 1j.) 83-84.

${ }^{33}$ GYÖRFI (31. 1j.) 85.

${ }^{34}$ GYÖRFI (31. lj.) 90. (kiemelés az eredetiben). Csak a rend kedvéért: Győrfi gondolatai azzal együtt alapvető jelentőségü fogódzók lehetnek számunkra, hogy a korábbi Alkotmány szabályaiból kiindulva fogalmazta meg őket.

35 POZSÁR-SZENTMIKLÓSY Zoltán: Alapjogok mérlegen. Az általános alapjogi teszt dogmatikája. HVGORAC, Budapest, 2016. 207.
} 
Az irodalmi és a jogalkalmazói áttekintést záró konklúziója szerint a magyar gyakorlat főszabályként az alapjogi teszt alkalmazásával határozza meg a lényeges tartalom sérelmét, ami azt jelenti, hogy a fogalom relatív megközelítése az uralkodó szemlélet. A dominancia mégsem jelent kizárólagosságot: kivételesen, kiemelt védelemben részesített alapjogokkal kapcsolatban, tartalmi jegyek megadásával sor kerülhet e logika áttörésére. ${ }^{36}$

Hasonló következtetésre jutott korábban Sonnevend Pál is, aki két fontos megjegyzést füzött ahhoz az általa is megállapított kétségtelen tényhez, hogy az Alkotmánybíróság a korábbi alkotmány hatálya alatt a lényeges tartalom garanciájának elsődlegesen relatív, a szükségesség-arányosság teszt segítségével azonosítható értelmet tulajdonított. Szerinte ezt egyrészt az árnyalja, hogy mindezek ellenére a hazai gyakorlat ismeri egyes jogok, kiváltképp az élethez való jog abszolút védettségét, másrészt az, hogy az alkotmánybíráknak nem állt rendelkezésükre más, mint a korábbi alkotmány lényeges tartalomra utaló fordulata, így abból kellett levezetniük az alapjog-korlátozás mércéjét. ${ }^{37}$ Mindezek figyelembevételével Sonnevend szerint „nem ésszerütlen feltételezni, hogy a lényeges tartalom garanciája - azon túl, hogy az egyedi esetekben az arányosság elvének megfelelően engedi korlátozni a legtöbb alapvető jogot - általános jelentőséggel is bír. (...) Más szóval a magyar alkotmány lényeges tartalom garanciája nem pusztán szubjektív és egyben relatív módon értelmezhető és alkalmazható, hanem van egy objektív és egyben abszolút dimenziója is." "38

Az alapjogok abszolút védettségének gondolata tehát egyáltalán nem tabu a magyar szakirodalomban - senki nem állítja, hogy meghatározó, többségi irányvonala lenne a hazai dogmatikának, de jelenléte, akár az élethez való jogon túlmutató érvénnyel is, nem vitatható. Olyannyira nem, hogy az Alaptörvény hatálybalépésével ez a logika erősödni látszik: mint láttuk, az új alkotmányszöveg a szükségesség-arányosság teszt inkorporálása mellett külön utal a lényeges tartalom fogalmára, így annak szempontjai erősebb legitimást kaptak.

A relatív értelmezés meghatározó erejére tekintettel mindazonáltal nagyobb gyakorlati jelentőséggel bír Pozsár-Szentmiklósynak az a megállapítása, hogy bár a lényeges tartalom fogalma kapcsán nem beszélhetünk önálló mércéröl, annak

\footnotetext{
${ }^{36}$ POZSÁR-SZENTMIKLÓSY (35. 1j.) 221.

${ }^{37}$ SONNEVEND Pál: Alapvetö jogaink a csatlakozás után. Fundamentum 2003/2. szám, 33-34.

${ }^{38}$ SONNEVEND (37. lj.) 34.
} 
vizsgálata önálló funkcióval rendelkezhet, és erösítheti az alapjogvédő érvelést. Funkciója elsősorban az adott jog sajátosságaihoz füződő tartalmi elemek rögzítése, vagyis a korábbi megközelítések közül alkalmazhatónak tünik a lényeges tartalmat adott kontextusban rögzítő megoldás. ${ }^{39}$ Végső következtetése szerint „[a] bírói fórumok tehát abban az esetben alapíthatják döntésüket meggyőző és igazolható érvekre, ha föszabály szerint az alapjogi tesztet alkalmazzák, az alapjog lényeges tartalmához tartozó szubsztantív elemek vizsgálatát pedig a kiemelt védelemben részesített jogokkal kapcsolatos alapjogi konfliktusokra, valamint a többi alapjog esetében - az alapjogi teszt részeként - a kizárólag egyértelmủ érvekkel alátámasztható helyzetekre korlátozzák." ${ }^{\circ 0}$

A fentiekből számunkra most az a legfontosabb következtetés, hogy az alapjogok korlátozásának magyar dogmatikájától nem idegen bizonyos körben abszolutisztikus gondolatokat képviselni. Félreértés ne essék, nem amellett érvelek, hogy akár a szólásszabadság, akár más szabadságjog az emberi élethez és méltósághoz való jog sorsát osztaná a teljes korlátozhatatlanságban. Nem mellesleg egy ilyen álláspont nyilvánvaló ellentmondásban állna a dolgozat eddigi részeivel. Állításom lényege a következő: attól még, hogy egy alapjog széles hatálya alatt akár szerteágazó korlátozásokra is sor kerülhet, ugyanaz az alapjog rendelkezhet olyan réteggel, ahol már az abszolutista álláspont megfontolásainak kell előtérbe kerülniük. Az elmondottak fényében ráadásul ez nemcsak abszolút védelemre igényt tartó egyéni pozícióként képzelhető el, hanem a lényeges tartalom kategóriájának használatával adott körben tartalmi elemekkel is megragadható. A dolgozat eddigi elemzéseire támaszkodva kellő magabiztossággal jelenthetjük ki, hogy a szólásszabadság egészen biztosan olyan alapjog, amelynek doktrínáján belül az abszolutista logika érvényesülésének is meglehet a maga helye. A véleménynyilvánítás dogmatikája ugyanis rendelkezik azzal a két fogalmi elemmel, ami a fentiek alapján a legerősebb érveket szolgáltatja a kategorikusabb megközelítés felbukkanásához

Egyrészt nem lehet kérdéses, hogy kiemelt alapjogról van szó. Ezt éppen az a már sokat idézett mondat tette először egyértelművé, ami egyébként a korlátozhatatlanságát is elutasította. A 30/1992. (V. 26.) AB határozat nagyhatású kijelentése szerint „,[a] szabad véleménynyilvánítás jogának kitüntetett szerepe ugyan nem vezet arra, hogy ez

\footnotetext{
${ }^{39}$ POZSÁR-SZENTMIKLÓSY (35. lj.) 221-222.

${ }^{40}$ POZSÁR-SZENTMIKLÓSY (35. lj.) 225. (kiemelés az eredetiben)
} 
a jog - az élethez, vagy az emberi méltósághoz való joghoz hasonlóan korlátozhatatlan lenne, de mindenképpen azzal jár, hogy a szabad véleménynyilvánításhoz való jognak valójában igen kevés joggal szemben kell csak engednie, azaz a véleményszabadságot korlátozó törvényeket megszorítóan kell értelmezni." ${ }^{41}$ Ennek az alkotmányértelmezésnek az ereje mindvégig kitartott az évtizedek során, és nem érhetett senkit meglepetésként, amikor az Alkotmánybíróság az új alkotmány értelmezésekor is ugyanerre az alapra helyezkedett. A 7/2014. (III. 7.) $A B$ határozat tételszerü megállapítása értelmében ,[a] szabad véleménynyilvánításhoz való jog kitüntetett helyet foglal el az Alaptörvény alapjogi rendjében", ami azt eredményezi, hogy „csak kivételes jelleggel kell engednie a korlátozására felhozott más jogokkal és alkotmányos értékekkel szemben." ${ }^{22}$ Míg tehát az Egyesült Államokban sokan az Első Alkotmánykiegészítés kategorikus fogalmazásából vezetik le a szólásszabadság különös erejét, addig a magyar doktrínában az Alkotmánybíróság gyakorlata tette azt vitathatatlanná. A különbség azonban látszólagos. Nem arról van ugyanis szó, hogy az Alkotmánybíróság a szövegben láthatatlan elvek kidolgozásával „puccsolta volna meg” az alkotmány rendelkezéseit, hanem arról, hogy egy valódi demokratikus alkotmány nem is értelmezhető másként: maga a demokratikus berendezkedést konstituáló alaptörvény az, amely az önkormányzáshoz teljes mértékben nélkülözhetetlen véleménynyilvánítást kitüntetett szereppel ruházza fel. ${ }^{43}$

Másrészt e dolgozatban részletesen feltártuk, hogy a szólásszabadság magyar doktrínájában megragadhatók azok az elemek, amelyek a lényeges tartalom fogalmához közelebb visznek. ${ }^{44}$ Ennek körében nem egyszer s mindenkorra rögzített konkrét tartalmi jegyeket azonosítottunk, hanem azokat az alkotmányos tételeket vettük számba, amelyek egy ilyen központi mag körvonalait jelenthetik. Kiindulópontunk az volt, hogy a hazai gyakorlatban feltárható a véleményszabadság átfogó igazoló elve, amelyre egy ilyen konstrukció felépíthető. Esetünkben tehát a lényeget érintően nincs igaza Steven Schiffrinnek: még ha nem is mondhatjuk, hogy a szólásszabadságnak egyetlen kizárólagos igazoló elve van, a demokratikus részvétel modellje kellőképpen védhető és tisztázható keretet nyújt ahhoz (is), ha bizonyos körben abszolutisztikusabb megközelítés számára keresnénk fogódzókat.

\footnotetext{
${ }^{41}$ 30/1992. (V. 26.) AB határozat, Indokolás V.1., ABH 1992, 167, 178

42 7/2014. (III. 7.) AB határozat, Indokolás [39], [42]

${ }^{43}$ A dolgozat első fejezete valójában éppen ezt a kérdéskört járta körül.

${ }^{44}$ Lásd az első két fejezetet.
} 
Bár iménti következtetéseink túlfutnak az általa megfogalmazottakon, a lényeges tartalom és a véleményszabadság nem szokványos kapcsolata mellett érvelve Sólyom László gondolataiból is meríthetünk. Az Alkotmánybíróság első elnöke egyfelől maga sem hagyott kétséget afelől, hogy mivel az előző alkotmány csakis egy korlátot, a lényeges tartalom sérthetetlenségét írta elö, „elvileg következetesen és a gyakorlati igényekkel összhangban ezt a szükségesség és arányosság ismérvével kell meghatározni". ${ }^{45}$ A lényeges tartalom abszolút kategóriája helyett ezért a hazai dogmatika kezdettől fogva a fogalom relatív megragadásának útján indult el. Másfelől ugyanakkor rámutat arra is, hogy ezzel együtt egyes alapjogokkal kapcsolatban „további ismérveket vezetett be az Alkotmánybíróság, amelyek egy része módszertanilag túlmutat eddigi alkalmazási területén”. Sólyom mindenekelőtt éppen a véleménynyilvánítás jogát nevesíti, amely köré a gyakorlat a szokásos alapjogi mérlegeléshez képest „rendkívül erős védelmet épített”" ${ }^{36}$

\section{A szabadabb mérlegeléstől az alaptörvény-ellenesség vélelméig}

A szólásszabadság-tesztek dinamikája után kutatva - vagyis az alapjogkorlátozás általános módszertanának vonatkozó specifikumait keresve - annak a tételnek a jelentését kell alaposabban körbejárnunk, mely szerint a véleménynyilvánítás kitüntetett szerepéből adódóan a közlés szabadságának „csak kivételes jelleggel kell engednie a vele szemben felhozott más jogokkal és alkotmányos értékekkel szemben". 47 Kizárólag a rend kedvéért rögzítjük a magától értetődőt, hogy ezt megelőző lépésként az Alkotmánybíróság természetesen a véleménynyilvánítás jogának korlátozására is az általános alapjogi teszt módszertanát, a magyar judikatúrában és irodalomban szükségesség-arányosság tesztnek nevezett mércét tartja irányadónak. Az általános módszertanon belül azonban a fenti kulcsmondat éppen e jog korlátozásának különlegességét igyekszik megragadni. Bár a tétel differenciálás nélkül, a véleményszabadság teljes hatályára szóló érvénnyel fogalmazódott meg, a korlátozás dinamikájával éppen arra a jelenségre utalok, hogy a közelebbi vizsgálat

\footnotetext{
${ }^{45}$ SólYOM László: Az alkotmánybíráskodás kezdetei Magyarországon. Osiris, Budapest, 2001, 397.

${ }^{46}$ SólyOM (45. lj.) 400-401.

47 7/2014. (III. 7.) AB határozat, Indokolás [42]; az Alaptörvény hatálybalépése után született e határozat tartalmilag a 30/1992. (V. 26.) AB határozat indokolásának V.1. pontjában foglalt értelmezést erősítette meg némiképp más megfogalmazásban.
} 
világos különbségek azonosítására vezet minket. Ezek a különbségek a dolgozat korábbi következtetéseivel szoros összhangban fogalmazhatók meg, újabb árnyalatokat helyezve a doktrína magyarázatába.

\subsection{A kereskedelmi szóláskorlátozás „szabadsága”}

Nézzük meg elöször, hogyan müködik a különleges védelem mechanizmusa abban a körben, ahol az alkotmányos szempontból legvédtelenebb közléseket, a kereskedelmi szólásokat találjuk. Ha azt gondoljuk, hogy a joggyakorlat ez esetben mellözi a különleges védettség hivatkozását, akkor tévedünk. Az 1270/B/1997. AB határozat azokat az indítványokat bírálta el, amelyek szerint az akkor hatályos reklámtörvénynek az a pontja, amely tiltja a személyhez füződő jogokat, valamint a kegyeleti és a személyes adatok védelméhez való jogot sértő reklámot, aránytalanul korlátozza a szabad véleménynyilvánítás jogát. Az Alkotmánybíróság a gazdasági reklámok alkotmányos helyének azonosításakor a szólásszabadságról kifejtett korábbi tételeit teljes vértezetükben idézi fel, a különleges jelentőség és kivételes korlátozhatóság felhívásával együtt. ${ }^{48}$ Mire azonban a testület az alapjog-korlátozás tesztjének tényleges alkalmazásához ér, az a szempont kerül a középpontba, hogy a kereskedelmi kommunikáció esetében szélesebb körü korlátozás lehet alkotmányos. A konkrét esetben ez azzal járt, hogy a határozat indokolása az alapjogi teszt alkalmazása körében megelégedett olyan, konkrét körülményeket valójában nem elemző kijelentésekkel, minthogy „a [reklámtörvény] azzal, hogy megtiltja a személyhez füződő jogokat, illetve a kegyeleti jogot sértő reklám közzétételét, az emberi méltósághoz való alapjog érvényesülése érdekében korlátozza a közlés szabadságát. $\mathrm{E}$ korlátozás a személyhez füződő jogok sérelmének megelőzése érdekében szükséges, és arányban áll a törvényhozó által elérni kívánt céllal, az egyén méltóságának védelmével”. Vagy még inkább: „[n]agyobb érdek füződik ugyanis a személyek

méltóságának védelméhez, mint a vélemények közlésének korlátlan szabadságához.” ${ }^{\text {} 49}$ A határozat indokolásában ezen kívül nem találunk szempontokat, amelyek a versengő jogokat a konkrét szabályozás tükrében, az alapul fekvő tényleges viszonyok figyelembevételével mérnék össze. Mindezzel nem a döntés érdemét vitatom, hanem a

\footnotetext{
48 1270/B/1997. AB határozat, Indoklás IV.1., ABH 2000, 713, 716.

${ }^{49}$ Uo., Indokolás IV.1., ABH 2000, 717. és Indokolás IV.2., ABH 2000, 718.
} 
mögöttes jogalkalmazói logikát szeretném érzékeltetni. Az Alkotmánybíróság valójában megelégedett a szólásszabadsággal szembeni jogok azonosításával, és nem látta szükségesnek, hogy az összeütközés feloldásához alkotmányos szempontokat, tételeket fogalmazzon meg. Másképpen fogalmazva: kijelölte az alkotmányos mérlegelés kereteit, de azon belül gyakorlatilag szabad kezet engedett a törvényhozónak. Ez a megközelítés megfelelően tükrözheti ugyan a kereskedelmi szólások alacsonyabb szintű védelmét, de a hivatkozások ellenére a „mérlegelésben” nyilvánvalóan nem biztosít különleges helyet a véleménynyilvánítás szempontjainak.

Még tanulságosabb e tekintetben a 23/2010. (III. 4.) AB határozat érvelése. Ez az indokolás az elbírált reklámkorlátozások rendkívül részletes elemzésével kulcsfontosságú szempontokkal gazdagítja a szólásszabadság doktrínáját a kereskedelmi kommunikáció alkotmányos helyének kijelölése terén. Nagy jelentőségü a határozat alkotmányellenességet megállapító része, amely a kereskedelmi kommunikáción már esetlegesen túlterjeszkedő előzetes korlátozást megsemmisítette. E helyütt azonban most az indokolásnak arra a jellegzetességére térünk ki, hogy abban a körben, ahol a testület pusztán kereskedelmi közlések korlátozására alkalmazta az alapjogi tesztet, ott még ez az egyébként gazdag érvelés is elhalkult. Arra gondolok, hogy a véleménynyilvánítás kitüntetett szerepének felhívása, majd ezt megszorítandó az üzleti beszéd alacsonyabb védettségének kifejtése után a határozat valójában a szóban forgó közlések alkotmányos státuszának meghatározásával végezte el a versengő jogok összeütközésének feloldását, és nem határozott meg a mérlegelés számára a szólásszabadságot védelmező szempontokat. Ehhez kétségtelenül hozzájárulhatott az a tény, hogy az ügyben dohánytermékek reklámozásáról kellett dönteni, amelyről a határozat kifejtette, hogy egészségkárosító hatására tekintettel még a kereskedelmi kommunikáción belül is a legkevésbé védett elemek közé tartozik. Akárhogy is, nekünk most ez a határozat áll rendelkezésünkre, és a beavatkozás súlyosságának mérlegelése körében ezúttal sem találunk fogódzót, ami a szólásszabadság érdekeit sikeresen védhetné az egyéb értékekkel szemben. Az indokolás megállapítása, mely szerint ,a szabályozás nem lehetetleníti el teljesen a kereskedelmi kommunikációt", 50 aligha tekinthető ilyennek. A dohányreklámokkal szembeni fellépést a közegészségügyi érdek és a kiskorúak érdeke önmagában, további arányossági körülmények felmerülése nélkül igazolta, és a véleménynyilvánítás

\footnotetext{
${ }^{50}$ 23/2010. (III. 4.) AB határozat, Indokolás VII.5.2., ABH 2010, 101, 142.
} 
alkotmányossági szempontjai teljes visszavonulót fújtak. Legalábbis nehéz másként olvasni az érvelés végkövetkeztetését: „Következésképpen az Alkotmánybíróság úgy foglalt állást, hogy a vizsgált tárgykör az Alkotmány 61 . §-a által legkevésbé védett közlések közé tartozik. A törvényi korlátozás szükségességét közegészségügyi célok és az állam egészségvédelmi kötelessége alapozza meg. A korlátozás arányosnak tekinthető, mert az üzleti célú kommunikációt érinti, és a közigazgatási jog intézményrendszerén belül érvényesül."

Még egyszer hangsúlyozom, hogy a fenti elemzés nem vitatkozik e határozatok végkimenetelével, de még csak az odáig vezető érvelés logikájával sem (utóbbi határozat esetében biztosan nem). A szólásszabadság-tesztek dinamikája körében mindössze annak demonstrálására kerítettünk sort, hogy a véleményszabadság kitüntetett helyének hüséges felemlegetése ellenére létezik a jog hatálya alá tartozó terület, ahol a versengő jogokkal, értékekkel szembeni mérlegelésben a törvényhozó rendkívül széles mozgástérrel és szabad beavatkozási lehetőséggel rendelkezik: a kereskedelmi kommunikáció eddig felmerült ügyeiben - felhívható legitim cél megállapítását követően - az Alkotmánybíróság nem gördített akadályt a jogalkotói fellépés szélessége elé. Érdemes megjegyezni, hogy a magyar gyakorlat ezzel az Emberi Jogok Európai Bíróságának esetjogához kapcsolódik, amelyet maga az Alkotmánybíróság összegzett úgy, hogy „,széles körü mérlegelési lehetőséget biztosít a tagállamoknak a reklámok korlátozása terén”, és ,egyezménykonformnak ítélt minden olyan korlátozást, amelyet a részes államok »mások jogai«, tehát a fogyasztók, vásárlók jogai érdekében alkalmaztak". 52 A reklámok terén - legyen szó akár tisztességes kereskedelmi gyakorlatról is - a beavatkozó állam koncepciója a tőle egyébként hagyományosan irtózó amerikai gyakorlatban is megtalálta a helyét. ${ }^{53}$

\footnotetext{
${ }^{51}$ Uo., Indokolás VII.6.3., ABH 2010, 145.

${ }^{52}$ Uo., Indokolás IV.3., ABH 2010, 120.

${ }^{53}$ Martin H. REDISH: Tobacco Advertising and the First Amendment. Iowa Law Review, Vol. 81., No. 3., 1996. 589-639.
} 


\subsection{A közvita kategorikus(abb) védelme}

\subsubsection{Megforduló vélelem a szólás szabadsága mellett}

A fentieket nyugodtan tekinthetjük a szólásszabadság-tesztek dinamikája egyik, a mérlegelést akár teljesen nyitva hagyó végpontjának. Ehhez képest teljesen más megközelítéssel találkozunk a szólásszabadság védettebb rétegeiben, mindenekelött a közéleti véleménynyilvánítás szférájában. E megközelítés legfontosabb jellemvonásait azonosíthatjuk a 7/2014. (III. 7.) AB határozatban. Az Alkotmánybíróságnak arról kellett döntenie, összhangban áll-e az alkotmányos követelményekkel a már elfogadott és kihirdetett, de még hatályba nem lépett új Polgári Törvénykönyv rendelkezése, mely szerint ,[a] közügyek szabad vitatását biztosító alapjogok gyakorlása a közéleti szereplő személyiségi jogainak védelmét méltányolható közérdekből, szükséges és arányos mértékben, az emberi méltóság sérelme nélkül korlátozhatja." ${ }^{„ 54}$ A határozat indokolása mindenekelőtt nemcsak alkotmányosan lehetségesnek, hanem kifejezetten szükségesnek ítélte, hogy a jogszabály bizonyos körben mérlegelési lehetőséget biztosítson a jogalkalmazóknak a politikai véleménynyilvánítás és a közszereplők személyiségvédelme összeütközésének feloldására. Az Alkotmánybíróság elismerte, hogy a kérdéskör szempontrendszerének összetettsége nem teszi lehetővé, hogy ö maga in abstracto teljes körüen meghatározza a releváns mércéket. ${ }^{55}$ Tekintettel arra, hogy a közéleti szereplők személyiségvédelmének korlátozottsága melletti érvek ereje nem teljesen egyforma az egyes érintett csoportok (például a közszereplő politikusok és az igazságszolgáltatást végző bírák) esetében, illetve még a politikusokkal kapcsolatban is maradnak értékelendő tényezők (például a magánélet érintettsége), a testület a „szükséges és arányos mértékben”, valamint „az emberi méltóság sérelme nélkül” kitételek által biztosított mérlegelési lehetőséget alkotmányosnak találta. A határozat indokolása azonban világossá teszi, hogy az egyes ügyekben ítélkező bírák mozgástere ebben a körben már korántsem kötetlen - sőt, valójában nagyon is kötött. Jól mutatja ezt, hogy az Alkotmánybíróság az absztrakt normakontroll során generális érvényü tételek és szempontok sokaságát határozta meg a jogalkalmazás számára.

\footnotetext{
${ }^{54}$ A Polgári Törvénykönyvröl szóló 2013. évi V. törvény 2:44. §-ának Országgyülés által elfogadott szövege.

55 7/2014. (III. 7.) AB határozat, Indokolás [52]-[53]
} 
Az Alkotmánybíróság egyrészt szigorú tételekkel szorította meg a hatályban tartott fordulatok értelmezését. Ilyen tételként fejtette ki mindenekelőtt, hogy „a közügyekkel összefüggésben megfogalmazott, közhatalmat gyakorló személyre vagy közszereplő politikusra vonatkozó, értékítéletet kifejező véleménynyilvánítás főszabály szerint polgári jogi felelősségre vonásnak sem lehet alapja”, illetve hogy az emberi méltóság felhívásának ebben a körben e jog korlátozhatatlan aspektusára kell szorítkoznia. ${ }^{56}$

Másrészt az Alkotmánybíróság a mérlegelési folyamat egészét alapvetően meghatározó kereteket szabott azzal, hogy a „méltányolandó közérdekböl” fordulatot alaptörvény-ellenesnek ítélte és megsemmisítette. Az egyedi ügy bírájának mozgásterét már az előbb említett tételek is szükítették, a testületnek ez a lépése azonban magát a mérlegelést, annak teljes szemléletét tereli eleve meghatározott mederbe. A határozat indokolása világossá teszi: a szólásszabadság szóban forgó, azaz közügyeket érintő megnyilvánulásai esetében nem az egyedi tényezők mérlegelésének függvénye, hogy igazolja-e a közléseket valamilyen (méltányolható) közérdek. „A közéleti véleménynyilvánítás alkotmányos sajátosságaiból következik, hogy a véleménynyilvánítás szabadságának a szabad társadalmi vitát szolgáló gyakorlása minden esetben nemcsak hogy »méltányolható közérdeknek«, hanem kiemelkedő jelentőségü alkotmányos érdeknek minősül. Ennek megfelelően a közügyek vitatása körében a közéleti szereplők személyiségi jogai védelmének a véleményszabadság gyakorlását biztosító korlátozása is minden esetben alkotmányos érdek és követelmény. Nincs tehát szükség további, közelebbröl nem körülírható »közérdeknek«, még kevésbé a közérdek »méltányolható« voltának igazolására ahhoz, hogy a közszereplők bírálhatóságára másoknál lényegesen szélesebb körben nyíljon lehetőség." 57

Azt láthatjuk tehát, hogy az Alkotmánybíróság a közügyek vitatását érintően sem vonja ugyan kétségbe bizonyos körben konkrét tényezők súlyozásának szükségét, a mérlegelés szemléletét mégis más szintre emeli: a szólásszabadság védelme nem az egyedi ügy változatos körülményeiben, hanem a szóban forgó közlések általános alkotmányos értékében gyökerezik. Ez az érték nem legyőzhetetlen, hiszen adott esetben e körben is sor kerülhet a véleményszabadság meghajlására más joggal, az emberi méltósággal szemben, ám az erre a következtetésre jutó bíró keze és - ami még

\footnotetext{
${ }^{56}$ Uo., Indokolás [61]-[62]

57 7/2014. (III. 7.) AB határozat, Indokolás [65]
} 
fontosabb - szemlélete a mérlegelésben jelentősen meg van kötve. Itt sincs tehát szó áttörhetetlen abszolutizmusról, de az egészen egyértelmü, hogy az eseti mérlegeléstől nagyon messzire kerültünk - oda, ahol a korlátozás dinamikáját már a kategorikusabb védelem logikája határozza meg. ${ }^{58}$ Mindezzel összhangban jellegadó sajátosságként emelhetjük ki azt is, hogy a közügyek vitája körében a versengő értékek mérlegelésének nézőpontja nem esetről esetre dől el, hanem alkotmányosan determinált: mindig a szólásszabadság kiemelt jelentősége felől kell megközelíteni és értékelni a felmerülő tényezőket. ${ }^{59}$ Így van ez akkor is, amikor a jogalkalmazó kivételesen azt állapítja meg, hogy a véleménynyilvánításnak engednie kell a korlátozására felhozott értékekkel szemben - döntése igazolása azonban nem alapulhat a mérlegelés eltérő szemléletén, hanem a doktrínához illeszkedő szigorú érveket kell tudnia felmutatni.

Míg az iménti határozat absztrakt normakontroll eljárásban valamennyi ügyre irányadóan tárta föl az eseti mérlegelésen túlmutató tételeket, addig az Alkotmánybíróság alkotmányos panaszok nyomán, konkrét tényállás ismeretében még tovább közelített a dinamika abszolutista végpontjához. Nem véletlen, hogy erre abban a körben került sor, ahol a közügyek vitájának szempontja a legközvetlenebb módon és legerősebben jelentkezik, mondhatnánk, „csúcsra van járatva”: a választási kampányban elhangzott közlések világában. Az 5/2015. (II. 5.) AB határozatban arról kellett dönteni, hogy a jogalkalmazók helyesen minősítették-e valótlan tényállításnak és így jogszerütlennek - az időközi országgyülési képviselőválasztás jelöltjének egyik kijelentését. A választási bizottság és a bíróság arra az álláspontra helyezkedett, hogy a „Fidesznek van 11 jelöltje, 11 különböző mezben” megjegyzés nem felel meg a

\footnotetext{
${ }^{58}$ Még nyilvánvalóbbá válik ez abból is, hogy egyes különvélemények pontosan emiatt támadták a határozat következtetéseit. Az egyik szerint indokolatlan volt a rendelkezés megsemmisítése, amely helyesen „valójában egy nyitott generálklauzula, amely esetről-esetre a bíróra bízza egyfelől a véleménynyilvánítás szabadsága és az emberi méltóságból fakadó személyiségi jogok, valamint a magánszféra alapjogi védelme közötti határvonal megvonását, másfelöl két személyiségi alanyi jog [Ptk. 2:42. § (1)-(2) bek.] összemérését, konfliktusuk elbírálását." (Lenkovics Barnabás alkotmánybíró különvéleménye, Indokolás [108]). A másik szerint szintén az eseti jogalkalmazókra kellett volna bízni a törvényi fordulat tartalommal való megtöltését (Salamon László alkotmánybíró különvéleménye, Indokolás [123])

${ }^{59}$ Más különvélemények pedig a döntésnek épp ezt a következményét, tételét domborítják ki, vitatkozva is hozzájárulva a doktrína tisztázásához. Az egyik szerint a határozat „fordított elöjellel közelítette meg az alapvető alkotmányossági problémát. Jelen esetben ugyanis éppen nem a sajtószabadság, illetve a véleménynyilvánítás korlátozása a kiinduló pont, hanem az emberi méltóság védelme, illetve annak korlátozhatósága." (Balsai István alkotmánybíró különvéleménye, Indokolás [77]). A másik szintén nem ért egyet azzal, hogy ,[a] többségi határozat egyik sarokpontja, hogy a közéleti szereplők személyiségi jogvédelme esetén az alkotmányos védelem középpontjában a közügyek megvitatása során kifejtett vélemények állnak, nem pedig a véleménynyilvánítással érintett személyek emberi méltósága.” (Juhász Imre alkotmánybíró különvéleménye, Indokolás [93])
} 
valóságnak, hiszen a pártok egyetlen jelölttel indulnak az egyéni választókerületben. Az Alkotmánybíróság ezt a formális érvelést elutasítva arra helyezte a hangsúlyt, hogy a közlés minősítése nem egyes kiragadott elemek formális tényszerüségén múlik, hanem azon, hogy összességében a választópolgárok által értelmezhető értékítéletet, véleményt mondott arról, hogy az induló jelöltek többségét „kamujelöltnek” tartja. Az indokolás a kijelentés értékelése kapcsán rámutatott arra, hogy ,[v]álasztási kampányban tipikusan a közszereplők egymás közti kontextusában kell értelmezni és megítélni a véleménynyilvánítási szabadságot, illetve annak korlátait. Ez mindenekelött annyit jelent, hogy az egymással versengő jelöltek igyekeznek előnyt szerezni, s ennek elérése érdekében nyíltan és akár kendőzetlenül is megnyilvánulhatnak. Társadalmi érdek, hogy a kampányban nemcsak a közügyeket, hanem az egyes jelöltek alkalmasságát és a jelölö/támogató szervezet programját is megvitassák. (...) A jelen ügyben vizsgált bírói döntés ugyanakkor megragadva a kijelentés direkt tartalmánál, nem vette figyelembe, hogy az indítványozó véleményként fejtette ki mondandóját." ${ }^{\text {60 }} \mathrm{Az}$ Alkotmánybíróság tehát alaptörvényellenesnek ítélte azt a jogalkalmazói módszert, amely egyes tényállási elemek kiragadásával („megragadva a kijelentés direkt tartalmánál”) háttérbe szorítja a választási kampány felfokozott vitájának szabadságát. A testület nem ment bele abba, hogy az ügy körülményeit szenvtelen, formális vizsgálatnak vesse alá, hanem a közügyek vitájának egyik legbelső szférájában nagyon határozottan érvényesítette a szólásszabadság szempontjait.

Még markánsabban mutatkoznak meg az elmondottak a 9/2015. (IV. 23.) $A B$ határozat körülményei között. Az ügy alapjául szolgáló kampányvideóban az ajkai időközi választás támadott jelöltjéröl az hangzott el, hogy fajsúlyos szerepe volt a vétkes cég (Mal Zrt.) tevékenységében, mivel az ominózus vörösiszap-katasztrófa idején „ott ült a cég vezetői között” és ,az ö dolga lett volna, hogy megakadályozza a katasztrófát, de ő semmit sem tett”. Az eljáró bíróság a kijelentésben olyan súlyú valótlan tényállítást azonosított, amely az érintettet súlyos büncselekmény elkövetésével vádolja. A támadott jelölt ugyanis csupán a cég felügyelőbizottsági tagja volt, így nem terhelte őt a videóban sugalmazott felelősség. Az Alkotmánybíróság ezzel szemben jelen esetben is a szólásszabadság szempontjait ítélte erősebbnek, és különösen tanulságos számunkra a döntés lakonikus indokolásából kitünő szemlélet. A

\footnotetext{
${ }^{60}$ 5/2015. (II. 5.) AB határozat, Indokolás [26]-[27]
} 
testület valójában nem is ment bele annak részletes elemzésébe, hogy milyen szempontok szólnak az érintett közlés átminősítése (ti. tényállításból értékítéletté) mellett, hanem megelégedett annak hangsúlyozásával, hogy a választási kampányok felfokozott diskurzusáról van szó. Legalábbis nem olvasható ki más a határozat szövegéből, amely szerint ,az Alkotmánybíróság azt állapította meg, hogy a választási kampány során közzétett videó és annak közlései egyértelmüen a véleménynyilvánítás szabadságának fokozott védelmét élvező közügyek szabad vitatásának fogalmi körébe tartoznak”, „a jelölő szerv indítványozó által képviselt városi szervezete politikai véleményként tette közzé a videót egy választási kampány során”, ebből következően „értékítéletet közvetített, amely nem az ellenérdekelt jelölt büntetőjogi felelősségre vonására irányult". ${ }^{61}$

A fenti ügyekböl kiviláglik a közügyek vitájának körében domináló, a szólásszabadság felől közelítő szemlélet egyik fontos ismérve, ami más tényállások esetén esetleg kevésbé feltünő: az alkotmányossági vizsgálat dinamikája ez esetben valójában a korlátozás alaptörvény-ellenességének vélelmére épült. A vélelem megdönthető ugyan, de a skála abszolutista pontjához közeledve (például a választási kampányok során) egyre kisebb mozgástere van erre jogalkotóknak és jogalkalmazóknak. ${ }^{62}$ Vegyük észre, hogy ez a szemlélet kivételes, és eltér attól a főszabálytól, amely a jogrendszer - esetünkben most a jogszabályok és a bírói döntések - alkotmányosságából indul ki. Fontosnak tartom tisztázni: nem gondolom, hogy a hagyományos értelemben vett, a szóban forgó indokolásokban expressis verbis alkalmazandó olyan jogi vélelemmel állunk szemben, amely az ismert intézményi sajátosságokat hordozza. A most azonosított jellemzők sokkal inkább a határozatok érvelésének mögöttes logikájából kiolvasható iránymutatások, amelyeknek a szólásszabadság ügyeiben döntők szemléletét kell meghatározniuk.

Hogy nem csupán a választási szólásszabadság specifikumáról beszélünk, arra egy korábbi döntés is rámutat. A 95/2008. (VII. 3.) AB határozatra azért is érdemes kitérnünk, mert a hozzá csatolt egyik különvélemény épp a benne foglalt abszolutista szemléletet kritizálta. ${ }^{63}$ Míg azonban a döntést abszolutizmussal vádolni tévedés, addig

\footnotetext{
${ }^{61}$ 9/2015. (IV. 23.) AB határozat, Indokolás [43]

${ }^{62}$ Megdőlt például a vélelem, amikor a kampányba indokolatlanul kevertek magánéleti viszonyokat [3100/2017. (V. 8.) AB határozat]. Életszerütlen módon megdőlni látta a vélelmet az Alkotmánybíróság akkor is, amikor egy kampányfilm a miniszterelnök-jelölteket majmokhoz hasonlította [3122/2014. (IV. 24.) AB határozat]

${ }^{63}$ Kiss László alkotmánybíró különvéleménye, II.1. és II.3.
} 
valóban megfigyelhető rajta a szóláskorlátozások kategorikusságot is ismerő szemlélete. Mivel az üggyel a dolgozat korábbi fejezetei is foglalkoztak, e helyütt kizárólag az e dinamikát érintő következtetés levonásának erejéig térünk rá vissza. A határozat tanúsága szerint a gyülöletbeszédnek az uszítás szintjét el nem érő megnyilvánulásai körében helye van kategorikus alkotmányos kijelentések megfogalmazásának. Az alkotmánybírósági gyakorlat fősodrát összegző indokolás lényegét tekintve arra utal, hogy a társadalmi vitában - nem személyre szabottan elhangzó gyalázkodások, sértegetések körében a véleménykorlátozás alkotmányellenességének vélelmével állunk szemben. Ennek megdönthetetlenségét korábbi határozatok tükrében nem is lehetett volna állítani, ${ }^{64}$ de a versengő jogok és értékek mérlegelésének kötelező szemléletét a többi tézissel összhangban erősítette meg az Alkotmánybíróság. Ahhoz, hogy a szólásszabadság alulmaradjon, olyan többlet-körülményre van szükség, ami határozottan kimozdítja a mérlegelést a szokásos medréből, például azzal, hogy az egyébként általánosító gyalázkodás problémáját kifejezetten a támadott csoport tagjait célzó, számukra kitérést nem hagyó helyzetben veti föl. ${ }^{65}$

Végezetül érdemes a 3/2015. (II. 2.) AB határozattal zárni elemzésünket, mivel abból a szólásszabadság-védelem dinamikájának egész szempontrendszere bontható ki. Az ügy sajátosan összetett körülményei nemcsak a kereskedelmi és a közéleti szólások elkülönítése számára hordoznak kulcsfontosságú tanulságokat, ${ }^{66}$ hanem a tekintetben is, hogy a besorolástól függően miként változik meg az alkotmányossági vizsgálat szemlélete. Az alapul fekvő ügyben született közigazgatási határozat, valamint az azt helybenhagyó bírósági döntés a gazdasági lap újságcikkének közzétételével megvalósuló piacbefolyásolást egynek tekintette a törvényi tilalom tényállásába illeszkedő sokféle magatartás közül, és a versengő értékek mérlegelését nagy szabadsággal végezte el. Így juthatott el a törvényi definíció kiterjesztő értelmezésével annak generális megállapításához, hogy a tőkepiacok zavartalan működését valós információt közlő sajtócikk is megvalósíthatja, majd az egyedi ügy körülményeit ennek figyelembevételével értékelve lehetőséget látott a sajtószabadság korlátozására.

\footnotetext{
64 A gyakorlat ismertebb kivételei: a 13/2000. (V. 12.) AB határozat a nemzeti jelképek meggyalázásáról, a 14/2000. (V. 12.) AB határozat a tiltott önkényuralmi jelképekröl, a 16/2013. (VI. 20.) AB határozat a diktatúrák rémtetteinek tagadásáról.

65 95/2008. (VII. 3.) AB határozat, Indokolás III.3.1-3.4.

${ }^{66}$ Ezek kifejtésére lásd: TöRÖK Bernát: Alkotmányjogi tesztek hálójában. A sajtószabadság esete a tőkepiaccal. In: FEJES Zsuzsanna - TÖRÖK Bernát (szerk.): SUUM CUIQUE. Ünnepi tanulmányok Paczolay Péter 60. születésnapja tiszteletére. Szeged, Pólay Elemér Alapítvány, 2016
} 
Az Alkotmánybíróság azonban gyökeresen átrajzolta a mérlegelés alkotmányos kereteit. A testület a jogesetet a közügyek vitájának szempontrendszerébe emelte, és világos elvi határokat szabott a mérlegelésnek. Eszerint a szóban forgó alkotmányos értékek versengését annak szem előtt tartásával kell és lehet csak feloldani, hogy a sajtószabadság e körben kitüntetett szereppel bír. A sajtó tájékoztató tevékenységére vonatkozó törvényi korlátok, köztük a tökepiaci törvény érintett rendelkezésének „értelmezésekor mindig úgy kell eljárni, hogy a sajtó alkotmányos küldetésének teljesítését, a közérdeklődésre számot tartó információk közzétételét ne akadályozzák vagy hátráltassák."67 Míg tehát a közigazgatási hatóság és a bíróság az alkotmányos értékek ütközését az egyedi ügy körülményeinek $a d$ hoc súlyozásával oldotta föl, addig az Alkotmánybíróság határt szabott a mérlegelésnek, kijelölve a sajtószabadságnak azt az értelmezési tartományát, amely védett területnek számít. A közvéleményt valós információkkal ellátó média működését - ha nem is abszolút, de - kategorikusabb védelem illeti meg, amelyet a tőkepiacok zavartalan müködése csak nagyon szük körben, kivételesen törhet át - akkor, amikor a sajtó rosszhiszemüen, kifejezetten félrevezető vagy megtévesztő szerkesztéssel tárja a közönség elé az információkat. ${ }^{68}$

A határozat egyszersmind arra is rámutat, miért is olyan fontos, hogy a szólás- és sajtószabadság korlátjainak értékelésekor figyelemmel legyünk az alkotmányos védelem dinamikájára. A versengő alkotmányos értékek és alkalmazandó mércék köre ugyanis szituációtól függően változhat, még maga a közéleti véleményszabadság sem homogén közeg - a most elemzett dinamika azonban állandó iránytüje az alkotmányos vizsgálatnak. Az Alkotmánybíróság a jelen esetben is elismerte a szóba jövő speciális versengő érték relevanciáját, amikor a tőkepiacok külső befolyástól mentes zavartalan müködését az Alaptörvény alapján olyan legitim szabályozási célnak tekintette, amely a sajtó tájékoztató tevékenységének is korlátja lehet. A testület iránymutatása tehát figyelemmel volt arra, hogy a gazdasági újságírás sajátos gazdasági érdekeket érinthet. A jogalkalmazás ezeket számításba veheti. A sajtószabadság védelmét ugyanakkor nem gyengítheti a kereskedelmi szólások tesztjének szintjére, hanem a közügyekre fókuszáló dinamika szerint kell eljárnia. Az alkotmánybírósági határozat ennek szellemében bástyázta körbe a kategorikusabban védett területet, megfogalmazva azt a követelményt, hogy a sajtó alkotmányos küldetésére tekintettel a tájékoztatás

\footnotetext{
${ }^{67}$ 3/2015. (II. 2.) AB határozat, Indokolás [25]

${ }^{68}$ Uo., Indokolás [28]-[29]
} 
szabadsága nem csorbítható addig a mértékig, hogy az az egyébként valós (releváns tényekkel alátámasztott) információk nyilvánosságra hozását akadályozza.

\subsubsection{Jogági különbségek relativizálódása}

Az alaptörvény-ellenesség vélelmének megjelenése - és akár felerősödése - mellett van még egy fontos jellemvonása a most elemzett dinamikának, ami azzal a kérdéssel áll összefüggésben, hogy a szólásszabadság korlátozásakor mekkora jelentősége van az alkalmazott eszközök jogági besorolásának. Mércéinek specialitása miatt a médiajogi szabályozást most nem érintve mindenekelőtt arra a klasszikus dilemmára érdemes kitérnünk, hogy milyen különbségek adódnak egy büntetőjogi és egy polgári jogi korlátozás megítélésében.

A kiindulópont e tekintetben teljesen egyértelmünek tünik: az Alkotmánybíróság lényeges, adott esetben perdöntő tényezőnek tekinti a beavatkozás jogági jellegét. Egyrészt a büntetőjogot - judikatúrájának általános formulájaként - a véleménynyilvánítás szabadságát érintő ügyekben is olyan ultima ratioként azonosítja, amelynek „szerepe és rendeltetése a jogi és erkölcsi normák épségének fenntartása akkor, amikor már más jogágak szankciói nem segítenek". ${ }^{9}$ Másrészt még beszédesebb a 30/1992. (V. 26.) AB határozat szólásszabadság-specifikus formulája, amely aztán a joggyakorlat többször visszatérő érve lett: a nagy nyilvánosság előtt folyó közéleti vitához hozzátartozhat, hogy „számolni kelljen magas kártérítésekkel. Büntetőjogi büntetésekkel azonban nem a közvéleményt és a politikai stílust kell formálni - ez paternalista hozzáállás -, hanem más jogok védelmében az elkerülhetetlenül szükséges esetekben szankcionálni”, ${ }^{70}$

Ezekből az alapvetésekből akár az is következhetett volna, hogy az Alkotmánybíróság - noha a büntetőjog mint ultima ratio bevetésétől jellemzően elzárja a jogalkotót - a polgári jogi fellépés vonatkozásában sokkal megengedőbb hozzáállást tanúsít. A doktrínát e tekintetben meghatározó döntések azonban nem erre utalnak. Kétségkívül disztingváltabb, a polgári jog eltérő logikáját figyelembe vevő

\footnotetext{
${ }^{69}$ Elsőként lásd a 30/1992. (V. 26.) AB határozatot, Indokolás IV.4., ABH 1992, 167, 176.; később idézte pl. 12/1999. (V. 21.) AB határozat, Indokolás III.2., vagy 18/2004. (V. 25.) AB határozat, Indokolás V.2.2.

70 30/1992. (V. 26.) AB határozat, Indokolás V.3., ABH 1992, 167, 180.; átvette: 36/1994. (VI. 24.) AB határozat, Indokolás III.2., illetve 18/2004. (V. 25.) AB határozat, Indokolás V.2.2.
} 
megközelítést olvashatunk ki belölük, a végeredmény tekintetében ugyanakkor a büntetőjogi határozatokhoz hasonló egyhangúságot mutatnak: az Alkotmánybíróság rendre megsemmisítette a közügyek vitáját korlátozó új rendelkezéseket. Ezek a döntések annyiban disztingváltabbak, amennyiben sok esetben nem zárják ki eleve, hogy a jogalkotó a vizsgált jogintézményeket valamilyen formában újraszabályozza, az „élet” mégis mindig úgy hozta, hogy az Alkotmánybíróság elé került konkrét megoldások nem élték túl az alkotmányossági vizsgálatot.

Ez történt az 57/2001. (XII. 5.) AB határozattal elbírált válaszadási jog esetében. Az Alkotmánybíróság elöször is megállapította, hogy a büntetőjog logikájához képest sajátos szempontra, a közvélemény minél szélesebb alapú formálására tekintettel „a tág értelemben vett válaszadás joga általában a véleménynyilvánítás és a sajtó szabadságának nem alkotmányellenes korlátozása". ${ }^{71}$ A konkrét szabályozási megoldást vizsgálva azonban a testület már arra jutott, hogy az nem teremtett egyensúlyt az emberi méltóság és a jóhírnév védelmét szolgáló új jogintézmény, valamint a közéleti vitákban gyakorolt szólás- és sajtószabadság között, indokolhatatlan mértékben korlátozva az utóbbit. Az Alkotmánybíróság ugyanis a polgári jogi beavatkozás vizsgálata során is azt hangsúlyozta, hogy „a korlátozás alkotmányosságának a megítélésénél a kiindulási pontot a véleménynyilvánítás és a sajtó szabadságának a demokratikus rendszer fenntartásában, a közösség tájékoztatásában és a közvélemény kialakulásában játszott különösen fontos szerepe jelenti. Ez a szerep előtérben áll és ezért e szabadságjogok korlátozása szük körben lehetséges olyankor, ha politikai vitáról, az állam bírálatáról van szó”. 72

Hasonlóképpen járt el az Alkotmánybíróság a közösségeket sértő beszéd egyéni személyiségi jogsértést eredményező ,átsugárzását” elismerő új jogintézmény vizsgálatakor is. A 96/2008. (VII. 3.) AB határozat nem zárta ki, hogy igen szük körben - amikor is „a véleménynyilvánítás a közösség egészére vonatkoztatott, a közösség tagjainak megkérdőjelezhetetlen, lényeges tulajdonságával áll összefüggésben, és akár a közösség létét is megkérdőjelezően szélsőséges” - az „átsugárzás” jogvédelmet igazolhat. ${ }^{73}$ Ennek ellenére a testület az előtte fekvő konkrét megoldást ezúttal is alkotmányellenesnek találta, mivel megengedhetetlenül súlyos következményeket kapcsolt az esetleges jogsértéshez. A határozat indokolása szerint

\footnotetext{
${ }^{71}$ 57/2001. (XII. 5.) AB határozat, Indokolás II.11., ABH 2001, 484, 498.

${ }^{72}$ Uo., Indokolás II.8., ABH 2001, 494.

73 96/2008. (VII. 3.) AB határozat, Indokolás III.3., ABH 2008, 816, 824.
} 
az akár többszörös kényszerü alperesi pozíció és nyilvános elégtételadási kötelezettség, illetve a bírói mérlegeléstől függő kártérítés mint anyagi jellegü szankció a véleménynyilvánítás szabadságának indokolatlan korlátozását jelenti. Az Alkotmánybíróság azzal együtt találta aránytalannak a szólásszabadsággal szembeni fellépés lehetőségét, hogy most sem mulasztotta el tisztázni: a polgári jogi szankciók a jogrend felelősségi rendjében nem minősülnek ultima rationak. ${ }^{74}$

A véleményszabadság korlátozásának arányossága és a polgári jogi szankciók közötti érzékeny kapcsolat nyilvánvalóvá válik ezekből az ügyekböl. A 19/2014. (V. 30.) AB határozat ennek nyomán általánosító jelleggel fogalmazhatta már meg, hogy „a személyiségi jogsértésekért megállapított kártérítések esetében is irányadók a véleménynyilvánítás (benne a sajtó) szabadságának korlátozásával kapcsolatos alkotmányos szempontok, amelyek a vélemény szabadságának és az egyén jogainak megfelelő egyensúlyát kívánják meg”, figyelembe véve a közszereplők bírálhatóságának nagyobb szabadságát is. ${ }^{75}$ Azt gondolom, annyit már ezek után a határozatok után levonhatunk: igen messzire kerültünk attól az imént idézett elnagyolt megjegyzéstől, mely szerint - bár a büntetőjogi beavatkozások esetében komoly alkotmányossági kihívásokkal kell szembenéznie a törvényhozónak - az már hozzátartozhat a közvélemény formálódásának folyamatához, hogy „számolni kelljen magas kártérítésekkel”.

Ha pedig még tovább vizsgáljuk a kérdést, akkor ráadásul a korlátozás arányosságának kérdésköréböl is némiképp kilépve a kategorikusabb védelem egyik jellemvonásához érkezünk. Érdemes ebből az aspektusból is szemügyre vennünk az egyik „nagy klasszikus” polgári jogi kérdés, a közéleti szólásszabadság és a személyiségvédelem ütközésének szempontjait elemző 7/2014. (III. 7.) $A B$ határozatot. Az Alkotmánybíróság e határozat indokolásában témánk szempontjából nagyon fontos tisztázást tett: a polgári jogi megoldások kialakításánál sem pusztán arról van szó, hogy a törvényhozó esetleg aránytalan korlátozásokra ragadtatja magát, hanem arról is, hogy a kategorikusabb védelem alá tartozó zónák felé haladva a beavatkozás e jogág számára is egyre inkább eleve tiltott. A közügyek vitájának kiemelt alkotmányos jelentősége, a sajtó alkotmányos küldetése a tájékoztatásra, a polgárok minél szabadabb részvétele a társadalmi-politikai eszmecserében (benne a

\footnotetext{
${ }^{74}$ Uo., Indokolás IV.1.2., ABH 2008, 830.

75 19/2014. (V. 30.) AB határozat, Indokolás [66]
} 
közéleti szerepet vivők ellenőrzésében) mind-mind olyan alkotmányossági követelmények, amelyek nemcsak a büntetőjogi felelősségre vonás, hanem a polgári jogi jogkövetkezmények tekintetében is irányadók. A büntetéseken túl ugyanis a kártérítések, sérelemdíjak „szélesre tárt lehetősége szintén komoly visszatartó erőt jelenthet a közvitában való részvételtől". ${ }^{76}$ Annak a megfontolásnak az érvényessége sem korlátozódik a büntetőjogra, hogy a demokratikus jogállami intézmények és a közéletet alakító politikusok bírálata az állampolgároknak és a sajtónak olyan alapvető joga, amely a demokrácia lényegi eleme. Az e körben megfogalmazott, értékítéletet tartalmazó véleménynyilvánítás esetében ezért főszabály szerint eleve nincs helye jogi elégtétel követelésének, így polgári jogi felelősségre vonásnak sem. ${ }^{77}$

Vegyük észre, hogy jóval többről van itt már szó, mint puszta arányossági kérdésről. Az Alkotmánybíróság azt tette egyértelművé, hogy a kategorikusabb védelem szférái - az őket igazoló érvek és alkotmányossági szempontok általános érvénye miatt - a polgári jog számára sem jelentenek szabadabban szabályozható területet. Ez a következtetés nemhogy nem meglepö, hanem egyenesen szükségszerü, ha arra gondolunk, hogy mindez a szólásszabadság esetében értelmesen körvonalazható „lényeges tartalom” fogalmán nyugszik. Márpedig a lényeges tartalom minden jogág számára az. ${ }^{78}$

Az absztrakt normakontroll eljárásokban kidolgozott fenti tételek - alkotmányjogi panaszok nyomán - ma már konkrét tényállások kapcsán is életre kelnek az Alkotmánybíróság gyakorlatában. Nagyon tanulságos e tekintetben a 3001/2018. (I. 10.) $\mathrm{AB}$ határozat, amely személyiségi jogi perben vizsgálta a szólásszabadság nyújtotta védelem határait. A testületnek arról kellett döntenie, az Alaptörvénnyel összhangban állapították-e meg az eljáró bíróságok, hogy egy történészek közötti vitában az egyik szakértőnek a másik kijelentésére megfogalmazott, heves és túlzó reakciója nem minősült hírnévrontásnak. A tényállás sajátos súlyt adott a kérdésnek azáltal, hogy a vita tárgya egy eseménynek a holokauszt körébe sorolhatósága volt, ami arra vezetett, hogy a panaszos által kifogásolt mondatok a holokauszthoz való teljes hozzáállását megkérdőjelezték és megbélyegezték. Világos volt, hogy a téma

\footnotetext{
76 7/2014. (III. 7.) AB határozat, Indokolás [48]

${ }^{77}$ Uo., Indokolás [61]

${ }^{78}$ Talán nem félreértés a részemről, ha az arányossági vizsgálat ilyen értelemben vett meghaladásában Sólyom Lászlónak a lényeges tartalommal összefüggésben kifejtett gondolatát látom igazolódni, mely szerint a szólásszabadsággal kapcsolatban levezetett ismérvek némelyike „módszertanilag túlmutat eddigi alkalmazási területén". Lásd a 46. lábjegyzetet.
} 
érzékenysége miatt a jó hírnév sérelmének kérdése ebben az esetben minősített módon, akár a „karakter-gyilkosság” erejével is felmerülhet. Az Alkotmánybíróság határozatának indokolása mutatja, hogy a testület ennek tudatában igen körültekintően elemezte a releváns alkotmányossági követelményeket, és végül a szólásszabadság javára döntött. Ami számunkra különösen érdekes most ebben a határozatban, hogy egy rendkívül kiélezett helyzetben az Alkotmánybíróság a véleménynyilvánítás védelmének kategorikusabb értelmezésébe kapaszkodott: arra tekintettel, hogy az érzékeny ügy kifogásolt állítása végeredményképpen minden elemében (tárgya, kontextusa, elhangzásának körülményei alapján is) a közügyek vitájának körében maradt, „nem került a szólásszabadság védelmi körén kívülre”, és elsőbbséget élvezett az érintett közszereplőt ért esetleges sérelmekkel szemben. A határozat megerősíti, hogy bár adott esetben az ilyen szólások is elveszíthetik védettségüket, ahhoz különleges körülményekre - az emberi méltóság legbensőbb magjának sérelmére, öncélú megalázásra vagy a magánéletbe hatolásra - van szükség. ${ }^{79}$ A véleményszabadság különösen védett körének határai tehát a polgári jogi igények érvényesítése elé is nehezen áttörhető falat emelnek.

Mindezzel egyáltalán nem állítom a jogági különbségek jelentéktelenségét vagy teljes szerepvesztését, pusztán azok relativizálódására szeretném felhívni a figyelmet. Nyilvánvaló, hogy a polgári jog sajátos logikájából és dogmatikájából, illetve az arányosság szempontjából nagyobb mozgásteret engedő természetéből bizonyos esetekben akkor is születhet korlátozás, amikor a büntetőjog szigorának már nem jut hely. Mindez azonban nem írja fölül a szólásszabadság védelmének dinamikáját, amely a jogrendszer egészére szóló érvénnyel bír - a lényeges tartalom védelmének kategorikussága így a polgári jog számára is határt szab.

\footnotetext{
${ }^{79}$ 3001/2018. (I. 10.) határozat, Indokolás [39]
} 


\section{Következtetések}

1. A szólásszabadság gyakorlatának gazdagsága, a mérlegelendő körülmények változatossága a jogi tesztek alkalmazhatóságát behatárolja. Az ügyek megoldását segítő egyes formulák helyes alkalmazásához mindenekelőtt figyelemmel kell lennünk a szólások korlátozásának dinamikájára, vagyis a beavatkozás mozgásterét meghatározó alapvető összefüggésekre.

2. A szólásszabadság védelmének dinamikája a védelem abszolutisztikus, kategorikus formájától a versengő jogokkal és értékekkel való eseti mérlegelésig terjedő skálával írható le.

3. A magyar alapjogi dogmatikától nem idegen az eseti mérlegelésen túlmutató alapjogi védelem gondolata: kivételesen, kiemelt védelemben részesített alapjogokkal kapcsolatban sor kerülhet arra, hogy az alapjog lényeges tartalmának relatív meghatározását tartalmi jegyek megadásával törjük meg.

4. A szólásszabadság dogmatikájában a kategorikusabb védelem logikájának is helye van, mivel egyértelműen rendelkezik az ehhez szükséges két fogalmi elemmel: mind az alapjog kiemelt védettsége, mind lényeges tartalmának megragadhatósága megkérdőjelezhetetlen.

5. Bár a véleményszabadság kitüntetett helyéről szóló tételeket a gyakorlat e jog teljes hatálya alatt felhívja, egyes területeken - különösen a kereskedelmi kommunikáció terén -a versengő jogokkal, értékekkel szembeni mérlegelésben a törvényhozó rendkívül széles mozgástérrel rendelkezik.

6. A közügyek vitájában a szólásszabadság védelme nem az egyedi ügy változatos körülményeiben, hanem a szóban forgó közlések általános alkotmányos értékében gyökerezik, és kategorikussá válik. Ebben a körben a versengő értékek mérlegelésének nézőpontja nem esetről esetre dől el, hanem alkotmányosan determinált: mindig a szólásszabadság kiemelt jelentősége felől kell megközelíteni és értékelni a felmerülő tényezőket.

7. A közügyek vitájának körében domináló szemlélet egyik fontos ismérve a joggyakorlatban, hogy az alkotmányossági vizsgálat ez esetben valójában a korlátozás alaptörvény-ellenességének vélelmére épül. 
8. A versengő alkotmányos szempontok köre szituációtól függően változhat, de a szólásszabadság kategorikusabb védelemmel körülbástyázott területét nagy szigorral kell oltalmazni.

9. A lényeges tartalom védelmének kategorikussága a jogrendszer egészére szóló érvénnyel bír. 


\section{ZÁRSZÓ}

A dolgozatban azoknak a téziseknek a tartalmát, értelmét igyekeztem megragadni, amelyek úgy adják a szólásszabadság magyar doktrínájának alapjait, hogy súlyukhoz képest különösen is zavaró homály veszi öket körül. Vizsgálódásunk sok részeredményt hozott és fontos következetések levonásához vezetett, mégsem akarom azt állítani, hogy kristálytiszta vidékre érkeztünk volna. Bőven maradtak nyitott kérdések. Ha azonban csak kis mértékben is sikerült meggyőzően érvelnem, akkor a zárszóhoz érve talán világosabban látszik: ez a lezáratlanság már minőségileg más állapot, mint a kezdeti homályosság. A bizonytalanság csak látszólag közös elem bennük, mert nem sok közös van a reménytelen bukdácsolás és a szilárd fogódzókba kapaszkodó körültekintő előrehaladás között. Öszintén hiszem, hogy a dolgozat gondolatai összességében az utóbbihoz vittek minket közelebb.

Minden érintett kérdéskörnek megvoltak a maga következtetései, amelyeket az egyes fejezetek végén külön-külön összefoglaltam. Munkám legfontosabb tanulságának ugyanakkor azt tartom, ami ezeknek a következtetéseknek közös gyökere: a szólásszabadság dogmatikai kérdéseinek tisztázása mindenekelőtt abban segít minket, hogy helyesen lássuk jogászi döntéseink tétjét, célját, értelmét. Zárszóként összefoglalva ennek a szemléletnek a két legfontosabb pillérjét, egyrészt azt igyekeztem hangsúlyozni, hogy jogértelmezéseink csak akkor állhatnak össze értelmes és koherens doktrínává, ha azok alapját és iránytüjét körültekintően tisztázott és érzékenyen szem előtt tartott alkotmányos értékek, célkitüzések jelentik. Másrészt annak demonstrálására törekedtem, hogy egy, a körülöttünk lévő valósággal oly érzékeny kontextuális kapcsolatban lévő szabadságjog, mint a véleménynyilvánítás esetében sosem lesznek a kezünkben mindentudó jogi formulák, amelyek megoldják helyettünk társadalmi jelenségeink értékelését. Nem a dogmatika alábecsülése ez, hanem kötöttségeinek elismerése és valódi értelmének feltárása. Nem arra van szükségünk, hogy önmagukba zárt szempontokból próbáljunk összességében vak szabályrendszert eszkábálni, hanem arra, hogy alkotmányos tesztjeinket és érveinket a lényegre fókuszáló doktrínává illesszük össze. Reményeim szerint a dolgozat a megfoghatóbb, gyakorlatiasabb következetéseken túl ezt a mélyebb összefüggést is hitelesen csatornázta be a tudományos diskurzusba. 
Meggyőződésem, hogy a jogtudomány csakis ezeknek az alapoknak a tisztázásával szerezhet esélyt arra, hogy a véleménynyilvánítás jogának sokrétü és folyton megújuló erővel hömpölygő kihívásaira megfelelő válaszokat tudjon adni. Olyan válaszokat, amelyek nem roppantják össze a szólás mindig törékeny szabadságát. ${ }^{1}$ A tét változatlan: demokráciánk müködése. Egy kísérletet tehát biztosan megért a tisztázás.

\footnotetext{
${ }^{1}$ Mert ahogy Sajó András írja: „A szólásszabadság törékeny jószág, szinte vakszerencse alkotta mandala." SAJÓ András: (Ön) cenzort akarunk! Élet és Irodalom L. évfolyam 14. szám, 2006. április 7.
} 


\section{FELHASZNÁLT FORRÁSOK}

\section{Irodalomjegyzék}

ÁDÁM Antal: Alkotmányi értékek és alkotmánybiráskodás. Budapest, Osiris, 1998

AleINIKOFF, T. Alexander: Constitutional Law in the Age of Balancing. 96 Yale Law Journal 943 1986-1987

BAKER, C. Edwin: Harm, Liberty, and Free Speech. 70 Southern California Law Review 979 1996-1997

BAlKIn, Jack M.: Cultural Democracy and the First Amendment. 110 Northwestern University Law Review 10532016

BALKIN, Jack M.: Old School/New School Speech Regulation. 127 Harvard Law Review 22962014

BARENDT, Eric: Freedom of Speech. Oxford-New York, Oxford University Press, 2005

BAYLeS, Michael D.: Mid-Level Principles and Justification. In: J. Roland Pennock and John W. Chapman (szerk.): Justification. New York and London, New York University Press, 1986

BENTHAM, Jeremy: On the liberty of the press and public discussion. In: Works of Jeremy Bentham, vol. II. (ed. John Bowring). W. Tait, 1843 (első megjelenés: 1820)

Bhagwat, Ashutosh: Purpose Scrutiny in Constitutional Analysis. 85 California Law Review 2971997

Bhagwhat, Ashutosh: The Test That Ate Everything: Intermediate Scrutiny in First Amendment Jurisprudence. 2007 University of Illinois Law Review 7832007

BLASI, Vincent: The Checking Value in First Amendment Theory. American Bar Foundation Research Journal Vol. 2, 1977/3

BogDANDY, Armin von: A nemzeti jogtudomány az európai jogi térségben. Kiáltvány. In: JAKAB András - MENYHÁRD Attila (szerk.): A jog tudománya. Tudománytörténeti és tudományelméleti írások, gyakorlati tanácsokkal. Budapest, HVG-ORAC, 2015

BOLLINGER, Lee C.: The tolerant society. New York-Oxford, Oxford University Press, 1986

BORK, Robert H.: Neutral Principles and Some First Amendment Problems. 1 Indiana Law Journal 1971

Chemerinsky, Erwin: Constitutional Law - Principles and Policies. New York, Aspen Publisher, 2006 
CSEPORÁN Zsolt: A müvészet szabadságával élö személyek alapjogi helyzete Magyarországon. In: Kocsis Miklós - TILK Péter (szerk.): A müvészet szabadsága alkotmányjogi megközelítésben. Kodifikátor Alapítvány, Pécs, 2013

DUPRÉ, Catherine: Importing the Law in Post-Communist Transitions. The Hungarian Constitutional Court and the Right to Human Dignity. Oxford-Portland Oregon, Hart Publishing, 2003

DwORKIN, Ronald: Freedom's Law. The moral reading of the American constitution. Oxford University Press, 1996

DwORKIN, Ronald: Taking Rights Seriously. Cambridge, Mass., Harvard University Press, 1977

DWORKIN, Ronald: Is There a Right to Pornography? 1 Oxford Journal of Legal Studies 1771981

Ely, John Hart: Flag Desecration: a Case Study in the Roles of Categorization and Balancing in First Amendment Analysis. 88 Harvard Law Review 1482 1974-1975

ESSUNGER, Henrik: Stoic listeners? Speech Harms and the First Amendment. 6 Journal of Law and Social Change 552002

FISS, Owen M.: Liberalism Divided: Freedom of Speech and the Many Uses of State Power. Boulder, Westview Press, 1996

FrANTZ, Laurent B.: The First Amendment in the Balance. 71 Yale Law Journal 1424 1961-1962

FrANTZ, Laurent B.: Is The First Amendment Law? - A Reply to Professor Mendelson. 51 California Law Review 7291963

GELLÉN Klára: A kereskedelmi kommunikáció szabályozása. In: KolTAY András NYAKAS Levente (szerk.): Magyar és európai médiajog (Budapest, Complex, 2012)

GYŐRFI Tamás: Az alkotmánybíráskodás politikai karaktere. Értekezés a magyar Alkotmánybíróság első tíz évéről. INDOK, Budapest, 2001

HABERMAS, Jürgen: A társadalmi nyilvánosság szerkezetváltozása. Budapest, Osiris, 1999

HALmai Gábor: A véleményszabadság határai. Budapest, Atlantisz, 1994

HALMAI Gábor - TóTH Gábor Attila: Emberi jogok. Budapest, Osiris, 2003

HALMAI Gábor: Hátramenetben az alapjogvédelem? Fundamentum 2000/3.

HALMAI Gábor: Túl kevés és túl sok szólásszabadság. Fundamentum 2005/3.

HANÁK András: Meddig nyújtózkodhat a magyar szólásszabadság? Amicus curiae az Alkotmánybíróság elött folyamatban lévö ügyben. Fundamentum 2001/2.

HANÁK András: Szent szólásszabadság. Fundamentum 2009/4. 
HÖRCHERNÉ MAROSI Ildikó - KoRMÁNYOS Zoltán: Az Alkotmánybiróságnak a Fövárosi Közigazgatási és Munkaügyi Bíróság piacfelügyeleti bírsággal kapcsolatos ügyben hozott itéletét megsemmisitö döntése. Jogesetek Magyarázata 2015/3.

Jackson, Thomas H. - JefFries, John Calvin: Commercial Speech: Economic Due Process and the First Amendment. 65 Virginia Law Review 1

KALVEn, Harry: Metaphysics of the Law of Obscenity. 1960 Supreme Court Review 1

Kalven, Harry: The New York Times Case: A Note on „, The Central Meaning of the First Amendment”. 1964 Supreme Court Review 191

KALVEN, Harry: Upon Rereading Mr. Justice Black on The First Amendment. 14 UCLA Law Review 428 1966-1967

Kalven, Harry: The Concept of the Public Forum: Cox v. Louisiana. 1965 Supreme Court Review 1

KIS János: Alkotmányos demokrácia. Három tanulmány. Budapest, INDOK, 2000

KolTAy András: A szólásszabadság alapvonalai. Budapest, Századvég, 2009

Koltay András: A véleménynyilvánitás szabadsága. Fogalmi tisztázás az Alkotmány 61. §ához. Századvég 2008/2.

KoltAY András: A szólásszabadság igazolásai az angolszász jog és jogfilozófia fényében. Valóság 2007/9.

KolTAY András: A közéleti szereplök hírnévvédelme a strasbourgi Emberi Jogok Európai Bíróságának gyakorlatában. Jogtudományi Közlöny 2008/2.

Koltay András: A „clear and present danger” elv fordulatos története az Egyesült Államokban és Magyarországon. Magyar Jog 2009/7. sz.

Koltay András: Dorian Gray képmásához való joga: a müvészet szabadságának önálló alapjogi jellegéről. In: KOLTAY András - TÖRÖK Bernát (szerk.): Sajtószabadság és médiajog a 21. század elején 3. Budapest, Wolters Kluwer, 2016

LEGRAND, Pierre: European legal systems are not converging. 45 International and Comparative Law Quarterly 521996

LENKOVICS Barnabás: Ptk. és Alkotmány, ember- és társadalomkép. Alkotmánybírósági Szemle 2011/2.

LiCHTENBERG, Judith: Foundations and limits of freedom of the press. In: Uö. (szerk.): Democracy and the mass media. Cambridge, Cambridge University Press, 1990

MAJTÉNYI László: Az információs szabadságok. Budapest, Complex, 2006

MAJTÉNYI László: Az ORTT szabadságjog-védelmi szerepéről. Fundamentum 2010/2.

MAJTÉNYI László - POLYÁK Gábor: A szabadság hazai hagyományának megtagadása - új médiatörvények Magyarországon. Közjogi Szemle 2011/1.

McDonald, Barry P.: Speech and Distrust: Rethinking the Content Approach to Protecting the Freedom of Expression. 81 Notre Dame Law Review 1347 2005-2006 
MeIKLEJohn, Alexander : Free Speech and Its Relation to Self-Government. New York, Harper Bros., 1948

MeIKLEJohn, Alexander: The First Amendment is an Absolute. Supreme Court Review 1961

Meiklejohn, Alexander: What Does the First Amendment Mean? 20 The University of Chicago Law Review 461 1952-1953

Mendelson, Wallace: On the Meaning of the First Amendment: Absolutes in the Balance. 50 California Law Review 8211962

Mendelson, Wallace: The First Amendment and the Judicial Process: A Reply to Mr. Frantz. 17 Vanderbilt Law Review 479 1963-1964

MiLL, John Stuart: A szabadságról. Budapest, Századvég, 1994

MiLl, James: Liberty of the press. In: Uö: Essays on government, jurisprudence, liberty of the press and law of nations. Augustus M. Kelley Publishers, 1986 (első megjelenés: 1811)

MiLton, JoHn: Milton, az angol forradalom tükre. Budapest, Gondolat, 1975

MolnÁR Péter: Gondolatbátorság. Szólásszabadság és közbeszélgetés az Egyesült Államokban és Magyarországon. Budapest, Új Mandátum, 2002

MOLNÁR Péter: Az alkotmányos mérce világosabb értelmezése felé. Fundamentum 2004/1. sz.

Nimmer, Melville B.: The Right to Speak from Times to Time: First Amendment Theory Applied to Libel and Misapplied to Privacy. 56 California Law Review 935 1968

PACZOLAY Péter: Alkotmánybíráskodás. Alkotmányértelmezés. Jogfilozófiák sorozat, Budapest, 1995

PACZOLAY Péter: Az Alkotmánybíróság új hatásköreiröl egy év elteltével. Alkotmánybírósági Szemle 2013/1.

PACZOLAY Péter: Az Alkotmánybiróság alkotmányvédő szerepéről. Alkotmánybírósági Szemle 2014/1.

POLYÁK Gábor: Új média, régi kérdések? A digitális átállás alkotmányjogi vonatkozásai. Fundamentum 2007/2.

Post, Robert C.: Participatory Democracy as a Theory of Free Speech. 97 Virginia Law Review 477

Post, Robert C.: Recuperating First Amendment Doctrine. 47 Stanford Law Review 1249 1994-1995

Post, Robert C.: Democracy, Expertise, Academic Freedom. A First Amendment Jurisprudence for the Modern State. New Haven, Yale University Press, 2013 
Post, Robert C.: The Constitutional Status of Commercial Speech. 48 UCLA Law Review 1 2000-2001

Post, Robert C.: Reconciling Theory and Doctrine in First Amendment Jurisprudence. 88 California Law Review 2355

Post, Robert C.: Viewpoint Discrimination and Commercial Speech. 41 Loyola of Los Angeles Law Review 169 2007-2008

Post, Robert C.: The Constitutional Concept of Public Discourse: Outrageous Opinion, Democratic Deliberation, and Hustler Magazine v. Falwell. 103 Harvard Law Review 601 1989-1990

Post, Robert C.: Blasphemy, the First Amendment and the Concept of Intrinsic Harm. 8 Tel Aviv University Studies in Law 2931988

Post, Robert C.: Cultural Heterogeneity and Law: Pornography, Blasphemy, and the First Amendment. 76 California Law Review 2971988

Post, Robert C.: Racist speech, Democracy, and the First Amendment. 32 William and Mary Law Review 267 1990-1991

Post, Robert C.: Meiklejohn's Mistake: Individual Autonomy and the Reform of Public Discourse. 64 University of Colorado Law Review 11091993

POZSÁR-SZENTMIKLÓSY Zoltán: Alapjogok mérlegen. Az általános alapjogi teszt dogmatikája. HVG-ORAC, Budapest, 2016

RAZ, Joseph: Free expression and personal identification. Oxford Journal of Legal Studies (1991 Autumn)

REDISH, Martin R.: The First Amendment in the Marketplace: Commercial speech and the Values of Free Expression. 39 George Washington Law Review 4291971

Redish, Martin H.: Freedom of Expression. A Critical Analysis. Charlottesville, The Michie Company, 1984

ReDISH, Martin H.: The Content Distinction in First Amendment Analysis. 34 Stanford Law Review 113 1981-1982

Redish, Martin H.: The Value of Free Speech. University of Pennsylvania Law Review, 1982

REDISH, Martin H.: The Adversary First Amendment. Free Expression and the Foundations of American Democracy. Stanford Univerity Press, 2013

ReDISH, Martin H.: Tobacco Advertising and the First Amendment. Iowa Law Review, Vol. 81., No. 3., 1996

SADURSKI, Wojciech: Freedom of speech and its limits. Boston, Kluwer Academic Publishers, 1999

SAJÓ András: A szólásszabadság kézikönyve. Budapest, MTA Állam- és Jogtudományi Intézet, 2005 
SAJÓ András: A liberális jog sorsa Magyarországon: a szólásszabadság kalandjai 1989 után. Jogtudományi Közlöny 2006/10.

SAJÓ András: (Ön)cenzort akarunk! Élet és Irodalom L. évfolyam 14. szám, 2006. április 7.

SARTORI, Giovanni: Demokrácia. Budapest, Osiris, 1999

SCANLON, Thomas: A theory of freedom of expression. Philosophy and Public Affairs, Vol. 1. No. 2. (Winter 1972)

SCHAUER, Frederick: Categories and the First Amendment: A Play in Three Acts. 34 Vanderbilt Law Review 265

SCHAUER, Frederick: Must Speech be Special? 78 Northwestern University Law Review 1290

SCHAUER, Frederick: Freedom of Speech: a Philosophical Enquiry. Cambridge, Cambridge University Press, 1982

SCHAUER, Frederick: The Phenomenology of Speech and Harm. Ethics, Vol. 103, No. 4 (July, 1993)

SCHAUER, Frederick: Harm(s) and the First Amendment. 2011 The Supreme Court Review 812011

SCHAUER, Frederick: Cuban Cigars, Cuban Books, and the Problem of Incidental Restrictions on Communications. 26 William and Mary Law Review 779 1984-1985

SCHAUER, Frederick: On the relationship between press law and press content. In: Timothy CoOK (szerk.): Freeing the presses: The First Amendment in action. Baton Rouge, Louisiana State University Press, 2005

SHIFFRIN, Steven: Defamatory Non-media Speech and First Amendment Methodology. 25 UCLA Law Review 915 1977-1978

SHIFFrin, Steven: Defamatory Non-media Speech and First Amendment Methodology. 25 UCLA Law Review 915 1977-1978

SMUK Péter: A demokratikus politikai diskurzus alkotmányos garanciái és gyakorlata Közép-Kelet-Európában. In: KOLTAY András - TÖRÖK Bernát (szerk.): Sajtószabadság és médiajog a 21. század elején. Budapest, Wolters Kluwer, 2014

SMUK Péter: A demokratikus politikai diskurzus alkotmányos garanciái - délkelet-és kelet-európai kihívások. In: KOLTAY András - TÖRÖK Bernát (szerk.): Sajtószabadság és médiajog a 21. század elején 2. Budapest, Wolters Kluwer, 2015

SONNEVEND Pál: Alapvetö jogaink a csatlakozás után. Fundamentum 2003/2.

Sólyom László: Az alkotmánybíráskodás kezdetei Magyarországon. Budapest, Osiris, 2001 
SÓLYOM László: Kölcsönhatás az Emberi Jogok Európai Bíróságának esetjoga és a szólásszabadság védelme között Magyarországon. Állam- és Jogtudomány 1996-97/34.

SÓLYOM László: A „nehéz eseteknél” a biró erkölcsi felfogása jut szerephez - Sólyom Lászlóval, az Alkotmánybiróság elnökével Tóth Gábor Attila beszélget. Fundamentum 1997/1.

Sólyom László: Szeretetbeszéd, tiszteletbeszéd. Népszabadság, 2001. december 24.

Sólyom Péter: A müvészet szabadsága és az esztétikai itéletek. Iustum Aequum Salutare 2007/2.

Stone, Geoffrey R.: Content Regulation and the First Amendment. 25 William and Mary Law Review 189 1983-1984

Stone - SeIDmAn - Sunstein - Tushnet - Karlan: The First Amendment (Fifth Edition). New York, Wolters Kluwer, 2016

Sunstein, Cass R.: Democracy and the Problem of Free Speech. New York, Free Press, 1995

SzABÓ Máté Dániel: Nyilvános magánszféra - hol a határ? In: Ünnepi kötet Sári János egyetemi tanár 70. születésnapja tiszteletére. Budapest, Rejtjel Kiadó, 2008

SzABÓ Miklós - JAKAB András: A jogdogmatikai kutatás. In: JAKAB András MENYHÁRD Attila (szerk.): A jog tudománya. Tudománytörténeti és tudományelméleti írások, gyakorlati tanácsokkal. Budapest, HVG-ORAC, 2015. 52.

SZENTE Zoltán: Emberi jogok-e a parlamenti képviselői jogok? A képviselöi szólásszabadság alkotmányjogi jellegéröl. Állam- és jogtudomány 2015/2.

TILK Péter: A kifejezési szabadság és a gyülöletbeszéd néhány alkotmányjogi vonatkozása. Acta Humana 2005/1.

TILK Péter: A müvészet szabadságának szabályozási modellje az Alaptörvényben. In: Kocsis Miklós - TILK Péter (szerk.): A müvészet szabadsága - alkotmányjogi megközelitésben. Kodifikátor Alapítvány, Pécs, 2013

Thomson, Judith Jarvis: The Realm of Rights. Cambridge-London, Harvard University Press, 1990

Tо́тн J. Zoltán: Az önkényuralmi jelképek használata mint a véleménynyilvánítási szabadság korlátja? (A 4/2013. AB határozat elözményei, indokai és következményei, valamint az új Btk.-szabályozás pozitívumai és fogyatékosságai). Jogelméleti Szemle $2013 / 2$.

Tо́тн J. Zoltán: A defamatorikus deliktumokkal kapcsolatos részes állami büntetőbírósági döntések megitélése a strasbourgi bíróság gyakorlatában. In: KOLTAY András - TÖRÖK Bernát (szerk.): Sajtószabadság és médiajog a 21. század elején 4. Wolters Kluwer, Budapest, 2017 
Tо́тн Gábor Attila: Túl a szövegen. Értekezés a magyar alkotmányról. Budapest, Osiris, 2009

TóтH Gábor Attila: A szólás méltósága. Századvég 2008/2.

Tóтн Gábor Attila: Szólásszabadság és befogadó társadalom. Pro Futuro 2014/1.

TÖRÖK Bernát: A gyülöletbeszéd tilalmának médiajogi mércéi. Jogtudományi Közlöny 2013/2.

TÖRÖK Bernát: A közlések alkotmányos alapértéke a szólásszabadság magyar koncepciójában. In: KOLTAY András - TÖRÖK Bernát (szerk.): Sajtószabadság és médiajog a 21. század elején 2. Wolters Kluwer, Budapest, 2015

TÖRÖK Bernát: Védhetjük-e a vallás(os)okat a blaszfémiától? In: KOLTAY András TÖRÖK Bernát (szerk.): Sajtószabadság és médiajog a 21. század elején. Budapest, Wolters Kluwer, 2014

TÖRÖK Bernát: Alkotmányjogi tesztek hálójában. A sajtószabadság esete a tőkepiaccal. In: FEJES Zsuzsanna - TÖRÖK Bernát (szerk.): „SUUM CUIQUE - Ünnepi tanulmányok Paczolay Péter 60. születésnapja tiszteletére”. Pólay Elemér Alapítvány, Szeged, 2016

TÖRÖK Bernát: A politikai reklámozás magyar szabályozásáról. Érvek a médiakampány nagyobb szabadsága mellett. In: Cserny Ákos (szerk.): Választási dilemmák. Budapest, Nemzeti Közszolgálati Egyetem, 2015

Tribe, Laurence H.: American Constitutional Law. Mineola, NY, The Foundation Press, 1978

UDVARY Sándor: Alkotmányos médiajog? Az elektronikus média jogának elemzése az amerikai és a magyar alkotmánybiráskodási gyakorlat tükrében. Budapest, Károli Gáspár Református Egyetem Állam- és Jogtudományi Kar, 2008

UDVARY Sándor: Citizens United - Nem európainak való vidék. A társaságok független részvétele a politikai kampányokban. In Medias Res 2012/2.

Williams, Susan H.: Content Discrimination and the First Amendment. 139 University of Pennsylvania Law Review 615 1990-1991

Wright, R. George: Speech on Matters of Public Interest and Concern. 37 DePaul Law Review 27 1987-1988

Wright, R. George: Content-based and Content-neutral Regulation of Speech: the Limitations of a Common Distinction. 60 University of Miami Law Review 333 20052006

ZELler Judit: A tudomány és a müvészet szabadsága. In: CHRONOWSKI Nóra Drinóczi Tímea - Petrétei József - TILK Péter - ZELler Judit: Magyar Alkotmányjog III. - Alapvető jogok. Dialóg Campus, Budapest-Pécs, 2006 


\section{Elemzett alkotmánybírósági határozatok}

23/1990. (X. 31.) AB határozat

30/1992. (V. 26.) AB határozat

37/1992. (VI. 10.) AB határozat

36/1994. (VI. 24.) AB határozat

24/1996. (VI. 25.) AB határozat

1270/B/1997. AB határozat

33/1998. (VI. 25.) AB határozat

12/1999. (V. 21.) AB határozat

13/2000. (V. 12.) AB határozat

14/2000. (V. 12.) AB határozat

18/2000. (VI. 6.) AB határozat

55/2001. (XI. 29.) AB határozat

57/2001. (XII. 5.) AB határozat

1006/B/2001. AB határozat

18/2004. (V. 25.) AB határozat

75/2008. (V. 29.) AB határozat

95/2008. (VII. 3.) AB határozat

96/2008. (VII. 3.) AB határozat

23/2010. (III. 4.) AB határozat

165/2011. (XII. 21.) AB határozat

1/2013. (I. 7.) AB határozat

4/2013. (II. 21.) AB határozat

16/2013. (VI. 20.) AB határozat

3206/2013. (XI. 18.) AB határozat

3207/2013. (XI. 18.) AB határozat 
3208/2013. (XI. 18.) AB határozat

7/2014. (III. 7.) AB határozat

13/2014. (IV. 18.) AB határozat

18/2014. (V. 30.) AB határozat

19/2014. (V. 30) AB határozat

28/2014. (IX. 29.) AB határozat

3/2015. (II. 2.) AB határozat

5/2015.(II. 5.) AB határozat

9/2015. (IV. 23.) AB határozat

14/2016. (VII. 18.) AB határozat

3264/2016. (XII. 14.) AB határozat

14/2017. (VI. 30.) AB határozat

3328/2017. (XII. 8.) AB határozat

34/2017. (XII. 11.) AB határozat

3001/2018. (I. 10.) AB határozat 